$$
\begin{aligned}
& \text { UNIVERSIDADE DE SÃO PAULO } \\
& \text { INSTITUTO DE GEOCIÊNCIAS }
\end{aligned}
$$

\title{
DEFINIÇÃO DAS TRAJETÓRIAS P-T-t EM ROCHAS METAMÓRFICAS DO FLANCO OCIDENTAL DA CORDILHEIRA CENTRAL DA COLÔMBIA, NAS REGIÕES DE CALDAS E EL RETIRO
}

Andrés Bustamante Londoño

Orientador: Prof. Dr. Caetano Juliani

DISSERTAÇÃO DE MESTRADO

Programa de Pós-Graduação em Mineralogia e Petrologia

SÃO PAULO

2003 


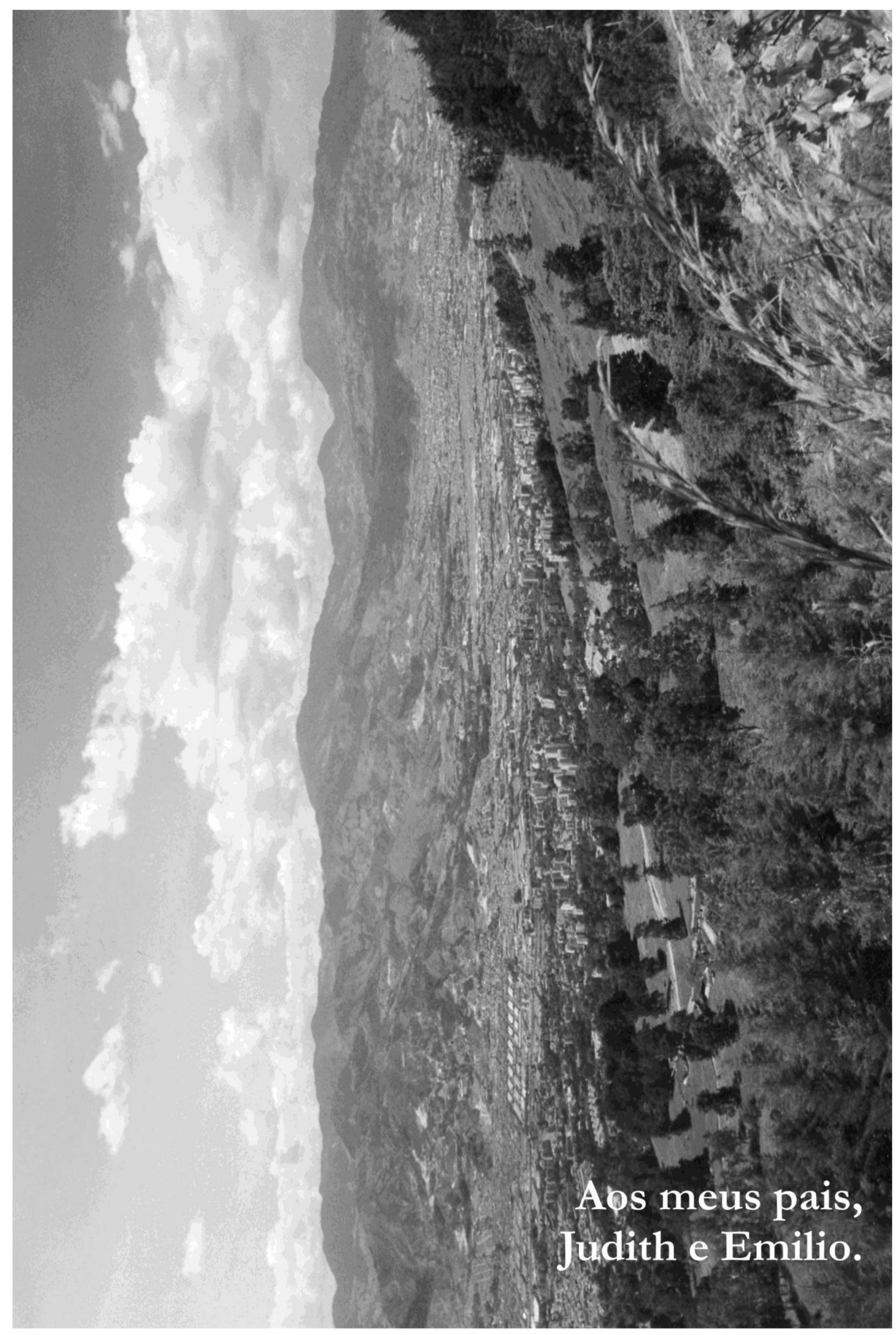


Clearly our vision suffers from myopia; objectivity is always tainted by available concepts. 
Ao Professor Doutor Caetano Juliani, quem além de proporcionar sua desinteressada amizade, acreditar no meu trabalho, oferecer seus apropriados conselhos e sua orientação impecável na elaboração do trabalho.

Ao Emilio Bustamante Quintero e Alfredo Londoño Velásquez, porque sem eles não teria existido a possibilidade de realizar a viagem para o Brasil nem o trabalho de campo.

À CNPq pela bolsa de mestrado.

Ao Agustín Cardona Molina e Marcela Marulanda Vélez por tudo seu apoio desde antes de chegar ao Brasil e por o tempo tudo da amizade, além das valiosas ajudas na elaboração deste trabalho.

À Profa. Dra. Marion B.I. Weber Scharff, quem em parte foi a inspiração para a realização do trabalho em esta área e peça fundamental no trabalho de campo, além de ter facilitado algumas das amostras aqui analisadas.

Ao Paul Duhart O., amigo de varias aventuras e pela disposição para ajudar no geológico e no cotidiano.

Ao filósofo Vladimir de Oliva Mota e sua esposa, a lingüista Christine Arndt, assim como o sociólogo Rafael dos Santos Molinari, pelas extensas conversações sobre filosofia, política e as partidas de xadrez.

À Thatyana Benevides, pela amizade e pela ajuda continua no tratamento dos dados e do uso dos programas e equações de termobarometria.

No departamento de Geologia da Universidade Eafit, foi sempre apoiado pelos docentes, e principalmente pelas professoras Dra. Gloria Toro Villegas e MSc. Gloria Sierra Lopera e o chefe do departamento o professor MSc. Geovanny Bedoya Sanmiguel. Também aos funcionários dos laboratórios de geologia Maria Isabel Acevedo e Wilton Echavarria. Com todos eles fico muito grato pela disposição e a prestabilidade na hora de fazer meu trabalho de campo e do tratamento das amostras.

Aos Professores Doutores do Instituto de Geociências Valdecir de Assis Janasi, Silvio Roberto Farias Vlach, Gergely Andrés Julio Szabó, Fábio Ramos Dias de Andrade, pela ajuda constante no transcurso da pesquisa.

No trabalho de campo tive a colaboração imprescindível da Dra. Annabel Pérez Aguilar, do geólogo Pablo A. Castro López e dos futuros geólogos Carolina Peláez Mejía, Camilo Bustamante Londoño, José Fernando Duque e Luis Fernando Montes. 
Agradeço também aos meus colegas da pós-graduação César Vinasco, Fernando Camargo Freitas, Lucelene Martins, lede Zolinger, Fernando Pelegrini Spinelli, Rafael Hernandes, Klaus Juergen Petersen, Paulo César Corrêa da Costa, Gaston Eduardo E. Rojas, Cíntia Maria G. da Silva. Todos eles contribuíram de uma ou outra forma para a elaboração desta pesquisa.

Aos funcionários do Instituto de Geociências, Ana Paula Cabanal, Magali Poli Fernandes Rizzo, Angélica, Marcos Monsueto, Luiz Mogueira, Paulo Morgato, Cláudio Hoop, Paulo Molinaro, Tadeu, Dalton, Edemir, Henrique, Claudionor.

Fico com imensa gratidão com todas essas pessoas que fazem da vida no instituto e no dia a dia uma boa razão para continuar compartilhando o devenir. 
Apesar da existência de vários estudos geológicos detalhados no segmento norte do Andes, muitos aspectos estão ainda por serem resolvidos, principalmente aqueles concernentes ao tipo, grau e evolução metamórfica, ambiente tectônico de formação e correlação com margem paleozóica do continente Gondwana e com os terrenos mesozóicos oceânicos.

A Cordilheira Central dos Andes Colombianos, é representada por um complexo polimetamórfico com magmatismo associado e uma fina pilha de sedimentos suprajacente em algumas partes da cordilheira. $O$ embasamento desta cordilheira é principalmente composto por rochas metamórficas e por isto a sua compreensão deve ser feita a partir do entendimento dos processos de metamorfismo que afetaram a área.

$\mathrm{Na}$ Cordilheira Central, a caracterização dos distintos processos geológicos, tem sido interpretada em termos de eventos orogênicos em escala regional, pelo que muitas incongruências são percebidas na aplicação dos diferentes modelos e o análise detalhado da evolução metamórfica permitiria separar os diferentes eventos e a possibilidade de reconstruir as condições de pressão e temperatura (P-T) da crosta, podendo definir a natureza do ambiente tectônico assim como a relação entre as unidades.

Nos arredores da cidade de Medellín (municípios de Caldas e El Retiro) afloram rochas metamórficas com protólitos básicos e pelíticos (Anfibólio Xistos de Caldas e Xistos de Ancón), com alguns aportes de material granítico, às vezes metamorfisado (Gnaisse de La Miel). Outro conjunto de rochas metabásicas e metapelíticas associadas apresenta-se ao oriente destas unidades. Este conjunto de rochas é nomeado Anfibolitos, Migmatitos e Granulitos de El Retiro.

A termobarometria nos Anfibólio Xistos de Caldas indicam condições de pressão e temperatura próprias da facies anfibolito e descrevem uma trajetória em sentido antihorário sem ficar claro o caminho de regresso das condições de retrometamorfismo. As pressões nestas rochas variam entre $\approx 6.3$ e $13.5 \mathrm{~Kb}$ com variações relativamente estreitas da temperatura, com valores que estão entre $\approx 550$ e $630^{\circ} \mathrm{C}$. No caso dos Xistos de Ancón, a trajetória resultante é em sentido anti-horário e reflete aumentos de temperatura evidenciados na petrografia pela presença de sillimanita e o regresso da 
trajetória é pela zona da cianita. As temperaturas neste conjunto variam entre $\approx 400 \mathrm{e}$ $555^{\circ} \mathrm{C}$ para pressões constantes de 5 e $6 \mathrm{~Kb}$ en condições de metamorfismo progressivo. $O$ retrometamorfismo apresenta pressões entre $\approx 7.6$ e $7.2 \mathrm{~Kb} \mathrm{com}$ temperaturas $\approx 645$ e $635^{\circ} \mathrm{C}$, além de temperaturas entre $\approx 500$ e $600^{\circ} \mathrm{C}$ com pressão constante de $6 \mathrm{~Kb}$. No conjunto de rochas de El Retiro, apresenta-se uma forte descompressão com variações estreitas no campo da temperatura, apresentando valores de pressão entre $\approx 8.7$ e $2.7 \mathrm{~Kb}$ com variação na temperatura de $\approx 740$ e $633^{\circ} \mathrm{C}$.

As unidades conhecidas como Anfibólio Xistos de Caldas, Xistos de Ancón e Gnaisse de La Miel, evidenciam uma historia metamórfica comum de processos de tipo colisional. Os Anfibólio Xistos de Caldas e os Xistos de Ancón poderiam representam fragmentos de crosta oceânica com sedimentos pelíticos intercalados, a qual foi exumada, além de ter um corpo metagranítico relacionado (Gnaisse de La Miel) cuja geoquímica evidencia seu caráter colisional. Este corpo granítico pode ser o resultado do metamorfismo ou do processo de exumação que afetou a região e gerou o pacote de xistos ou pelo menos começou fazer parte da história geológica da área logo depois da formação dos xistos. As rochas de El Retiro (Anfibolitos, Migmatitos e Granulitos de El Retiro) sugerem que seja um bloco que colidiu com as de Caldas (Anfibólio Xistos de Caldas, Xistos de Ancón e Gnaisse de La Miel) e a partir de então têm uma história conjunta, no mínimo, a partir do Triássico, como é indicado pela geocronologia e pela ausência de estruturas regionais entre estas unidades. Finalmente um possível processo de rifteamento que da origem a pontos restritos de calor e que geram as rochas em facies granulito, assim como estruturas de cisalhamento mais marcadas em alguns litotipos. 
In spite of the existence of several detailed geological studies in the northern segment of the Andes Cordillera, many aspects are still to be resolved, mainly those concerning the type, grade and metamorphic evolution, tectonic setting formation and correlation with the Palaeozoic margin of Gondwana and with Mesozoic oceanic terranes.

The Central Cordillera is represented by a polimetamorphic complex with associated magmatism, and a thin pile of cover sediments in some parts of the mountain range. The basement of the Central Cordillera is mainly constituted by metamorphic rocks and for that its comprehension should be done from the understanding of the metamorphism that affected the area.

In the Central Cordillera, the characterization of the different geological processes has been interpreted in terms of orogenic events in regional scale, however, a lot of incongruities are perceived in the application of the different models, and the detailed analysis from the metamorphic evolution would permit the separation distinct events and the reconstruction possibility of the crust's pressure and temperature $(P-T)$ conditions, being able to define the nature of the tectonic setting, as well as the relation among the units.

In the surroundings of the city of Medellin (Caldas and El Retiro cities) occur metamorphic rocks with basic and pelitic protolites (Amphibole Schist of Caldas and Schists of Ancón), with some contributions of granitic material, sometimes affected by metamorphic processes (Gneiss of La Miel). Another group of metabasic and metapelitic rocks associated is observed to the east of these units. This group is named Amphibolites, Migmatites and Granulites of El Retiro.

The group Amphibole Schist of Caldas and Schists of Ancón could be formed in an distal environment and under reduct conditions and later inserted to the continent by a possible subduction zone. El Retiro rocks could be correspond to the continental basement of the area and it leaves of them it can correspond to impure sediments, of continental margin, formed under high grade metamorphic conditions. The metamorphism in these last rocks was more intense, originating the rocks in the granulite facies in portions of the crust in which the partial pressure of $\mathrm{H}_{2} \mathrm{O}$ was relatively lowers, as well as of migmatites, result of the anatexis of quartz-feldspatic 
composition rocks, in places which the partial pressure of $\mathrm{H}_{2} \mathrm{O}$ was higher. This metamorphism was accompanied of intense deformation, which to have juxtaposed both migmatites and granulites blocks. Therefore later there was intense interaction fluid-rock, as well as restricted points of heat caused by igneous intrusions and that are responsible for the variations in the size of grain of the minerals and especially by the fortress retrometamorphic reequilibrium and by the fluids transport.

Thermobarometric data in Amphibole Schist of Caldas indicate pressure and temperature conditions of the amphibolite facies and they describe a counterclockwise path, with no precise retrometamorphic P-T-t trajectory. The pressures in these rocks vary between $\approx 6.3$ and $13.5 \mathrm{~Kb}$ with narrow variations of the temperature, with values between $\approx 550$ and $630^{\circ} \mathrm{C}$. In the case of the Schists of Ancón, the result is a counterclockwise path and it reflects increases of temperature evidenced by the occurence of sillimanite and the return of the path to the kyanite zone (amphibolite facies). The temperatures in this group vary between $\approx 400$ and $555^{\circ} \mathrm{C}$ for constant pressures of 5 and $6 K b$ in prograde metamorphic conditions. The retrometamorphism presents pressures between $\approx 7.6$ and $7.2 \mathrm{~Kb}$ with temperatures aproximately between $\approx 645$ and $635^{\circ} \mathrm{C}$, besides temperatures between $\approx 500$ and $600^{\circ} \mathrm{C}$ with constant pressure of $6 \mathrm{~Kb}$. The El Retiro set presents a strong decompression with narrow variations in the temperature field, showing pressure values between $\approx 8.7$ and $2.7 \mathrm{~Kb}$ with temperatures of $\approx 740$ and $633^{\circ} \mathrm{C}$. 
INTRODUÇÃO

1 OBJETIVOS 2

2 MATERIAIS E MÉTODOS 2

2.1 Levantamentos bibliográficos $\quad 2$

2.2 Levantamentos de campo e amostragem 2

2.3 Petrografia $\quad 3$

2.4 Química mineral $\quad 3$

2.5 Geotermobarometria $\quad 4$

3 LOCALIZAÇÃO DA ÁREA DE ESTUDO 5

4 CONTEXTO GEOLÓGICO REGIONAL $\quad 6$

5 GEOLOGIA LOCAL $\quad 14$

5.1 Anfibólio Xistos de Caldas $\quad 14$

$\begin{array}{ll}5.2 \text { Xistos de Ancón } & 18\end{array}$

5.3 Gnaisse de La Miel $\quad 20$

5.4 Anfibolitos, Migmatitos e Granulitos de El Retiro 22

6 PETROGRAFIA $\quad 25$

6.1 Anfibólio Xistos de Caldas $\quad 25$

6.2 Xistos de Ancón $\quad 31$

6.3 Gnaisse de La Miel 38

6.4 Anfibolitos, Migmatitos e Granulitos de El Retiro 39

7 QUÍMICA MINERAL $\quad 49$

7.1 Anfibólio Xistos de Caldas $\quad 49$

7.2 Xistos de Ancón $\quad 56$

7.3 Anfibolitos, Migmatitos e Granulitos de El Retiro

8 GEOTERMOBAROMETRIA: APLICAÇÃO, CONCEITOS E CALIBRAÇÕES $\mathbf{6 8}$

8.1 Geotermobarômetros Internamente Consistentes 71

8.2 Geotermômetro Granada(Grt)-Clorita(Chl) 71

8.3 Geotermômetro Estaurolita(St)-Granada(Grt) 72

8.4 Geotermômetro Cloritóide(Cld)-Clorita(Chl) $\quad 72$

9 CÁLCULOS GEOTERMOBAROMÉTRICOS

9.1 Anfibólio Xistos de Caldas $\quad 73$

9.1.1 Amostras 11c e 12c $\quad 73$

9.1.2 Amostra 20b $\quad 80$

9.2 Xistos de Ancón $\quad 84$

9.2.1 Amostra 45b $\quad 84$

9.2.2 Amostra $46 \quad 86$

9.3 Anfibolitos, Migmatitos e Granulitos de El Retiro 89

9.3.1 Amostra 32d 90

9.3.2 Amostra $53 \quad 91$

DISCUSSÃO $\quad 93$

REFERÊNCIAS BIBLIOGRÁFICAS $\quad 103$

$\begin{array}{ll}\text { ANEXOS } & 107\end{array}$

Tabela de minerais presentes nas diferentes amostras de migmatitos.

Tabelas de análises químicas.

Tabelas mostrando as associações e respectivas análises usadas nos cálculos termobarométricos realizados utilizando-se o software twq. 
A Cordilheira dos Andes na Colômbia subdivide-se nas cordilheiras Oriental, Central e Ocidental, formadas por eventos de acresção crustal distintos. A Cordilheira Oriental é composta por uma espessa pilha de metassedimentos pouco deformados e de grau metamórfico muito baixo que, recobrem discordantemente o embasamento Pré-cambriano. A Cordilheira Ocidental é constituída por terrenos oceânicos acrescidos à crosta continental e a Cordilheira Central é formada, em essência, pelo embasamento metamórfico, com rochas magmáticas associadas, e delgadas camadas de sedimentos de ocorrência local.

Apesar da existência de muitos estudos nesta região, são ainda necessários, para melhor compreensão da evolução geológica e para o estabelecimento dos modelos tectônicos, detalhamentos sobre a evolução metamórfica, geologia estrutural, geocronologia, geoquímica e granito-gênese.

Os estudos metamórficos, especialmente aqueles baseados na geotermobarometria e na microestrutural, são essenciais para o entendimento dos processos de instalação de uma anomalia térmica e da recomposição das isotermas, bem como dos processos tectônicos vinculados com a subducção e a exumação das rochas em cinturões orogenéticos. Assim, os estudos aqui apresentados, visam contribuir para o estabelecimento das condições metamórficas que afetaram as rochas da região de Caldas e El Retiro, pertencentes ao embasamento da Cordilheira Central dos Andes do Norte na Colômbia. Estes estudos permitiram a definição de um modelo de evolução tectono-metamórfica compatíveis com os dados geocronológicos, bem como com as características geoquímicas de alguns corpos graníticos relacionados às rochas metamórficas.

Uma vez que as rochas metamórficas que afloram nos arredores da cidade de Medellín (cidades de Caldas e El Retiro) tem sido objeto de várias pesquisas de caráter regional, o nível de detalhe dos estudos petrográficos, de química mineral e geotermobarometria realizados nesta pesquisa, constituem-se em um bom guia para estudos complementares e para revisar a documentação existente. 


\section{OBJETIVOS}

Esta pesquisa objetivou a caracterização petrográfica do tipo e grau de metamorfismo e a quantificação das condições P-T (pressão-temperatura) do metamorfismo que afetou metassedimentos, anfibolitos, gnaisses e granulitos que afloram nos arredores da cidade de Medellín, especialmente nos municípios de Caldas e El Retiro.

Os estudos objetivaram também o estabelecimento da evolução metamórfica das rochas no contexto geodinâmico da Cordilheira Central, dos Andes do Norte da Colômbia, com base em estudos geotermobarométricos e microestruturais.

\section{MATERIAIS E MÉTODOS}

Para alcançarem-se os objetivos propostos foram utilizados os seguintes materiais e métodos:

\subsection{Levantamentos bibliográficos}

Para a elaboração da dissertação foram usados principalmente o acervo da biblioteca do IGUSP e Trabalhos de Formatura realizados por alunos das universidades Nacional e Eafit de Medellín.

Os levantamentos bibliográficos compreenderam a coleta de informações nas bases de dados fornecidas pelo Sistema Integrado de Bibliotecas da Universidade de São Paulo (SiBi/USP), consultando-se as bases de dados DEDALUS, SciELO, ERL, ProBE e Web of Science.

Estes levantamentos enfocaram estudos sobre a geologia regional, tectônica, metamorfismo e geocronologia dos Andes do Norte, especialmente os feitos nas regiões de Caldas e El Retiro, e estudos geotermobarométricos, notadamente quanto a calibrações de geotermômetros e geobarômetros. Foi também dispensada atenção a publicações sobre aplicação de geotermobarometria e sobre a evolução geológica de terrenos semelhantes aos estudados.

\subsection{Levantamentos de campo e amostragem}

Nos levantamentos em campo foram utilizadas as folhas topográficas 1:25.000 do Instituto Geográfico Agustín Codazzi (IGAC) para localização das amostras e para a escolha dos perfis mais apropriados, incluindo as folhas 146-IV-A, 146-IV-C, 147-III-D, 
167-I-B, 146-II-A, 146-II-B, 147-III-B, 146-II-A e 146-I-B que correspondem a Medellín e arredores.

Foi realizada apenas uma etapa de campo, iniciada por reconhecimento regional das unidades geológicas, posteriormente, foram feitos amostragens sistemáticas mais detalhadas nas diversas unidades geológicas abrangidas nesta pesquisa.

Nestes trabalhos foram descritos 70 afloramentos e coletadas 147 amostras para estudos petrográficos e geotermobarométricos.

\subsection{Petrografia}

As amostras selecionadas foram preparadas na seção de laminação do IGUSP em lâminas de $30 \mu \mathrm{m}$ de espessura, com cobertura, e descritas em microscópio petrográfico de luz transmitida Zeiss Axioplan do Laboratório de Óptica do Departamento de Mineralogia e Geotectônica. Foram confeccionadas e descritas 116 lâminas, das quais 112 pertencem às amostras coletadas no trabalho de campo do projeto e 4 de trabalhos de formatura realizados na área.

As descrições incluíram a definição da composição mineralógica, das texturas metamórficas e reliquiares, das paragêneses, das microestruturas e das relações de blastese dos minerais em relação às foliações metamórficas externas $(\mathrm{Se})$ e internas (Si), o sequenciamento dos eventos deformacionais e a preservação de minerais em domínios microestruturais. Para cada um dos litotipos foram identificados, sempre que possível, o tipo e grau metamórfico, relativamente às foliações metamórficas e aos domínios microestruturais.

A descrição das lâminas foi acompanhada constantemente pelos textos de Spry (1969), Tröger (1979), Nesse (1991), Deer et al. (1992), Hibbard (1995), Passchier \& Trouw (1996).

A aquisição de imagens digitais foi feita com equipamento Olympus Oly-750, com o software ImagePro.

\subsection{Química mineral}

Após estudos petrográficos detalhados foram selecionadas 9 amostras para obtenção das composições químicas dos minerais e sua posterior utilização em cálculos geotermobarométricos. Foram selecionadas 3 amostras de anfibólio xisto, 2 de ortogranulito piroclasítico, 1 de sericita xisto com cloritóide, 1 de biotita-granada xisto, 1 de estaurolita-granada xisto e 1 de migmatito. 
Para as análises em microssonda eletrônica foram confeccionadas lâminas delgadas polidas e metalizadas com película de carbono de $\sim 25 \mathrm{~nm}$ em evaporador Auto 206 da Edwards e as análises foram feitas com a microssonda eletrônica JEOL, modelo JXA 8600 Superprobe no Departamento de Mineralogia e Geotectônica do IGUSP, com cinco espectrômetros com cristais TAP/STE, TAP/PET, LIF/PET, PET/LIF, automatizada com o sistema Voyager 3.61 da Noran Instruments.

Para as análises de granada, micas, anfibólios, estaurolita, clorita, cloritóide, piroxênio utilizou-se um feixe de elétron com diâmetro de $5 \mu \mathrm{m}$ e para o plagioclásio foi usado um feixe de $10 \mu \mathrm{m}$. Em todas as análises a corrente foi de $~ 20,1 \mathrm{nA}$ e voltagem de $15 \mathrm{KV}$.

As composições químicas dos minerais metamórficos foram definidas através de perfis composicionais, visando à determinação de zonamentos químicos e de suas relações de blastese com as foliações tectônicas externas e internas, visando o estabelecimento da cronologia relativa de cristalização (t). Sempre que possível foram analisadas as inclusões de minerais e o mineral hospedeiro em contato, objetivando uma melhor determinação das condições do metamorfismo para uma determinada zona composicional do mineral.

\subsection{Geotermobarometria}

As condições de pressão e temperatura dos litotipos selecionados foram obtidas utilizando-se o programa TWQ, versões 1.02 e 2.02b (Berman, 1991). Além disso foram usados os geotermômetros granada-clorita (Dickenson \& Hewitt, 1986), granadaestaurolita (Perchuck, 1991), clorita-cloritóide (Vidal et al., 1999).

Com base na petrografia detalhada das seções delgadas, foram efetuados os cálculos termobarométricos em amostras de cada um dos litotipos, focalizando principalmente as reações dos equilíbrios metamórficos. As análises de assembleias texturalmente em equilíbrio foram separadas das assembleias correspondentes a cada um dos domínios microestruturais e das cristalizadas em condições retrometamórficas. Concluída esta parte, foram avaliadas as melhores análises (melhor proporção catiônica e equilíbrios que representam) baseados na qualidade e precisão para aplicação nos cálculos geotermobarométricos, usando as análises representativas dos melhores equilíbrios de cada uma das assembleias.

As informações mineralógico-estruturais obtidas pela petrografia e os dados da química mineral, utilizadas em conjunto com a geotermobarometria possibilitaram não 
somente a estimativa das condições de temperatura e de pressão de formação das rochas, como também de suas trajetórias evolutivas no campo P-T, através do sequenciamento definido pelas relações de blastese com as foliações metamórficas (tempo relativo $-\mathrm{t}$ ).

Ressalta-se ainda que estes estudos não tiveram como fim o mapeamento das zonas metamórficas, razão pela qual os resultados obtidos são analisados segundo os estudos e mapas anteriores, destacando-se as alterações feitas na delimitação de algumas unidades geológicas, na classificação, tipo e grau metamórfico de algumas rochas.

\section{LOCALIZAÇÃO DA ÁREA DE ESTUDO}

Os Xistos de Ancón, os Gnaisses de La Miel, o Anfibólio Xisto de Caldas são unidades que afloram ao sul e sudeste da cidade de Medellín, perto do município de Caldas, e pequenos afloramentos perto do município de Sabaneta. Entretanto, para Restrepo \& Toussaint (1984) as rochas que afloram ao noroeste de Medellín poderiam corresponder a uma extensão dos Xistos de Ancón que ocorrem ao sul, que poderiam estar cobertos por depósitos quaternários do Valle de Aburrá. Os Anfibolitos, Migmatitos e Granulitos de El Retiro afloram ao leste de Medellín, perto do município de El Retiro e La Ceja. Alguns afloramentos deste corpo, distribuem-se nos arredores da cidade de Envigado.

As áreas selecionadas para os estudos localizam-se no flanco ocidental da Cordilheira Central dos Andes colombianos, no Estado de Antioquia, nos arredores da cidade de Medellín (Figura 1). O acesso para a zona de Caldas é feito pela rodovia sul Medellín - Caldas e os afloramentos encontram-se localizados principalmente em ribeirões e raramente em estradas de terra de algumas fazendas da área. $\mathrm{Na}$ área situada mais a noroeste o acesso é feito através da rodovia Medellín - San Jerónimo e, da mesma forma, os afloramentos apresentam-se em ribeirões e alguns deles nos cortes da própria estrada. Na porção sul o acesso é feito através da rodovia Sul até os municípios de Envigado e Sabaneta e os principais afloramentos também ocorrem nos ribeirões da região. A parte leste é alcançada pela estrada Loma del Escobero e daí até os municípios de El Retiro e La Ceja pela estrada Las Palmas. Nesta área a maioria dos afloramentos situa-se na própria estrada, com alguns deles em ribeirões. 


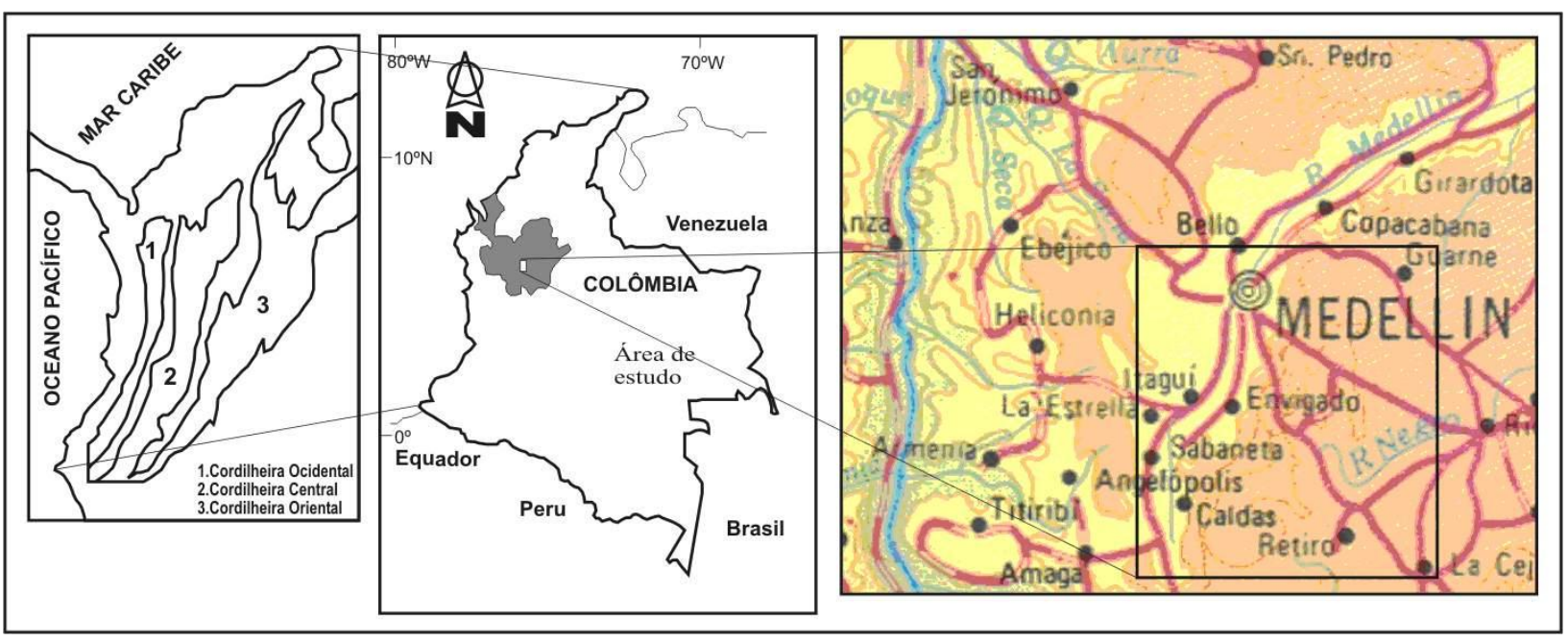

Figura 1. Localização da área estudada, na qual em vermelho estão representadas as principais estradas partindo da cidade de Medellín.

\section{CONTEXTO GEOLÓGICO REGIONAL}

Os Andes são divididos em três segmentos, denominados Andes do Norte, Andes Centrais e Andes do Sul (Figura 2), cada um deles com características geológicas distintas (Ramos, 1999; Ramos \& Aleman, 2000). O segmento norte ocidental localiza-se ao norte do golfo de Guayaquil (Colômbia e Equador) e é caracterizado pela presença de terrenos mesozóicos oceânicos acrescidos à crosta continental entre o Mesozóico Superior e o Mioceno (Kerr et al., 2002).

Os Andes na Colômbia dividem-se em três cadeias de montanhas, denominadas cordilheiras Oriental, Central e Ocidental (Figura 3). Geologicamente pode ser dividido em dois grandes domínios, formados por diferentes terrenos tectono-estratigráficos (Restrepo \& Toussaint, 1988). O Domínio Ocidental, que inclui a Cordilheira Ocidental e a margem ocidental da Cordilheira Central, tem caráter ensimático, sendo constituído por rochas vulcano-sedimentares de afinidade oceânica e complexos ofiolíticos acrescidos à margem continental durante o Mesozóico-Cenozóico. A porção siálica é representada por dois terrenos principais, quais sejam:

a) Oriental, que corresponde ao embasamento metamórfico de alto grau précambriano coberto por complexos metassedimentares e rochas sedimentares do Paleozóico Inferior e Superior. O conjunto foi invadido por intrusões de granitóides, acompanhados por sedimentação no Mesozóico, resultando na formação de um arco magmático continental, cuja evolução das fases de rift e de margem passiva são 


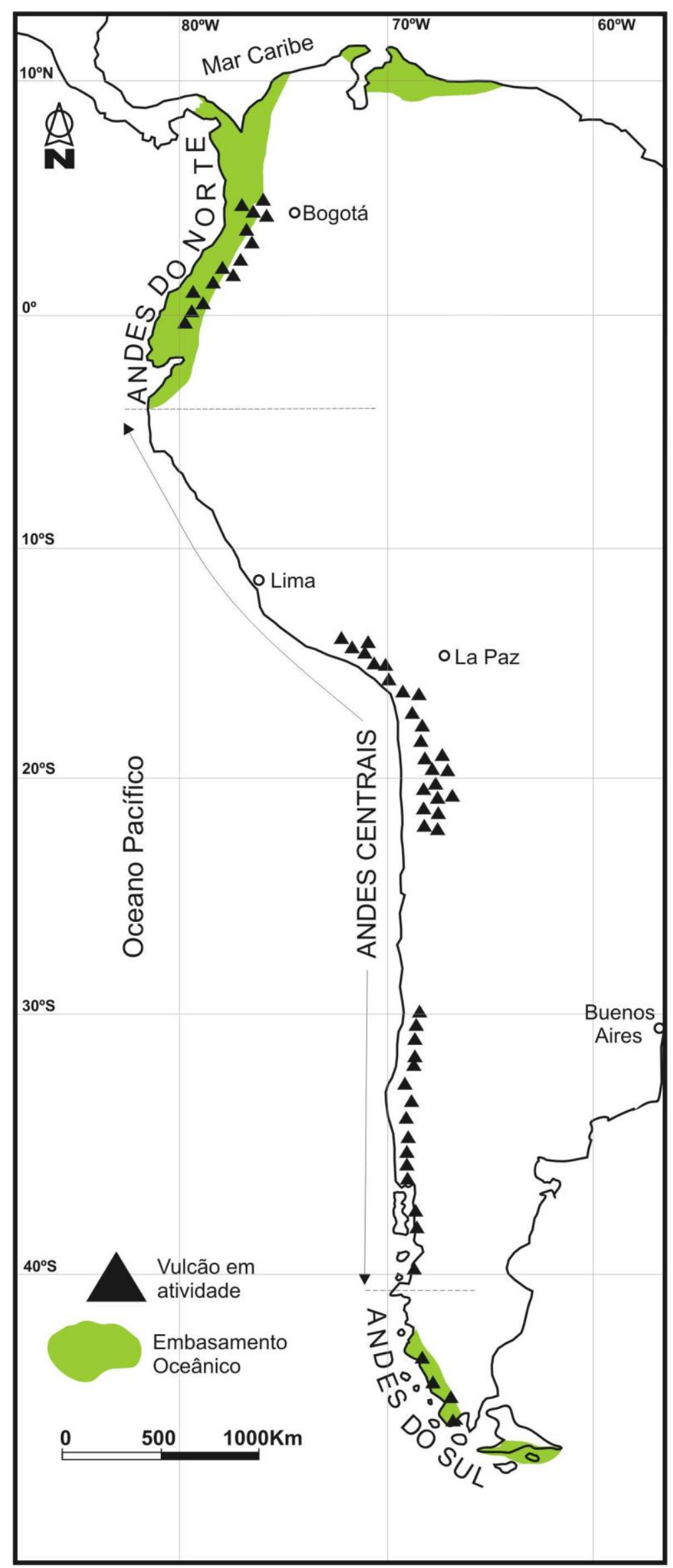

Figura 2. Divisão tectônica da Cordilheira dos Andes. Modificada de Ramos \& Aleman (2000). 


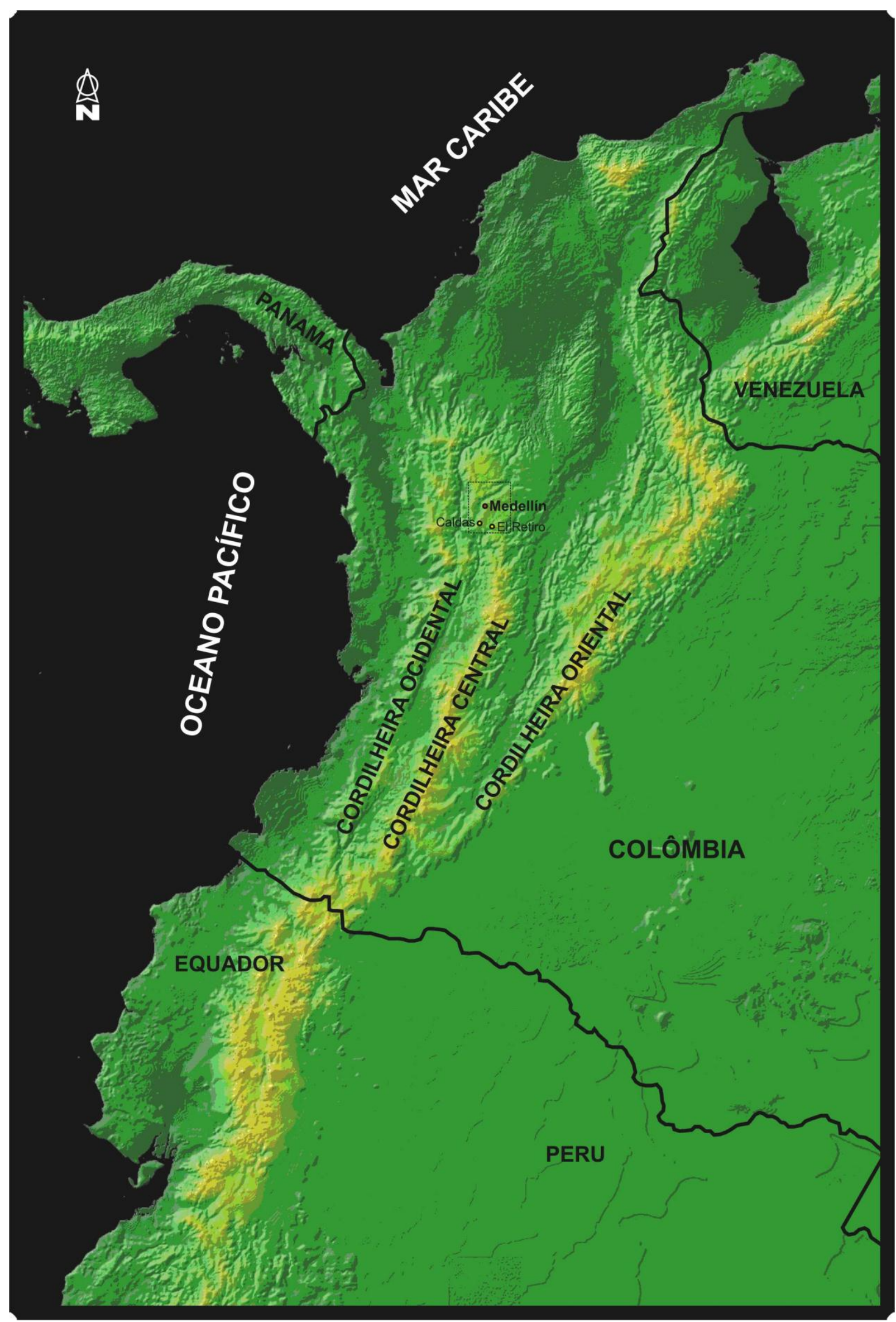

Figura 3. Divisão dos Andes colombianos em suas três principais cordilheiras. 
características da margem ocidental das Américas (Dickinson \& Lawton, 2001). À sedimentação de margem passiva seguiu-se uma inversão tectônica, a instalação de um sistema de foreland relacionado com a orogenia andina e a acresção dos domínios oceânicos ocidentais. Este domínio tem sido considerado um terreno tectonoestratigráfico acrescido no Paleozóico (Restrepo \& Toussaint, 1988, Forero-Suárez, 1991).

b) Um terreno de afinidade continental, localizado no núcleo da Cordilheira Central, constituído predominantemente por uma série complexos polimetamórficos com magmatismo associado, de idades variando entre o Paleozóico Médio e o Triássico. A acresção deste terreno à margem continental é considerada como relacionada a acresção dos outros domínios oceânicos durante o Cretáceo Superior (Toussaint, 1996). Este terreno constitui um elemento fundamental na compreensão da evolução geológica dos Andes Norte-Ocidentais, uma vez que seu embasamento metamórfico registra a complexa história geológica ocorrida entre o Paleozóico Inferior até o Triássico, relacionada à evolução Hercínica da margem ocidental do Gondwana, e da acresção e dispersão da Pangea (Jaillard et al., 1991; Megard et al., 1987; Noble et al., 1997; Vinasco, 2001), cuja natureza encontra-se ainda pouco compreendida. A zona de estudo insere-se no contexto geológico deste domínio. Segundo Maya (2001), o flanco ocidental e o núcleo da Cordilheira Central são limitados pela Falha OtúPericos a leste e a Falha Cauca-Almaguer (Romeral) a oeste. Fazem parte desta porção tectono-estratigráfica várias unidades metamórficas do Complexo Polimetamórfico da Cordilheira Central e algumas unidades sedimentares e vulcânicas (Figura 4).

Durante vários anos têm sido realizados muitos estudos geológicos de caráter regional nesta porção dos Andes do Norte, mas poucos têm enfocado a evolução metamórfica e sua relação com a evolução tectônica. Em muitos deles são introduzidos novos nomes e divisões de unidades litoestratigráficas que dificultam o entendimento das condições do metamorfismo que afetou a região.

Outros estudos baseiam-se na geocronologia, resultado de datação de amostras de várias das unidades geológicas, em sua maioria não embasados em uma base cartográfica atualizada, feitos em áreas sem detalhamento dos processos geológicos e sem uma amostragem sistemática que permita correlacionar a evolução geológica e as idades. Entretanto, nos últimos anos, diversos pesquisadores têm enfocado o problema do metamorfismo e sua importância no estudo da evolução tectônica, desenvolvendo 


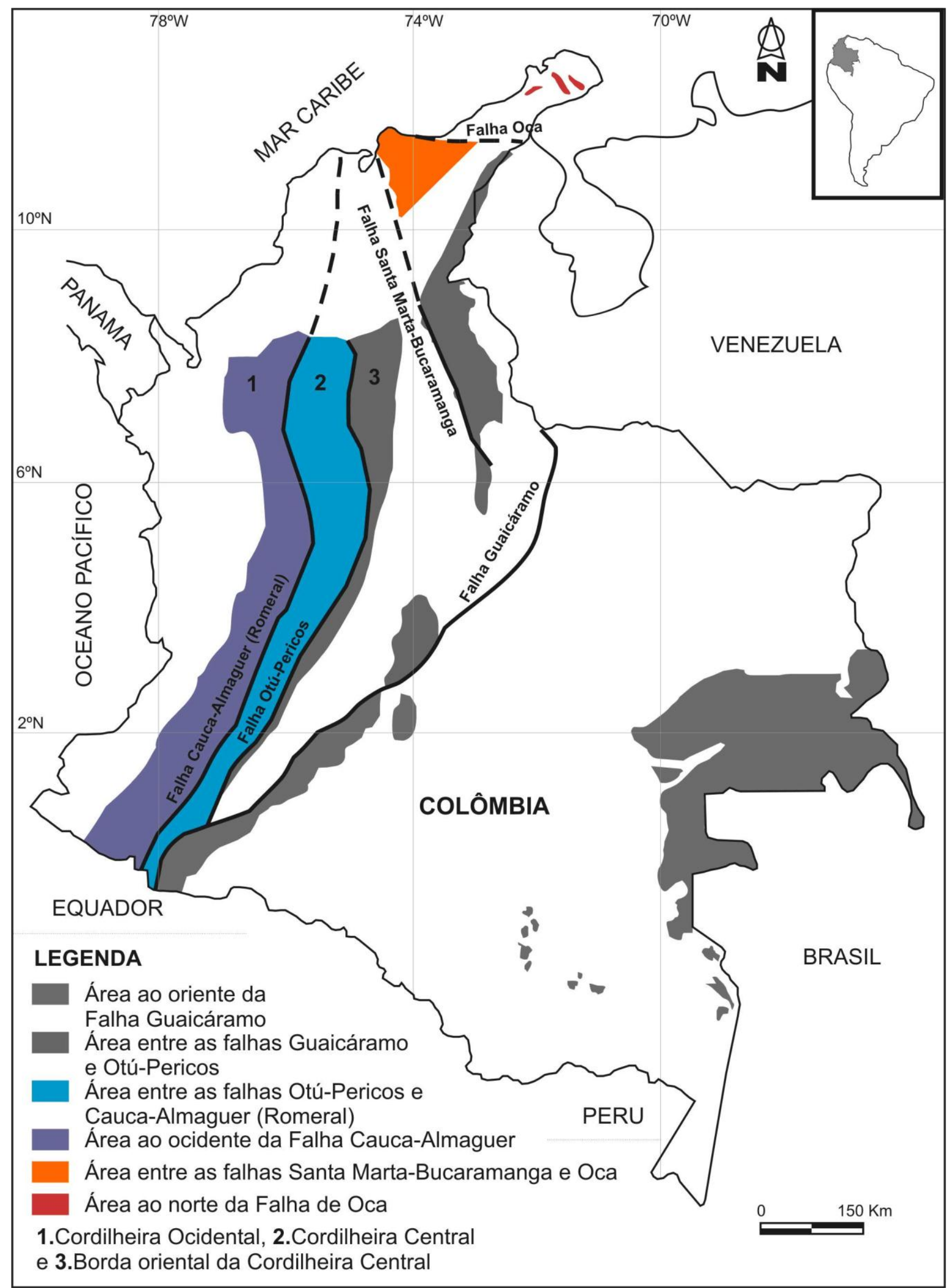

Figura 4. Distribuição geográfica das áreas com rochas metamórficas na Colômbia (Maya, 2001). 
mapeamentos detalhados das unidades geológicas, acompanhados da aplicação de várias ferramentas, entre elas a geocronologia, resultando em importantes contribuições ao melhor entendimento da evolução geológica da região. Neste aspecto podem ser destacados os trabalhos de Ordóñez (1997; 2001) e Vinasco (2001), que tem apresentado grande número de dados que resultaram em revisões e novas interpretações dos modelos evolutivos. $\mathrm{Na}$ área da petrologia metamórfica, poucos dados novos têm sido apresentados desde final da década de 1990, sendo que os mais recentes são, em geral, reinterpretações de trabalhos anteriores ou reedição de mapas geológicos. Com o surgimento do conceito dos metamorfismos superpostos na Cordilheira Central (Restrepo \& Toussaint, 1982) os pesquisadores têm revisado os modelos de evolução desta parte dos Andes e os trabalhos têm sido focalizados na diferenciação dos diferentes eventos tectono-metamórficos que afetaram a região.

Os estudos mineralógicos mais detalhados e a aplicação dos conceitos das séries de fácies de Miyashiro (1961), assim como a descoberta das características do metamorfismo do Grupo Arquía e das rochas metamórficas de média e alta pressão do flanco ocidental da Cordilheira Central, contrastantes com as rochas de baixa pressão no eixo da cordilheira, além do aumento nos dados geocronológicos, têm permitido estabelecer que as rochas metamórficas da Cordilheira Central teriam sofrido vários eventos tectono-metamórficos superpostos no tempo e espaço (Restrepo \& Toussaint, 1982; Toussaint, 1993). Por isto, as rochas metamórficas da Cordilheira Central não podem ser agrupadas num único conjunto e o uso do termo Complexo Polimetamórfico da Cordilheira Central (Restrepo \& Toussaint, 1984) é o mais adequado para referir-se a todo conjunto de rochas metamórficas que compõe a cordilheira.

Segundo McCourt (1984), as rochas metamórficas da Cordilheira Central podem ser agrupadas em dois diferentes grupos: Grupo de Xistos do Leste, encontrado nas partes mais altas, que constitui o flanco oriental da cordilheira, formado pelas rochas metamórficas de baixa pressão; o Grupo de Xistos do Oeste, que compõe o flanco ocidental da Cordilheira Central e corresponde a rochas de média e alta pressão.

Segundo Maya \& González (1995), a Cordilheira Central é constituída por quatro unidades litodêmicas (Figura 5) separadas por falhas, cuja exposição ocorre de maneira contínua, desde os limites com Equador até os $6^{\circ}$ de latitude norte. A unidade mais ao ocidente é composta por rochas vulcânicas mesozóicas e alguns dos conjuntos definidos por Maya \& González (1995), fazem parte da Cordilheira Ocidental, razão pela qual não serão aqui descritos. Desta forma, as unidades de interesse nesta 


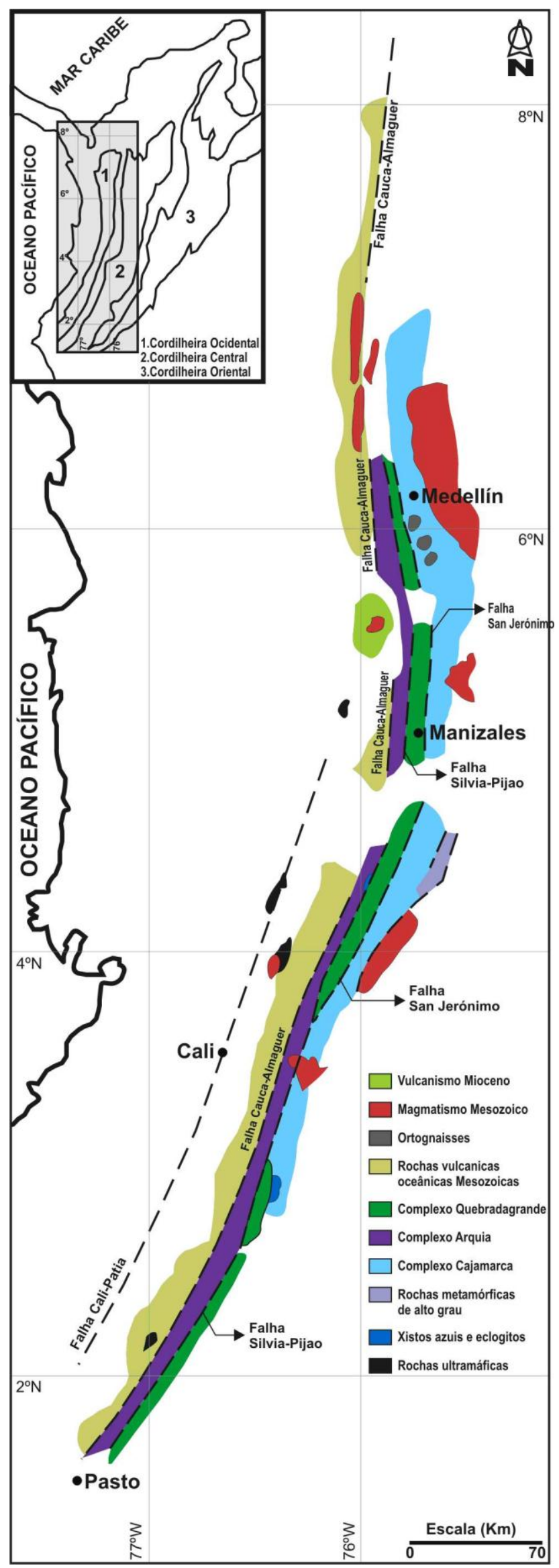

Figura 5. Divisão da Cordilheira Central dos Andes colombianos em unidades litodêmicas (Maya \& González, 1995). 
pesquisa são:

Complexo Cajamarca segundo Nelson (1957) é composto por quartzo-sericita xistos, xistos verdes, filitos e algumas camadas de mármores que afloram na seção Cajamarca - Alto de La Línea, entre as falhas Otú-Pericos e Chapetón-Pericos, e a falha Aranzazu - Manizales (Mosquera et al., 1982). Entre as cidades de Mariquita e Manizales $\left(3^{\circ} 35^{\prime} \mathrm{N}\right)$, as rochas do Cajamarca afloram desde a falha de Mulato até a falha de San Jerónimo, perto da cidade de Manizales, e encontram-se parcialmente cobertas por material vulcânico (Mosquera, 1978). Neste perfil as rochas do Complexo Cajamarca estão associadas com rochas de alto grau metamórfico (Maya \& González, 1995). Depois dos 5³0' de latitude norte, os quartzo-sericita xistos, actinolita xistos e quartzitos afloram somente na parte central da Cordilheira Central. A leste da Falha Otú, o Complexo é composto por metapelitos, rochas metamórficas de baixo grau, gnaisses, gnaisses alumínicos, hornblenda gnaisses, quartzitos, escarnitos, mármores e anfibolitos (Feininger, 1972). A oeste da Falha Otú ocorrem os Granulitos de El Retiro, os Anfibólio Xistos de Caldas, o Gnaisse de La Miel e outros corpos de anfibolitos e migmatitos que também são inseridos dentro do Complexo Polimetamórfico da Cordilheira Central (Restrepo \& Toussaint, 1984), objetos principais desta pesquisa.

Complexo Quebradagrande: segundo Maya \& González (1995), este Complexo deve ser dividido em duas unidades litodêmicas, uma sedimentar e outra vulcânica. Ambas afloram entre os complexos Cajamarca e Arquía e são limitadas pelas falhas San Jerónimo a leste e Silvia-Pijao a oeste.

Complexo Arquía: localiza-se a oeste do Complexo Quebradagrande, é limitado pela Falha Silvia-Pijao a leste e pela Falha Cauca-Almaguer a oeste e é composto por rochas metassedimentares e metaígneas (Maya \& González, 1995). Este conjunto agrupa várias unidades de rochas metamórficas que incluem quartzo-sericita xistos, actinolita xistos, quartzitos e rochas metamórficas de baixo grau (Orrego et al., 1993). Rochas metamórficas com protólitos de afinidade oceânica, anfibolitos, xistos verdes, anfibólio xistos, granada anfibolitos também fazem parte deste Complexo, descrito em detalhe por Restrepo \& Toussaint (1975), Toussaint \& Restrepo (1978), Mosquera (1978), Restrepo et al. (1978), González (1980), Grotjohann \& McCourt (1981), Esquivel et al. (1981), Murcia \& Cepeda (1991a; b) e Orrego \& Paris (1991). Também fazem parte do Complexo Arquía os xistos azuis e eclogitos (Orrego et al., 1980; McCourt \& Feininger, 1984). 


\section{GEOLOGIA LOCAL}

As unidades estudadas fazem parte do Complexo Polimetamórfico da Cordilheira Central (Restrepo \& Toussaint, 1984) que compõe parte do embasamento da Cordilheira Central dos Andes colombianos, denominado de Complexo Cajamarca (Nelson, 1957). São elas os Xistos de Ancón, o Anfibolito de Caldas, o Gnaisse de La Miel e os Granulitos e Migmatitos de El Retiro. O Anfibolito de Caldas é composto predominantemente por rochas foliadas, razão pela qual é adotada neste trabalho a denominação de Anfibólio Xistos de Caldas. Na área de ocorrência da unidade dos Granulitos e Migmatitos de El Retiro são relativamente poucos os afloramentos de granulitos e predominam anfibolitos e migmatitos, razão pela qual a unidade deverá ser redefinida e renomeada, o que não foi feito neste trabalho, por não ser este o objetivo das pesquisas efetuadas, mas neste trabalho é adotado a denominação Anfibolitos, Migmatitos e Granulitos de El Retiro, indicando que os anfibolitos são o litotipo mais abundante e os granulitos o litotipo mas escasso.

Dois eventos tectono-metamórficos paleozóicos foram identificados até 0 presente momento na região, um deles devoniano, definido por datações $\mathrm{Rb}-\mathrm{Sr}$ em ortognaisses, e outro permiano-triássico, caracterizado por datações $\mathrm{Rb}-\mathrm{Sr}$ e $\mathrm{K}-\mathrm{Ar}$ (Restrepo \& Toussaint, 1982). O mais alto grau metamórfico deste evento, datado através de isócrona $\mathrm{Sm}-\mathrm{Nd}$ granada-rocha total de granulito, ocorreu no triássico (Ordóñez et al., 2000).

As rochas de alto grau metamórfico ocorrem em áreas restritas do complexo e alguns autores consideram que parte dos terrenos de alto grau metamórfico podem ser pré-cambrianos, apesar de não existirem ainda datações radiométricas que confirmem esta hipótese (Ordóñez et al., 2000).

As unidades onde serão concentrados os estudos (Figura 6) deste projeto são as seguintes:

\subsection{Anfibólio Xistos de Caldas}

Botero (1963) definiu estas rochas do corpo Anfibolítico de Caldas como ortoderivadas e pertencentes Grupo Ayurá-Montebello, mas estudos subsequentes demonstraram que este Grupo incluía unidades litotípicas de origens diversas (Echeverría, 1973). A ocorrência de extensos afloramentos de anfibolitos granatíferos foi pela primeira vez reportada por Restrepo \& Toussaint (1978), que também os 


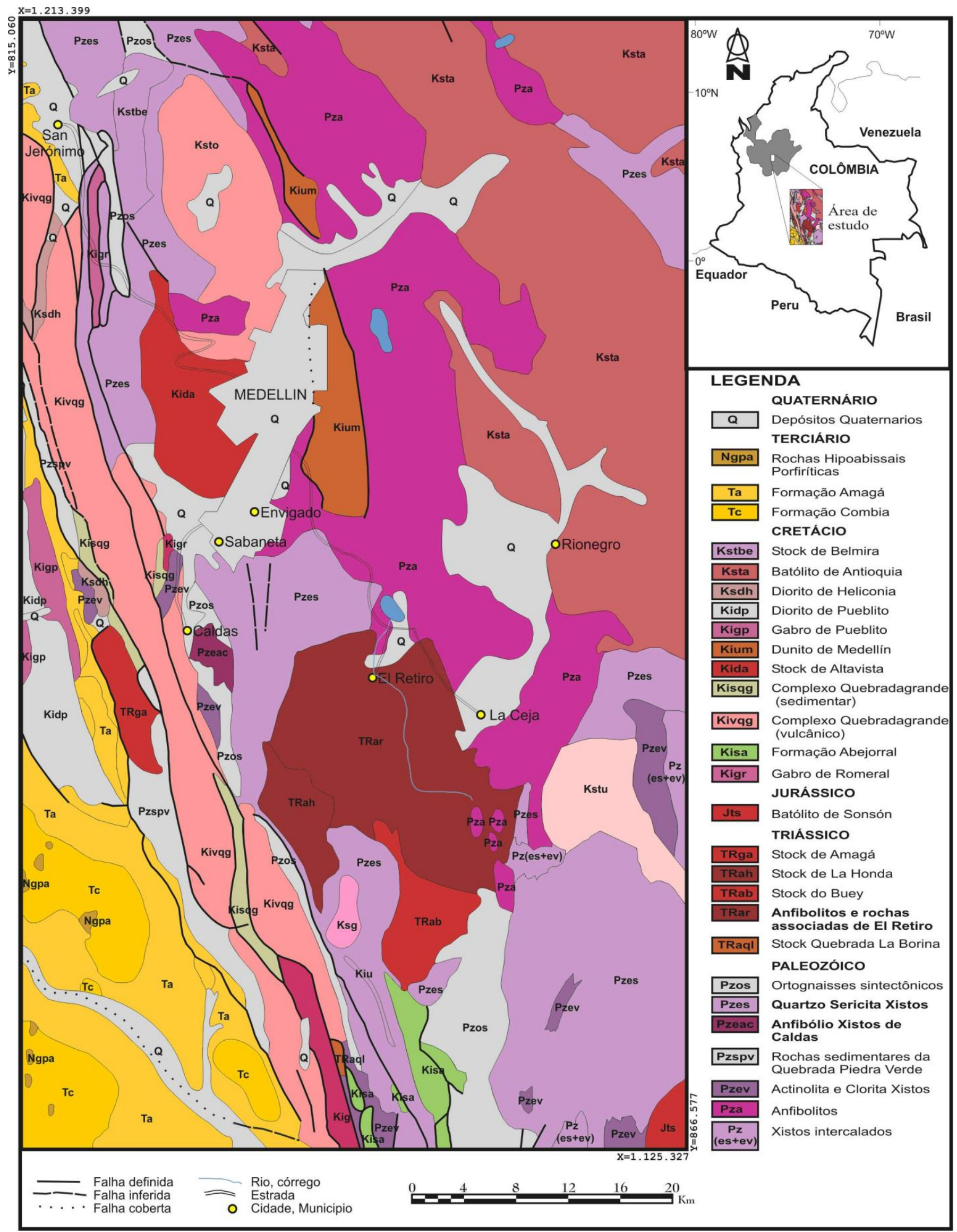

Figura 6. Mapa dos litotipos da área de estudo e arredores. Modificado do mapa geológico de Antioquia, Ingeominas (1996). 
consideraram como formados em regime metamórfico de pressão intermediária.

As rochas do Anfibólio Xistos de Caldas tem composição relativamente homogênea e afloram na margem direita do Rio Medellín a leste, a sudeste da cidade de Caldas (Noreña \& Patiño, 1984). Inserem-se nos anfibólio xistos delgadas intercalações de biotita xistos com estaurolita (Restrepo, 1986), indicando que o grau médio foi alcançado nesta unidade. Os anfibolitos são formados principalmente por hornblenda, oligoclásio e granada almadínica, com quartzo, epidoto, ilmenita, magnetita, clorita e, mais raramente, biotita subordinados (Restrepo, 1986). Texturalmente são identificados dois eventos deformacionais, sendo o primeiro deles definido pela orientação planar dos cristais de hornblenda $\left(S_{1}\right)$, e o segundo por dobras suaves da $S_{1}$, acompanhado por leve rotação da granada (Restrepo, 1986).

O granada anfibolito foi datado pelo método $\mathrm{K}-\mathrm{Ar}$ em hornblenda, resultando em idades de $324 \pm 16$ Ma e $319 \pm 48$ Ma e $306 \pm 15 \mathrm{Ma}$ em rocha total (Restrepo et al., 1991).

$\mathrm{Na}$ região estudada este conjunto aflora a leste, sudeste e sul da cidade de Caldas, principalmente na margem direita do Rio Medellín. As rochas são compostas predominantemente por anfibólio orientado e porfiroblastos de granada, com quartzo e plagioclásio subordinados e, às vezes biotita. Inserem-se nos anfibólio xistos delgadas intercalações de biotita xistos com estaurolita. Apenas em um afloramento observou-se o contato do anfibólio xisto com os metapelitos, o qual é abrupto, indicando terem sido formados os protólitos em hiatos do vulcanismo pela deposição de sedimentos clásticos finos. Neste contexto, a abundância de vênulas e veios de quartzo metamorfisados podem representar zonas de silicificação e/ou de exalitos silicosos na seqüência vulcano-sedimentar.

Os anfibólio xistos apresentam cor verde-escura (Foto 1), com zonas de concentração de porfiroblastos de granada. $O$ anfibólio possui sempre granulação muito fina, raramente constituindo cristais mais grossos, com até $3 \mathrm{~mm}$ de comprimento, estes sempre desorientados, indicando cristalização pós-cinemática. É comum encontrar-se concentrações de granada em camadas e porções da rocha onde este mineral desaparece quase que totalmente.

Também ocorrem áreas com uma grande quantidade de leitos silicosos descontínuos, por vezes laminados, e veios de quartzo dobrados e estirados (Foto 2), as quais se associam, possivelmente a zonas de silicificação pré-metamórfica e, 

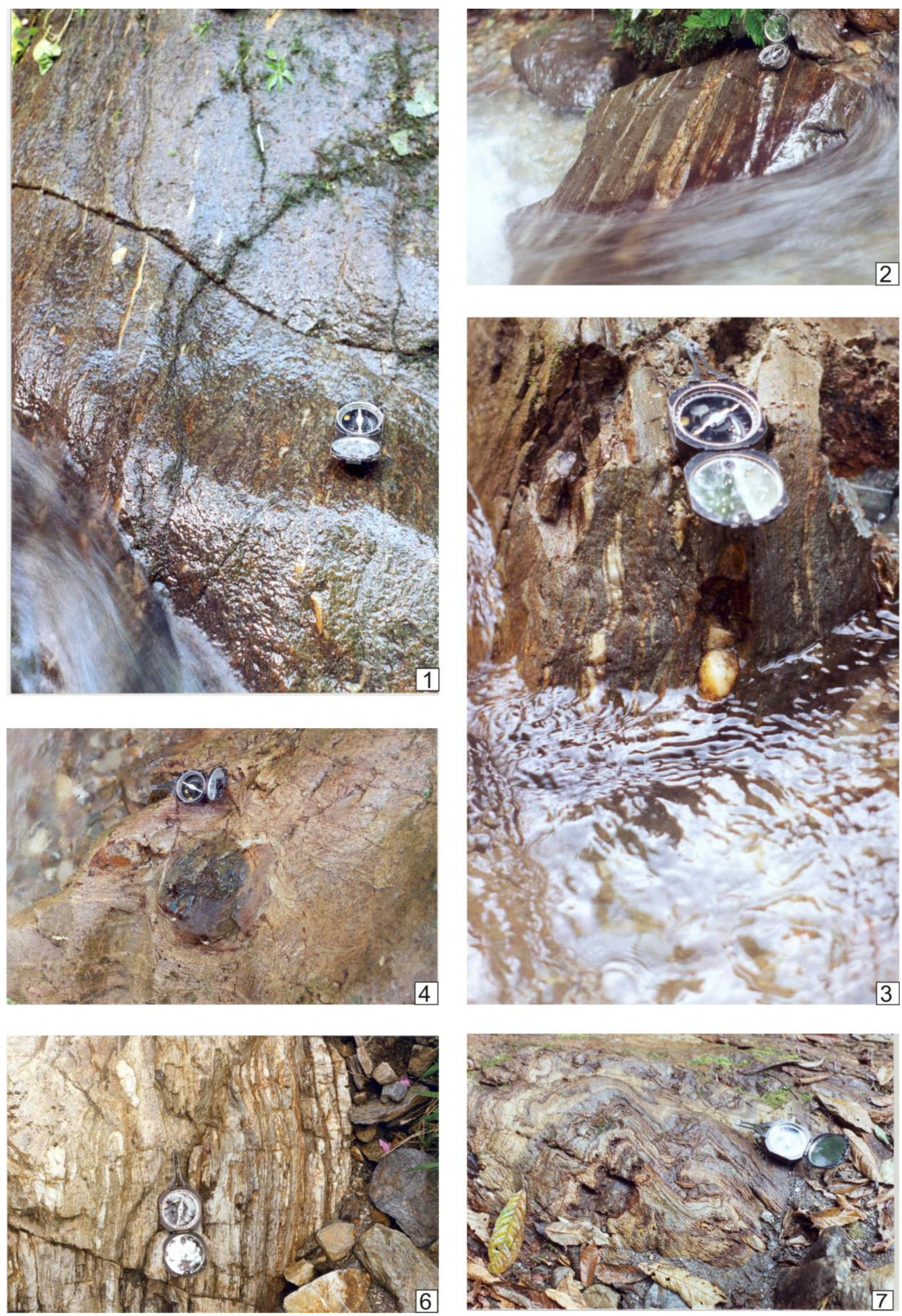

1 Afloramento dos Anfibólio Xistos de Caldas. 2 Veios de quartzo nos Anfibólio Xistos de Caldas. 3 Veios de quartzo dobrados e veio com aspecto de seixo estirado nos Anfibólio Xistos de Caldas. 4 Xenólito do Anfibólio Xisto de Caldas no Gnaisse de La Miel. 6 Afloramento dos Xistos de Ancón. 7 Intenso dobramento nos Xistos de Ancón. 
seguramente ao intenso hidrotermalismo e deformação gerada pelo desenvolvimento do metamorfismo regional e de zonas de cisalhamento. $O$ hidrotermalismo resultou em silicificação em intensidade variável dentro do corpo, mas está principalmente concentrada em zonas fraturadas. Evidências claras de deformação também são observadas nos afloramentos, mostrando principalmente veios de quartzo dobrados, intensamente deformados, e outros com aspecto de seixos estirados (Foto 3 ), menos deformados, indicando que a silicificação ocorreu concomitantemente ao desenvolvimento da deformação, mais especialmente aquela associada a zonas de cisalhamento.

O conjunto é cortado por um corpo de granito metamorfisado, cuja geometria não pode ser definida em campo, denominado de Gnaisse de La Miel, onde é possível a observação de xenólitos do anfibólio xisto (Foto 4).

\subsection{Xistos de Ancón}

Quartzo-muscovita xistos com quantidades variáveis de grafita são os litotipos mais abundantes na Cordilheira Central (Restrepo, 1986). Os Xistos de Ancón estendem-se de um modo aparentemente contínuo do sul de Ancón até o leste do Alto de Minas e a cidade de Caldas (Restrepo \& Toussaint, 1984). Inicialmente estas rochas foram consideradas como parte do Grupo Ayurá-Montebello (Botero, 1963) e estariam intercaladas concordantemente nos Anfibolitos de Caldas (Saldarriaga \& Sepúlveda, 1980).

Em geral são rochas mineralogicamente monótonas, com a presença de muscovita, quartzo e biotita em proporções diversas, mas variações composicionais locais são também descritas, com clorita, biotita, cloritóide, andalusita, albita-oligoclásio, granada, estaurolita e, mais raramente, cianita (Saldarriaga \& Sepúlveda, 1980; Restrepo, 1986). Texturalmente apresentam pelo menos duas foliações metamórficas, às quais se associam diferentes minerais recristalizados (Escobar \& Maya, 1985).

O grau metamórfico em geral situa-se na fácies xisto verde, como indicado pela associação com clorita e cloritóide, mas o grau médio foi alcançado, levando à formação de estaurolita (Restrepo, 1986), notadamente nas proximidades da cidade de Caldas (Restrepo \& Toussaint, 1984). O regime bárico varia de pressão baixa (Abukuma) a intermediária (Barrowiano), com andalusita e cianita, mas as relações da variação da pressão com as deformações ou com metamorfismo de contato junto aos 
ortognaisses não estão ainda bem caracterizadas.

Radiometricamente a unidade foi datada pelo método $\mathrm{K}-\mathrm{Ar}$ em rocha total, resultando em idade de $270 \pm 10$ Ma (Restrepo et al., 1978), e de $226 \pm 4$ Ma por $\mathrm{Rb}-\mathrm{Sr}$ (Restrepo et al., 1991).

Esta unidade é um corpo formado predominantemente por quartzo-muscovita xistos com quantidades variáveis de granada e minerais máficos subordinados que se estende, aparentemente continuamente, de Ancón Sul até o leste do Alto de Minas e a cidade de Caldas. Segundo Restrepo \& Toussaint (1984) a continuação desta unidade na parte norte de Medellín (Boquerón) poderia estar representada pelos xistos com biotita e andalusita (às vezes chiastolita), mas no presente estudo foram estudadas algumas amostras desta área e a mineralogia não é diagnóstica para aceitar ou rejeitar sua relação. Na sua porção sul foram amostrados dois afloramentos com andalusita que possuem também fibrolita e quantidades variáveis de turmalina, possivelmente de origem hidrotermal. Nesta área também ocorrem intercalações pouco expressivas de grafita xistos intensamente alterados. As rochas em geral não se encontram muito deformadas e somente em alguns afloramentos é possível observar uma crenulação que afeta a xistosidade.

Os contatos com os Anfibólio Xistos de Caldas não são claros, mas a ausência de estruturas entre as duas unidades, assim como áreas com grau metamórfico semelhante, intensidade e estilo das deformações e a presença de gradientes metamórficos entre ambas as unidades, sugerem uma forte relação tectonometamórfica.

As características das rochas variam nas diferentes regiões, como descrito a seguir:

Região de Caldas: as amostras desta área apresentam variações mineralógicas apreciáveis. No Córrego La Miel (amostras 2, 3, 15f, 15e, 16, 16e, 16f, 68 e 70) as rochas são foliadas (Foto 5) e compostas, em essência, por quartzo, muscovita e pequenos cristais de granada disseminados. Sulfetos em quantidades variáveis são também observados, mas na maioria das amostras estes minerais encontram-se fortemente oxidados, impossibilitando sua identificação. Um pouco mais ao norte, ainda no município de Caldas, no córrego La Romera (amostras 46, 46b e 46c) e em um afluente deste córrego (amostras 45b, 45e e 45f) ocorrem quartzo-biotita xistos com quantidades variáveis de granada e, às vezes estaurolita, e grafita xistos com sulfetos, principalmente pirita, e micas (muscovita e sericita). Estas rochas raramente afloram e 
várias das amostras foram coletadas de blocos rolados no leito dos córregos. Somente no córrego La Romera foi encontrado um afloramento de quartzo-biotita xisto com granada e estaurolita, o qual está em contato abrupto com biotita-granada xistos intensamente cisalhados (Foto 6) e dobrados (Foto 7). No córrego La Tablacita (amostras 56, 56b, 56c e 57) as rochas encontram-se fortemente alteradas, sendo possível a identificação apenas de alguns dos minerais que as compõem. As rochas nesta área são principalmente quartzo-muscovita xistos com quantidades variáveis de feldspato e, mais raramente, com granada subordinada. As rochas apresentam uma clara crenulação que dobra e transpõe a foliação principal.

No município de Sabaneta, na entrada da fazenda La Montañita (amostras 58 e 58b) afloram feldspato-quartzo xistos com muscovita e intercalações de quartzitos. Neste afloramento também ocorre um dique de diabásio amigdaloidal, cujo principal preenchimento é, possivelmente, de zeólitas. Um pouco mais ao norte, também no município de Sabaneta, no córrego La Doctora (amostras 59, 60 e 60b), ocorrem quartzo-muscovita xistos com quantidades variáveis de biotita e pirita. Em uma das amostras foi observado um porfiroblasto de chiastolita, indicando que a rocha foi afetada por metamorfismo de baixo grau. Neste córrego aflora também uma lente de rocha quartzo-feldspática com pouca quantidade de micas, orientadas segundo uma foliação pouco definida. Finalmente, ao norte de Medellín, encontra-se a área do Boquerón (amostras 48, 49, 50 e 50b), na qual ocorrem andalusita-biotita xistos cortados por diques básicos que geram nos xistos chilled margins (Foto 8 ).

\subsection{Gnaisse de La Miel}

Este corpo foi descrito inicialmente por Echeverría (1973) a leste da cidade de Caldas e nos primeiros mapas geológicos da região estas rochas foram incluídas na unidade metassedimentar do grupo Ayurá-Montebello (Botero, 1963). Entretanto, Saldarriaga \& Sepúlveda (1980), Noreña \& Patiño (1984) e Restrepo (1986) demonstraram indubitavelmente que o protólito do gnaisse é ígneo e intrusivo no Anfibolito de Caldas (Restrepo \& Toussaint, 1984) e o separaram do Grupo AyuráMontebello. O gnaisse é composto, em essência, por ortoclásio geralmente invertido para oligoclásio, quartzo, muscovita, biotita, clorita e, ocasionalmente, granada (Saldarriaga \& Sepúlveda, 1980). As paragêneses indicam que o metamorfismo foi de baixo a médio grau, com retrometamorfismo na fácies xisto verde, mas não é possível, pela ausência de minerais diagnósticos, a determinação do tipo bárico do 
metamorfismo (Saldarriaga \& Sepúlveda, 1980).
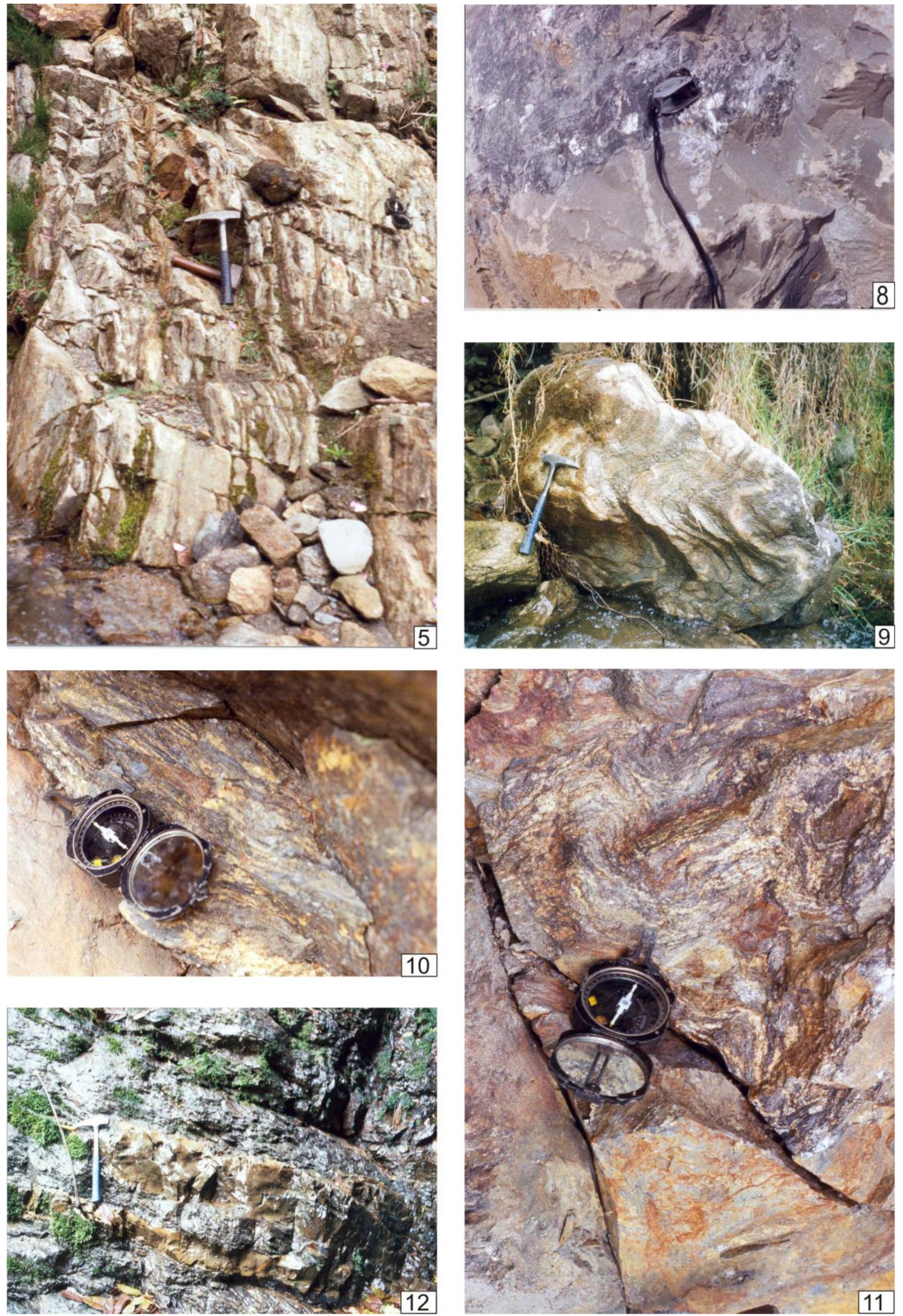

5 Afloramento dos Xistos de Ancón. 8 Dique básico em contato com os xistos da área de Boquerón. 9 Bloco rolado do Gnaisse de La Miel no qual o bandamento esta intensamente dobrado. 10 Estrutura estromática nos migmatitos da unidade de Anfibolitos, Migmatitos e Granulitos de El Retiro. 11 Estrutura dobrada nos migmatitos da unidade de Anfibolitos, Migmatitos e Granulitos de El Retiro. 12 Diques básicos cortando os migmatitos da unidade de Anfibolitos, Migmatitos e Granulitos de El Retiro. 
O gnaisse foi datado pelo método $\mathrm{K}-\mathrm{Ar}$ em muscovita, resultando em $343 \pm 12$ Ma (Restrepo \& Toussaint, 1978), e por Rb-Sr em $391 \pm 2$ Ma (Restrepo et al., 1991).

Nos levantamentos efetuados o corpo de gnaisse aflora principalmente no município de Caldas, no córrego La Miel.

As rochas possuem granulação heterogênea, mas a mineralogia é relativamente homogênea, sendo compostas por feldspatos, quartzo e quantidades variáveis de muscovita e biotita. Zonas enriquecidas em clorita, devido a retrometamorfismo e hidrotermalismo são também comuns. A deformação que afeta os litotipos é bem evidenciada pelo estiramento e fraturamento dos cristais de feldspato, caracterizando que o tectonismo iniciou-se em temperaturas relativamente altas, compatíveis com a fácies anfibolito, e evoluiu para regimes rúpteis com a queda da temperatura. Apesar da deformação a estrutura gnáissica raramente é observável mas, quando presente, é possível observá-la dobrada (Foto 9). Estruturas augen são observadas em alguns afloramentos, indicando a existência de fácies porfiríticas no corpo.

\subsection{Anfibolitos, Migmatitos e Granulitos de EI Retiro}

Tal qual as unidades anteriores, estes litotipos foram inicialmente incluídos por Botero (1963) no Grupo Ayurá-Montebello, mas estudos feitos por González (1980) ao sul de El Retiro mostraram que a região é constituída predominantemente por migmatitos e granulitos, tendo sido então individualizada esta unidade de mais alto grau metamórfico. Entretanto, neste trabalho observou-se que os afloramentos de granulitos e de gnaisses são relativamente escassos, predominando corpos de anfibolito e migmatito na região estudada.

O migmatito é principalmente do tipo estromático, localmente ocorrendo os tipos schlieren e nebulítico e, em algumas áreas, afloram pegmatitos encaixados discordantemente nas rochas (Restrepo, 1986). Os mesossomas e melanossomas são ricos em biotita e podem apresentar agregados de fibrolita e, mais raramente, de granada de cor rosa e estaurolita (Restrepo, 1986). O leucossoma é composto basicamente por quartzo e feldspato potássico e, às vezes, associam-se pequenos cristais de micas brancas (Ardila, 1986). Os granulitos tem composição variando de enderbito a hiperstênio monzodiorito e hiperstênio monzonorito (Ardila, 1986), por vezes com granada (Ordóñez et al., 2000), e tem associados gnaisses e anfibolitos.

A idade deste conjunto, obtida pelo método $\mathrm{K}-\mathrm{Ar}$ em rocha total é de $251 \pm 21$ Ma (Restrepo, 1986) e uma isócrona Sm-Nd em granada-rocha total forneceu idade 
de $226 \pm 10$ Ma (Ordóñez, 2001).

Este conjunto de rochas aflora a leste da cidade de Medellín, nas proximidades dos municípios de El Retiro e La Ceja. Alguns afloramentos dos migmatitos encontramse na estrada Loma del Escobero e em pequenos ribeirões perto da cidade de Envigado.

Nos afloramentos da estrada Loma del Escobero, os migmatitos são compostos por quartzo, feldspato, muscovita \pm biotita no leucossoma e biotita, sillimanita e granada no melanossoma. Apresentam ainda zonas de concentração de "ninhos" de fibrolita e áreas de concentração de quartzo em boudins. Em geral os migmatitos apresentam estruturas estromáticas (Foto 10), mas estruturas dobradas (Foto 11) e nebulíticas são também observadas. Pegmatitos compostos por quartzo, feldspato, muscovita e, às vezes, turmalina e granada também são comuns nesta área.

$\mathrm{Na}$ zona da estrada Loma del Escobero, observou-se um dique de anfibolito nos migmatitos, com cêrca de $35 \mathrm{~cm}$ de espessura, não muito contínuo. Nos contatos do anfibolito com as rochas migmatíticas observam-se acumulações locais de biotita, produto da reação da intrusiva com a encaixante.

Nas proximidades de El Retiro observa-se uma reduzida ocorrência de migmatitos e granulitos e o predomínio de anfibolitos. Os anfibolitos mostram-se pouco deformados e apresentam poucas variações mineralógicas, sendo as mais importantes pequenas acumulações de biotita em alguns dos afloramentos e silicificação em outros afloramentos. Diques de composições que variam de basáltica a andesítica (Foto 12) são comuns em várias partes da área.

Os anfibolitos são as rochas mais comuns da região de El Retiro o que contrasta com a denominação da unidade como Migmatitos e Granulitos de El Retiro, definido nos trabalhos de mapeamento prévios.

Os anfibolitos afloram principalmente nas estradas La Fé-El Retiro, Don DiegoLa Ceja e La Fé-Don Diego e apresentam variações notáveis nos níveis de alteração intempérica. Muito embora as rochas possam exibir foliação marcante, com dobras isoclinais presentes em vários afloramentos, predominam rochas maciças. Variações na granulação são também observadas, mesmo na escala de afloramentos, produto não somente do metamorfismo e do tectonismo, mas também de variações granulométricas no protólito. São muito comuns afloramentos de rochas muito fraturadas, invadidas por diques de composições que variam de basálticas até andesíticas. Diques pegmatíticos são também observados em alguns afloramentos. 
Estes diques, juntamente com remobilizados félsicos que englobam minerais máficos sugerem que os anfibolitos foram também afetados pela migmatização regional. Zonas de cisalhamento comumente cortam estas rochas, resultando em faixas repetitivas de milonitos.

Petrograficamente ocorrem anfibolitos sensu stricto, anfibólio xistos e anfibolitos milonitizados, todos compostos principalmente por anfibólio e plagioclásio, com quantidades variáveis de biotita e quartzo. A biotita concentra-se em bandas em alguns dos afloramentos de rochas foliadas, com contatos gradacionais, indicando introdução metassomática de potássio ao longo de descontinuidades planares relacionadas com a xistosidade regional e/ou com a foliação milonítica. Porfiroclastos de quartzo também são comuns em alguns dos afloramentos cisalhados, podendo ser o quartzo de origem hidrotermal ou assimilado de rochas ácidas.

Também ocorrem intercalados nos anfibolitos, quartzitos usualmente miloníticos, com granada e quantidades variáveis de muscovita, e quartzo-sericita xistos quase sempre intensamente milonitizados, mas afloramentos com rochas mais preservadas e quartzitos fracamente foliados são encontrados localmente. O grau de intemperismo é intenso nesta área, muitas vezes dificultando a identificação das rochas originais. Veios pegmatíticos quartzo-feldspáticos com muscovita são comuns, geralmente muito intemperizados, e diques de diabásio alterados, de cor vermelha, também são observados em alguns afloramentos. 


\section{PETROGRAFIA}

Os litotipos que ocorrem na região de Medellín-Caldas-El Retiro podem ser divididos em dois grupos principais. O primeiro deles compreende um conjunto de muscovita-quartzo xistos (Xistos de Ancón), anfibólio xistos com intercalações de biotita xistos (Anfibólio Xistos de Caldas), com ocorrência rara de estaurolita e, em menor proporção, ortognaisses (Gnaisse de La Miel) que, localmente, preservam as relações de contato indicativas de terem sido granitos intrusivos nos anfibólio-granada xistos. $O$ segundo grupo é representado por migmatitos e granulitos com anfibolitos e gnaisses associados (Anfibolitos, Migmatitos e Granulitos de El Retiro).

As principais unidades litotípicas reconhecidas são:

\subsection{Anfibólio Xistos de Caldas}

Petrograficamente as rochas que correspondem a este corpo são compostas principalmente por anfibólio (>60\%), granada (10-20\%) quartzo (5-10\%) e biotita ( $\sim 5 \%)$. Os outros minerais $(10-15 \%)$ comumente encontrados na maioria das amostras analisadas são: plagioclásio, epidoto-clinozoisita, sericita, clorita, calcita, apatita, ilmenita (na maioria das vezes com borda de leucoxênio, devida ao retrometamorfismo) e, mais raramente titanita, rutilo e magnetita. Normalmente, estes minerais subordinados podem ser produto de reações retrometamórficas ou hidrotermais. Somente nas amostras 13b e 18 foram observados alguns cristais de zircão. Em geral, as amostras apresentam uma textura porfiroblástica de matriz nematoblástica e raramente granonematoblástica.

$O$ anfibólio (petrograficamente hornblenda) apresenta um ângulo $C^{\wedge} Z$ entre $16^{\circ}$ e $20^{\circ}$ e pleocroísmo constante em quase todas as lâminas. A fórmula pleocróica é dada por $\mathrm{X}=$ verde-oliva, $\mathrm{Y}=$ amarelo muito claro e, às vezes, amarelo-esverdeado e $\mathrm{Z}=$ verde-azulado na maioria das lâminas; $X=$ verde, $Y=$ amarelo-esverdeado e $Z=$ verde nas lâminas $\mathrm{M} 3$ e $18 \mathrm{~b}$ e $X=$ verde-oliva, $Y=$ amarelo-claro e $Z=$ verde-claro nas lâminas 6 e 7. O anfibólio mostra-se quase sempre bem orientado, definindo uma textura nematoblástica $\left(S_{n}\right)$ da rocha (Foto 13) e também está incluso na granada (Foto 14). Os cristais são na maioria subidioblásticos e, raramente, apresentam zonamento óptico, com núcleos mais claros envolvidos por uma porção mais pleocróica e uma tênue borda menos pleocróica por sua vez recoberta por outra zona mais pleocróica, indicando desequilíbrio metamórfico, com fase inicial de cristalização em 

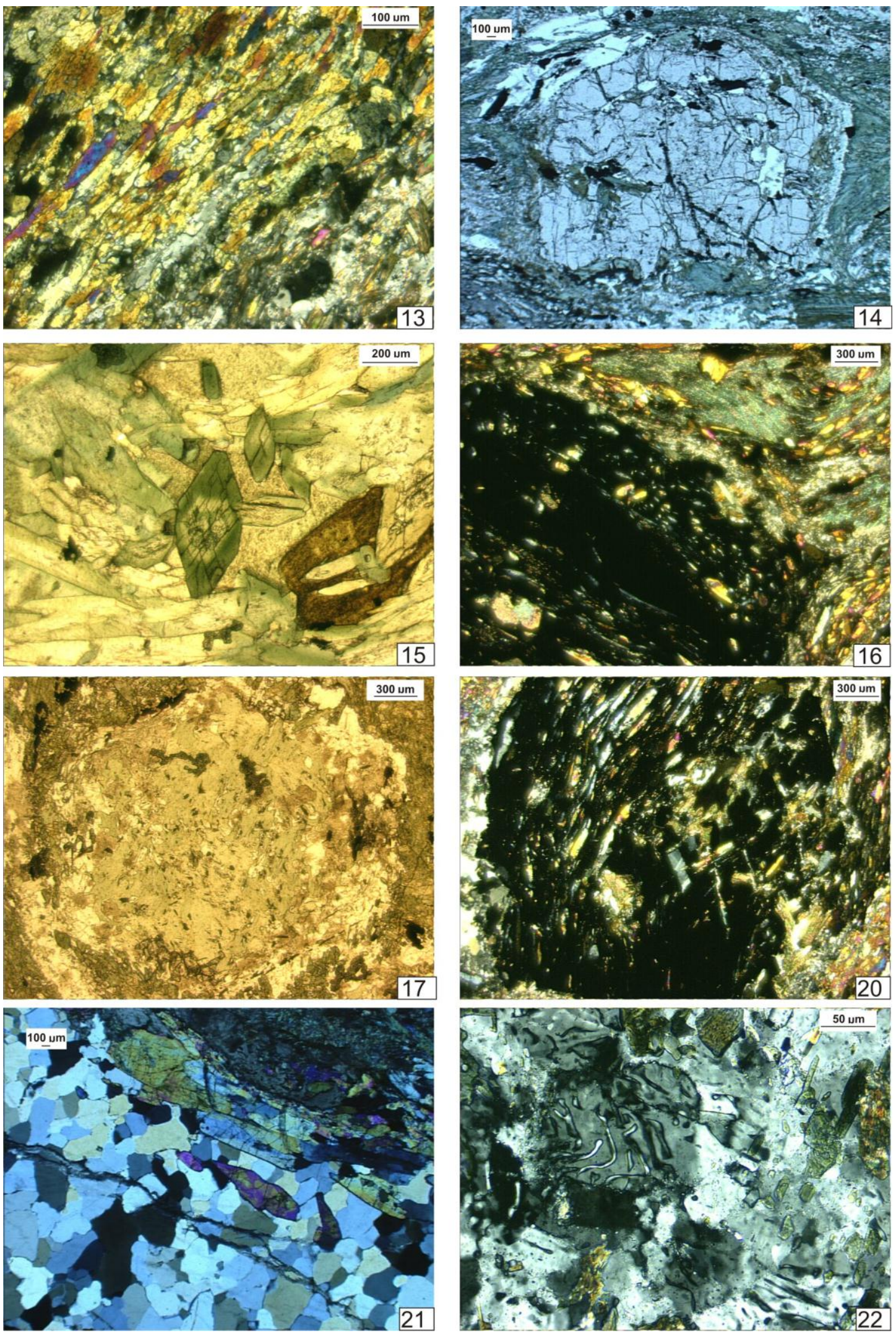

13 Xistosidade (textura nematoblástica) definida pelo anfibólio em anfibolito da unidade de Anfibolitos, Migmatitos e Granulitos de El Retiro. 14 Inclusão de anfibólio em granada em anfibolio xisto da zona de Caldas. 15 Anfibólio com intenso zonamento marcado pela variação na cor em anfibólio xisto da zona de Caldas. 16 Inclusões de biotita, epidoto-clinozoisita em granada em anfibólio xisto da zona de Caldas. 17 Substituição de granada por clorita (pseudomorfo) em anfibólio xisto da zona de Caldas. 20 Inclusão de plagioclásio geminado em granada em anfibólio xisto da zona de Caldas. 21 Quartzo em foliação e inclusão junto com epidoto-clinozoisita em anfibólio xisto da zona de Caldas. 22 Textura mirmequítica em anfibólio xisto da zona de Caldas. 
menor grau, que grada para maior grau e uma fase final retrometamórfica ou de remetamorfismo (Foto 15). Arcos poligonais são raramente observados, mas em algumas lâminas apresentam-se como parte da $S_{n}$ dobrada, indicando a existência de uma deformação mais antiga e um aquecimento final em regime estático.

A granada ocorre geralmente como porfiroblastos com diâmetros variando entre 0,8 e 7,0 mm, que apresentam inclusões orientadas $\left(S_{i}\right)$ de quartzo, epidotoclinozoisita, anfibólio, plagioclásio, ilmenita, e mais raramente biotita e rutilo, caracterizando a $S_{i}$ discordante da foliação externa (Foto 16), indicando a existência de pelo menos duas fases deformacionais. Em geral observam-se sombras de pressão nos porfiroblastos, causadas pelo desenvolvimento da $S_{n}$. Comumente são observadas texturas de instabilidade nas bordas da granada, com dissolução retrometamórfica, ou substituição parcial ou completa, às vezes em uma mesma lâmina por clorita (Foto 17), como nas lâminas $15 \mathrm{~h}$ e $15 \mathrm{i}$ indicando, possivelmente, diferentes razões fluido retrometamórfico - rocha, canalizados na xistosidade. Em amostras nas quais é possível a determinação de uma história deformacional mais complexa, observam-se a cristalização acretiva de uma nova granada que engloba os cristais alongados, resultando em cristais arredondados subidioblásticos e xenoblásticos. Geralmente a granada apresenta uma grande quantidade de inclusões, às vezes orientadas segundo a foliação principal $\left(S_{i} \| S_{e}\right)$ da rocha, mas em algumas amostras as inclusões apresentam-se dobradas, evidenciando o desenvolvimento de uma xistosidade anterior a $S_{n}\left(S_{n-1}\right)$ como é observado na Foto 18. Algumas sombras de pressão estão rotacionadas (Foto 19), o que pode indicar o desenvolvimento de uma foliação $S_{n+2}$, reorientada segundo uma $S_{n+3}$, que também gera sombras de pressão, a qual se relaciona com a foliação milonítica $\left(S_{m}\right)$ que se observa na maioria das amostras.

O plagioclásio raramente apresenta geminação e, usualmente, concentra-se nas bordas da granada como cristais xenoblásticos e em algumas das lâminas mostram hábito subidioblástico. Apenas alguns cristais apresentam-se inclusos nos porfiroblastos de granada (Foto 20). Substituições parciais até totais retrometamórficas por sericita são também comuns

O quartzo apresenta-se comumente incluso na granada ou orientado na foliação principal $S_{n}$ (Foto 21). Em geral, os cristais são xenoblásticos e em várias lâminas observam-se dissoluções com formas de golfo. A extinção ondulante é comum na maioria dos cristais, mesmo que ela não seja muito forte. Também ocorre como delgados veios pouco deformados e como parte das sombras de pressão nos 

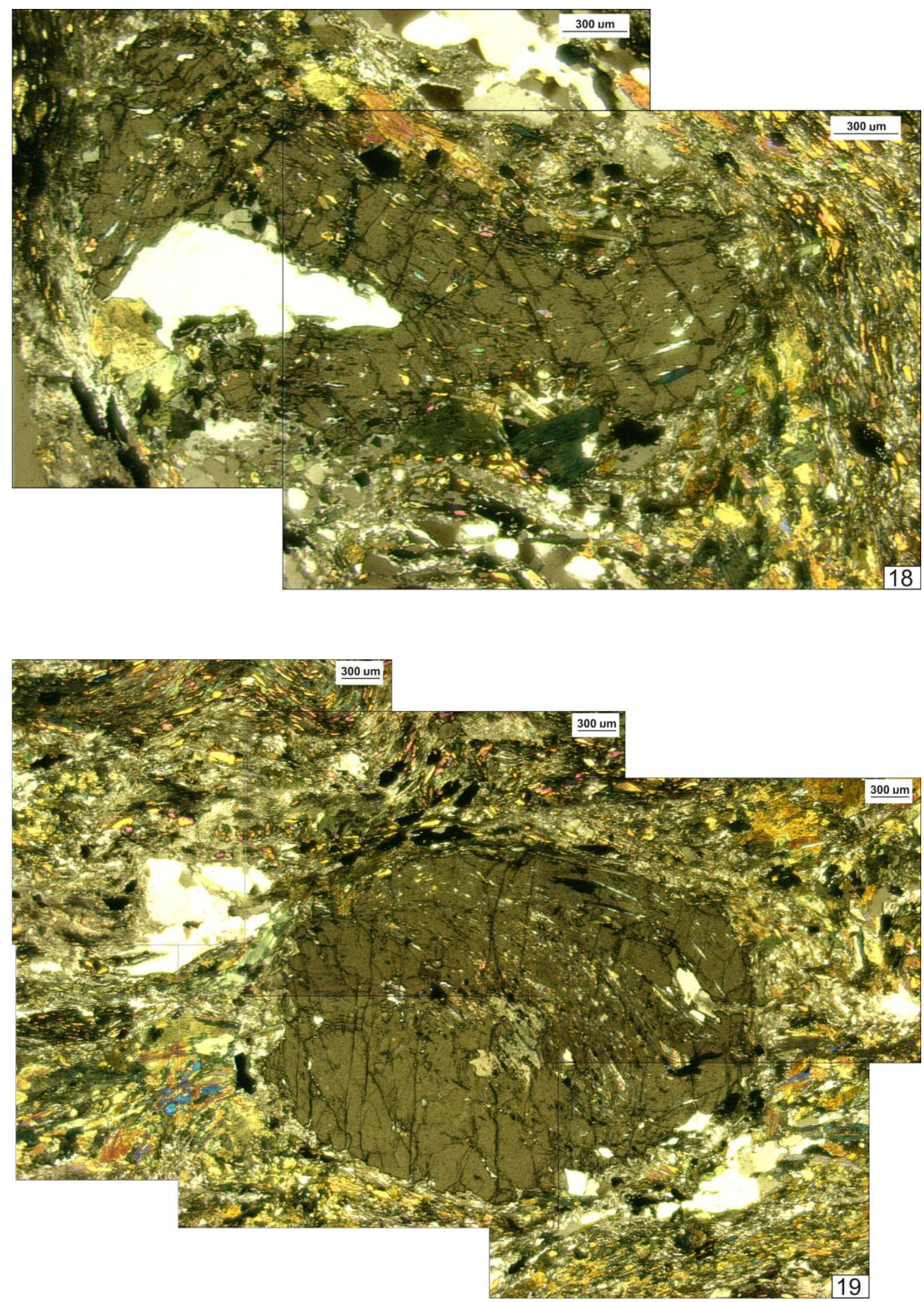

18 Inclusões em granada definindo a foliação em anfibólio xisto da zona de Caldas. 19 Sombras de pressão rotacionadas em anfibólio xisto da zona de Caldas. 
porfiroblastos de granada. Nas lâminas 13b e 20b, inclusões vermiformes de quartzo no plagioclásio compõe a textura mirmequítica (Foto 22).

A biotita apresenta pleocroísmo constante na maioria das lâminas, sendo $X=$ amarelo-claro, $\mathrm{Y}=$ marrom-esverdeado ou marrom e $\mathrm{Z}=$ marrom-escuro. Os cristais são subidioblásticos e, na maioria das lâminas, fazem parte da foliação principal $S_{n}$, mas também podem ser observados como inclusões em granada e acumulados nas bordas deste mineral, onde foram, em parte, cristalizados retrometamorficamente. Substituições parciais ou totais por clorita também são comuns, devida ao retrometamorfismo em baixo grau, e substituição por óxidos de ferro originadas pelo intemperismo também ocorrem em algumas amostras.

Como minerais subordinados, distribuídos em quantidades variáveis nas lâminas analisadas, ocorrem:

Epidoto-clinozoisita apresenta-se como cristais subidioblásticos na maioria dos casos seguindo a foliação milonítica $\left(S_{m}\right)$ das rochas, indicando que as condições metamórficas durante o cisalhamento foram menores que a do metamorfismo regional, chegando a ser compatível com a fácies xisto verde. Quando inclusos nos porfiroblastos de granada, apresentam-se orientadas e dobradas sendo parte de $S_{n-1}$, podendo, nas maioria das amostras, serem relíquias da fase de menor grau do metamorfismo progressivo. Na lâmina $15 \mathrm{~h}$ constituem um delgado veio posterior a todas as foliações da rocha, que pode ser relacionado a eventos hidrotermais finais.

A clorita apresenta-se como rosetas (Foto 23) e como pseudomorfo de granada, biotita e em algumas lâminas de anfibólio xisto.

Sericita ocorre como produto da substituição parcial e, às vezes, total de cristais de plagioclásio, normalmente acumulado nas bordas dos porfiroblastos de granada.

A calcita apresenta-se normalmente como agregados amorfos e na maioria das lâminas apresenta lamelas de deformação. A presença deste mineral não é constante em todas as lâminas, mas indica a presença de $\mathrm{CO}_{2}$ na fase fluida de parte dos eventos metamórficos.

Apatita foi observada nas lâminas 7,13b, 13c e 20b, nas quais constitui cristais idioblásticos associados aos veios de quartzo.

Ilmenita ocorre como cristais idioblásticos disseminados nas lâminas e também como inclusões em granada. Na maioria das vezes apresenta uma borda de leucoxênio, gerada durante o retrometamorfismo.

A titanita com hábito idioblástico foi observada apenas em algumas das 

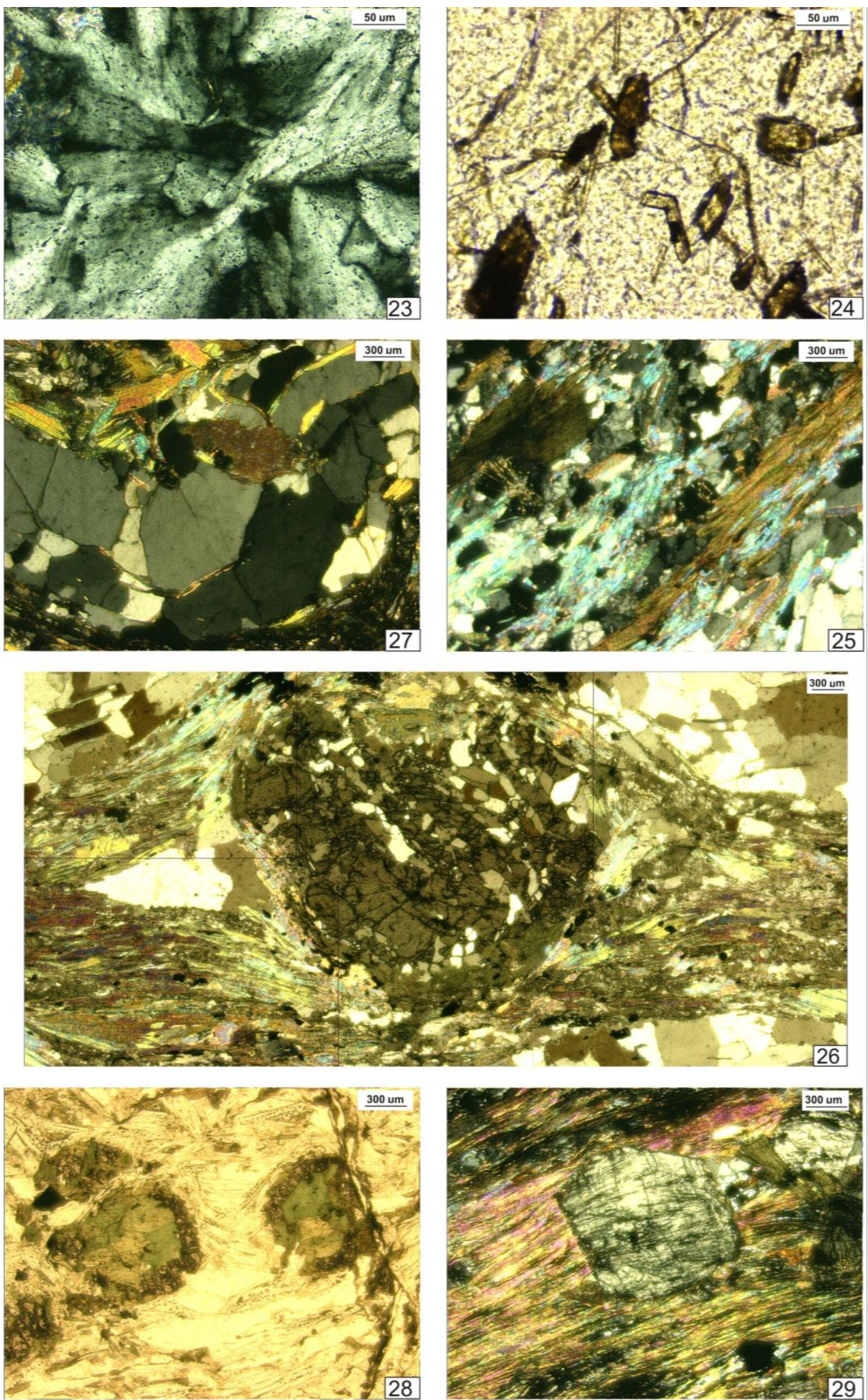

23 Clorita em rosetas em anfibólio xisto da zona de Caldas. 24 Inclusão de rutilo em granada em anfibólio xisto da zona de Caldas. 25 Textura lepidoblástica definida por muscovita e biotita em quartzo muscovita xisto da unidade dos Xistos de Ancón. 26 Sombras de pressão e inclusões de quartzo em granada em quartzo muscovita xisto da unidade dos Xistos de Ancón. 27 Dobramento de veio de quartzo em quartzo muscovita xisto da unidade dos Xistos de Ancón. 28 Substituição de granada por clorita em quartzo muscovita xisto da unidade dos Xistos de Ancón. 29 Estaurolita pós- $S_{n}$ com inclusões de grafita em biotita xisto com da unidade dos Xistos de Ancón. 
amostras analisadas.

O rutilo ocorre apenas incluso nos porfiroblastos de granada (Foto 24) e a magnetita encontra-se disseminada em algumas das amostras como cristais idioblásticos. Estes dois últimos minerais são raramente observados nas amostras analisadas.

Adicionalmente, faz parte da unidade a lâmina 18, de um biotita-quartzo xisto que ocorre intercalado nos anfibólio xistos. Esta rocha composta, em essência, por quartzo, biotita e estaurolita, com plagioclásio, granada, muscovita, zircão, apatita, ilmenita, titanita, clorita e sericita subordinados. A rocha apresenta textura lepidoblástica definida por biotita e, às vezes, acompanhada por muscovita. Raramente apresenta textura granolepidoblástica definida pelo arranjo de biotita, muscovita e quartzo. Mirmequita, pseudomorfos de clorita em biotita e de sericita em plagioclásio também são observados.

Já a lâmina 20, de outra rocha inserida na unidade, corresponde a um aplito composto principalmente por quartzo, plagioclásio, epidoto-clinozoisita, clorita e calcita. A rocha encontra-se localmente cisalhada sendo o quartzo o mineral mais afetado, apresentando-se alongado e com uma forte extinção ondulante. A calcita apresenta lamelas de deformação e a clorita mostra-se como pseudomorfo de biotita.

\subsection{Xistos de Ancón}

As amostras estudadas foram coletadas em afloramentos distribuídos ao longo da unidade e, assim sendo, suas características petrográficas serão agrupadas a seguir em subconjuntos:

Petrograficamente, as rochas da área de Caldas (córregos La Miel, La Romera e La Tablacita) são muscovita-quartzo xistos com quantidades variáveis de granada e biotita e, mais raramente, com estaurolita. As rochas apresentam textura lepidoblástica definida pelas micas (Foto 25) e, às vezes, granolepidoblástica, em função dos maiores teores de quartzo. Arranjos poligonais de quartzo, textura mirmequítica, sombras de pressão (Foto 26), kink bands em biotita são também comuns na maioria das lâminas.

As rochas são compostas por quartzo (50-60\%), muscovita (20-30\%), granada $(<5 \%)$ e minerais subordinados $(\sim 10 \%)$, como biotita, clorita, epidoto-clinozoisita, estaurolita, ilmenita, pirita, plagioclásio, apatita e sericita.

O quartzo encontra-se como cristais xenoblásticos e, mais raramente, subidioblásticos, comumente concentrados em leitos, às vezes dobrados (Foto 27). 
Também ocorre incluso, ou em sombras de pressão da $S_{n}$ em porfiroblastos de granada. Quando incluso na granada, pode definir uma foliação $S_{i}$ retilínea no núcleo dos cristais. A extinção ondulante é comumente observada na maioria dos grãos.

A muscovita apresenta-se como cristais subidioblásticos e xenoblásticos, alguns deles dobrados e, às vezes formando bandas kink e concentrado nas bordas da granada. O quartzo e a muscovita (às vezes biotita) definem a foliação principal da rocha $S_{n}$.

A granada apresenta-se como cristais subidioblásticos, raramente porfiroblásticos e, em muitas lâminas, com uma grande quantidade de inclusões e substituições retrometamórficas por biotita e/ou clorita. A granada pode apresentar zonamentos, definidos por um núcleo de cristalização pós- $S_{\mathrm{n}-1}$, envolvido por uma zona com inclusões de diversos minerais, principalmente de quartzo, e bordas mais pobres em inclusões, que podem mostrar relações microestruturais indicativas de cristalização sin- $S_{n}$ (Foto 26). Sombras de pressão assimétricas ricas em quartzo também são comumente observadas, o que confirma a cristalização tardia durante 0 desenvolvimento da $S_{n}$. As bordas mostram-se comumente corroídas e substituídas por biotita e/ou clorita, mas em alguns casos, apenas o núcleo apresenta-se completamente substituído por clorita (Foto 28), indicando zonamentos químicos, provavelmente tendo a granada inicial (pós- $S_{n-1}$ ) composições menos magnesianas que a borda, o que sugere uma progressão do metamorfismo do núcleo para as bordas, seguido pelo retrometamorfismo em baixo grau. Na lâmina $15 f$ é possível observar-se a substituição parcial até total da granada por clorita, controlada pela foliação $S_{n}$, indicando variações significativas na relação fluido/rocha durante o retrometamorfismo, devido à canalização em descontinuidades causadas pela $S_{n}$. Alguns grãos apresentam-se totalmente substituídos por quartzo e epidoto-clinozoisita, sendo que na lâmina 70 este processo está mais bem representado.

A biotita ocorre em quantidades variáveis nas amostras deste grupo, sendo que as maiores concentrações são encontradas nas lâminas 68 e 70, as quais são muscovita-biotita-quartzo xistos. Em geral a biotita apresenta pleocroísmo $X=$ marrom, $\mathrm{Y}=$ amarelo-claro e $\mathrm{Z}=$ marrom. Os cristais são xenoblásticos e subidioblásticos. A biotita mostra-se orientada segundo a $S_{n}$ e, na maioria das amostras os cristais estão substituídos parcialmente por clorita, não sendo raras substituições quase totais. Deformações superpostas geram em alguns grãos kink bands.

Complementam a composição mineralógica: 
Clorita, a qual, na maioria das amostras é produto da substituição de granada e biotita, muitas vezes resultando em pseudomorfos de ambos minerais.

Epidoto-clinozoisita encontram-se disseminados nas lâminas, formando cristais com hábito subidioblástico e concordantes com a foliação principal. Em algumas amostras podem ser importantes componentes das inclusões na granada.

Estaurolita foi observada apenas nas lâminas 45b, $45 \mathrm{f}$ e 46c, onde ocorre como cristais idioblásticos pós- $S_{n}$, ricos em inclusões de quartzo e biotita lineares, especialmente na lâmina 45b. Inclusões de grafita e alguns opacos podem também ser importantes e, tal qual para os minerais anteriores, mostram continuidade entre a $S_{i}$ e a $S_{e}$, evidenciando cristalização pós- $S_{n}$ (Foto 29). Estas texturas são também indicativas de que o pico térmico, já na fácies anfibolito, deu-se após o desenvolvimento da $S_{n}$. $O$ evento retrometamórfico é caracterizado por substituições de sericita e clorita, principalmente nas bordas dos cristais.

O plagioclásio foi observado em poucas amostras e, geralmente, não tem geminação bem desenvolvida. Comumente estão saussuritizados e sericitizados, impossibilitando sua classificação petrográfica. Na lâmina 46, pequenos cristais subidioblásticos estão disseminados (Foto 30) e petrograficamente correspondem a $\mathrm{An}_{35}$.

A sericita é, em geral, produto da substituição do plagioclásio nas rochas nas quais esta presente e também nas bordas de estaurolita.

A ilmenita apresenta-se na maioria das lâminas como cristas idioblásticos e subidioblásticos, com formação de leucoxênio nas bordas e, às vezes, substituídos quase completamente (Foto 31). Alguns desses cristas apresentam-se inclusos em biotita, sugerindo cristalização por exsolução de titânio da biotita de mais alta temperatura, em função de reequilíbrios retrometamórficos.

Também ocorre pirita disseminada em algumas das amostras $(16,68)$, sempre com hábito idioblástico e como uma fina linha de geração de óxidos de origem intempérica nas bordas.

Apatita foi observada em algumas das lâminas, na maioria das vezes como pequenos cristais arredondados disseminados.

Excepcionalmente, observou-se uma acumulação glomeroblástica de turmalina na lâmina 70 (Foto 32).

Na petrografia das amostras da área de Sabaneta, foram encontradas algumas diferenças mineralógicas em relação às da área de Caldas, apesar dos litotipos serem 

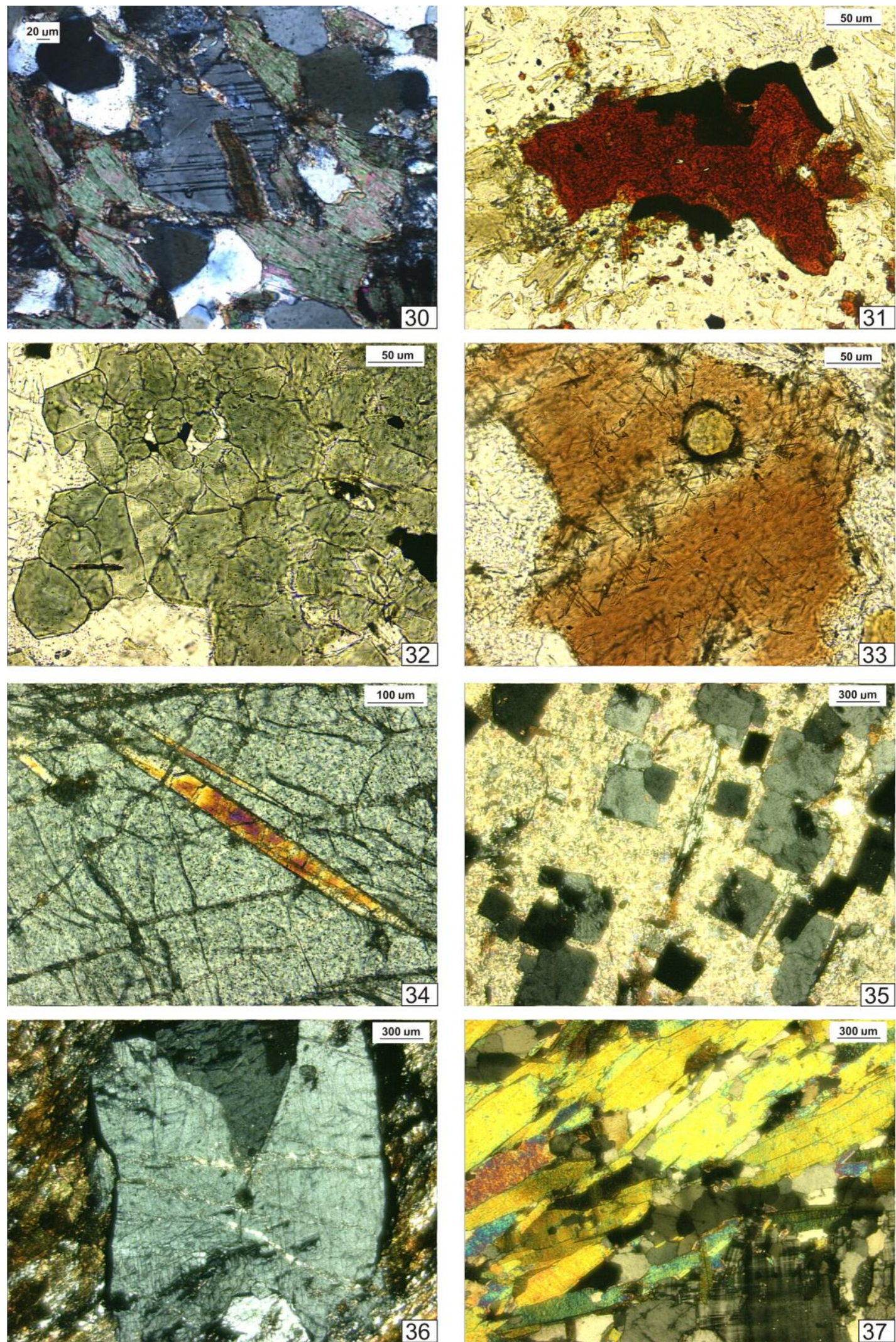

30 Plagioclásio geminado, característica rara de observar nestas rochas em biotita xisto da unidade dos Xistos de Ancón. 31 Substituição de ilmenita por leucoxênio em quartzo muscovita xisto da unidade dos Xistos de Ancón. 32 Textura glomeroblástica de turmalina biotita xisto da unidade dos Xistos de Ancón. 33 Biotita com exsolução de agulhas de ilmenita e inclusão de turmalina em biotita xisto da unidade dos Xistos de Ancón. 34 Inclusão de sillimanita em andalusita em biotita xisto da unidade dos Xistos de Ancón. 35 Andalusita de origem térmica substituindo chiastolita anteriormente substituída por sericita em grafita biotita xisto da área de El Boquerón. 36 Andalusita idioblástica pós- $S_{n}$ em grafita biotita xisto da área de El Boquerón. 37 Textura lepidoblástica definida por muscovita no Gnaisse de La Miel. 
classificados como muscovita-quartzo xistos e muscovita-biotita xistos. A textura é lepidoblástica, definida por muscovita, biotita e, às vezes, pode ser granolepidoblástica, definida por muscovita, biotita e quartzo. As rochas são compostas principalmente por quartzo, biotita e muscovita e como minerais subordinados ocorrem sericita, clorita, andalusita, turmalina, granada, sillimanita, plagioclásio, zircão, clinozoisita, apatita, ilmenita e magnetita.

O quartzo ocorre como cristais disseminados em grãos xenoblásticos isolados em porções mais micáceas, ou mostra-se orientado, estirado e com extinção ondulante na xistosidade, onde as concentrações são maiores. Também ocorre incluso em andalusita e, na lâmina 60b, compõe um delgado veio pós- $S_{n}$.

A biotita apresenta-se como cristais subidioblásticos e xenoblásticos, usualmente orientados segundo a foliação principal. Cristais de biotita são também encontrados inclusos em andalusita. O pleocroísmo é $X=$ laranja-claro, $Y=$ marromavermelhado e $Z$ = marrom-avermelhado. Alguns cristais apresentam inclusões de muscovita, quartzo, zircão, o qual gera um forte halo pleocróico, e, mais raramente de turmalina. Em algumas lâminas, como a 60, observam-se claramente agulhas de ilmenita inclusas na biotita (Foto 33). Alguns grãos apresentam uma leve substituição por clorita ao longo dos planos de clivagem.

A muscovita mostra-se subidioblástica e xenoblástica e também faz parte da foliação, muito embora possa também estar acumulada nas bordas da andalusita ou disseminada na rocha. Alguns grãos apresentam desenvolvimento de kink bands.

A sericita somente não esta presente na lâmina 58. Nas demais amostras preenche as fraturas da andalusita. Também se distribui nas bordas de cristais de andalusita ou substitui o plagioclásio.

A clorita não esta presente na lâmina 60 , mas nas demais geralmente associase aos planos de clivagem da biotita, sendo então produto de substituição retrometamórfica. Alguns grãos de biotita estão completamente substituídos por clorita, formando texturas pseudomórficas.

A andalusita encontra-se como porfiroblastos fortemente fraturados e com substituição por sericita nas fraturas e nas bordas. Apresentam inclusões de quartzo, ilmenita e biotita e, na lâmina 59, ocorrem inclusões de sillimanita (Foto 34).

A sillimanita é sempre da variedade fibrosa, mas hábito idioblástico por der observado em algumas seções basais. Ocorre disseminada na rocha ou inclusa em cristais de andalusita. 
A turmalina apresenta-se com hábito idioblástico ou subidioblástico e distribuise disseminadamente nas rochas mas, em algumas amostras, ocorre também inclusa em biotita, indicando a existência de pelo menos dois eventos de cristalização, um prée outro pós- $S_{n}$. Na lâmina 60 observa-se cerca de $5 \%$ de turmalina, sugerindo ter sido a amostra afetada por hidrotermalismo, possivelmente vinculado com a colocação de rochas graníticas.

A granada não é um mineral muito comum nas rochas desta área, tendo sido identificado disseminado somente nas lâminas 58 e 58b. Os grãos apresentam-se alongados paralelamente à foliação principal, mas é possível observar-se alguns cristais idioblásticos, o que pode indicar cristalização pós- $S_{n}$. Comumente mostram intensa oxidação devida ao intemperismo.

O plagioclásio em geral está intensamente substituído por sericita e não apresenta geminação bem desenvolvida, dificultando sua classificação petrográfica.

O zircão é um acessório raro nas rochas desta área, ocorrendo unicamente nas lâminas 58 e 60. Os grãos são muito finos e encontram-se disseminados ou inclusos em biotita. Neste último caso, geram um forte halo pleocróico.

A clinozoisita ocorre disseminada em pequenas concentrações de finos cristais apenas na lâmina 58 .

A apatita constitui finos cristais arredondados ou xenoblásticos disseminados na lâmina 60b.

Como minerais opacos foram identificados ilmenita e magnetita em todas as amostras desta área, sempre predominando a ilmenita sobre a magnetita. Normalmente ambos minerais são idioblásticos, ocorrem disseminados ou inclusos em biotita. Na lâmina 60 a ilmenita também constitui finas agulhas inclusas na biotita.

$\mathrm{Na}$ petrografia das rochas da área de Boquerón (amostras 48, 49, 50 e 50b) também foram observadas algumas diferenças mineralógicas em relação às de Caldas e Sabaneta, destacando-se a ausência de granada e estaurolita, o que sugere uma redução do grau metamórfico, e uma maior quantidade de grafita. Mas as rochas desta área podem ser classificadas como muscovita-quartzo xistos ou biotita xistos com grafita. A presença de chiastolita e de uma segunda geração de andalusita límpida, idioblástica, cristalizada a partir da chiastolita, indicam a existência de um evento de aquecimento, possivelmente causado por intrusões de rochas graníticas, após o evento metamórfico regional de baixo grau, responsável pela cristalização da chiastolita.

As rochas desta área são compostas por quartzo, biotita, muscovita, 
quantidades variáveis de andalusita e grafita e, como minerais subordinados, ocorrem sericita, clorita, turmalina, zircão, plagioclásio e opacos.

O quartzo forma cristais xenoblásticos com uma forte extinção ondulante, distribuídos e orientados ao longo da $S_{n}$.

A biotita apresenta pleocroísmo $X=$ amarelo muito claro, $Y=$ marromavermelhado e $Z$ = marrom-avermelhado. Os cristais são xenoblásticos, às vezes, subidioblásticos, e estão orientados, definindo a foliação principal das rochas, localmente deformadas, resultando na formação de kink bands. Na lâmina 50, encontra-se também inclusa nas duas gerações de andalusita. Usualmente mostram-se levemente substituídas por clorita e, às vezes, por óxidos de ferro gerados pelo intemperismo.

A muscovita forma cristais xenoblásticos e subidioblásticos, ocorrendo intimamente associada com a biotita, definindo a foliação principal $\left(S_{n}\right)$ da rocha.

A andalusita apresenta-se de duas formas. A primeira, da variedade chiastolita, constitui porfiroblastos subidioblásticos e fortemente substituídos por sericita (e/ou pirofilita ?). A segunda, cristalizada sobre os porfiroblastos de chiastolita, formam cristais idioblásticos que estão totalmente preservados das substituições ou alterações retrometamórficas, ocorrendo apenas na lâmina 50 (Foto 35). As amostras 48 e 49 não apresentam andalusita, mas nas demais a andalusita constitui porfiroblastos idioblásticos e subidioblásticos pós- $\mathrm{S}_{\mathrm{n}}$ (Foto 36).

A grafita tem granulação muito fina e encontra-se predominantemente disseminada concordante com a foliação $S_{n}$, mostrando variações na concentração, chegando a constituir filmes grafitosos. Também ocorre cristalizada discordante da $S_{n}$, ao longo de fraturas, ou forma bandas enriquecidas obliquas à foliação, indicando a preservação local do acamamento.

A sericita foi formada quase que exclusivamente pela substituição retrometamórfica da chiastolita, muitas vezes totalmente, resultando em texturas pseudomórficas. Nestes casos, é possível que parte, ou todos os cristais finos de mica possam ser pirofilita.

Também como produto do retrometamorfismo ocorre, mais raramente nas rochas desta área, clorita, quase sempre resultado de substituição pouco intensa da biotita.

Turmalina foi encontrada somente na lâmina 49, na qual ocorre como cristais arredondados em quantidades muito reduzidas. Nesta mesma lâmina observa-se 
também zircão muito fino, arredondado, e plagioclásio xenoblástico fino, fraturado e com a geminação dobrada, ambos em quantidades muito pequenas.

\subsection{Gnaisse de La Miel}

Petrograficamente as amostras são compostas, em essência, por feldspato potássico (às vezes microclínio), quartzo, plagioclásio, muscovita e biotita. Subordinadamente ocorrem clorita, sericita, zircão, apatita e ilmenita.

Quartzo, feldspato potássico e plagioclásio constituem entre 80 e $90 \%$ do total da rocha, sendo o quartzo, o mineral que mostra maior variação de teor (15-40\%). Apresentam poucas texturas metamórficas, mas principalmente são observadas evidências de deformação rúptil e dúctil como boudins, extinção ondulante de quartzo, cristais de plagioclásio e quartzo quebrados, geminação de microclínio dobrado e kink bands em micas. Pseudomorfos de clorita em biotita e de sericita em plagioclásio também estão presentes assim como texturas pertítica, mirmequítica e gráfica.

O quartzo é xenoblástico e sempre apresenta uma extinção ondulante intensa. Arranja-se em textura granoblástica, variando a poligonal em algumas zonas. Também ocorre incluso no feldspato potássico, definido relíquias de textura gráfica.

O feldspato potássico é xenoblástico e subidioblástico, mas, localmente constitui texturas blastoporfirítica e porfiroclástica. Podem preservar textura gráfica e, comumente mostram inversão para microclínio, com a típica geminação em grade. Parte desta inversão certamente está relacionada com a deformação em temperaturas relativamente mais baixas, como indicado pelo dobramento de alguns cristais, como na lâmina 69.

O plagioclásio $\left(\sim \mathrm{An}_{35}\right)$ é subidioblástico, xenoblástico e pode apresentar-se mirmequítico. A maioria dos cristais apresentam substituição retrometamórfica por sericita. Também são comuns como exsoluções de albita no feldspato potássico, caracterizando a existência de relíquias de texturas pertíticas.

A muscovita apresenta-se subidioblástica e xenoblástica e, normalmente não apresenta orientação preferencial, apesar de ser sempre possível a observação, na maioria das lâminas, de uma fraca foliação, definida pela incipiente orientação deste mineral, raramente constituindo textura lepidoblástica (Foto 37). Também ocorre inclusa em alguns dos grãos de feldspato potássico, provavelmente produto de sericitização retrometamórfica. Na lâmina M2, observam-se dobramentos intensos e geração de kink bands, assim como produto da substituição da biotita. 
A biotita apresenta pleocroísmo $\mathrm{X}=$ marrom-claro, $\mathrm{Y}=$ marrom e $\mathrm{Z}=$ marromescuro. Os cristais são subidioblásticos e xenoblásticos e, comumente estão parcial a totalmente substituídos por clorita. Algumas inclusões de biotita são observadas no feldspato potássico.

A clorita é sempre produto da substituição de biotita, chegando a gerar texturas pseudomórficas. Pode também constituir delgados veios, produto do hidrotermalismo associado ao retrometamorfismo.

De modo semelhante a sericita é produto, principalmente da substituição do plagioclásio e, mais raramente, do feldspato potássico.

Ilmenita xenoblástica com substituição por leucoxênio está presente em pequenas quantidades, sendo, por vezes, cortada por finos veios de clorita.

Também ocorrem em pequenas quantidades e em granulação muito fina zircão e apatita idioblásticos.

\subsection{Anfibolitos, Migmatitos e Granulitos de El Retiro}

Petrograficamente as rochas desta área são divididas em migmatitos, definidos pela estrutura macroscópica, anfibolitos e granulitos, representados principalmente por ortopiroxênio granofels. Outros litotipos associados serão descritos juntamente com as rochas com as quais se apresentam relacionados.

Os principais minerais dos migmatitos são biotita, muscovita, quartzo, plagioclásio e quantidades variáveis de granada, sillimanita e, às vezes, feldspato potássico, incluindo microclínio, identificado em uma das amostras. Dentre estes minerais, os únicos presentes em quase todas as amostras são os três primeiros mencionados. Os minerais acessórios estão relacionados no Anexo I.

A biotita é usualmente xenoblástica e subidioblástica, dependendo da deformação que as afetou, pois nas amostras com maior taxa de deformação predominam os cristais xenoblásticos. O pleocroísmo é definido segundo $X=$ amareloclaro, $Y=Z$ = marrom intenso. Em algumas lâminas o arranjo dos cristais de biotita, juntamente com muscovita e sericita, define uma textura lepidoblástica na xistosidade $S_{n}$ (Foto 38), que pode gradar, mais raramente, para nemato-lepidoblástica, em função do acúmulo de sillimanita. A biotita também ocorre com granada inclusa (Foto 39), e às vezes definindo uma foliação $S_{n-1}$.

A muscovita mostra-se texturalmente análoga à biotita e, em várias lâminas está intensamente dobrada tardiamente, tendo gerado kink bands (Foto 40). 

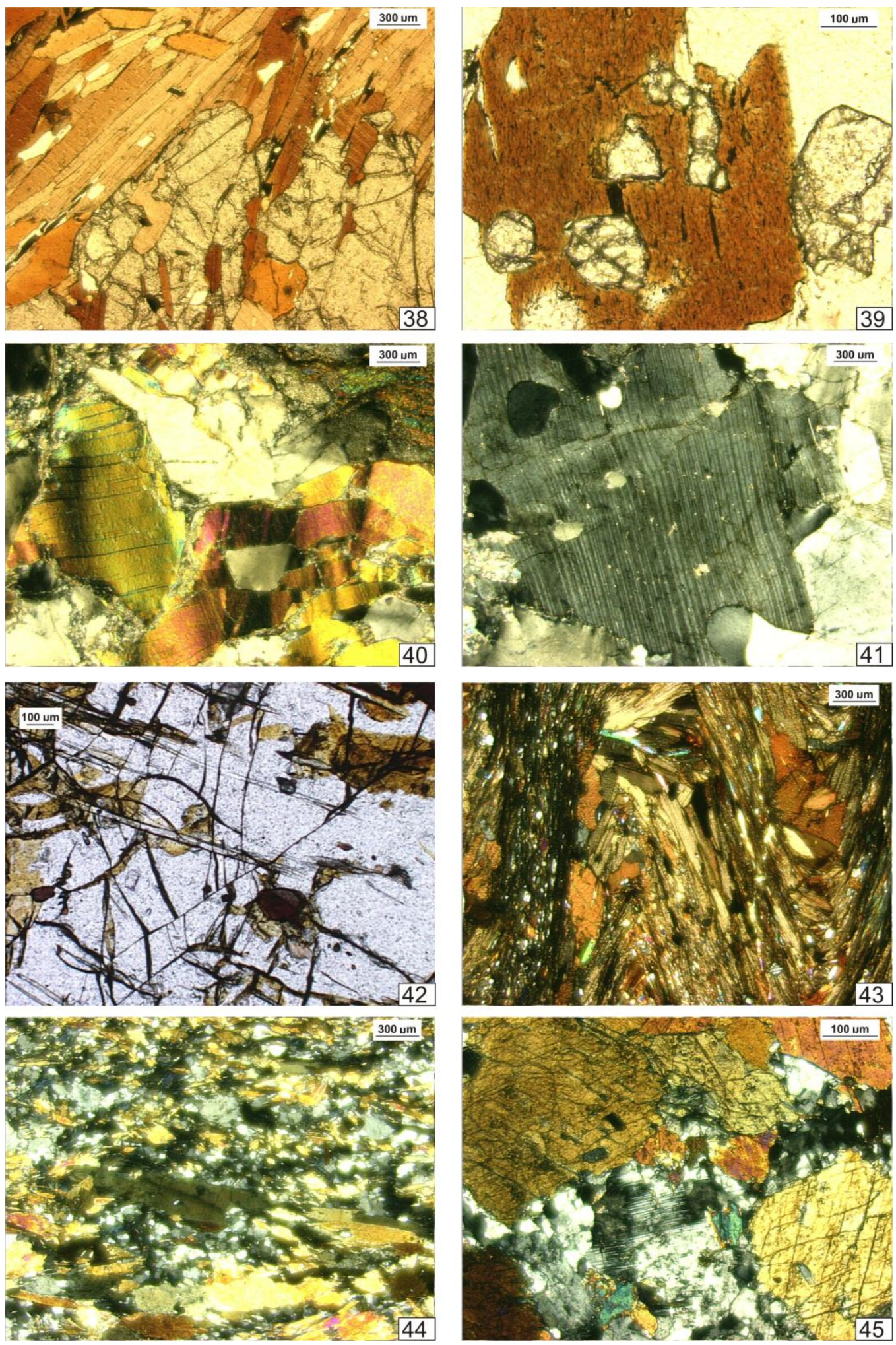

38 Textura lepidoblástica de biotita e inclusões em granada em migmatito da unidade de Anfibolitos, Migmatitos e Granulitos de El Retiro. 39 Inclusão de granada em biotita em migmatito da unidade de Anfibolitos, Migmatitos e Granulitos de El Retiro. 40 Muscovita dobrada e quartzo com forte extinção ondulante em migmatito milonitizado da unidade de Anfibolitos, Migmatitos e Granulitos de El Retiro. 41 Plagioclásio quebrado com inclusões de quartzo em migmatito milonitizado da unidade de Anfibolitos, Migmatitos e Granulitos de El Retiro. 42 Granada com inclusões de sillimanita e biotita em migmatito da unidade de Anfibolitos, Migmatitos e Granulitos de El Retiro. 43 Sillimanita na foliação $S_{n+1}$ em migmatito da unidade de Anfibolitos, Migmatitos e Granulitos de El Retiro. 44 Textura nematoblástica em anfibolitos e variação no tamanho de grão na unidade de Anfibolitos, Migmatitos e Granulitos de El Retiro. 45 Plagioclásio e anfibólio em textura granoblástica na unidade de Anfibolitos, Migmatitos e Granulitos de El Retiro. 
quartzo é sempre xenoblástico e possui extinção ondulante na maioria das amostras. Também constitui inclusões em biotita, turmalina, granada e plagioclásio.

O plagioclásio tem teores de anortita que não superam os $5 \%\left(A n_{5}\right)$, apresentase como cristais xenoblásticos, raramente, subidioblásticos e possuem, freqüentemente, inclusões de muscovita e quartzo e acumulações de óxidos nos planos de geminação. Cristais com geminação dobrada e fraturamentos (Foto 41) estão presentes em muitas das amostras deste conjunto. Normalmente os cristais apresentam geminação polissintética bem desenvolvida e, às vezes, periclinio. Normalmente mostra-se parcial a totalmente substituído por sericita.

A granada, presente na maioria das amostras, mostra-se muito fraturada e, comumente as fraturas estão preenchidas por sericita. Normalmente os cristais são xenoblásticos e, na maioria dos casos, estão alongados e deformados pela foliação $S_{n}$. Pode ser relativamente rica em inclusões de biotita, quartzo, sillimanita, muscovita e, às vezes, turmalina (Foto 42). O eixo maior do estiramento dos cristais é paralelo à foliação $S_{n}$, definida em várias amostras pelo arranjo da biotita e muscovita.

A sillimanita ocorre na variedade fibrolita ou forma cristais prismáticos idioblásticos alongados. Neste último caso, em várias das lâminas, orienta-se segundo a $S_{n}$ mas também é observada na $S_{n+1}$ (Foto 43 ). Inclusões deste mineral em granada são comuns.

O feldspato potássico é também xenoblástico e tem características muito parecidas como as descritas para o plagioclásio.

Dentre os minerais subordinados, o zircão e a monazita encontram-se na maioria dos casos inclusos em biotita e a turmalina na granada ou disseminada pela rocha. Em sua maioria são cristais idioblásticos e subidioblásticos.

A sericita é retrometamórfica, tendo sido cristalizada a expensas do plagioclásio, ou da muscovita, orientando-se segundo a $S_{n}$ neste caso.

O epidoto-clinozoisita são produto da substituição de plagioclásio e a clorita da biotita.

Apatita está presente na maioria das amostras, mas na lâmina 54c tem granulação mais grossa, alcançando até $5 \mathrm{~mm}$ de comprimento, e os cristais são idioblásticos. Nas demais amostras seu tamanho não supera $1 \mathrm{~mm}$.

Duas das amostras desta área foram coletadas de diques encaixados em migmatitos. São anfibolitos granoblásticos compostos por hornblenda, às vezes 
zonada, (65-70\%), plagioclásio $\left(\mathrm{An}_{45}\right)(25-30 \%)$ e biotita, opacos, sericita, epidoto e titanita subordinados $(<2 \%)$.

Petrograficamente os anfibolitos, anfibólio xistos e anfibolitos milonitizados de El Retiro possuem anfibólio (60-70\%), plagioclásio (20-25\%), quartzo (5-10\%) e biotita em conteúdo variável, sendo que em algumas das amostras não há presença deste mineral. Como minerais subordinados $(\leq 5 \%)$ ocorrem titanita, clorita, apatita, clinozoisita, zircão, rutilo e ilmenita.

O anfibólio apresenta-se como cristais xenoblásticos e subidioblásticos e, às vezes, orienta-se segundo a foliação regional e/ou segundo a foliação milonítica (Foto 44). Possuem pleocroísmo que varia de $X=$ amarelo-esverdeado ou verde muito claro, $Y=$ verde-claro ou verde-oliva e $Z$ = verde-amarelado claro. Na lâmina 36 d apresentase com pleocroísmo $X=$ amarelo-claro, $Y=$ marrom e $Z=$ marrom. $O$ angulo $\mathrm{C}^{\wedge} \mathrm{Z}$ varia

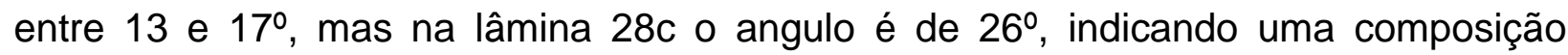
petrográfica de hornblenda. Zonamento óptico é observado em algumas das amostras, apresentando-se variações no pleocroísmo nas bordas e no núcleo dos cristais. A variação mais típica é dada por um núcleo mais pleocróico envolvido por uma zona menos pleocróica, por sua vez recoberta por outra zona mais pleocróica, indicando a existência de um evento retrometamórfico ou de re-metamorfismo em temperaturas mais baixas que afetou rochas de maior grau, seguido por um novo aquecimento final. Os anfibólios de outras amostras possuem apenas o núcleo mais pleocróico e a borda menos pleocróica, o que pode sugerir que o aquecimento final possa estar relacionado à colocação de corpos ígneos. Não são incomuns cristais geminados e inclusões de quartzo e, aparentemente, de zircão e rutilo nos anfibólios de algumas das amostras.

O plagioclásio apresenta-se subidioblástico e xenoblástico, e com geminação polissintética (Foto 45), periclínio e polissintética-Carlsbad possivelmente indicando que sejam relíquias ígneas. Sua composição varia entre $A n_{38}$ e $A n_{55}$, mas não foi possível a obtenção do teor de anortita em todas as lâminas, já que em algumas substituições por saussurita e sericita são muito intensas, em algumas lâminas. Junto com o anfibólio, o plagioclásio faz parte da textura granoblástica observada em várias das amostras da região. Zonamentos foram também observados, especialmente nas lâminas 36 e 36b, mas não foi possível determinar se é normal ou inverso.

O quartzo é sempre xenoblástico, tem extinção ondulante e ocorre disseminado nas rochas, mas, às vezes encontram-se inclusos no anfibólio. Na lâmina 28c, observam-se alguns cristais fraturados, indicando deformação em condições rúpteis. 
A biotita foi observada principalmente na lâmina 36b. Tem hábito subidioblástico e os cristais mostram-se orientados, definindo uma foliação muito fraca. O pleocroísmo é $\mathrm{X}=$ amarelo muito claro, $\mathrm{Y}=$ marrom-avermelhado e $\mathrm{Z}=$ marrom-avermelhado.

Titanita, que ocorre de modo subordinado, normalmente distribui-se nas bordas dos minerais opacos, associa-se ao anfibólio ou constitui pequenas acumulações locais. Os cristais são xenoblásticos ou arredondados, mas hábito subidioblástico e idioblástico são também observados.

A clorita é sempre produto da substituição parcial de anfibólio mais grosso, mas pode substituir totalmente os cristais finos.

A apatita apresenta-se como pequenos grãos idioblásticos e subidioblásticos disseminados nas lâminas.

A clinozoisita foi verificada apenas na lâmina 43, na qual forma pequenas acumulações e pequenos veios.

A ilmenita, em geral, está quase que totalmente substituída por leucoxênio, mas a substituição pode ser total, restando apenas pseudomorfos. O hábito dos cristais mais grossos é idioblástico e subidioblástico.

O zircão (?), assim como rutilo (?), apresentam-se como cristais finíssimos idioblásticos inclusos nos anfibólios.

Os quartzitos com granada e os quartzo-sericita xistos miloníticos que ocorrem intercalados nos anfibolitos possuem a seguinte composição: quartzo (30-50\%) e sericita (30-50\%), além de granada, muscovita, clorita, opacos, clinozoisita-epidoto, zircão e cloritóide subordinados. As variações nos teores de quartzo e sericita determinam a inclusão dos litotipos no grupo dos xistos ou dos quartzitos.

O quartzo é xenoblástico, tem extinção ondulante intensa e, na maioria das amostras os cristais estão alongados (Foto 46), formando, em alguns casos ribbons. Os contatos entre os grãos são suturados e muitos cristais estão fraturados, mas textura poligonal também é observada, assim como textura mortar. O quartzo também se concentra nas sombras de pressão assimétricas de minerais opacos, textura esta muito característica na lâmina 32c.

A muscovita constitui cristais xenoblásticos e subidioblásticos finos, sempre com sericita associada. Cristais fraturados e dobrados são observados na lâmina 32c e, assim como a sericita definindo a foliação da rocha. Esta pode ainda preencher fraturas da granada. 

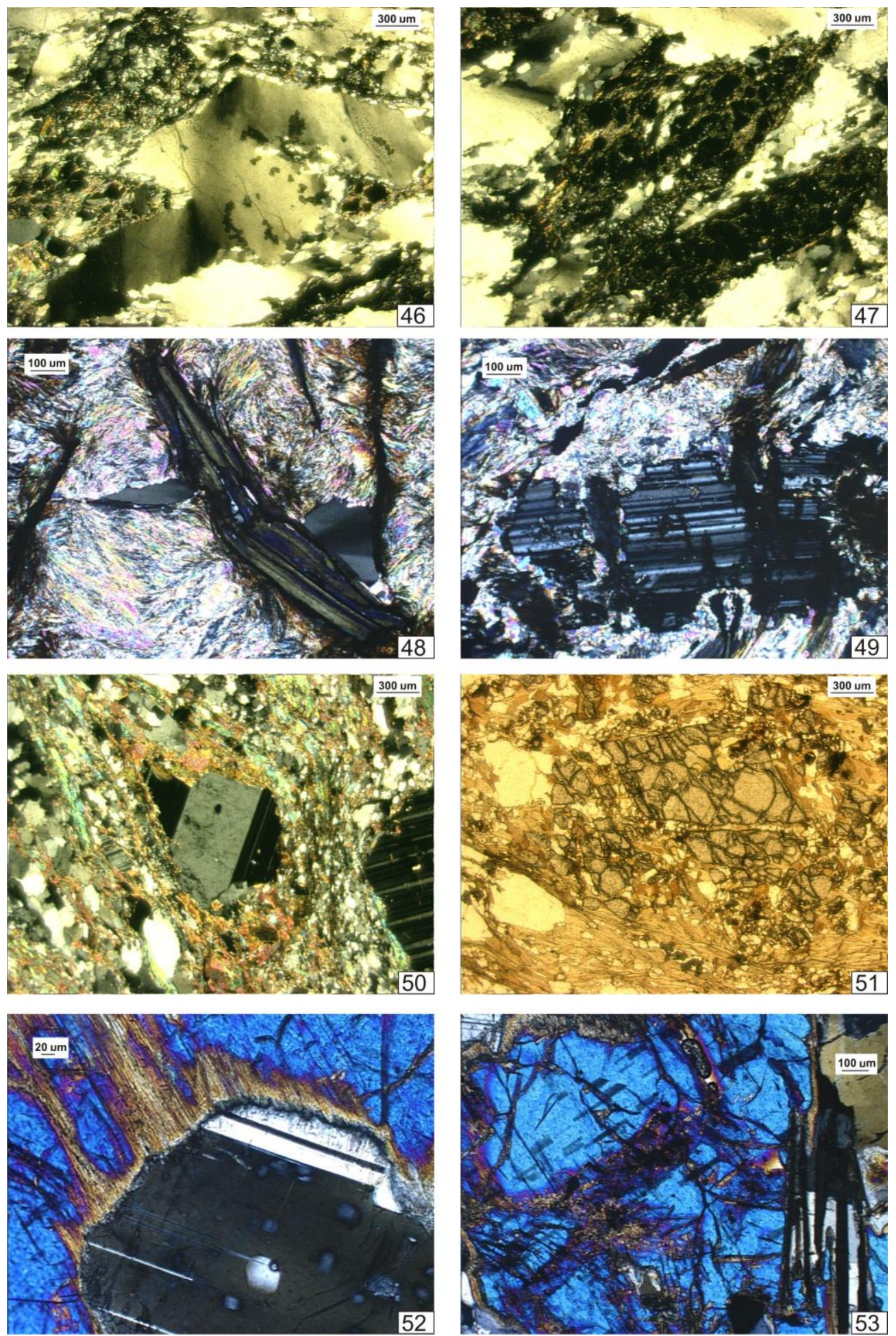

46 Extinção ondulante do quartzo intensamente deformado em quartzito milonítico da unidade de Anfibolitos, Migmatitos e Granulitos de El Retiro. $\mathbf{4 7}$ Granada xenoblástica alongada e fragmentada com sericita preenchendo as fraturas na unidade de Anfibolitos, Migmatitos e Granulitos de El Retiro. 48 Pseudomorfo de biotita em clorita cortando a foliação $S_{n}$ em sericita xisto com cloritóide da unidade de Anfibolitos, Migmatitos e Granulitos de El Retiro. 49 Cloritóide com bordas corroídas e fraturas preenchidas por sericita em sericita xisto com cloritóide da unidade de Anfibolitos, Migmatitos e Granulitos de El Retiro. 50 Porfiroclastos de plagioclásio em rochas intensamente milonitizadas da unidade de Anfibolitos, Migmatitos e Granulitos de El Retiro. 51 Porfiroclasto de granada com fibrolita, biotita e quartzo em rochas intensamente milonitizadas da unidade de Anfibolitos, Migmatitos e Granulitos de El Retiro. $\mathbf{5 2}$ Ortopiroxênio com inclusão de plagioclásio e bordas substituídas por anfibólio fibroso em granofels com ortopiroxênio da unidade de Anfibolitos, Migmatitos e Granulitos de El Retiro. 53 Ortopiroxênio com exsolução de rutilo e intercrescimento simplectítico de biotita e quartzo em granofels com ortopiroxênio da unidade de Anfibolitos, Migmatitos e Granulitos de El Retiro. 
A granada, a qual se apresenta na maioria das amostras como cristais estirados e fragmentados, pode ser substituída por clorita e, às vezes, com sericita (?) ou pirofilita (?) preenchendo as fraturas (Foto 47). Substituições por óxidos de ferro intempéricos são mais raramente apresentadas, mas na lâmina 32d são comuns.

A clorita é resultado da substituição da biotita, podendo formar pseudomorfos (Foto 48), mas também substitui a granada. Na lâmina $32 \mathrm{~d}$, agulhas de ilmenita apresentam-se inclusas nos grãos de clorita.

Minerais opacos são encontrados em muito pouca quantidade nas lâminas, podendo formar, como na lâmina 31, cristais idioblásticos finos disseminados na rocha.

Clinozoisita-epidoto foram observados apenas na lâmina 31, onde constituem cristais subidioblásticos disseminados.

Minerais de alto relevo e alta birrefringência, possivelmente zircão, são observados em pequeno volume como grãos arredondados disseminados na lâmina 32b.

O cloritóide, encontrado unicamente na lâmina 32d, apresenta-se como porfiroblastos subidioblásticos $(1-7 \mathrm{~mm})$ de cristalização posterior à foliação. Possuem fraturas preenchidas por sericita e óxidos de ferro e bordas corroídas e substituídas por sericita (Foto 49).

Outras rochas intensamente milonitizadas também intercaladas nos anfibolitos (amostras 34, 34b, 38, 41, 41b, 41f, 064A) são compostas principalmente por feldspato, biotita e quartzo e pequenas concentrações de sillimanita (?) e agregados de biotita em forma de "ninhos". Em um dos afloramentos destas rochas foi também encontrado um dique de diabásio.

Petrograficamente estas rochas possuem, em essência, plagioclásio, quartzo e biotita e, como minerais subordinados, granada, muscovita, sericita, clorita, zircão, monazita, ilmenita, sillimanita e feldspato potássico.

O plagioclásio tem conteúdos de anortita que variam de $\mathrm{An}_{37}-\mathrm{An}_{40}$, com um bom desenvolvimento da geminação polissintética e, mais raramente, periclínio e polissintética-Carlsbad. Os cristais constituem porfiroclastos com granulação variando entre 0,9 e $5 \mathrm{~mm}$ (Foto 50 ), incipientemente substituídos por sericita, especialmente nos planos das geminações. As geminações podem estar dobradas e os cristais fraturados e inclusões de quartzo também são comuns neste mineral.

O quartzo apresenta-se xenoblástico, na maioria dos casos alongado, com forte extinção ondulante, às vezes fraturado e com contatos suturados. Apresenta-se 
também como inclusões nos grãos de plagioclásio.

A biotita, forma cristais idioblásticos e subidioblásticos com pleocroísmo $X=$ amarelo-claro e $Y=Z=$ marrom-avermelhado. Na lâmina 41, além de cristais com este pleocroísmo, ocorrem também cristais com $\mathrm{X}=$ creme-claro e $\mathrm{Y}=\mathrm{Z}=$ laranja-claro. Os cristais mostram-se orientados, definindo uma textura lepidoblástica na rocha e também ocorrem como inclusões em granada e, mais raramente, plagioclásio. Localmente formam agregados, como na lâmina 41 b.

A granada mostra-se sempre estirada e fragmentada, com algumas fraturas preenchidas por clorita e, às vezes, com inclusões de quartzo. Pequenas acumulações de óxidos de ferro intempéricos são também comuns (Foto 51).

A muscovita apresenta-se comumente subidioblástica, mas pode ocorrer com forma idioblástica. Os cristais encontram-se disseminados nas lâminas, sem definir arranjos foliados.

A sericita apresenta-se, em geral, como produto de substituição retrometamórfica ou hidrotermal do plagioclásio e do feldspato potássico, mas pode também preencher fraturas da granada. Este processo gera também clorita a partir da biotita, a qual pode ser totalmente substituída.

Zircão e, possivelmente, monazita, ocorrem disseminados como cristais arredondados, e tendem a concentrar-se nas proximidades de cristais de biotita.

A ilmenita forma cristais idioblásticos aciculares ou tabulares disseminados nas lâminas e, geralmente, parcialmente substituídos por leucoxênio e/ou rutilo.

Sillimanita, observada apenas na lâmina 41, é idioblástica, com cortes basais romboédricos, ou fibrosa, e ocorre normalmente associada com a biotita, a qual agiu, para alguns cristais, como núcleos de cristalização.

O feldspato potássico somente foi encontrado nas lâminas 064A e 41, onde a textura comum é do tipo flaser. Tem hábito xenoblástico, textura micrográfica e um fraco desenvolvimento de geminação em grade. Além da substituição por sericita e exsoluções de albita, exibe evidências de deformação rúptil e dúctil,.

Dentro da rochas da fácies granulito (amostras ER2 e 854A) e associadas foram analisadas duas lâminas de amostras coletadas por outros pesquisadores em anos anteriores, uma vez que estas rochas não foram observadas em nenhum afloramento da área.

Mesmo assim, as descrições petrográficas aqui feitas concordam parcialmente com as apresentadas nos trabalhos anteriores. As lâminas ER2 e 854A são compostas 
por plagioclásio (50\%), ortopiroxênio (25 - 30\%), quartzo ( 10\%), biotita (5\%), anfibólio (5\%), zircão, ilmenita ( 1\%). As diferenças entre as duas lâminas são a presença de apatita, clorita e turmalina, presente na lâmina ER2, e feldspato potássico e monazita na lâmina 854A. Em geral, as duas amostras apresentam textura granoblástica.

O plagioclásio encontra-se na maioria das vezes xenoblástico, mas cristais subidioblásticos também são comuns. Apresentam geminação polissintética e periclínio e zonamentos concêntricos inversos em cristais não geminados, reflexo do aumento da temperatura do metamorfismo. Grãos isolados não zonados apresentam conteúdo de anortita de $A n_{68}$ na ER2 e $A n_{39}$ na 854A. Cristais com $A n_{28}$ são encontrados em ambas as lâminas, indicando a ocorrência de reequilíbrios retrometamórficos. Desenvolvimentos de mirmequitas também são observados.

O ortopiroxênio é xenoblástico, apresenta intensa substituição por anfibólio fibroso nas bordas, sendo às vezes totalmente consumido, com inclusões de plagioclásio (Foto 52). Os núcleos frescos, apresentam, em sua maioria, exsoluções de rutilo com orientação perpendicular aos planos de clivagem do mineral (Foto 53).

O quartzo é também xenoblástico, ocorre disseminado e tem uma forte extinção ondulante. Subordinadamente faz parte da mirmequita.

A biotita apresenta-se xenoblástica e subidioblástica, com um pleocroísmo $X=$ amarelo muito claro, $Y=Z=$ marrom-avermelhado. Encontra-se disseminada pela rocha, sem uma nítida orientação preferencial e, na maioria das vezes, possuem exsolução de ilmenita acicular.

O anfibólio cristalizou-se, em geral, na bordas de cristais de ortopiroxênio, do qual derivou por substituição retro- ou re-metamórfica. Localmente pode também substituir completamente o ortopiroxênio. Apresenta habito fibroso e pleocroísmo que varia de verde até quase incolor.

A ilmenita exibe diversos hábitos, como agulhas, massas irregulares concentradas nas bordas e nos planos de clivagem da biotita ou como cristais idioblásticos disseminados nas lâminas. Bordas corroídas também são comuns.

O zircão, com formas arredondadas, ocorre disseminado nas lâminas, assim como a apatita, mas este está presente apenas na lâmina ER2.

A clorita é produto da substituição retrometamórfica dos anfibólios que ocorrem nas bordas do ortopiroxênio.

Turmalina é rara em poucos cristais xenoblásticos, assim como a muscovita, mas esta última apresenta-se subidioblástica. 
Na lâmina 854A ocorre feldspato potássico xenoblástico com forte extinção ondulante e monazita arredondada e em muito pouca quantidade, além das texturas locais apresentadas em vários minerais. Nesta lâmina observa-se também um intercrescimento simplectítico de quartzo e biotita junto ao ortopiroxênio (Foto 53).

Junto com estas duas lâminas foi descrita outra de um anfibolito, o qual, segundo os trabalhos anteriores aflora na mesma área. Nesta 0 anfibólio pseudomorfisa o piroxênio (com pleocroísmo $X=$ quase incolor, $Y=$ verde-claro e $Z=$ verde-pálido; angulo $C^{\wedge} Z 2^{\circ}$ ) e o plagioclásio tem conteúdo de anortita $A n_{62}$. Estes dois minerais apresentam-se subidioblásticos e definem a textura granoblástica da rocha. Incipientes substituições de sericita no plagioclásio são observadas e o quartzo ocorre incluso no plagioclásio e disseminado na lâmina. Cristais de ilmenita incipientemente substituídos por leucoxênio também estão presentes disseminados na lâmina. 


\section{QUÍMICA MINERAL}

Foram feitas análises químicas de minerais em microssonda eletrônica em 9 amostras representativas dos litotipos com paragêneses mais adequadas aos estudos geotermobarométricos. Os resultados incluem anfibólio, plagioclásio e granada de rochas da unidade de Anfibólio Xistos de Caldas; granada, biotita, muscovita, clorita, estaurolita e plagioclásio dos Xistos de Ancón e granada, biotita, muscovita e plagioclásio de migmatito, ortopiroxênio, plagioclásio, anfibólio e biotita de rochas da fácies granulito e granada, clorita e cloritóide de sericita xisto com cloritóide da unidade dos Anfibolitos, Migmatitos e Granulitos de El Retiro. As principais características composicionais de cada uma das rochas são apresentadas a seguir:

\subsection{Anfibólio Xistos de Caldas}

O anfibólio apresenta-se subidioblástico, às vezes exibe zonamento óptico e define a foliação das rochas deste grupo. Também ocorre como inclusões em granada.

Quimicamente são, em geral, anfibólios cálcicos, destacando apenas alguns dos grãos da amostra 11c, que correspondem a anfibólios de Mg-Fe-Mn. A maioria dos anfibólios tem composição de ferro-tschermakita, tschermakita e magnésio-hornblenda, mas análises feitas na amostra 11c, indicam composição próxima à da cummingtonita, segundo a classificação de Leake et al. (1997), com conteúdos de Si muito próximos de 7\% (Figura 7).

Nas amostras 11c e 12c os anfibólios têm composições muito homogêneas para $\mathrm{Mg}, \mathrm{Ca}$ e $\mathrm{Na}$, apresentando somente leves variações nos conteúdos de Al e Fe. Estas variações não se mostram relacionadas com zonamentos ou clivagens, mas podem ser devidas à substituições retrometamórficas pouco intensas, ou à presença de minerais inclusos nas proximidades.

$\mathrm{Na}$ seção 20b foram feitos perfis composicionais em cristais de anfibólio que apresentam fortes zonamentos ópticos que confirmam serem eles devidos às variações na composição química. De modo geral os grãos de anfibólio exibem redução do conteúdo de $\mathrm{Mg}$ nas bordas, sugerindo diminuição da temperatura do núcleo para a borda. O Na, Ca e Al mostram-se relativamente enriquecidos nas bordas, especialmente o Al. No caso do $\mathrm{Fe}$, este se apresenta enriquecido no núcleo, no entanto, apresenta dois pontos intermediários nos quais o seu conteúdo diminui, seguido de um novo aumento nas bordas acompanhado do empobrecimento em $\mathrm{Mg}$, sugerindo duas etapas de crescimento. 
A

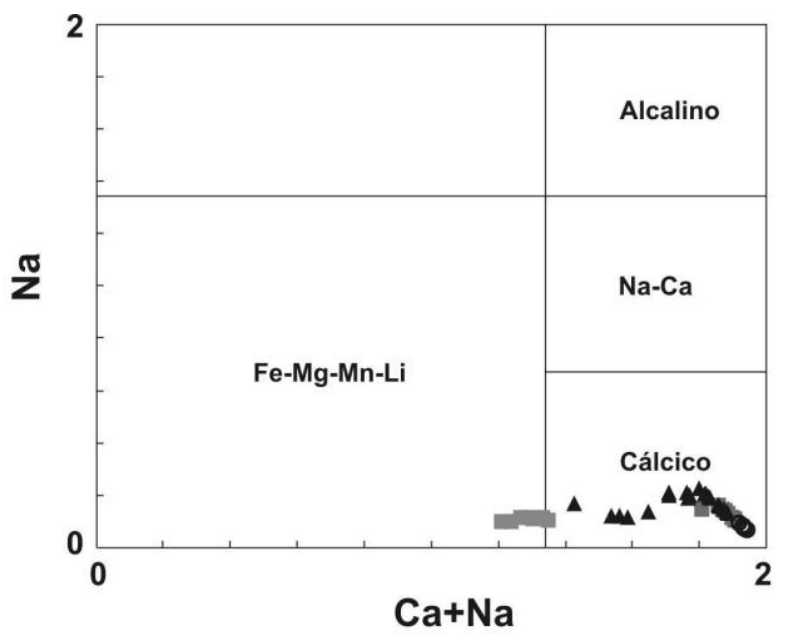

B
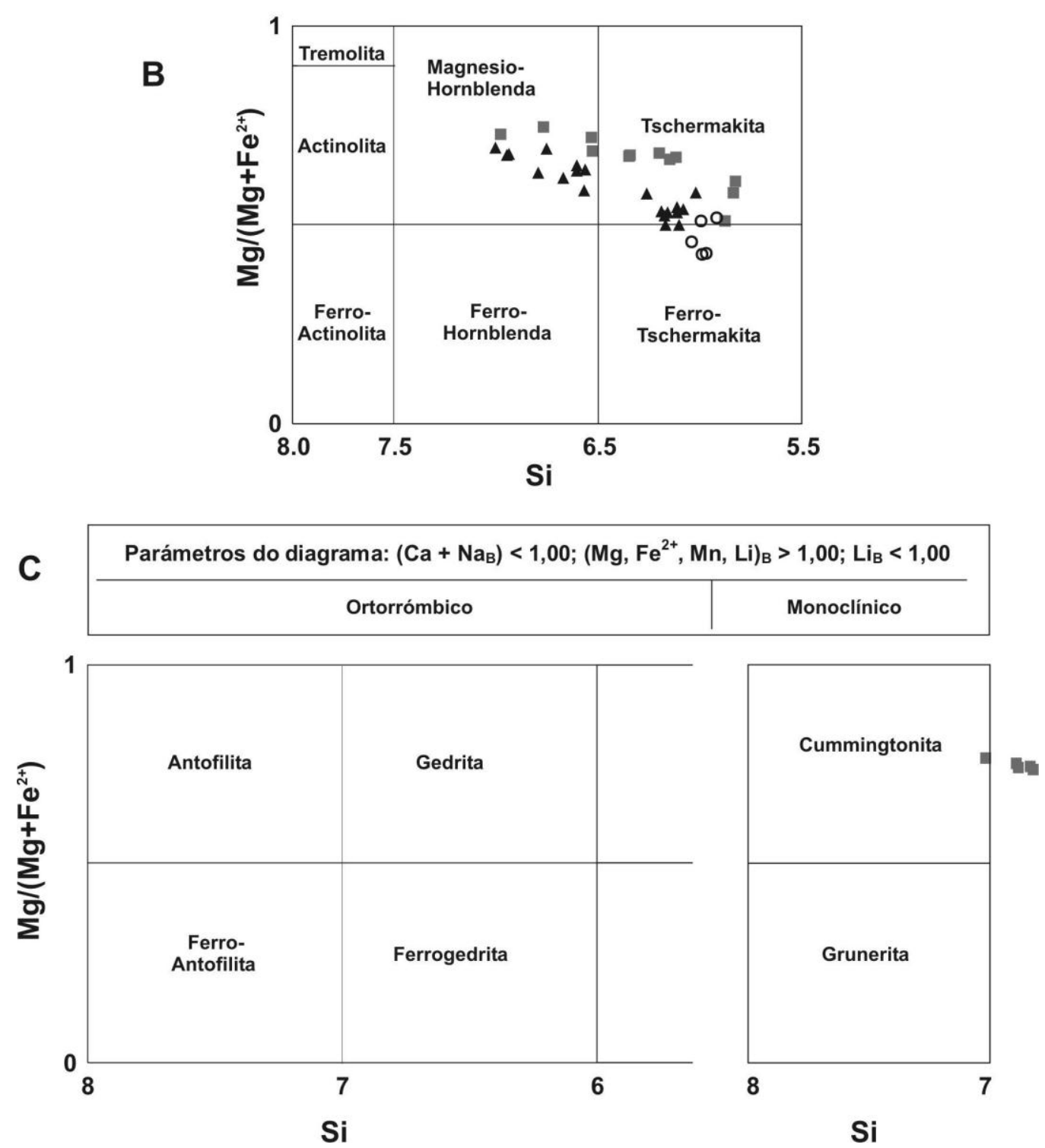

Figura 7. Classificação química dos anfibólios presentes nas seções analisadas dos Anfibólio Xistos de Caldas. (A) Diagrama de classificação dos quatro principais grupos de anfibólios, (B) diagrama de classificação dos anfibólios de Fe-Mg-Mn-Li e (C) Diagrama de classificação dos anfibólios cálcicos. Os quadrados representam as análises feitas na amostra 11c, os círculos na amostra 12c e os triângulos na amostra 20b. Classificação segundo Leake et al., (1997). 
Nas amostras desta área pode-se verificar a existência de substituição tschermakítica predominantemente nos anfibólios, com uma pequena contribuição da substituição pargasítica. Entretanto, na amostra 12c parece ter havido, a despeito do número relativamente pequeno de análises, apenas a substituição tschermakítica (Figura 8).
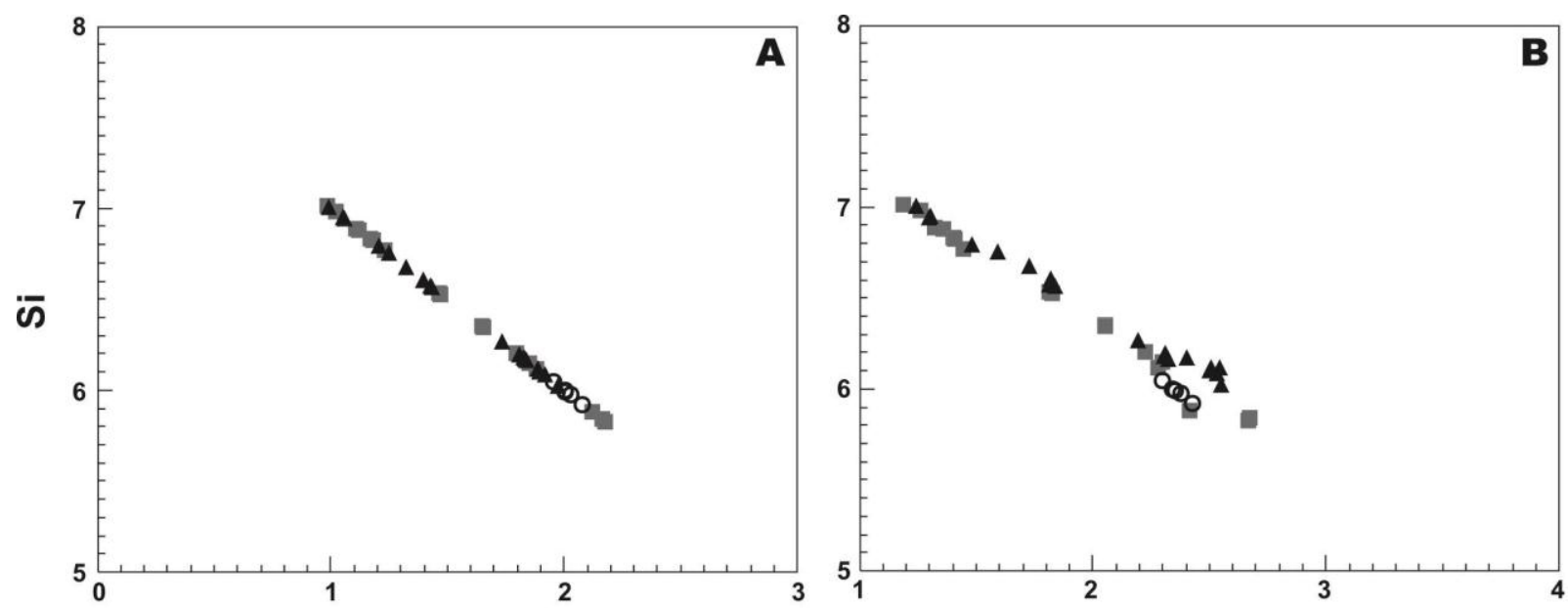

Al
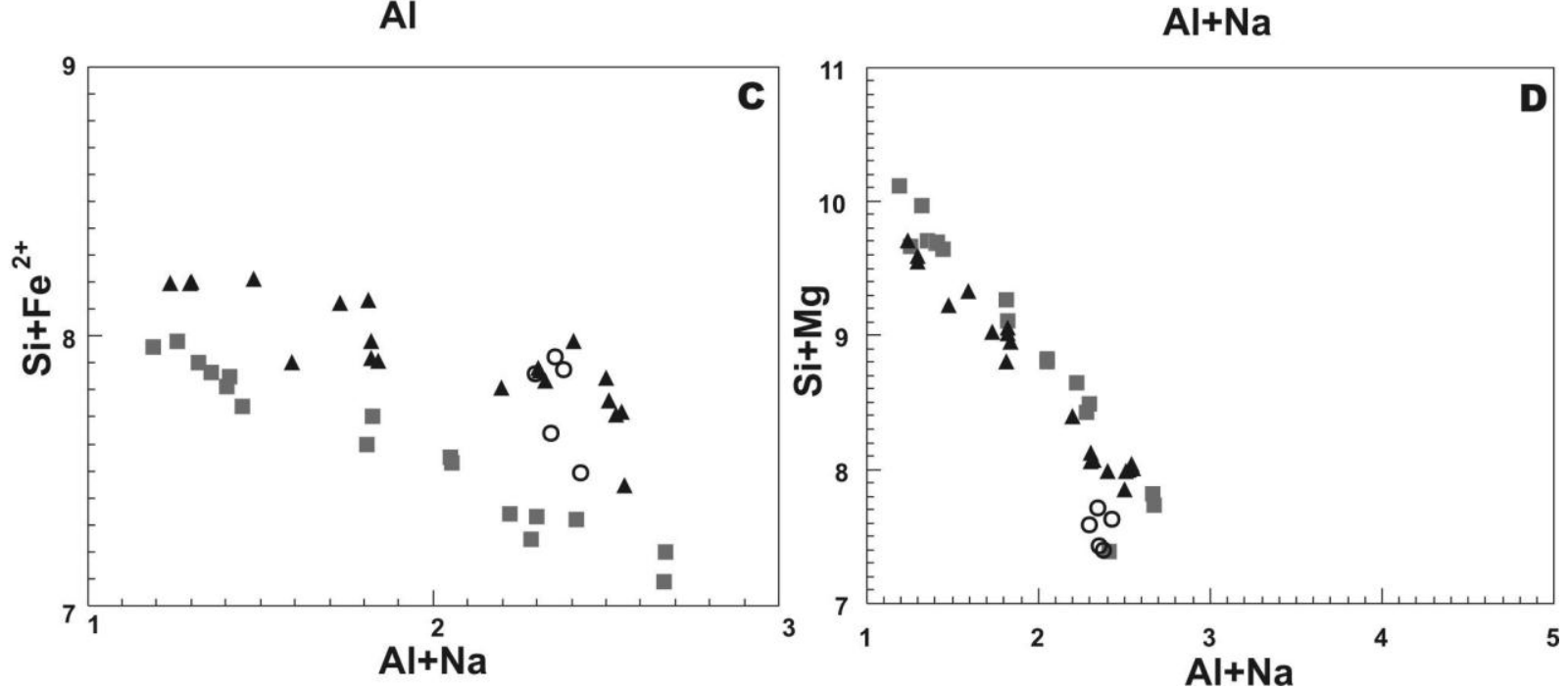

Figura 8. Substituições tschermakítica (A), edenítica (B), Fe-pargasítica (C) e Mg-pargasítica (D) nas amostras dos Anfibólio Xistos de Caldas. Os quadrados representam as análises feitas na amostra 11c, os círculos na amostra 12c e os triângulos na amostra 20b.

A granada ocorre como porfiroblastos xenoblásticos e subidioblásticos, com uma grande quantidade de inclusões (e.g. quartzo, epidoto-clinozoisita, ilmenita) e registrando a historia deformacional das rochas desta área. A composição química da granada das amostras analisadas são de composição almandínica com conteúdos menores de grossulária, piropo e espessartita (figura 9). As variações dos conteúdos de cada um dos componentes para as seções 11c e 12c pode ser expressa: almandina $(34,17-75,31 \%)$, grossulária $(15,79-34,81 \%)$, piropo $(4,86-11,38 \%)$ e espessartita $(0,16$ - 
4,62\%). As granadas da seção $20 b$ apresentam variações em cada um de seus componentes mais leves as quais podem ser expressas assim: almandina $(63,96$ $67,62 \%)$, grossulária $(24,49-28,70 \%)$, piropo (4,28-5,18\%), espessartita $(1,47-3,08 \%)$.

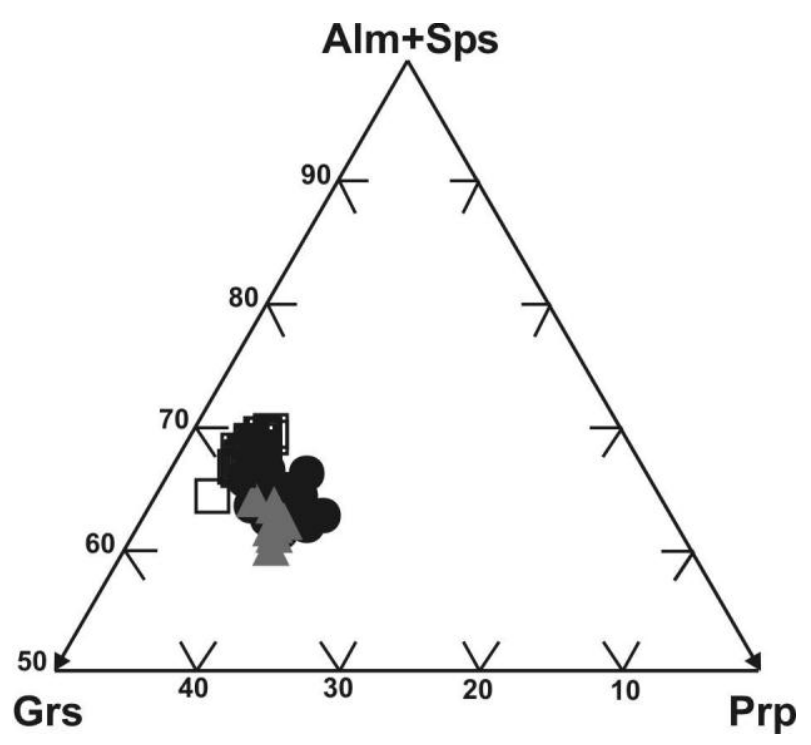

Figura 9. Composições das granadas em termos de almandina + espessartita (Alm+Sps), piropo (Prp) e grossulária (Grs) nos Anfibólio Xistos de Caldas. Os círculos correspondem aos cristais analisados nas amostra 11c, os triângulos à amostra 12c e os quadrados à amostra $20 \mathrm{~b}$.

Zonamentos suaves são observados nos perfis feitos em vários cristais de granada de cada uma das lâminas, mas diferenças nos padrões definidos em cada uma delas, notadamente quanto às distribuições de Fe e Ca, são observadas. O Mg e o Mn distribuem-se de modo muito semelhante em todos os cristais da amostra 11c, com redução dos teores de $\mathrm{Mn}$ nas bordas e enriquecimento no núcleo, inversamente ao observado com o Mg, indicando que a cristalização deu-se sob aumento das condições térmicas. A Figura 10a representa um perfil de granada em um cristal da lâmina 11c, na qual se observa que a distribuição do Fe apresenta dois pontos de inflexão, sendo um de menor concentração situado perto do núcleo e o outro num ponto intermediário, mais próximo à borda do cristal, definindo claramente um evento metamórfico progressivo e outro retrógrado. O Ca apresenta comportamento oposto ao do Fe, de tal forma que o ponto de inflexão com maior conteúdo situa-se junto ao núcleo e o de maior concentração perto da borda. Outro cristal da mesma lâmina (figura 10b), o Fe e o Ca apresentam comportamentos mais irregulares que o cristal anterior, possivelmente devido a reequilíbrios químicos tardios, sendo que o $\mathrm{Fe}$ apresenta três pontos de maior e pelo menos três pontos de menor concentração deste 
elemento. Outro grão da lâmina 11c (figura 10c), o Fe apresenta uma distribuição muito homogênea, mas em dois pontos perto da borda, apresenta-se uma inflexão negativa e uma positiva, definindo uma diferença com o resto dos pontos do perfil. O Ca apresenta também dois pontos de inflexão perto da borda, mas com caraterísticas opostas ao comportamento do Fe.

$\mathrm{Na}$ amostra 12c, foi feito um perfil em um cristal de granada o qual apresenta distribuição no conteúdo de $\mathrm{Mn}$ e $\mathrm{Mg}$ relativamente homogêneo apresentando um leve aumento no conteúdo de Mn nas bordas (Figura 11a). No caso do Ca apresentam-se leves enriquecimentos nas bordas e o resto homogêneo. $O$ ferro também apresenta um comportamento muito homogêneo, mas em uma das bordas observa-se uma diminuição bem marcada.

$\mathrm{Na}$ amostra 12c foi feito um perfil em um cristal de granada o qual apresenta distribuição no conteúdo de $\mathrm{Mn}$ e $\mathrm{Mg}$ relativamente homogêneo, apresentando um discreto aumento no conteúdo de Mn na borda (Figura 11a). Já o Ca mostra suaves enriquecimentos apenas nas bordas, sendo o restante do cristal bastante homogêneo. O Fe também exibe um comportamento muito homogêneo, mas em uma das bordas observa-se uma diminuição bem definida dos seus teores.

Com os cristais de granada da lâmina 20b foram feitos dois perfis composicionais (Figuras $11 \mathrm{~b}$ e 11c). No primeiro cristal desta lâmina o $\mathrm{Mg}$ apresenta suaves enriquecimentos nas bordas e o Mn apresenta um leve enriquecimento no núcleo. O Ca mostra uma distribuição relativamente homogênea, estando empobrecido nas bordas e com um ponto de inflexão positivo perto do núcleo do cristal. Inversamente ao $\mathrm{Ca}$, o $\mathrm{Fe}$ apresenta leves enriquecimentos nas bordas e um ponto de inflexão negativo perto do núcleo. No segundo cristal da mesma seção, o Mg apresenta leves empobrecimentos no núcleo. Por outro lado, o Mn apresenta um comportamento muito homogêneo, aumentando levemente os conteúdos desde uma borda até a outra, indicando ter havido forte controle no zonamento químico pelos minerais presentes na matriz da rocha. O Fe distribui-se homogeneamente em uma metade do cristal e, a partir do ponto de inflexão, seu conteúdo aumenta, mas sua distribuição mantem-se homogênea. O Ca apresenta uma distribuição inversa ao Fe. 

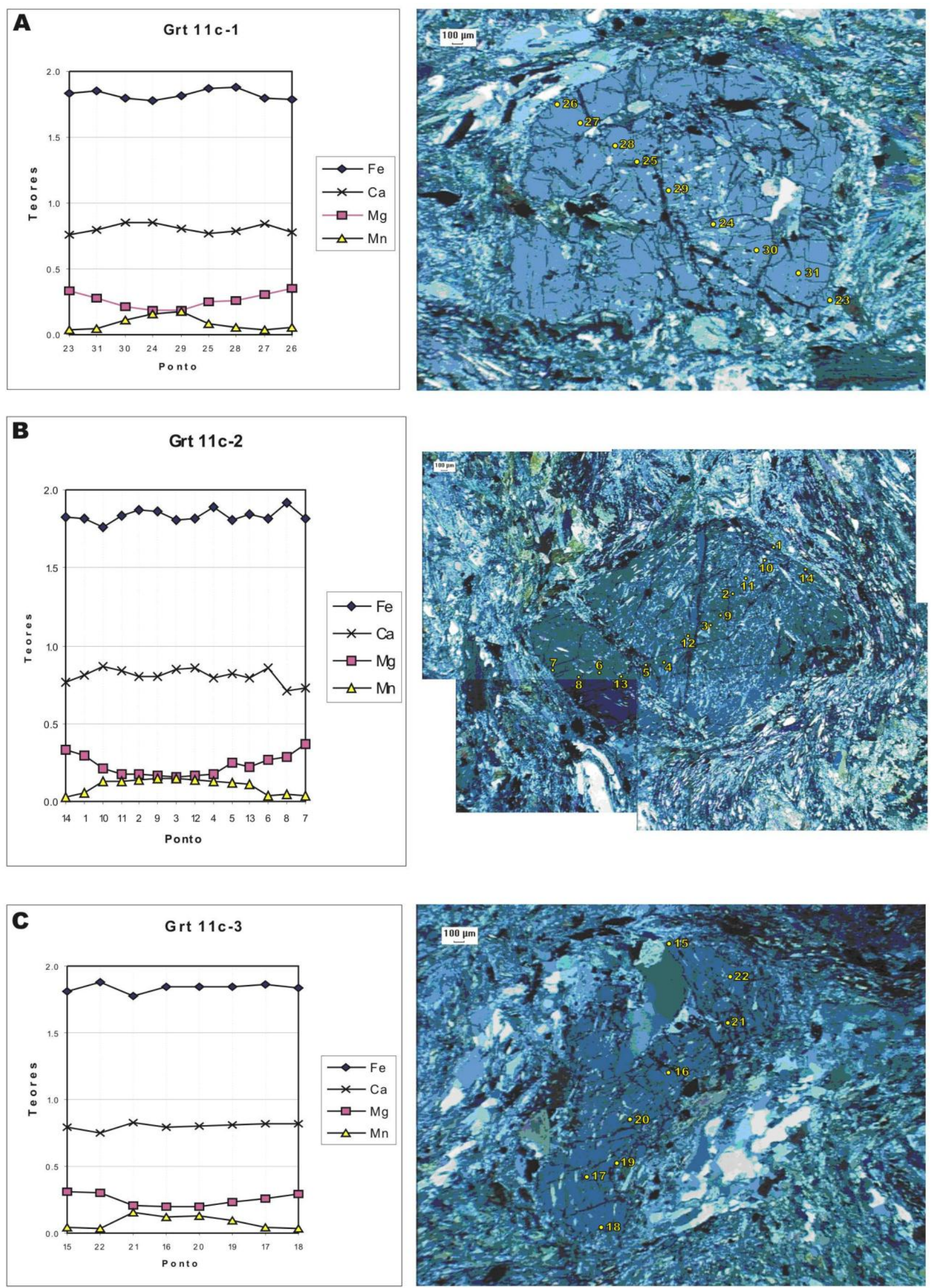

Figura 10 (A, B, e C). Perfis composicionais em granada da amostra 11c e fotos com os pontos nos quais foram feitas as análises. 

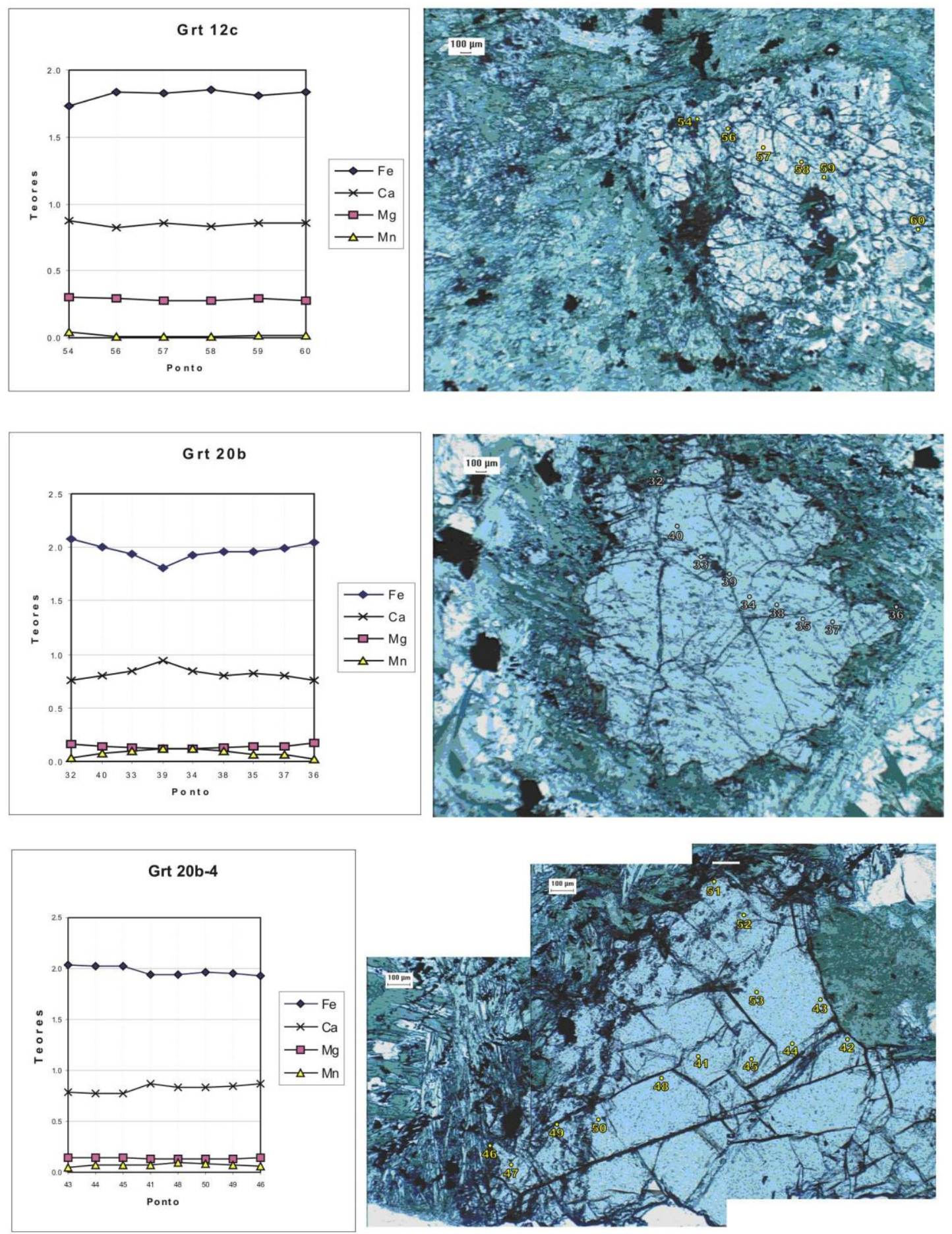

Figura 10 (A, B, e C). Perfis composicionais em granada das amostra 12c (A) e 20b (B e C) e fotos com os pontos nos quais foram feitas as análises.

A composição química do plagioclásio apresenta amplas variações no conteúdo de anortita nas seções 11c e 12c, fruto de reequilíbrios químicos parciais, mas há, conforme esperado, menor variação na composição química dos cristais inclusos na granada. Os cristais inclusões tem composição que variam de $A n_{25,8}$ a $A n_{31,6}$, mas alguns dos pontos apresentam conteúdos da molécula de ortoclásio (Figura 12) que podem ser produto de substituições por sericita ou micro-exsoluções antipertíticas não 
detectadas opticamente.

Em um cristal associado à borda da granada na seção 11c, o plagioclásio é albítico $\left(A n_{2,3}-A n_{6}\right)$, mas dois pontos analíticos mostram composição de andesina e oligoclásio, este último com quantidades da molécula de ortoclásio de 6,5\%, o que pode refletir restos do plagioclásio do metamorfismo progressivo em um grão quase que totalmente retrometamorfisado. Na seção 12c, os pontos analisados em um cristal perto da borda da granada apresentam variações que podem ser expressas como $A n_{33,3}-A n_{40,1}$ e da mesma forma com pontos nos quais aumentam o conteúdo de ortoclásio até ser praticamente feldspato potássico, com conteúdos de ortoclásio da ordem de $97,1 \%$, indicando claramente a ação de um metassomatismo potássico. Já na amostra 20b, o plagioclásio em paragênese com o anfibólio e minerais opacos, apresenta uma composição mais homogênea em todos os pontos analisados, revelando conteúdos de anortita de $\mathrm{An}_{21,0-30,0}$, correspondendo a oligoclásio cálcico que grada para andesina.

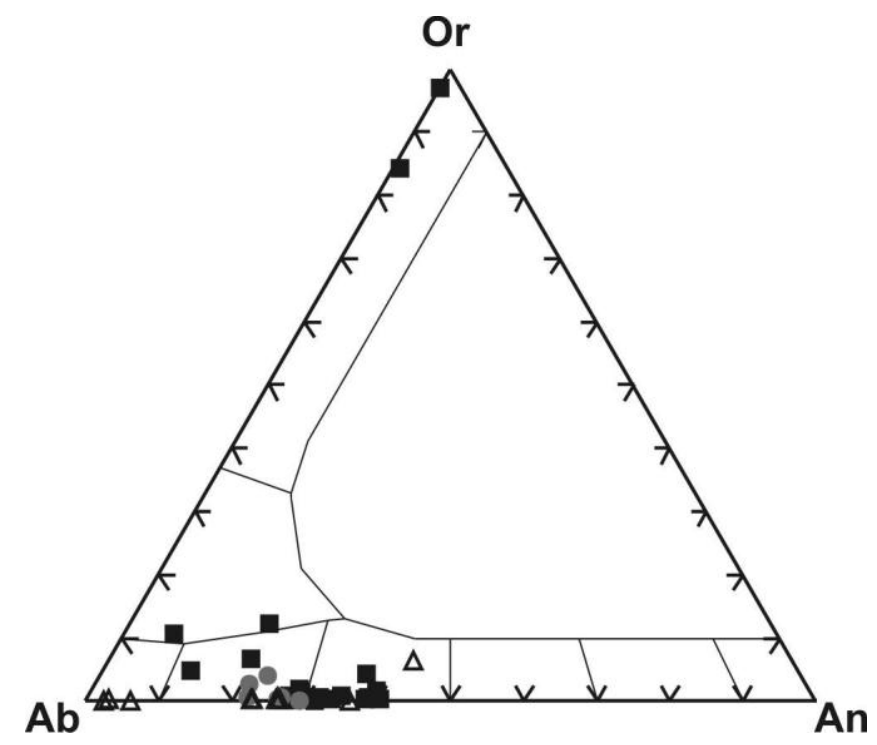

Figura 12. Diagrama de classificação do plagioclásio nas amostras dos Anfibólio Xistos de Caldas em termos de ortoclásio (Or), albita (Ab) e anortita (An). Os triângulos correspondem a cristais da amostra 11c, os quadrados à amostra 12c, e os círculos à amostra 20b.

\subsection{Xistos de Ancón}

Deste conjunto foram analisadas duas seções, das quais foram obtidos dados químicos de granada, biotita, muscovita e clorita. Além disso foram obtidos dados de estaurolita na seção 45b e de plagioclásio na seção 46.

$\mathrm{Na}$ seção $45 \mathrm{~b}$ a granada é porfiroblástica e idioblástica, com algumas 
ocorrências subidioblásticas. Apresenta poucas o nenhuma inclusão.

Quimicamente, a granada da lâmina 45b apresenta composição almandínica (Figura 13), com a seguinte variação composicional: almandina $(57,23-72,72 \%)$, espessartita (14,75-33,24\%), piropo $(4,29-7,76 \%)$ e grossulária $(4,35-5,38 \%)$. Os cristais possuem forte zonamento químico (Figura 14), com aumentos de $\mathrm{Mn}$ e Ca no núcleo, e de $\mathrm{Fe}$ e $\mathrm{Mg}$ na borda, sugerindo além da substituição de $\mathrm{Fe}$ por $\mathrm{Mg}$, importante contribuição de substituição de Fe por $\mathrm{Mn}$ em menores temperaturas, nas fases iniciais de cristalização.

Na granada da lâmina 46, foram feitas poucas análises, pois esta se apresenta muito fraturada, com muitas inclusões, principalmente de minerais opacos e, às vezes, de biotita, e fraturas preenchidas por clorita e biotita retrometamórfica. Os pontos analisados nesta amostra não correspondem a um perfil, mas permitem apresentar os valores nos quais variam cada um de seus componentes principais (Figura 15). A composição também é, em essência, almandínica, variando entre: almandina (70,9$79,65 \%)$, grossulária $(12,32-19,85 \%)$, piropo $(4,45-8,19 \%)$ e espessartita $(0-4,83 \%)$ (Figura 13).

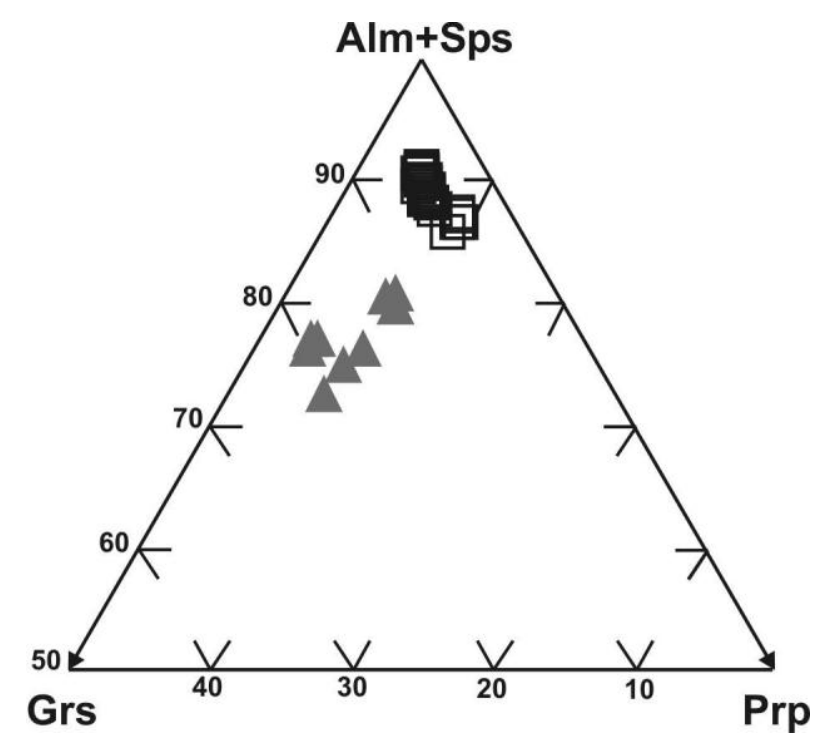

Figura 13. Composições das granadas em termos de almandina + espessartita (Alm+Sps), piropo (Prp) e grossulária (Grs) nos Anfibólio Xistos de Caldas. Os quadrados correspondem aos cristais analisados na amostra $45 \mathrm{~b}$ e os triângulos à amostra 46 . 

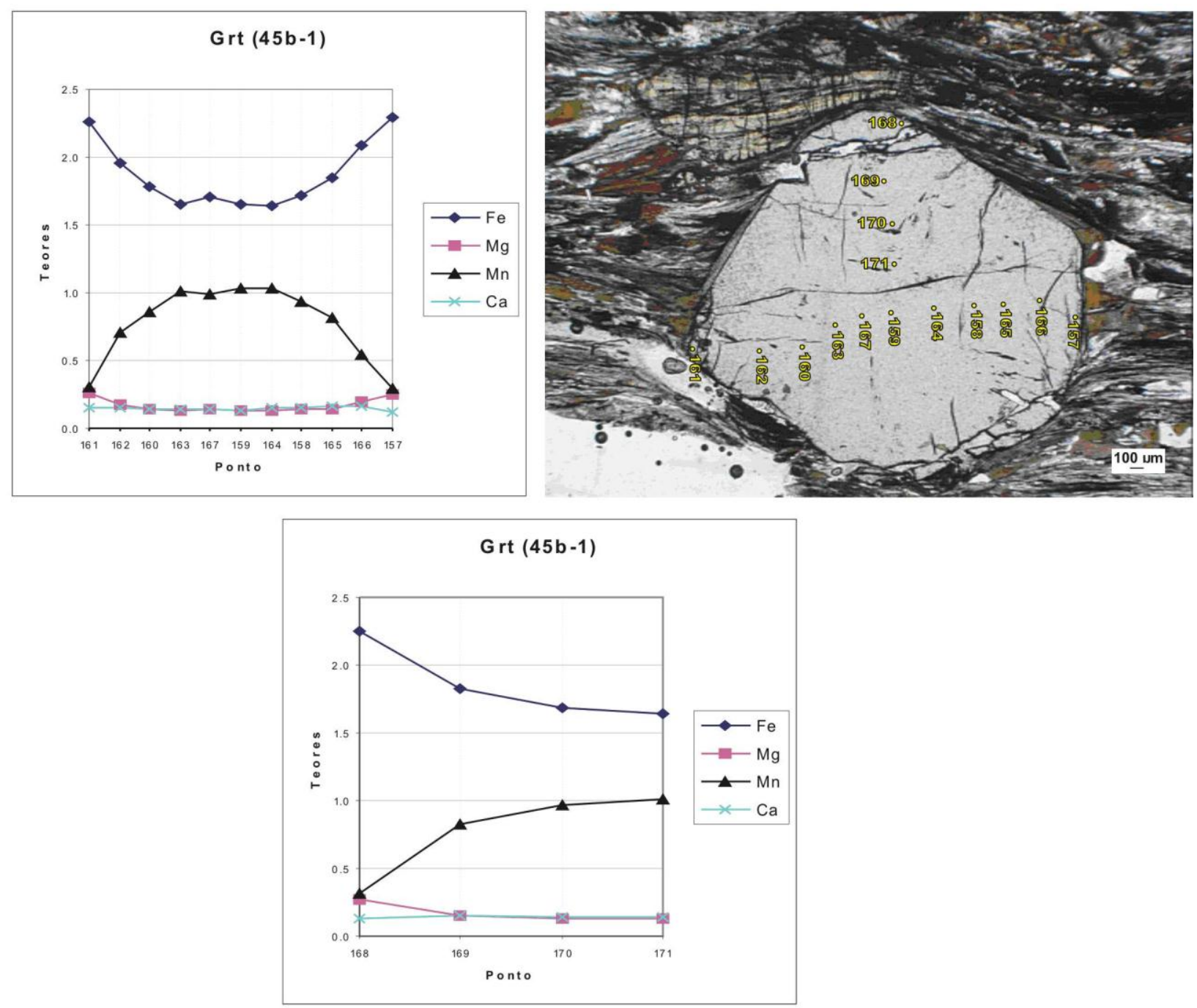

Figura 14. Perfil composicional em granada da amostra $45 \mathrm{~b}$ e foto com os pontos nos quais foram feitas as análises.
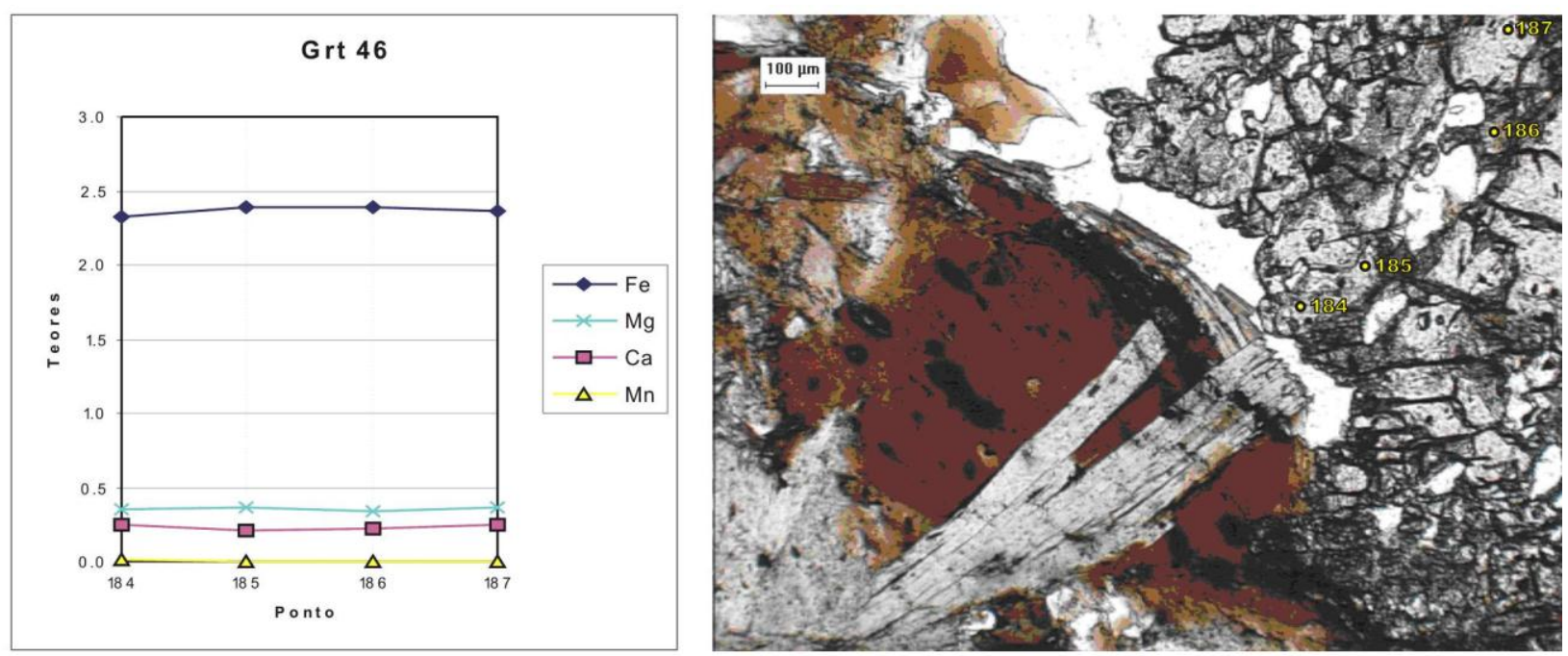

Figura 15. Gráfico dos pontos analisados em granada da amostra 46 e foto com os pontos nos quais foram feitas as análises. 
Os grãos de biotita analisados exibem composições químicas semelhantes, com pequenas diferenças nos conteúdos de $\mathrm{Fe}, \mathrm{Mg}$ e Ti. $\mathrm{Na}$ amostra 45b apresenta conteúdos de $\mathrm{FeO}$ entre 20,8 e 24,62\%; MgO entre 8,9 e 10,6\% e $\mathrm{TiO}_{2}$ de 1,2 a 1,6\%, encontrando-se um ponto com conteúdo de $\mathrm{TiO}_{2}$ de 0,87\%, provavelmente indicativo de maior influência de retrometamorfismo e/ou cloritização incipiente. Nesta lâmina, a biotita situada nas proximidades da granada apresenta os maiores conteúdos de Ti, e uma sucessão de quatro pontos indica um aumento de Ti no núcleo e redução na borda do mineral, indicando claramente a preservação de composições formadas em temperaturas iniciais mais altas. No caso da seção 46, a biotita apresenta conteúdos de $\mathrm{FeO}$ de 21,2 a 22,1\%; $\mathrm{MgO}$ de 7,9 a 8,3\% e $\mathrm{TiO}_{2}$ de 1,8 a 2,3\%. Neste caso, o $\mathrm{Ti}$ comporta-se semelhantemente ao observado na biotita da lâmina $45 \mathrm{~b}$, reduzindo seus teores do núcleo para a borda (Figura 16).

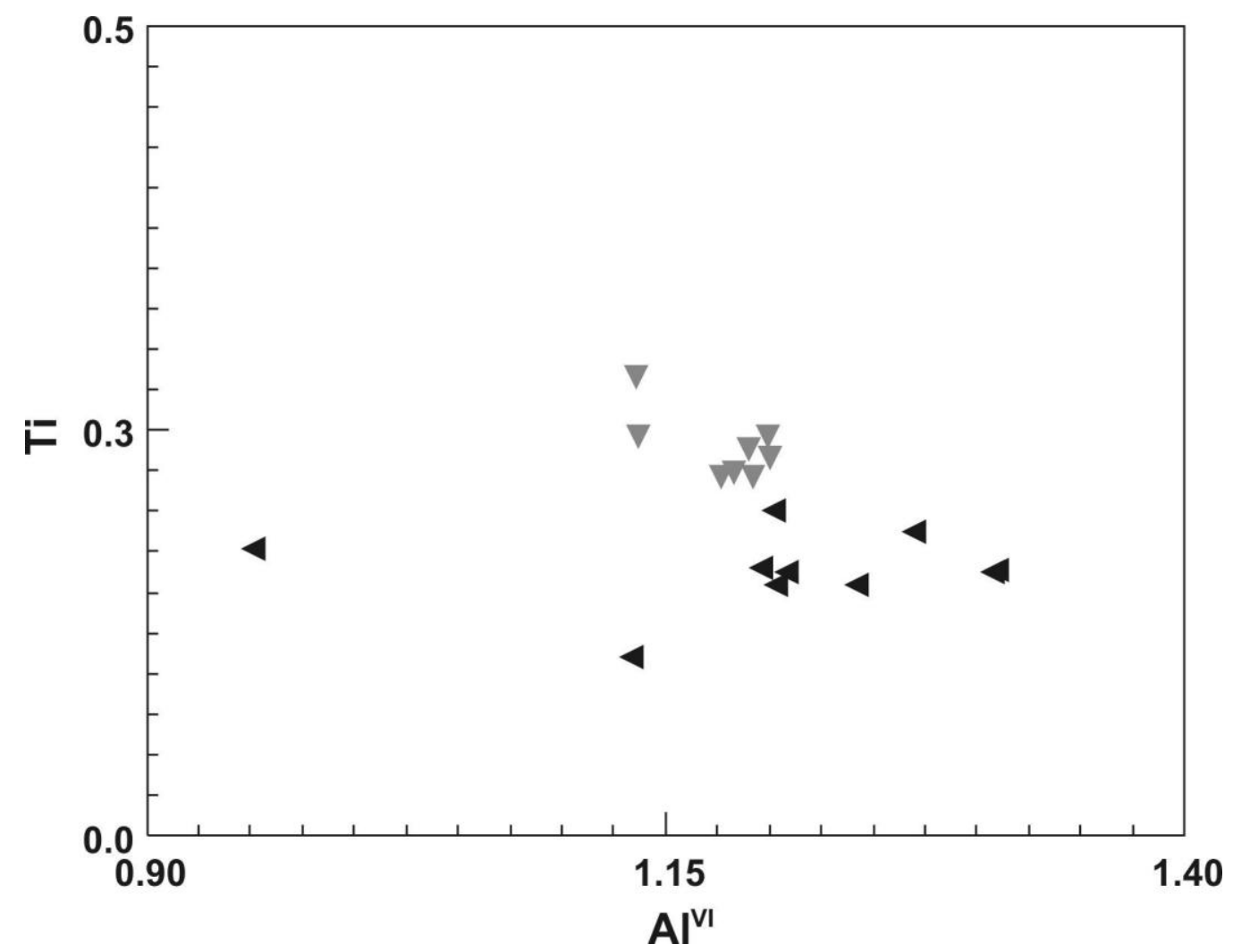

Figura 16. Diagrama representativo de variação dos teores de $\mathrm{Ti}$ e $\mathrm{Al}^{\mathrm{VI}}$ na biotita das amostras 45b (triângulos deitados) e 46 (triângulos invertidos).

A muscovita das amostras 45b e 46 apresenta diferenças nos conteúdos de FeO e $\mathrm{MgO}$. Na lâmina 45b o FeO apresenta valores do núcleo para a borda entre 0,7 e 0,8\% e conteúdos de $\mathrm{MgO}$ que oscilam entre 0,4 e 0,5\%. Na seção 46, o FeO oscila entre 1,9 e 2,5\%, havendo uma única análise com 3,5\%. O MgO exibe valores variando de 0,9 a 1,4\%, sugerindo temperaturas um pouco menores durante a cristalização e/ou 
recristalização das partes mais externas dos cristais de muscovita (Figura 17).
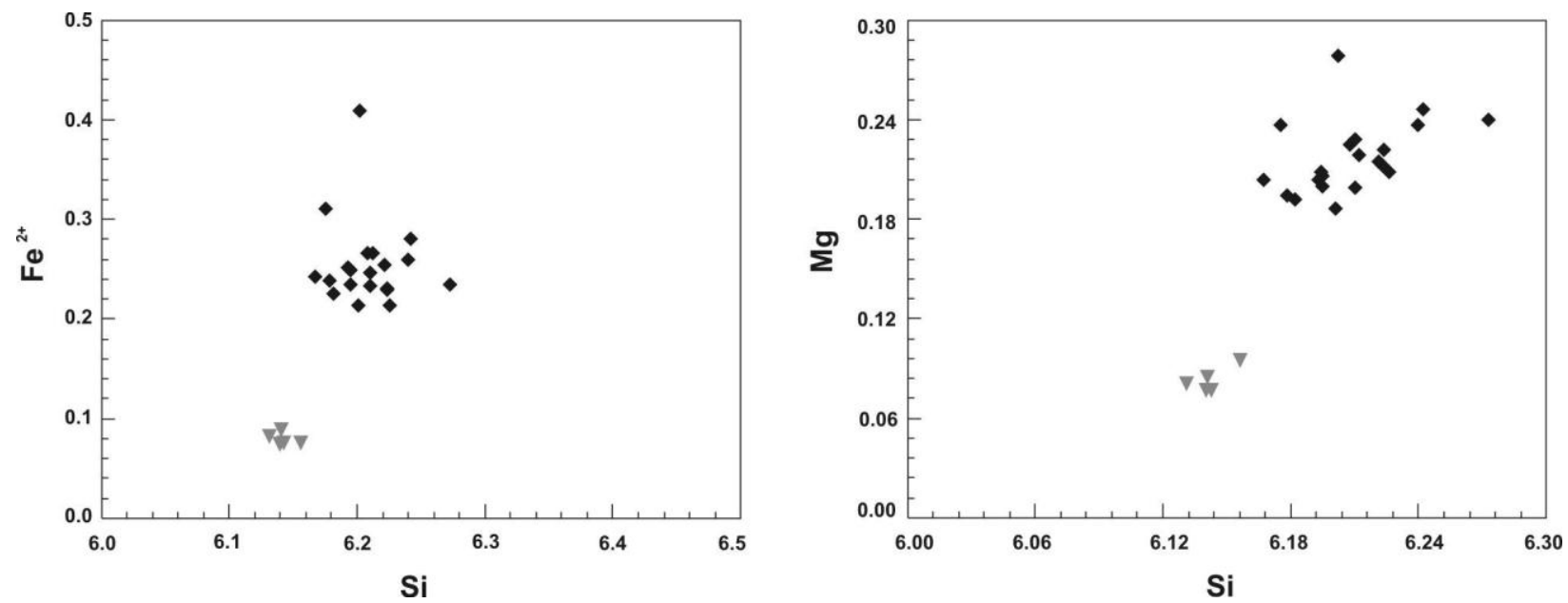

Figura 17. Diagramas representativos dos conteúdos de $\mathrm{Fe}^{2+}$ e celadonita $(\mathrm{Mg})$ na muscovita das amostras 45b (triângulos) e 46 (losangos).

A clorita que substitui completamente a biotita, presente em ambas as seções, apresenta composições homogêneas na distribuição de cada um de seus compostos, mas com quantidades diferentes em cada uma das seções analisadas. Na seção 45b, o FeO varia entre 24,6 e 25,2\% e o MgO oscila entre 13,3 e 13,7\%. Na seção 46, o FeO apresenta conteúdos que variam entre 29,3 e 30,1\% e de MgO entre 10,9 e $11,9 \%$.

A estaurolita da lâmina 45b, a qual constitui, em sua maioria, porfiroblastos xenoblásticos, tem composição homogênea, com conteúdos de $\mathrm{Al}_{2} \mathrm{O}_{3}$ que variam entre 53,9 e 54,8\%; de FeO entre 12,1 e 12,9\% e de $\mathrm{MgO}$ entre 1,3 a 1,4\%.

O plagioclásio da lâmina 46 encontra-se como cristais xenoblásticos disseminados. Sua composição é de andesina, com teor de anortita variando entre $A n_{35,5}$ e $A n_{37,7}$ (Figura 18). 


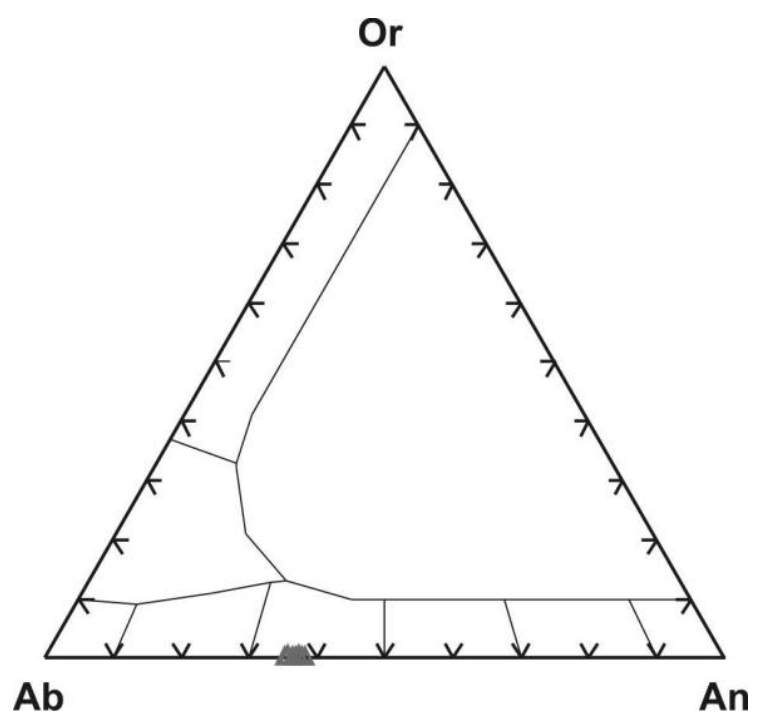

Figura 18. Diagrama de classificação do plagioclásio da amostra 46 dos Xistos de Ancón em termos de ortoclásio (Or), albita (Ab) e anortita (An).

\subsection{Anfibolitos, Migmatitos e Granulitos de El Retiro}

Deste conjunto de rochas foram realizadas análises em uma amostra de migmatito, uma de sericita xisto com cloritóide e em duas de rochas da fácies granulito, ambas granofels com ortopiroxênio.

A seção 53 corresponde ao melanossoma de um migmatito e nela foram feitas análises de granada, biotita, muscovita e plagioclásio. A granada nesta seção apresenta-se porfiroblástica, estirada e muito fraturada. Sua composição química é homogênea, o que é típico de rochas formadas em temperaturas altas, onde a difusão intracristalina torna-se mais efetiva, facilitando a homogeneização química. Pequenas variações entre almandina $(77,43-81,24 \%)$, piropo $(8,98-13,34 \%)$, espessartita $(4,52-$ $7,70 \%)$ e grossulária $(1,75-2,68 \%)$ são, deste caso, devidas ao re- e retrometamorfismo, mas sua composição é, em essência, almandínica (Figura 19).

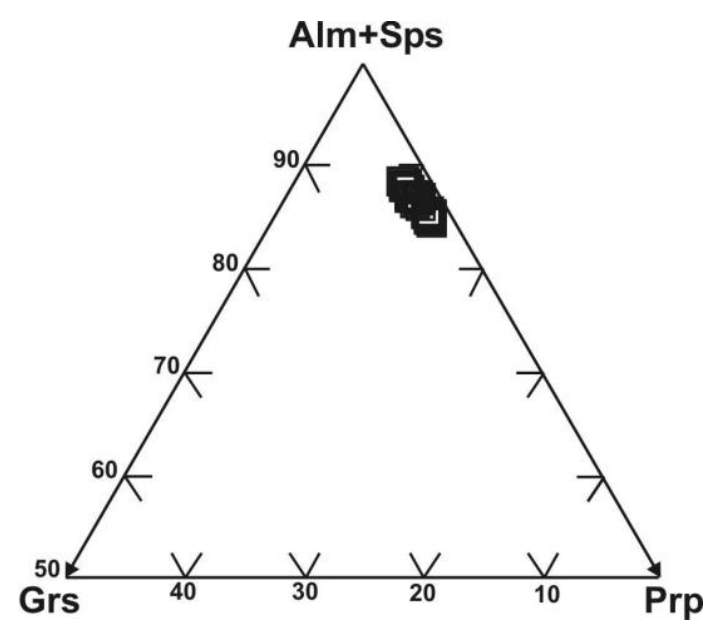

Figura 19. Composições das granadas em termos de almandina + espessartita (Alm+Sps), piropo (Prp) e grossulária (Grs) na unidade de Migmatitos e rochas em fácies Granulito de El Retiro. 
Zonamentos suaves podem ser observados, com pequenos enriquecimentos de Fe nas bordas e Mg no núcleo, indicando redução de temperatura do núcleo para a borda. O Ca e o Mn apresentam um comportamento muito homogêneo, definindo um perfil com seção praticamente plana, com pequenas inflexões (Figuras 20a, 20b e 20c). Este padrão, especialmente o do $\mathrm{Ca}$, é devido ao maior raio iônico do elemento, o que dificulta sua mobilidade química dentro do cristal em temperaturas relativamente baixas, onde a cinética das reações torna-se efetivamente mais lenta.

A biotita é subidioblástica e xenoblástica e faz parte da foliação ou ocorre inclusa na granada. Quimicamente, apresentam-se conteúdos de FeO 19,5-22,5\%, MgO 6,17,9\% e $\mathrm{TiO}_{2}$ 2,5-4,3\%, mas apresentam uma distribuição aleatória destes óxidos, impossibilitando correlações entre a cristalização e as variações da temperatura do metamorfismo. Isto, entretanto, é também típico de minerais parcialmente afetados por eventos re- ou retrometamórficos, notadamente quando sob deformação.

A muscovita também se orienta segundo a foliação e ocorre como inclusão em granada. Mostram-se conteúdos de $\mathrm{Al}_{2} \mathrm{O}_{3}$ 34,4-35,2\%, $\mathrm{FeO}$ 1,1-1,6\% e $\mathrm{MgO}$ 0,5-0,7\%. Os conteúdos de $\mathrm{MgO}$ e $\mathrm{FeO}$, tal qual no caso da biotita, não apresentam uma distribuição muito regular, que permita a definição de vetores de enriquecimento ou de empobrecimento nas bordas ou nos núcleos dos cristais.

O plagioclásio ocorre esporadicamente na seção, em contato com muscovita. Tem hábito xenoblástico e apresenta algumas exsoluções de quartzo. O cristal analisado apresenta uma composição muito homogênea, correspondendo a albita, com conteúdos de anortita de $A n_{2,2}-A n_{3,0}$, com ortoclásio variando entre 0,3 e $0,5 \%$, o que indica recristalização retrometamórfica e/ou saussuritização.

A seção $32 \mathrm{~d}$, corresponde a um sericita xisto com cloritóide, rocha esta em claro desequilíbrio metamórfico com os migmatitos ou granulitos.

A granada apresenta-se como fragmentos disseminados e exibe composição homogênea, em essência almandínica, com conteúdos importantes de piropo e quantidades menores de grossulária e espessartita. As variações dos membros-finais pode ser expressa: almandina (70,56-71,91\%), piropo (22,89-24,19\%), grossulária $(2,90-3,29 \%)$ e espessartita $(1,90-2,19 \%)$ e é apresentada na Figura 21 . Esta composição permite a inferência de ser esta granada relíquia de um evento metamórfico de mais alto grau, pois é incompatível com a fácies dos xistos verdes, que pode, assim, representar um reequilíbrio retrometamórfico. 

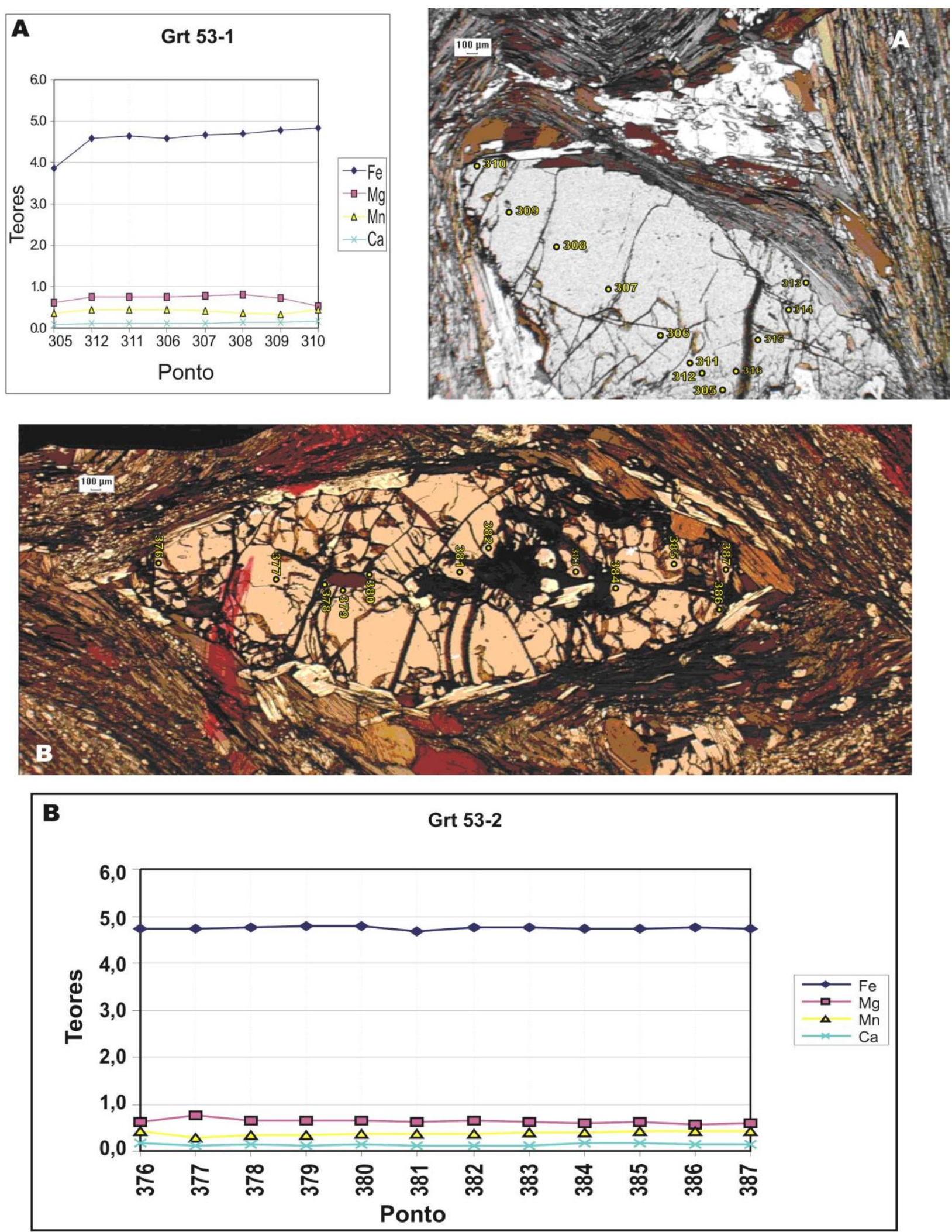

Figura 20 (A e B). Perfis composicionais em granada da amostra 53 e fotos com os pontos nos quais foram feitas as análises. 

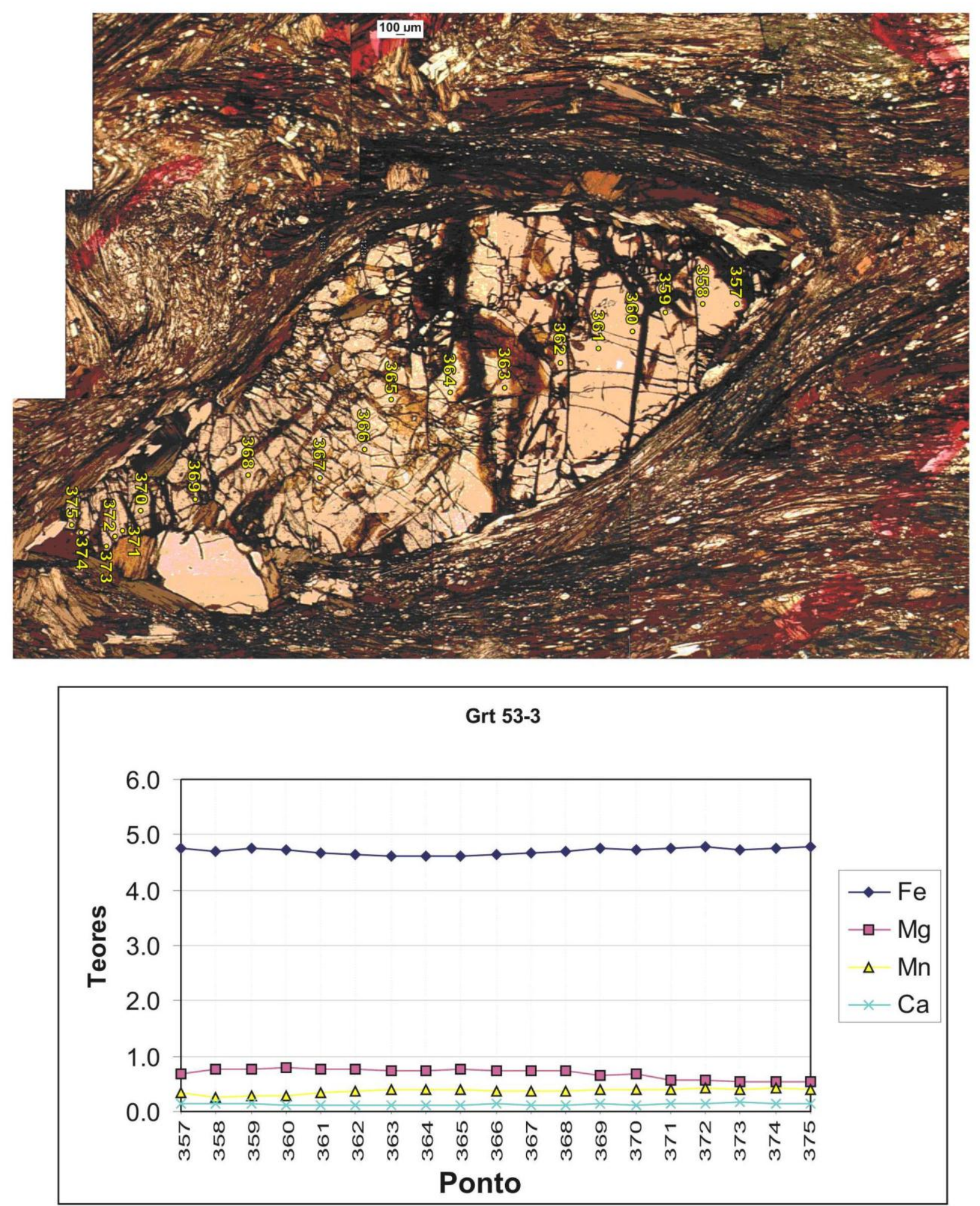

Figura 20 (C). Perfil composicional em granada da amostra 53 e foto com os pontos nos quais foram feitas as análises 


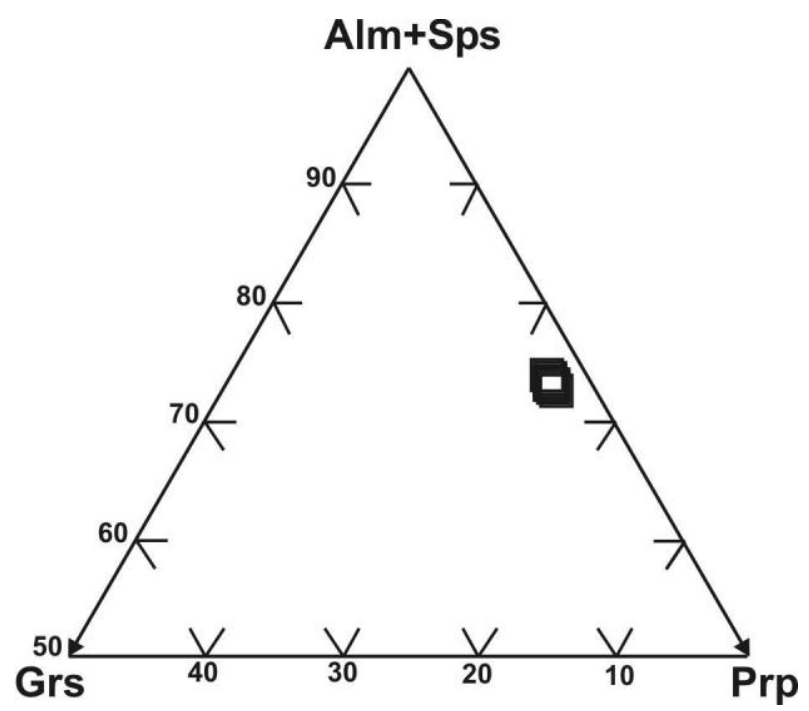

Figura 21. Composições da granada em termos de almandina + espessartita (Alm+Sps), piropo (Prp) e grossulária (Grs) em um sericita xisto da unidade de Migmatitos e rochas em fácies Granulito de El Retiro.

A clorita, encontrada como substituição de biotita apresenta conteúdos de $\mathrm{FeO}$ que variam entre 25,69-26,64\%, $\mathrm{Al}_{2} \mathrm{O}_{3} 23,01-23,45 \%$ e $\mathrm{MgO} 12,30-13,29 \%$.

O cloritóide constitui porfiroblastos subidioblásticos com bordas substituídas por sericita. Quimicamente, apresenta conteúdos de $\mathrm{Al}_{2} \mathrm{O}_{3}$ entre 40,34-40,94\%, $\mathrm{FeO} 22,89$ 23,45\% e MgO 2,48-3,00\%.

As seções 854A e ER2 correspondem a rochas da fácies granulito, nas quais foram feitas análises em plagioclásio e piroxênio. Também foram analisados biotita na seção 854A e anfibólio na ER2.

O ortopiroxênio em ambas as amostras constituem núcleos relativamente preservados pela substituição retrometamórfica nas bordas por anfibólio, que chegam a formar textura kelifítica quando a substituição é total. Desta forma, não houve, em nenhuma situação, a preservação da borda dos minerais, obliterando parcialmente as composições químicas do final do metamorfismo na fácies granulito. Quimicamente o ortopiroxênio é enstatita, com a seguinte composição: enstatita (53,76-56,16\%), ferrossilita $(41,47-45,09 \%)$ e wollastonita $(0,97-3,07 \%)$ na seção ER2 e enstatita $(55,78-57,05 \%)$, ferrossilita $(42,56-43,95 \%)$ e wollastonita $(0,27-0,38 \%)$ na seção $854 \mathrm{~A}$. Estas variações podem ser observadas na Figura 22. 


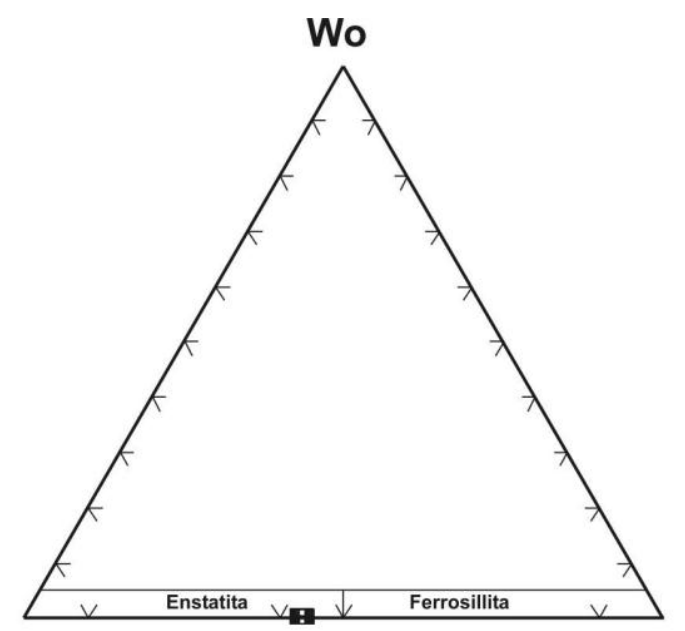

En

Fs

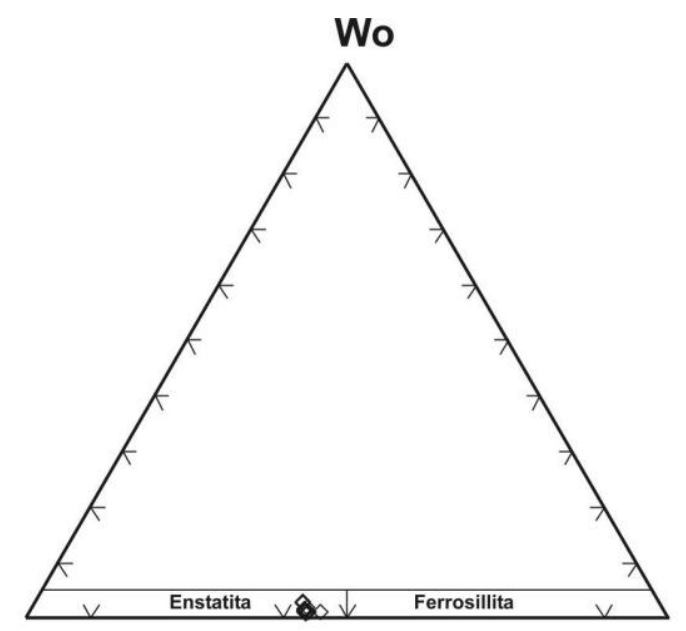

En
Fs

Figura 22. Composição do piroxênio em termos de wollastonita (Wo), enstatita (En) e ferrossilita (Fs) em duas amostras da unidade de Migmatitos e rochas em fácies Granulito de El Retiro. À esquerda dados da amostra 854-A e à direita amostra ER-2.

O plagioclásio, parte integrante da textura granoblástica das rochas e das inclusões do ortopiroxênio, apresenta-se subidioblástico e xenoblástico. A composição química nas duas lâminas é distinta (Figura 23) e confirma o zonamento inverso observado na petrografia.

Na lâmina ER2, o plagioclásio corresponde à bytownita, com diminuição no teor da molécula de anortita do núcleo para a borda, sendo a borda mais enriquecida na molécula de albita. Os conteúdos de anortita variam segundo $A n_{69,4}$ a $A n_{89,4}$, havendo um ponto analítico que corresponde à labradorita $\left(A n_{39,2}\right)$ e um de andesina. $O$ zonamento sugere cristalização em contínua redução de temperatura do núcleo para a borda. O plagioclásio da lâmina 854A, apresenta conteúdos de anortita mais homogêneos, mas igualmente com zonamento inverso, indicando uma redução da temperatura do núcleo para a borda. As variações da molécula de anortita podem ser expressas: $A n_{38,6}-A n_{42,2}$. 


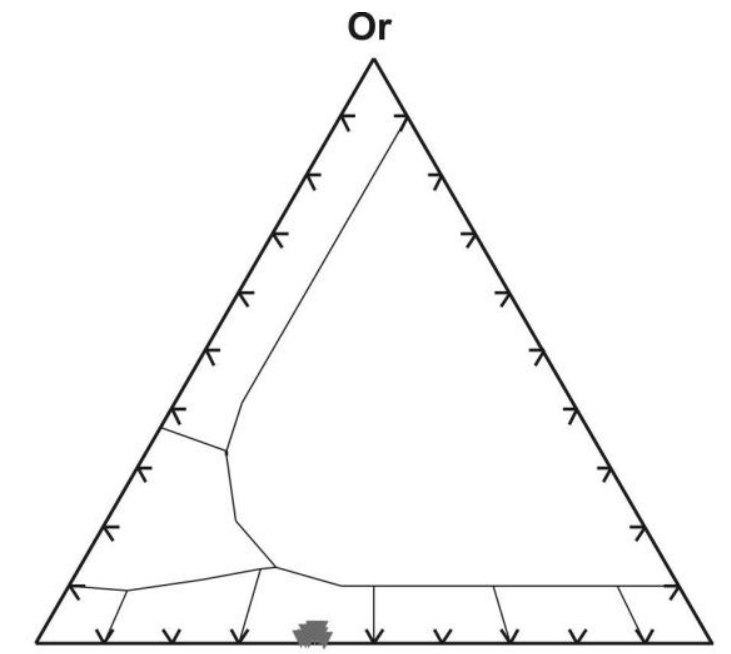

Ab

Figura 23. Diagrama de classificação do plagioclásio em duas amostras da unidade de Migmatitos e rochas em fácies Granulito de El Retiro em termos de ortoclásio (Or), albita (Ab) e anortita (An). À esquerda dados da amostra 854-A e à direita amostra ER-2

$\mathrm{Na}$ lâmina ER2 foram feitas algumas análises em uma borda kelifítica de anfibólio em um ortopiroxênio, o qual, segundo a classificação de Leake et al. (1997), tem composição de cummingtonita (Figura 24), confirmando a petrografia e indicando cristalização em condições retrometamórficas.

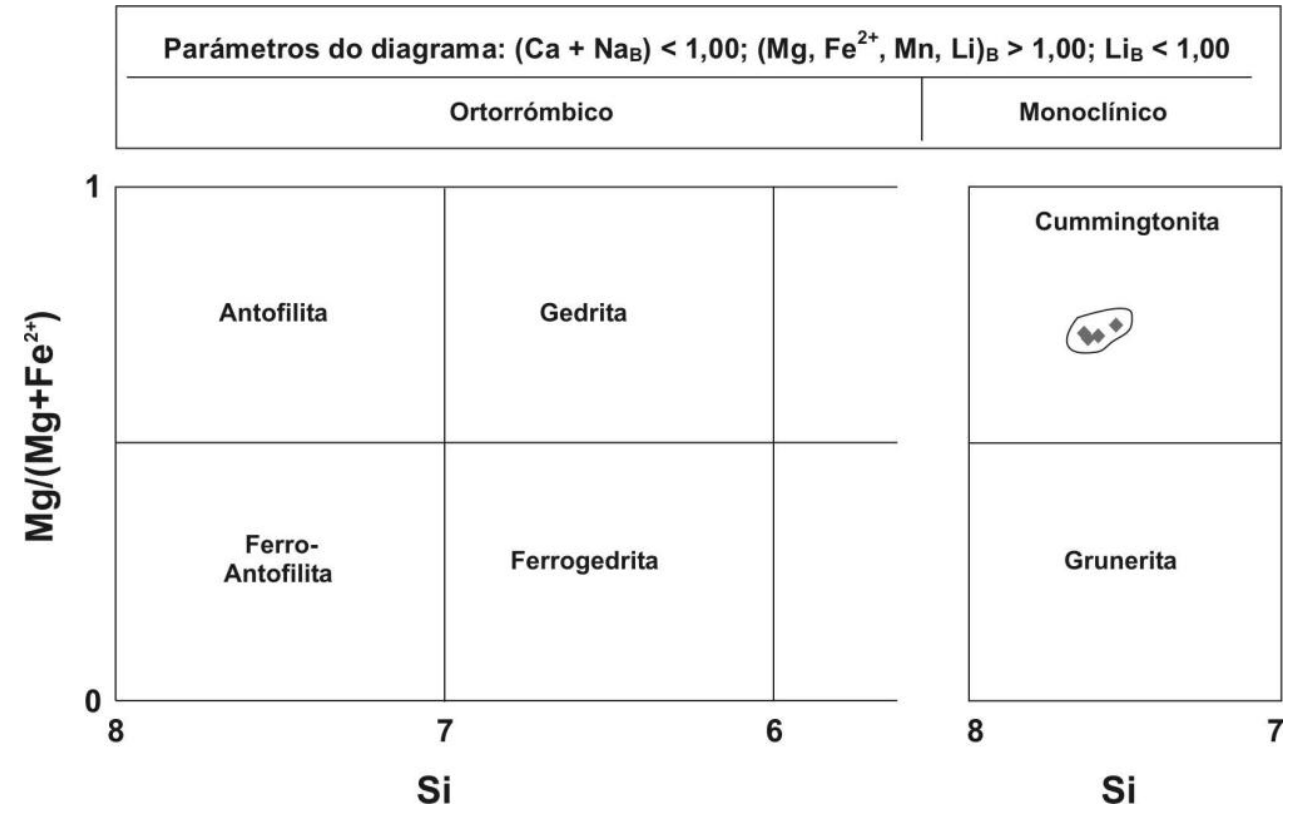

Figura 24. Classificação química dos anfibólios presentes nas bordas do ortopiroxênio na amostra ER-2. O diagrama corresponde à classificação dos anfibólios de Fe-Mg-Mn-Li (Leake et al., 1997).

Poucas análises foram feitas em biotita mas, mesmo assim, os resultados indicam a existência de um aumento de Ti no núcleo com relação as bordas, sugerindo temperaturas de cristalização mais altas no núcleo do que nas bordas. 


\section{GEOTERMOBAROMETRIA: APLICAÇÃO, CONCEITOS E CALIBRAÇÕES}

Geotermobarometria é o nome dado aos cálculos da pressão e da temperatura de formação dos minerais, obtidos a partir de uma constante de equilíbrio (Spear, 1989). Esta técnica pode ser aplicada a paragêneses ígneas, mas seu uso é mais generalizado no estudo das rochas metamórficas. As calibrações dos geotermômetros e geobarômetros são feitas de dois modos:

a) Experimentais: são aquelas que dependem das medidas em laboratório da constante de equilíbrio de uma determinada reação em função da temperatura e a pressão em experimentos, sob condições químicas controladas.

b) Empíricas: são as que dependem de medidas da constante de equilíbrio em assembleias que ocorrem naturalmente, das quais a temperatura e a pressão do equilíbrio são inferidas a partir de outros, como as paragêneses minerais ou dados de isótopos estáveis (Spear, 1989).

A suposição fundamental na aplicação de alguma relação de equilíbrio é que as fases envolvidas estejam em equilíbrio e esta, em geral, é a condição de confirmação mais difícil e, consequentemente, resulta na maior fonte de erros na aplicação dos geotermobarômetros, uma vez que é sempre possível provar-se que as fases não estão em equilíbrio, mas é impossível provar-se que uma assembleia está em equilíbrio termodinâmico (Spear, 1989).

O fundamento da geotermobarometria baseia-se no fato de que a constante de equilíbrio (Equação 1) de uma determinada reação química pode ser determinada pela medida da composição química dos minerais coexistentes, aplicada a modelos de atividade, desde que as propriedades calorimétricas das substâncias sejam conhecidas. Uma constante de equilíbrio simples definiria uma linha em um diagrama P-T e, como os equilíbrios de end-members ou de diferentes minerais em paragênese apresentam-se como reações com diferentes taxas de inclinação nos diagramas P-T, a intersecção de dois equilíbrios pode ser usada na estimativa das condições de pressão e temperatura do equilíbrio das reações e, portanto, de formação e/ou reequilíbrio dos minerais das rochas.

Como geotermômetros são utilizados os equilíbrios pouco dependentes da pressão e como geobarômetros os equilíbrios que são relativamente insensíveis à temperatura.

Uma avaliação dos equilíbrios que podem ser utilizáveis para geotermometria e 
geobarometria pode ser feita examinando-se a dependência da pressão e da temperatura da constante equilíbrio (Equações 2 e 3).

$0=\Delta H\left(T_{R}, P_{R}\right)+\int \Delta C_{P} d T-T\left(\Delta S\left(T_{R}, P_{R}\right)\right)+\int\left(\left(\Delta C_{P} / T\right) d T\right)+\Delta V_{S}(P-1)+R T \ln K_{\text {eq }}$

onde:

$\Delta H=$ Entalpia, $T_{R}=$ Temperatura de referência, $P_{R}=$ Pressão de referência, $\Delta C_{P}=$ Capacidade de troca de calor da reação, $T=$ Temperatura, $\Delta S=$ Entropia, $\Delta V_{S}=$ Mudança de volume dos sólidos, $P=$ Pressão, $R=$ Constante dos gases, $K_{e q}=$ Constante de equilíbrio

$$
\begin{aligned}
& 0=\left[R \operatorname{lnK} K_{e q}-\left(\Delta S\left(T_{R}, P_{R}\right)+\int\left(\Delta C_{P} / T\right) d T\right)\right] d T+\Delta V_{s} d P+R T d \ln K_{e q}
\end{aligned}
$$

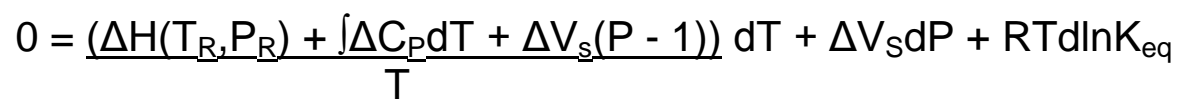

Iniciando-se com a derivada total da lei de ação de massa obtem-se:

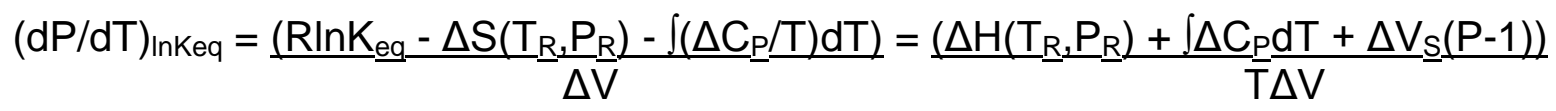

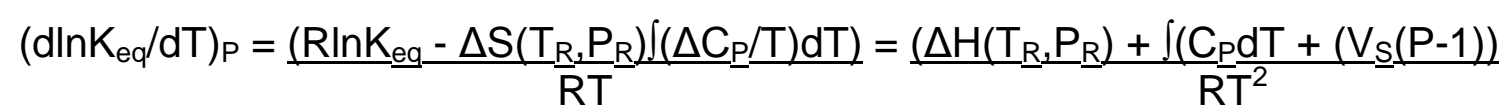

$$
\begin{aligned}
& (\mathrm{dlnKeq} / \mathrm{dP})_{\mathrm{T}}=\underline{\Delta \mathrm{V}} \underline{\mathrm{ST}}
\end{aligned}
$$

Da equação 4 , a inclinação de uma isopleta de $\mathrm{K}_{\text {eq }}$ resulta numa função da entropia e no volume de uma reação. Geralmente um equilíbrio com grande $\Delta S$ é relacionado a fortes inclinações de RInKeq e um equilíbrio com grande $\Delta \mathrm{V}$ tem inclinações suaves. A dependência da pressão e da temperatura da constante de equilíbrio é tão importante como a inclinação da curva P-T para as determinações precisas da pressão e da temperatura. Como se pode deduzir das equações 5 e 6 , um grande $\Delta \mathrm{H}$ é necessário para uma alta dependência da temperatura e um grande $\Delta \mathrm{V}$ é exigido para uma forte dependência da pressão, como pode ser visto na figura 25 (Figura 5). 


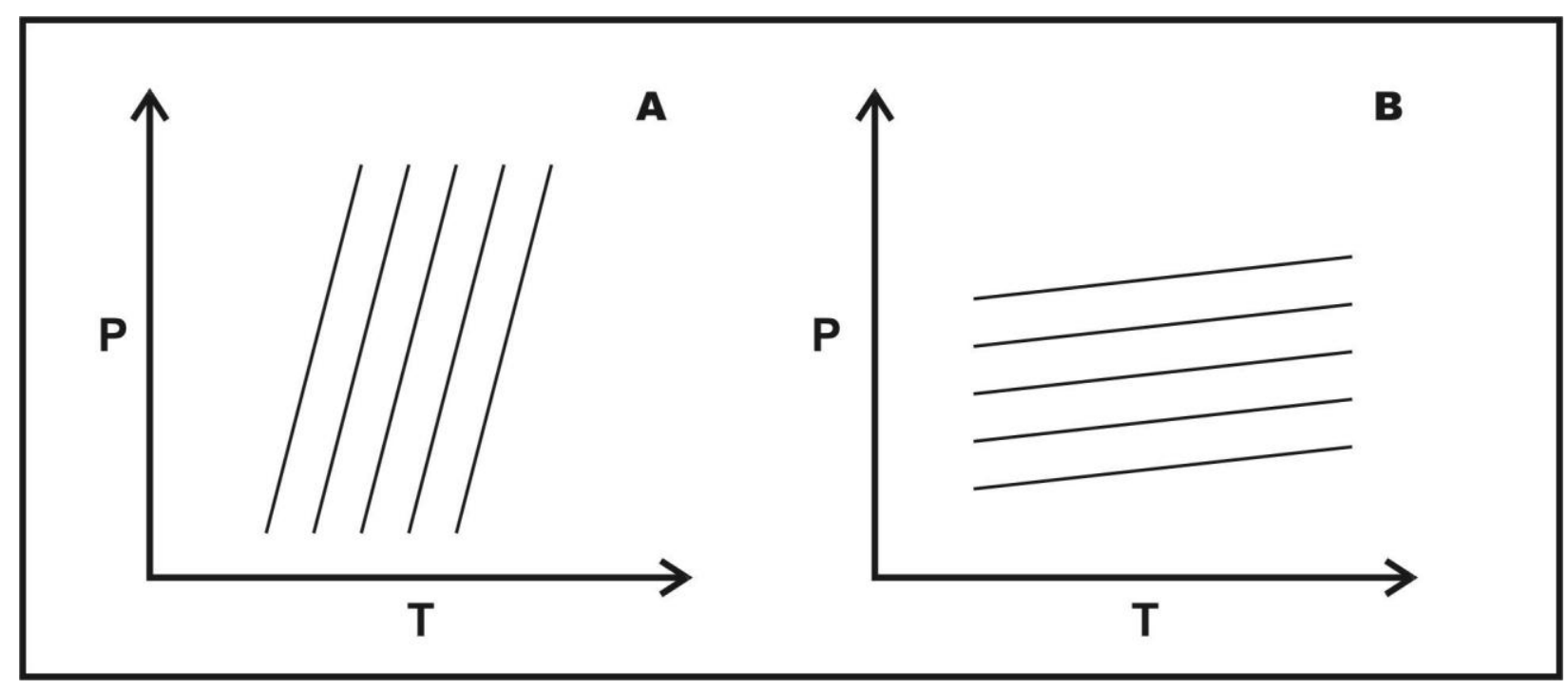

Figura 25. Diagramas esquemáticos P-T mostrando equilíbrios com inclinações P-T representativas de reações utilizáveis como geotermômetros $(A)$ e geobarômetros $(B)$. Spear, 1989.

Um número significativo de equilíbrios de trocas químicas de granada com biotita, anfibólio, cordierita, cloritóide, estaurolita assim como cloritóide-clorita, cloritóide-estaurolita e cloritóide-biotita, podem ser usados como geotermômetros em termos de distribuição ideal de $\mathrm{Fe}$ e $\mathrm{Mg}$ entre os minerais envolvidos e podem ser aplicados a paragêneses metamórficas sem correções composicionais com uma exatidão de 3-8\% (Perchuk, 1991).

Segundo Spear (1989; 1993), as reações usadas como geotermômetros são as de troca catiônica (exchange reactions) e para a geotermometria com base em solvus e como geobarômetros são usadas reações de transferência de rede (net transfer).

As reações de troca catiônica representam um grande número de geotermômetros, que envolvem especialmente a troca de Fe e Mg entre silicatos que coexistem. As reações de troca geralmente apresentam um pequeno $\Delta \mathrm{V}$ com um moderado $\Delta \mathrm{S}$ e $\Delta \mathrm{H}$ de forma que a isopleta da $\mathrm{K}_{\text {eq }}$ tem uma inclinação relativamente forte. A constante de equilíbrio para as reações de troca catiônica geralmente pode ser simplificada como uma relação de troca catiônica em uma fase dividida pela mesma relação na segunda fase (Spear, 1989). Esta formulação é definida como o coeficiente de distribuição $\left(\mathrm{K}_{\mathrm{D}}\right)$. Assim, por exemplo, o coeficiente de distribuição para a troca de Fe e $\mathrm{Mg}$ entre as fases A e B é definida como $\mathrm{K}_{\mathrm{D}}=(\mathrm{Fe} / \mathrm{Mg}) \mathrm{A} /(\mathrm{Fe} / \mathrm{Mg}) \mathrm{B}$ (Spear, 1989).

No caso dos geotermômetros solvus, várias calibrações são baseadas na distribuição dos elementos através do solvus. Em muitos casos a frase "geotermometria solvus" é um nome equivocado porque o termo "solvus" restringe-se a 
fases isoestruturais e vários dos denominados "geotermômetros solvus" atualmente envolvem duas fases que não são isoestruturais, devendo, portanto, serem mais corretamente chamados geotermômetros de troca catiônica (Spear, 1989; 1993).

As reações de transferência de rede (net transfer equilibria) são excelentes geobarômetros, pois elas têm grandes variações de volume o que significa que são reações que causam produção e consumo das fases sendo, conseqüentemente, a constante de equilíbrio sensível às variações da pressão (Spear, 1989; 1993).

Neste trabalho foram usados os geotermobarômetros internamente consistentes apresentados no TWQ, além do granada-clorita (Dickenson \& Hewitt, 1986), estaurolita-granada (Perchuk, 1991), cloritóide-clorita (Vidal et al., 1999) em amostras que não foi possível a obtenção de resultados P-T mediante o uso programa TWQ

\subsection{Geotermobarômetros Internamente Consistentes}

Considerando que a termobarometria é fácil de entender, a aplicação pratica não é a causa das consideráveis incertezas nos dados termodinâmicos e os modelos de atividade (Spear, 1993). Vários autores (e.g. Berman, 1988, 1990; Powell \& Holland, 1985,1988), começaram com a utilização de um conjunto de termômetros e barômetros internamente consistentes como uma forma de obter estimações de pressão e temperatura mais coerentes. O conjunto de calibrações internamente consistentes utiliza os mesmos dados termodinâmicos e modelos de atividade para todas as fases ou foram calibrados usando o mesmo conjunto de dados empíricos (Spear, 1993). A consistência interna entre os conjuntos de calibrações da assegura o grau no qual uma amostra esta equilibrada. A consistência interna tem a tendência de eliminar, ou pelo menos identificar, calibrações com grandes erros sistemáticos porque tem a tendência a permanecer visíveis (Spear, 1993).

\subsection{Geotermômetro Granada(Grt)-Clorita(Chl)}

O geotermômetro empírico granada-clorita (Dickenson \& Hewitt, 1986) é baseado na partição $\mathrm{Fe}-\mathrm{Mg}$ entre ambos minerais em rochas da fácies xisto verde e anfibolito baixo, mas também é aplicável para minerais de rochas formadas em terrenos de alta pressão e baixa temperatura, onde a biotita usualmente não está presente. Além disso, o geotermômetro granada-clorita é muito útil na definição do segmento retrógrado das trajetórias P-T do metamorfismo, por utilizar reações que ocorrem com a exumação dos cinturões metamórficos (Dickenson \& Hewitt, 1986). 
A expressão polibárica e politérmica formulada para representar a partição entre granada e clorita, assim como o $\mathrm{K}_{\mathrm{D}}$ são:

$$
\mathbf{T}=\frac{51906+0.438 \mathrm{P}}{7.541-15 \mathrm{R} \ln \mathrm{K}_{\mathrm{D}}} \quad \mathrm{K}_{\mathrm{D}}=\frac{(\mathrm{Mg} / \mathrm{Fe})^{\mathrm{Grt}}}{(\mathrm{Mg} / \mathrm{Fe})^{\mathrm{Chl}}}
$$

\subsection{Geotermômetro Estaurolita(St)-Granada(Grt)}

O geotermômetro empírico estaurolita-granada foi calibrado inicialmente por Perchuk (1969), sendo posteriormente periodicamente revisado, em função da continua acumulação de análises minerais das fases coexistentes (Perchuk, 1991). A equação que define o geotermômetro, assim como o $K_{D}$ são:

$$
\mathbf{T}=\frac{2675+0.0075 P}{\ln K_{D}+2.799} \quad K_{D}=\left(\frac{X_{M g}}{1-X_{M g}}\right)^{S t} \times\left(\frac{1-X_{M g}}{X_{M g}}\right)^{G r t}
$$

\subsection{Geotermômetro Cloritóide(Cld)-Clorita(Chl)}

O geotermômetro empírico cloritóide-clorita baseia-se na troca Mg-Fe (Vidal et al.,1999) e pode ser aplicado somente se $\mathrm{XMg}_{\mathrm{Cld}}<0,2$ e $\mathrm{XMg}_{\mathrm{Cld}}>0,8$ a $700 \stackrel{\circ}{ } \mathrm{C}$, e $\mathrm{XMg}_{\mathrm{Cld}}<0,1$ e $\mathrm{XMg}_{\mathrm{Cld}}>0,9$ a $300^{\circ} \mathrm{C}$. A variação apresentada pelo $\mathrm{K}_{\mathrm{D}}$ com a pressão é tão discreta $\left(0,0008 \mathrm{kbar}\right.$ a $\left.750^{\circ} \mathrm{K}\right)$ que pode ser desprezada no cálculo da constante de equilíbrio. A equação que define o geotermômetro, assim como o $K_{D}$ são:

$$
\mathbf{T}=\frac{1977.7}{\ln K_{D}+0.971} \quad K_{D}=\frac{(F e / M g)^{C l d}}{(F e / M g)^{C h l}}
$$




\section{CÁLCULOS GEOTERMOBAROMÉTRICOS}

As análises químicas e as associações utilizadas neste capitulo mediante o uso do software TWQ, encontram-se nos anexos II e III.

Os cálculos geotermobarométricos foram feitos com as análises dos minerais das 9 seções, feitas em microssonda eletrônica, incluindo granada, anfibólio, plagioclásio, ortopiroxênio, biotita, muscovita, clorita, estaurolita e cloritóide, com ênfase na definição das variações e nos zonamentos químicos. Para os minerais que não se encontram em paragênese, foram analisados cristais de um mesmo domínio microestrutural, para buscar-se o máximo de possibilidade de equilíbrio termodinâmico e, consequentemente, uma maior coerência nos cálculos das condições de P e T que afetaram as diferentes rochas. Os símbolos de minerais usados neste capítulo estão na tabela 1.

Tabela 1. Símbolos de minerais usados neste capítulo segundo Kretz (1983) e Spear (1993).

\begin{tabular}{lllll}
\hline Ab albita & Cal calcita & Grs grossulária & Prg pargasita & St estaurolita \\
Alm almandina & Chl clorita & Grt* granada & Prp piropo & Tr tremolita \\
An anortita & Cld cloritóide & Ms muscovita & Qtz quartzo & Ts tschermakita \\
Ann annita & Dol dolomita & Phl flogopita & Sil sillimanita & \\
\hline
\end{tabular}

${ }^{*}$ Grupo de minerais

\subsection{Anfibólio Xistos de Caldas}

Das rochas desta unidade foram selecionadas amostras que continham a associação granada-anfibólio-plagioclásio em paragênese. Para todos minerais foram elaborados perfis composicionais que permitiram a detecção de zonamentos ou pequenas variações nas concentrações dos principais componentes químicos.

Os resultados de geotermobarometria das amostras deste conjunto, foram obtidos com o uso do TWQ 1.02, por ser este o único do conjunto de Berman (1988) que inclui as calibrações com anfibólio.

\subsubsection{Amostras 11c e 12c}

As duas amostras apresentam uma foliação milonítica definida pela orientação do anfibólio, com granada porfiroblástica rica em inclusões de anfibólio, plagioclásio, minerais opacos e epidoto-clinozoisita. Junto à borda dos cristais de granada ocorrem concentrações de plagioclásio sem geminação e sericita, esta última como produto da substituição do plagioclásio.

$\mathrm{Na}$ granada da seção 11c foram analisados três cristais, todos com perfis composicionais, e na seção $12 \mathrm{c}$ foi feito somente um perfil composicional de um 
porfiroblasto de granada.

Os cristais analisados de anfibólio incluem os inclusos na granada e os da foliação, principalmente, os situados em contado ou nas proximidades dos cristais de granada. O mesmo procedimento analítico foi aplicado para o plagioclásio.

Os resultados obtidos com os minerais da amostra 11c indicam equilíbrios termodinâmicos para os núcleos dos pares granada-anfibólio entre 7-8 kbar e 557$587^{\circ} \mathrm{C}$ (Figuras $26 \mathrm{~A}$ e B).

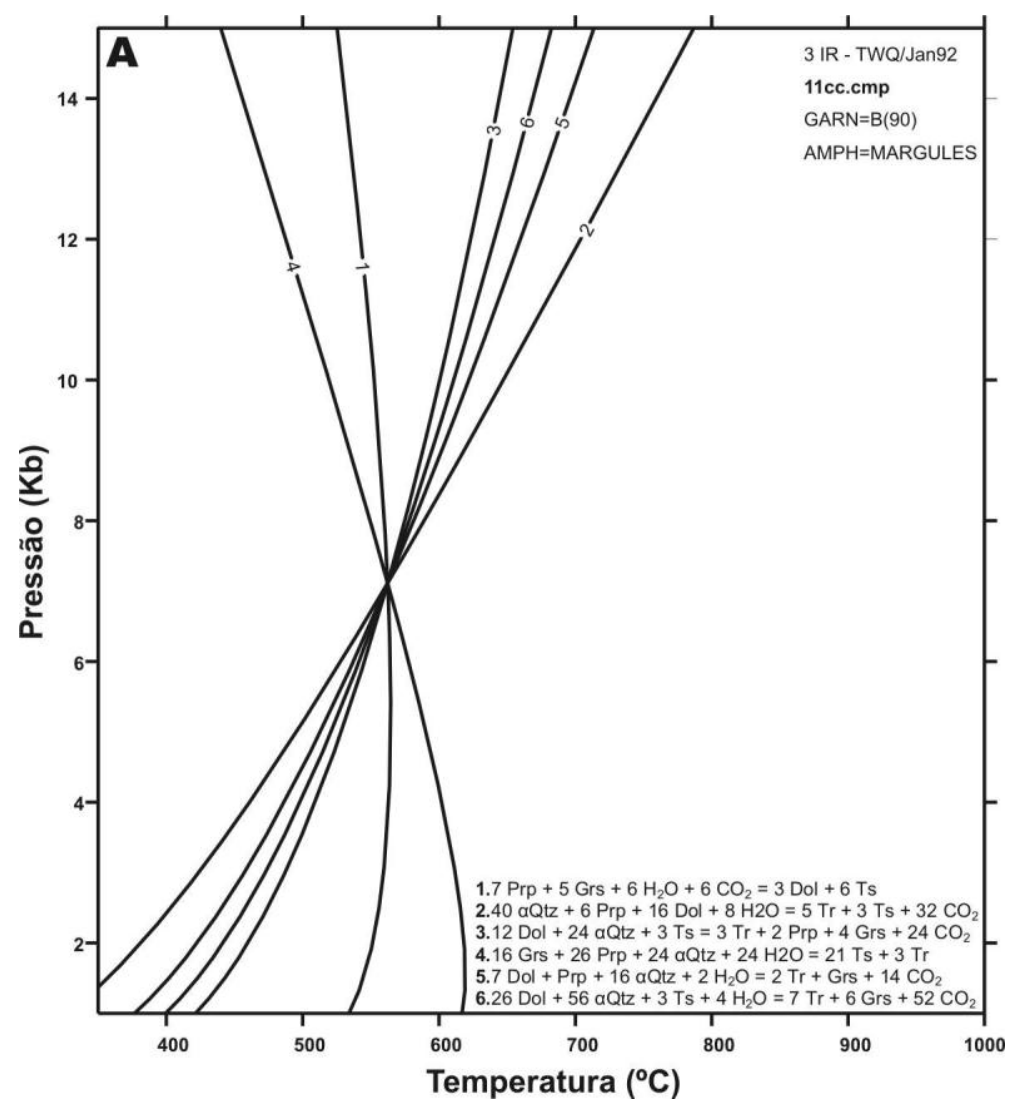

Figura 26 A. Diagramas P-T obtidos para a amostra 11c com as análises dos núcleos da granada e o anfibólio, com $\mathrm{XCO}_{2}=0,4$ e $\mathrm{XH}_{2} \mathrm{O}=0,6$. 


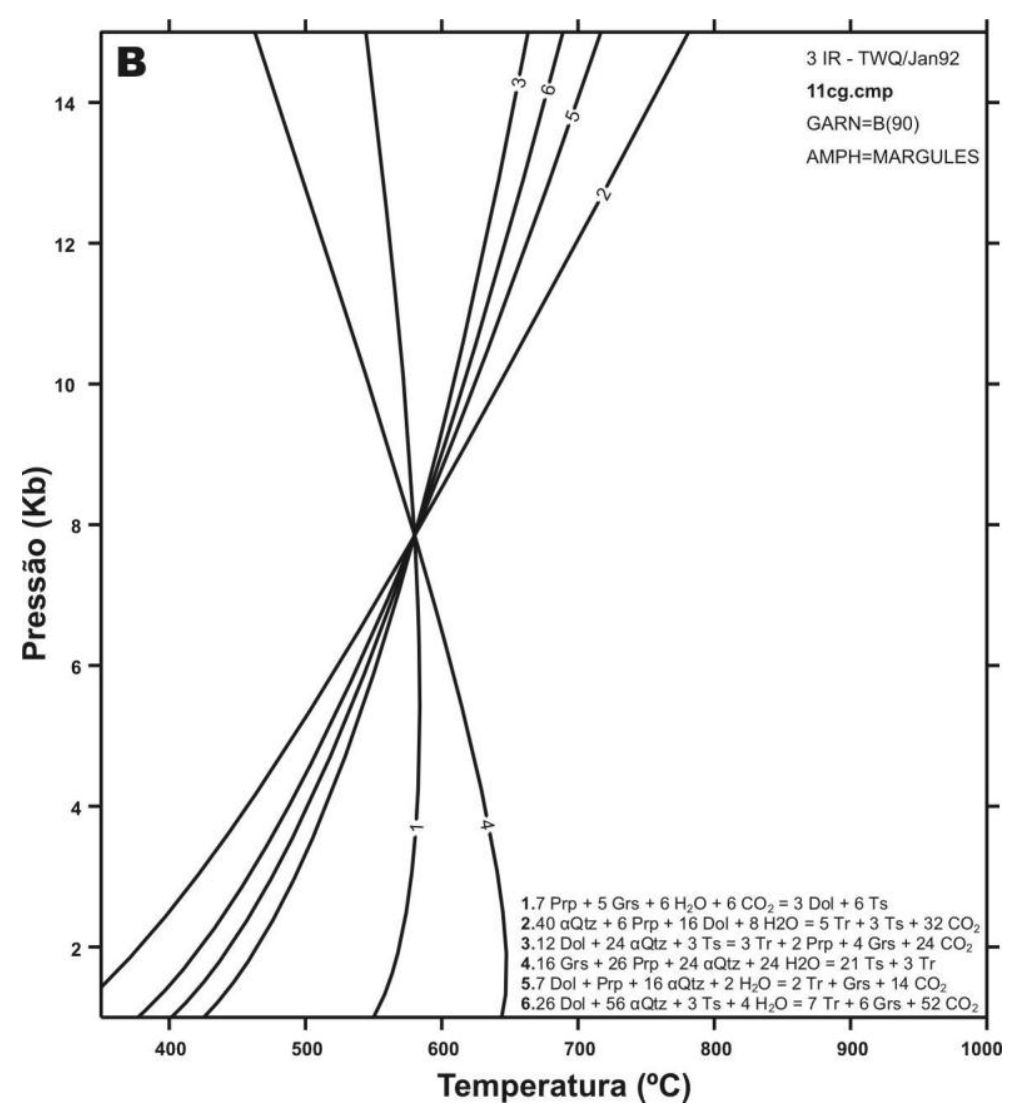

Figura 26 A. Diagramas P-T obtidos para a amostra 11c com as análises dos núcleos da granada e o anfibólio, com $\mathrm{XCO}_{2}=0,4$ e $\mathrm{XH}_{2} \mathrm{O}=0,6$.

Com as análises dos pontos intermediários dos cristais dos mesmos pares de minerais, os resultados variam entre $\sim 8,8-9,4$ kbar e 600-606 ำ (Figuras $27 \mathrm{~A} \mathrm{e} \mathrm{B)}$ ).

Já para as análises de bordas desta associação, os resultados oscilam entre 9,7-11,4 kbar e 608-633 ํ, situação esta que mostra um claro aumento das condições de pressão e temperatura dos núcleos para as bordas dos minerais analisados (Figuras 28 A e B), ou seja, encontra-se registrada parte da trajetória do metamorfismo progressivo. 

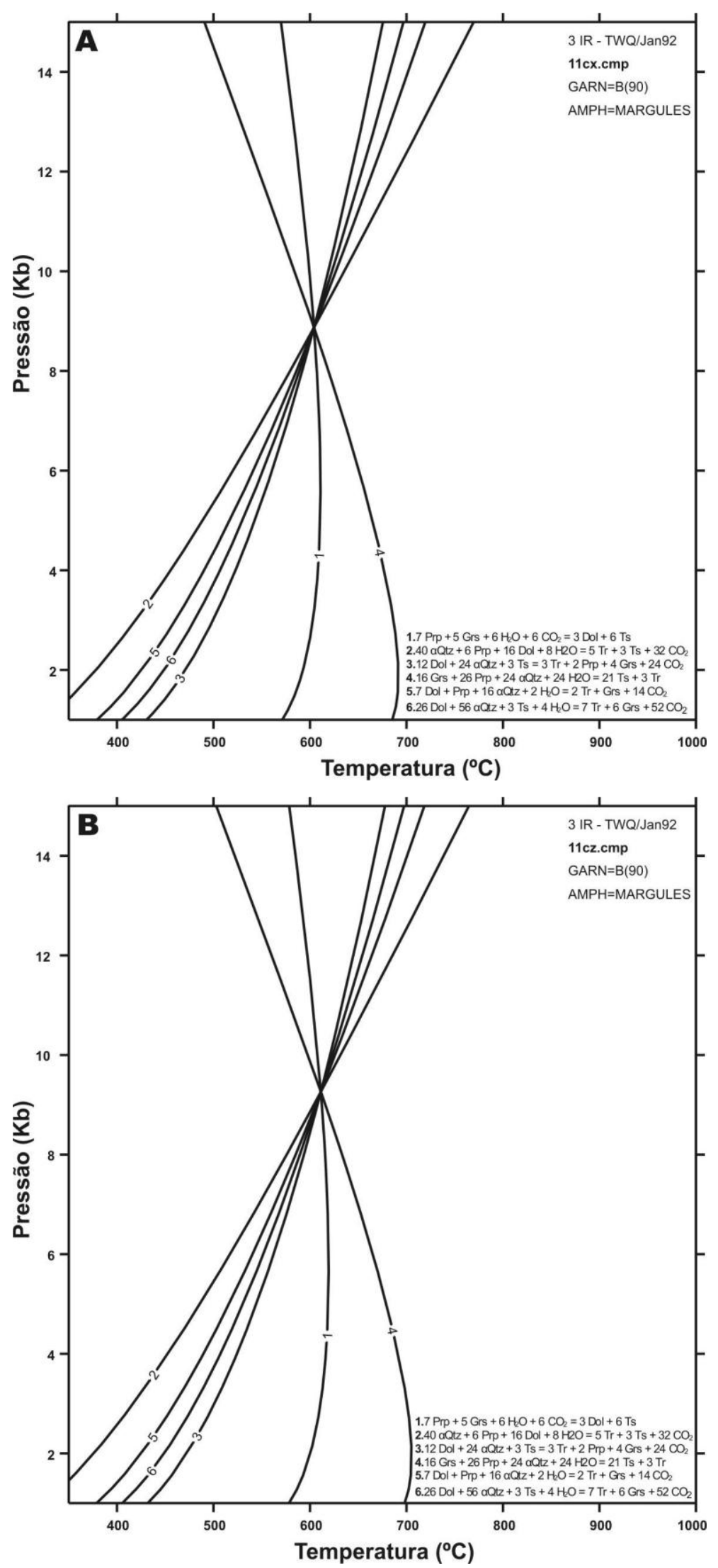

Figuras 27 A e B. Diagramas P-T obtidos para a amostra 11c com as análises em pontos intermediários da granada e o anfibólio, com $\mathrm{XCO}_{2}=0,4$ e $\mathrm{XH}_{2} \mathrm{O}=0,6$. 

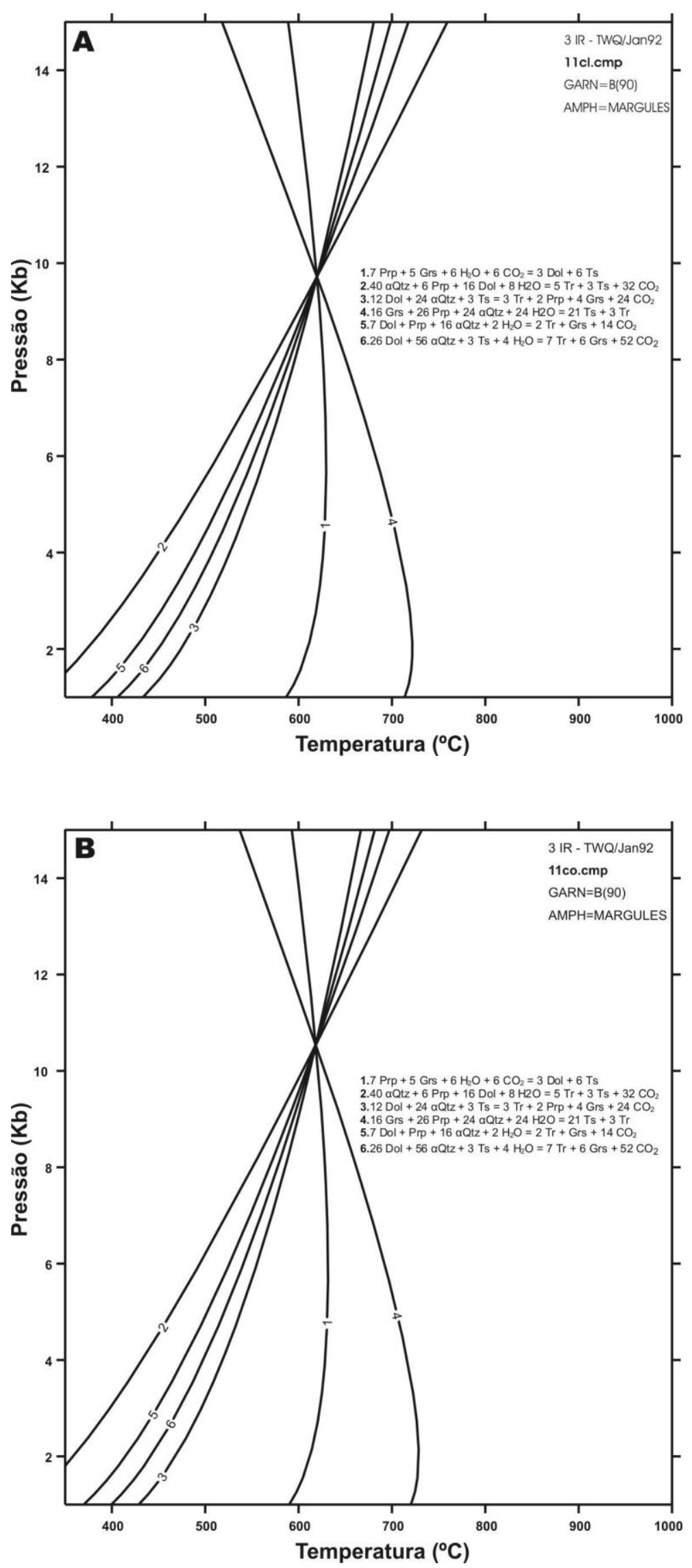

Figuras 28 A e B. Diagrama P-T obtido para a amostra 11c com as análises das bordas da granada e o anfibólio, com $\mathrm{XCO}_{2}=0,4$ e $\mathrm{XH}_{2} \mathrm{O}=0,6$. 
Quando comparados os núcleos e bordas da associação granada-anfibólioplagioclásio, os resultados da amostra 12c apresentam-se um pouco mais equilibrados que os da amostra anterior, e os valores variam entre $\sim 11,8-13,5 \mathrm{kbar}$ e $\sim 602-632{ }^{\circ} \mathrm{C}$, valores estes concordantes com as condições de pressão e temperatura obtidas na amostra 11c (Figuras 29 e 30). Também foi obtido um resultado com condições de cristalização em 14,4 kbar e $\sim 634{ }^{\circ} \mathrm{C}$ (Figura 31) a partir da análise de dois pontos de borda de cristais de plagioclásio e anfibólio encontrados inclusos na granada, o qual representa, pelo seus isolamentos relativos da matriz e dos fluidos retrometamórficos, as mais altas condições metamórficas alcançadas por este conjunto de rochas.

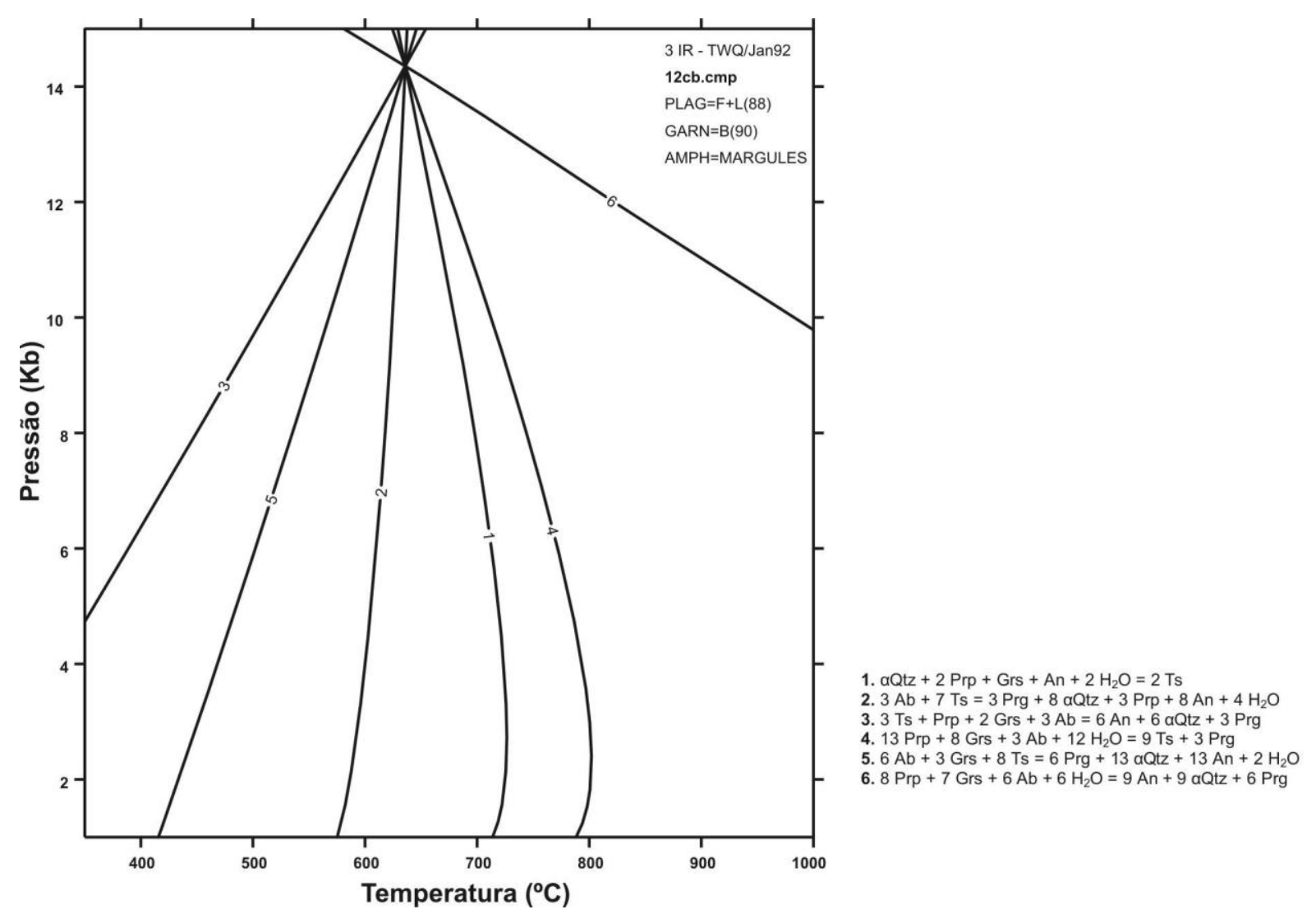

Figura 29. Diagramas P-T obtidos para a amostra 12c com as análises das bordas da granada, anfibólio e plagioclásio, com $\mathrm{XCO}_{2}=0,2$ e $\mathrm{XH}_{2} \mathrm{O}=0,8$. 


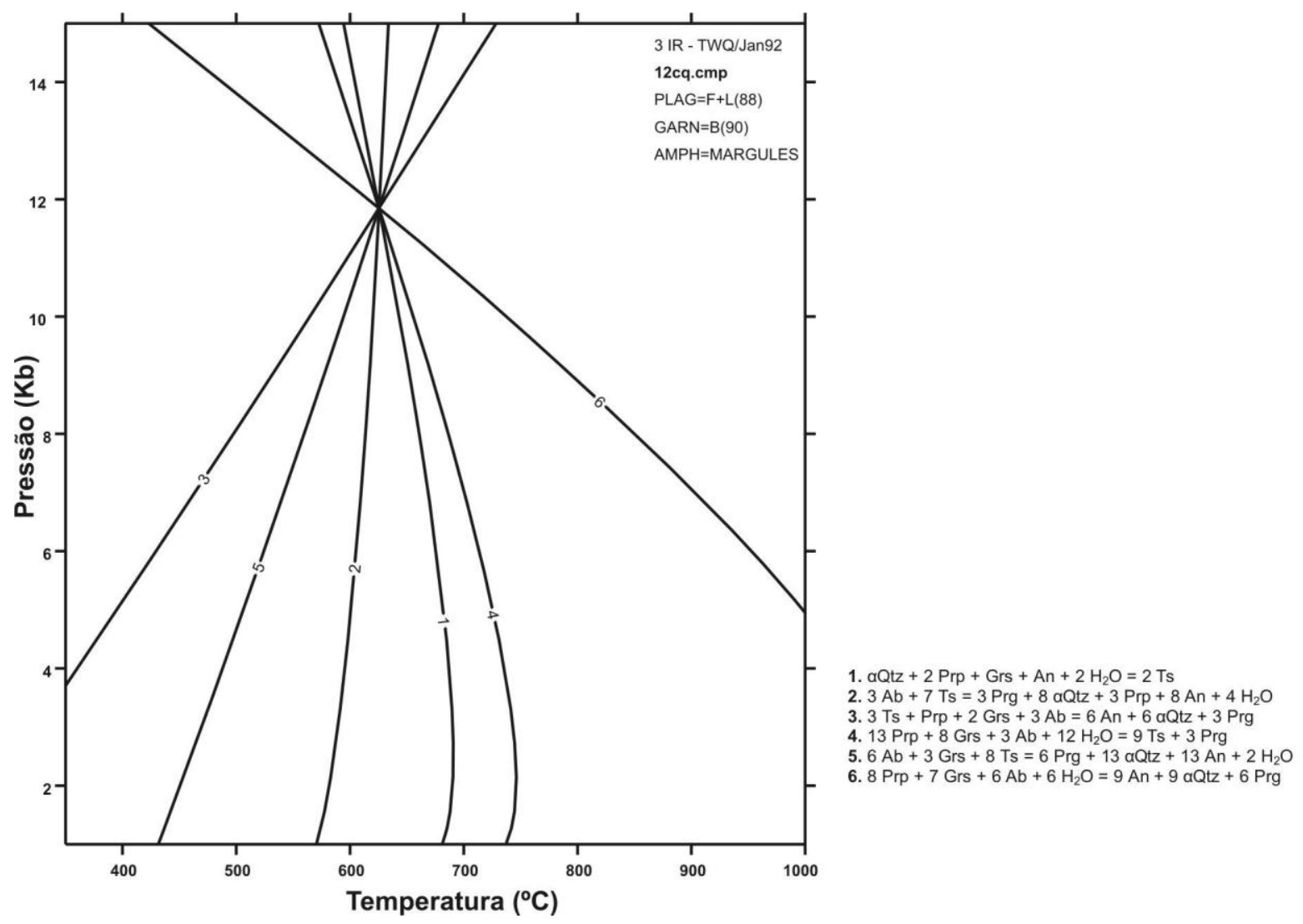

Figura 30. Diagramas P-T obtidos para a amostra 12c com as análises das bordas da granada, anfibólio e plagioclásio, com $\mathrm{XCO}_{2}=0,2$ e $\mathrm{XH}_{2} \mathrm{O}=0,8$.

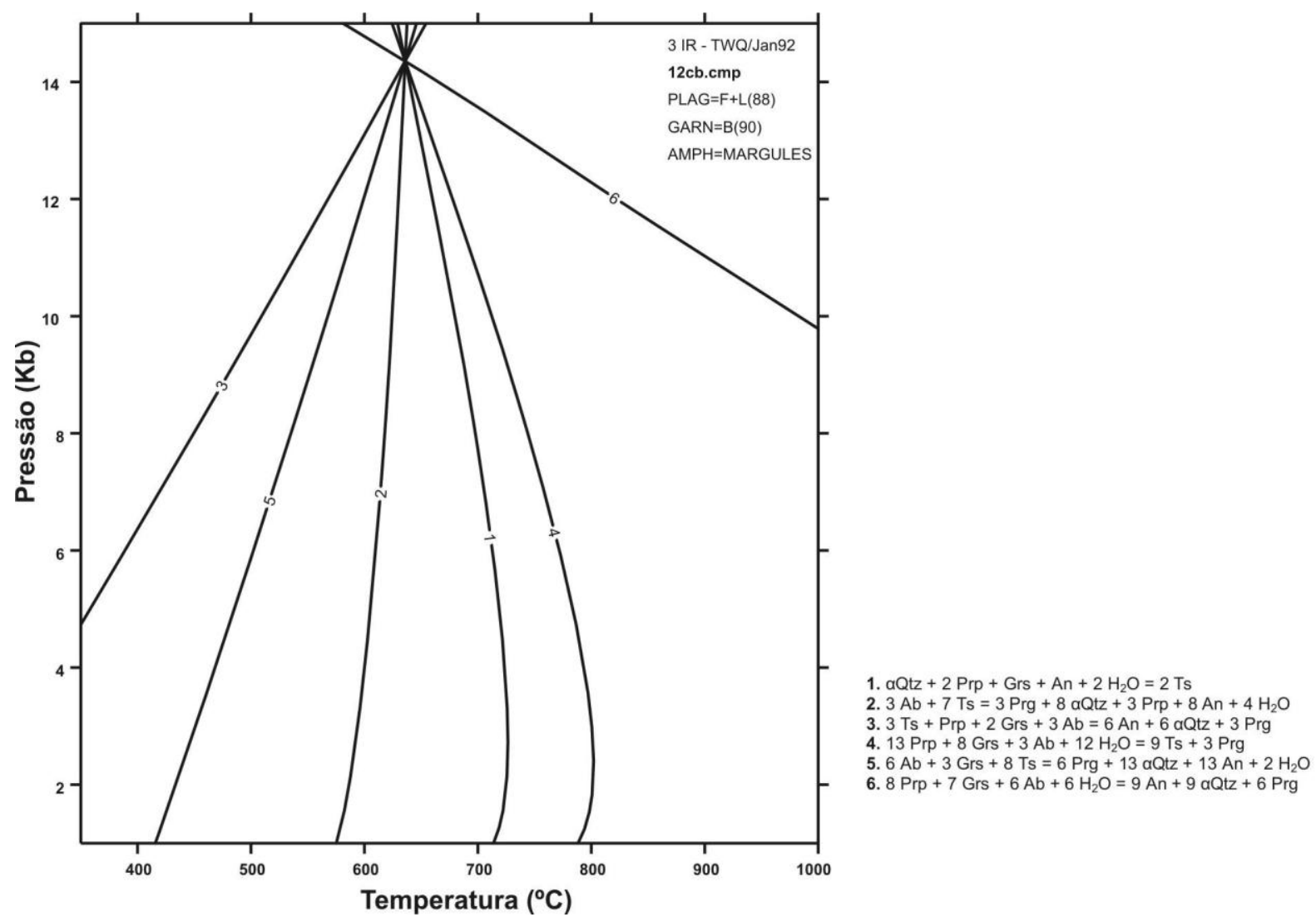

Figura 31. Diagramas P-T obtidos para a amostra 12c com as análises das bordas de anfibólio e plagioclásio como inclusão na granada, com $\mathrm{XCO}_{2}=0,2$ e $\mathrm{XH}_{2} \mathrm{O}=0,8$. 


\subsubsection{Amostra 20b}

A amostra apresenta uma foliação milonítica definida pela orientação do anfibólio e a granada é, em geral, porfiroblástica, tem parte da bordas com plagioclásio e clorita e está, às vezes, substituída, até totalmente, por anfibólio. Tal qual nas amostras 11c e 12c, foram feitos perfis composicionais em cristais de granada, anfibólio e plagioclásio. A granada não está em paragênese com o plagioclásio nem o anfibólio, mas todos três minerais distribuem-se em um único domínio microestrutural, justificando os cálculos geotermobarométricos apresentados a seguir.

Os resultados obtidos para esta amostra, apresentam algumas variações relativas aos cálculos feitos com as análises dos núcleos dos minerais, que dependem principalmente do uso do par granada-anfibólio. E da associação granada-anfibólioplagioclásio. O par granada-anfibólio resulta em condições que variam entre 6,3-6,5 kbar e 549-553 ํ (Figura 32) e a associação granada-anfibólio-plagioclásio entre $\sim 7,1-7,9$ kbar e $~ 536-549 \stackrel{\circ}{\circ}$ (Figuras 33 A e B).

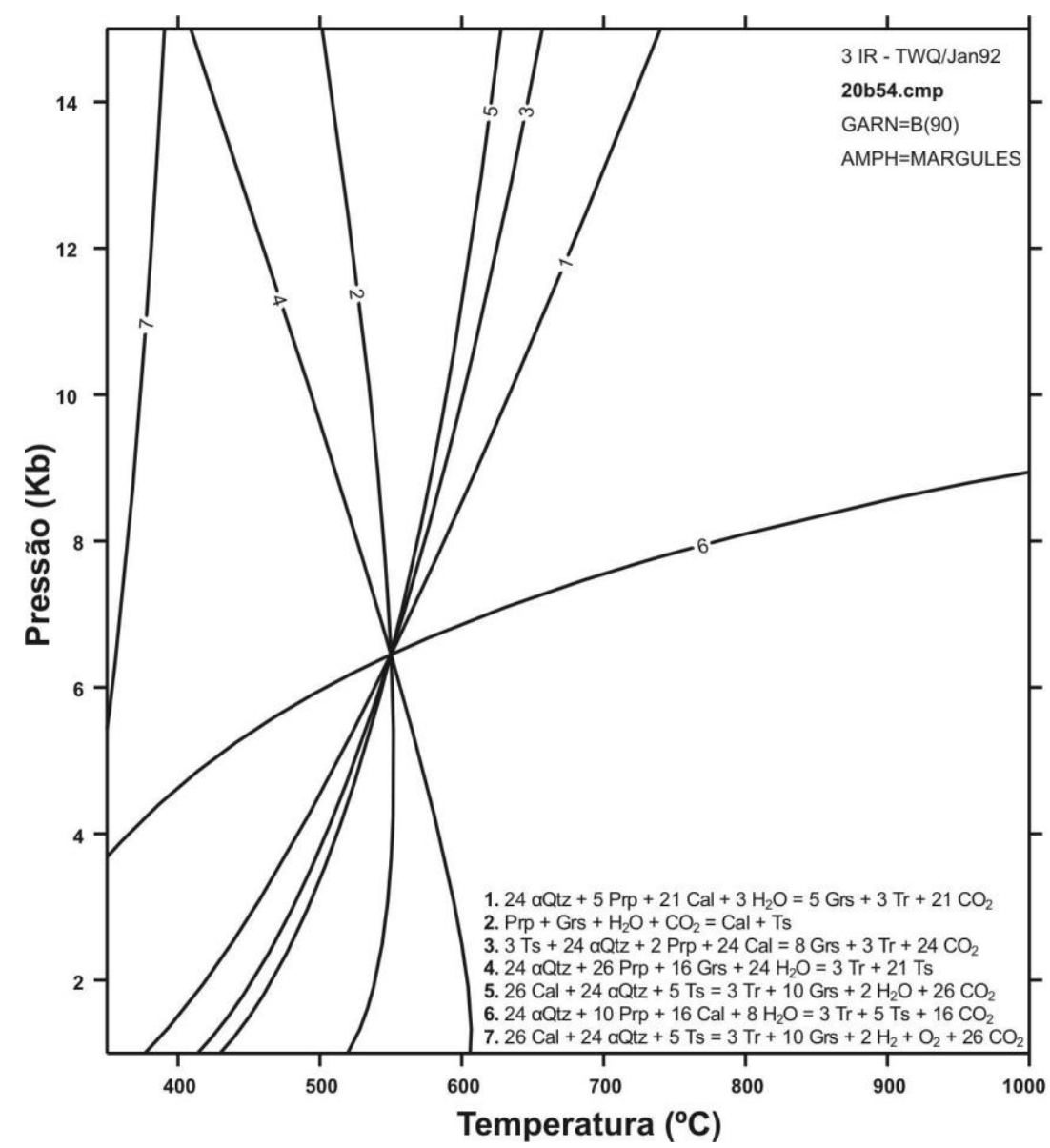

Figura 32. Diagrama P-T obtido para a amostra 20b com as análises dos núcleos da granada e o anfibólio, com $\mathrm{XCO}_{2}=0,1$ e $\mathrm{XH}_{2} \mathrm{O}=0,9$. 


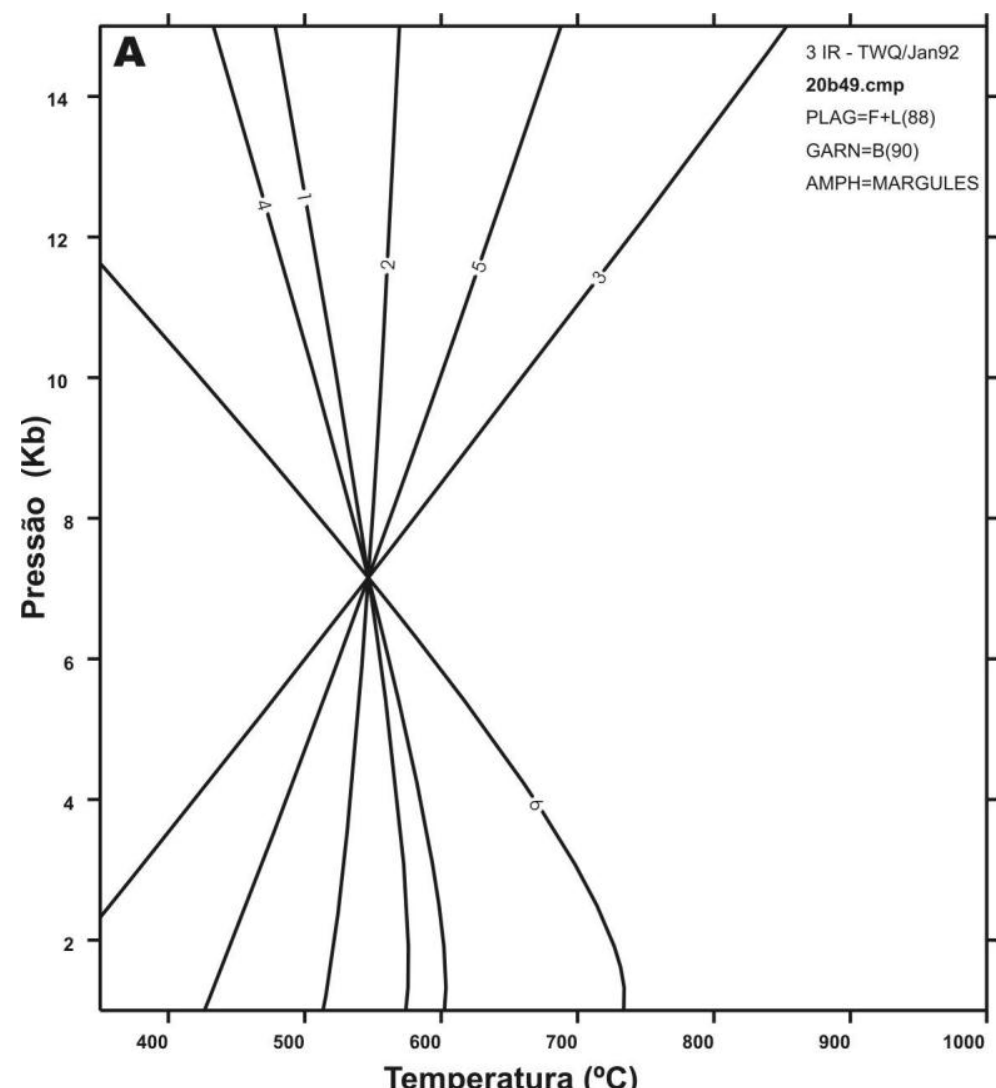

1. $\mathrm{aQtz}+2 \mathrm{Prp}+\mathrm{Grs}+\mathrm{An}+2 \mathrm{H}_{2} \mathrm{O}=2 \mathrm{Ts}$

2. $3 \mathrm{Ab}+7 \mathrm{Ts}=3 \mathrm{Prg}+8 \mathrm{aQtz}+3 \mathrm{Prp}+8 \mathrm{An}+4 \mathrm{H}_{2} \mathrm{O}$

3. $3 \mathrm{Ts}+\mathrm{Prp}+2 \mathrm{Grs}+3 \mathrm{Ab}=6 \mathrm{An}+6 \mathrm{aQtz}+3 \mathrm{Prg}$

5. $6 \mathrm{Ab}+3 \mathrm{Grs}+8 \mathrm{Ts}=6 \mathrm{Prg}+13 \mathrm{aQtz}+13 \mathrm{An}+2 \mathrm{H}_{2} \mathrm{O}$

6. $8 \mathrm{Prp}+7 \mathrm{Grs}+6 \mathrm{Ab}+6 \mathrm{H}_{2} \mathrm{O}=9 \mathrm{An}+9 \mathrm{aQz}+6 \mathrm{Prg}$

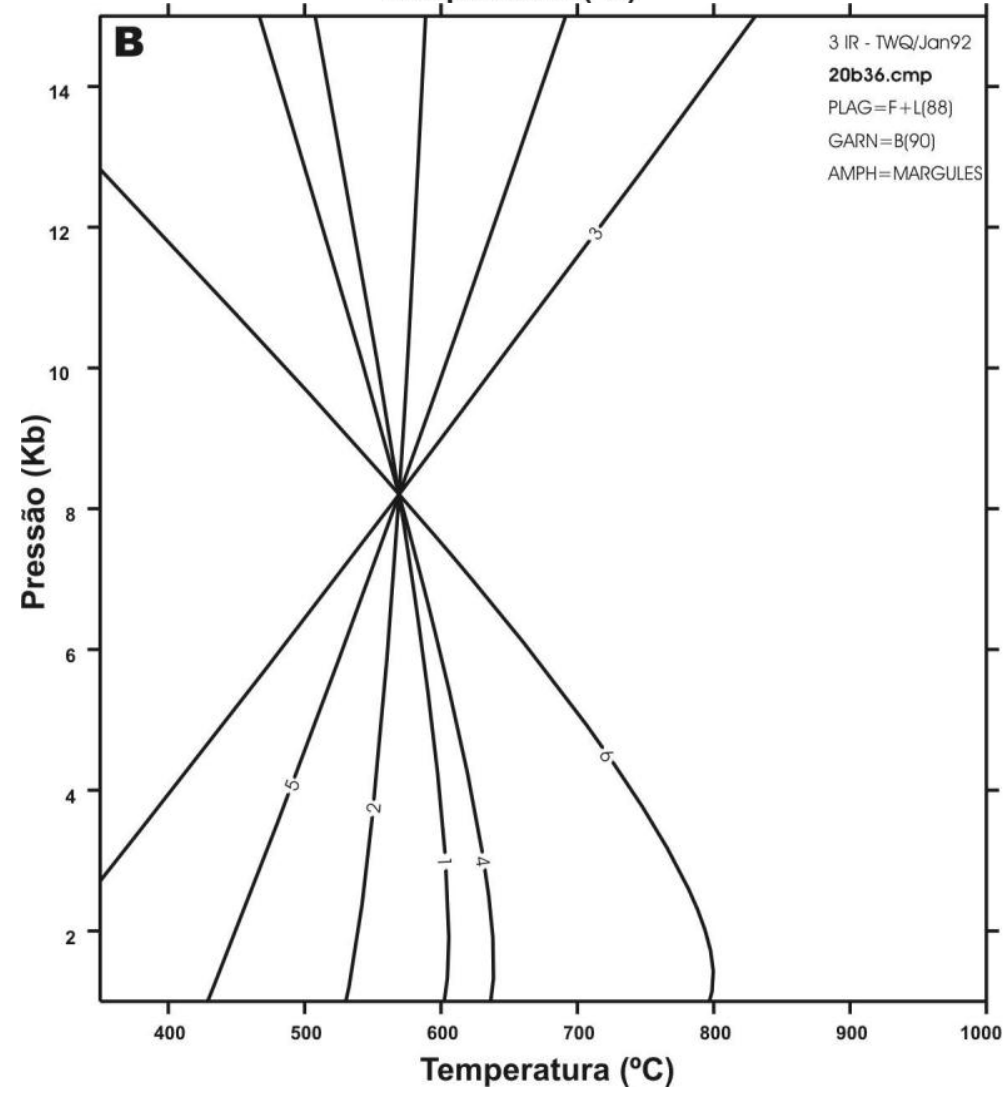

1. $\mathrm{aQtz}+2 \mathrm{Prp}+\mathrm{Grs}+\mathrm{An}+2 \mathrm{H}_{2} \mathrm{O}=2 \mathrm{Ts}$

2. $3 \mathrm{Ab}+7 \mathrm{Ts}=3 \mathrm{Prg}+8 \mathrm{aQtz}+3 \mathrm{Prp}+8 \mathrm{An}+4 \mathrm{H}_{2} \mathrm{O}$

3. 3 Ts + Prp + 2 Grs + 3 Ab $=6 \mathrm{An}+6 \mathrm{aQtz}+3 \mathrm{Prg}$

4. $13 \mathrm{Prp}+8 \mathrm{Grs}+3 \mathrm{Ab}+12 \mathrm{H}_{2} \mathrm{O}=9 \mathrm{Ts}+3 \mathrm{Prg}$

5. $6 \mathrm{Ab}+3 \mathrm{Grs}+8 \mathrm{Ts}=6 \mathrm{Prg}+13 \mathrm{aQtz}+13 \mathrm{An}+2 \mathrm{H}_{2} \mathrm{O}$

6. $8 \mathrm{Prp}+7 \mathrm{Grs}+6 \mathrm{Ab}+6 \mathrm{H}_{2} \mathrm{O}=9 \mathrm{An}+9 \mathrm{aQtz}+6 \mathrm{Prg}$

Figuras 33 A e B. Diagramas P-T obtidos para a amostra 20b com as análises dos núcleos da granada, anfibólio e plagioclásio, com $\mathrm{XCO}_{2}=0,1$ e $\mathrm{XH}_{2} \mathrm{O}=0,9$

Nos resultados obtidos com as bordas da associação granada-anfibólio- 
plagioclásio, observam-se dois conjuntos de valores, com variações significativas principalmente na pressão. O primeiro conjunto situa-se ao redor de $\sim 7,5-8,8 \mathrm{kbar} e$ 759-602 ำ e o segundo oscila entre 9,3-10,2 kbar e 549-577 ำ. Esta variação ocorre quando são utilizadas análises de plagioclásio com maiores teores de $\mathrm{Na}_{2} \mathrm{O}$, resultando em maior pressão, e menores conteúdos de $\mathrm{CaO}$, o que fazem com que a temperatura registrada seja mais baixa (Figuras 34, 35 A e B, e 36). É importante ressaltar, que estes resultados obtidos são compatíveis com os das amostras 11c e 12c, nos quais se observa um aumento da pressão e da temperatura de formação do núcleo para a borda.

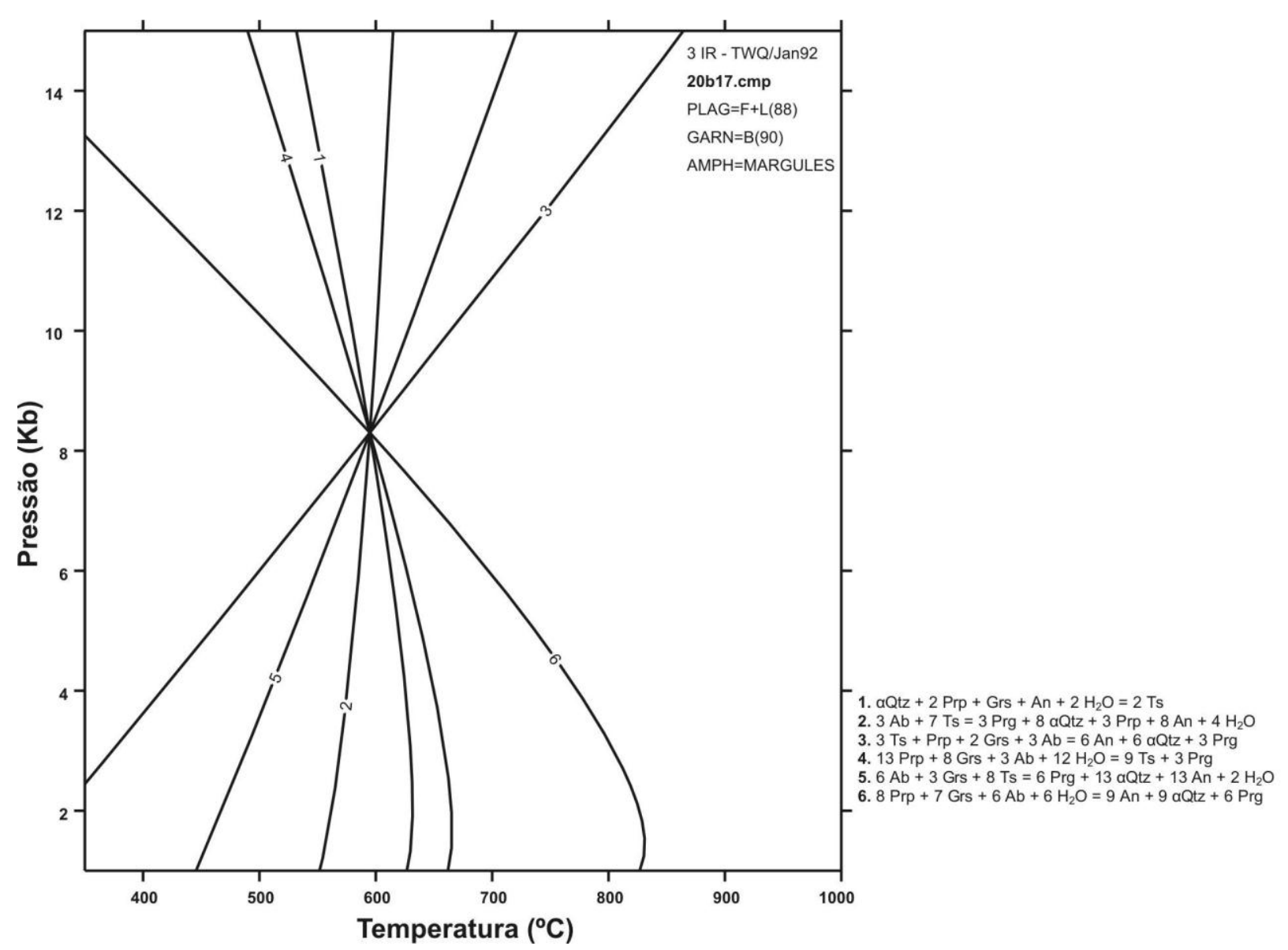

Figura 34. Diagrama P-T obtidos para a amostra 20b com as análises das bordas da granada, anfibólio e plagioclásio, $\operatorname{com} \mathrm{XCO}_{2}=0,1$ e $\mathrm{XH}_{2} \mathrm{O}=0,9$. 

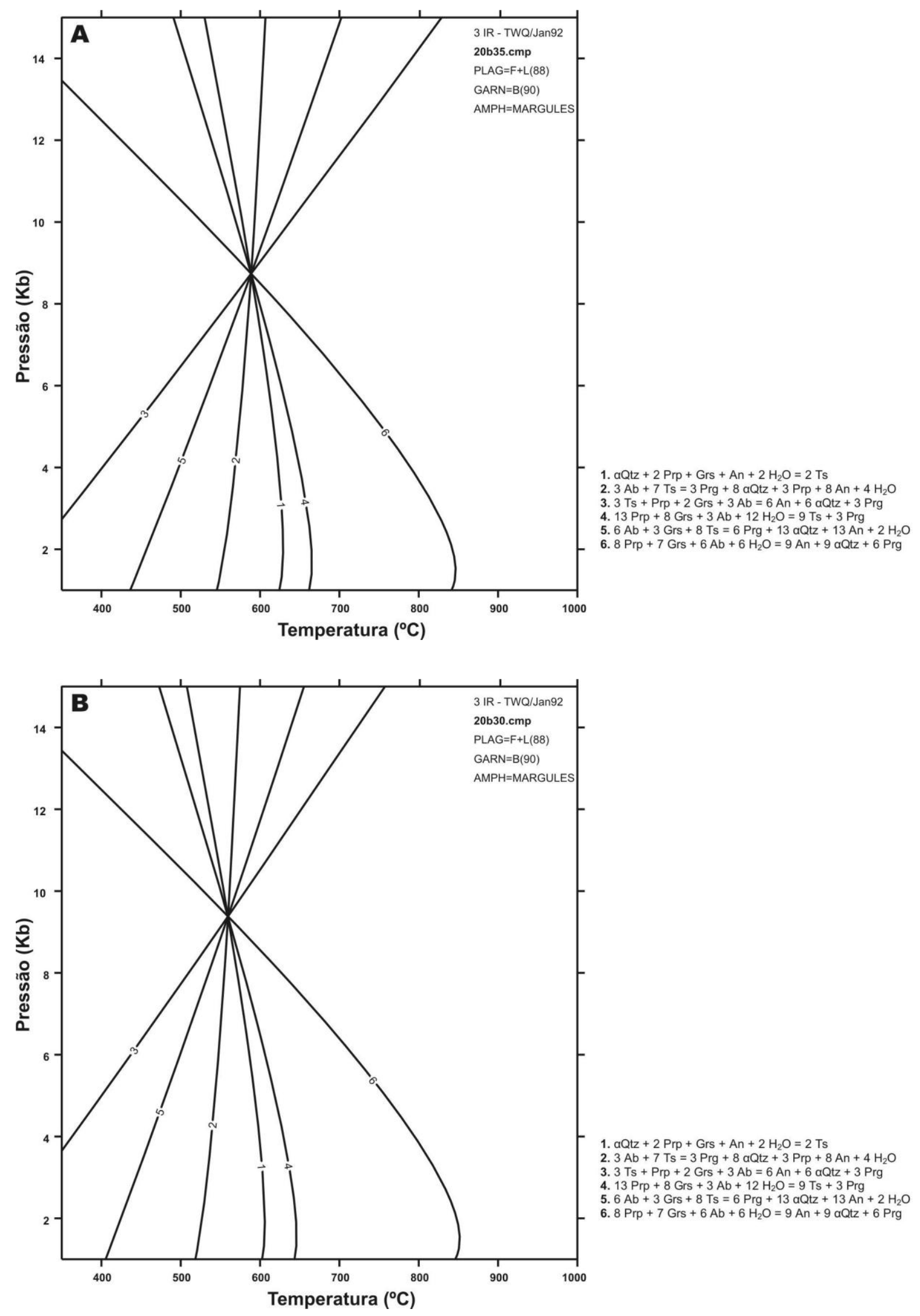

Figuras 35 A e B. Diagramas P-T obtidos para a amostra 20b com as análises das bordas da granada, anfibólio e plagioclásio, com $\mathrm{XCO}_{2}=0,1$ e $\mathrm{XH}_{2} \mathrm{O}=0,9$. 


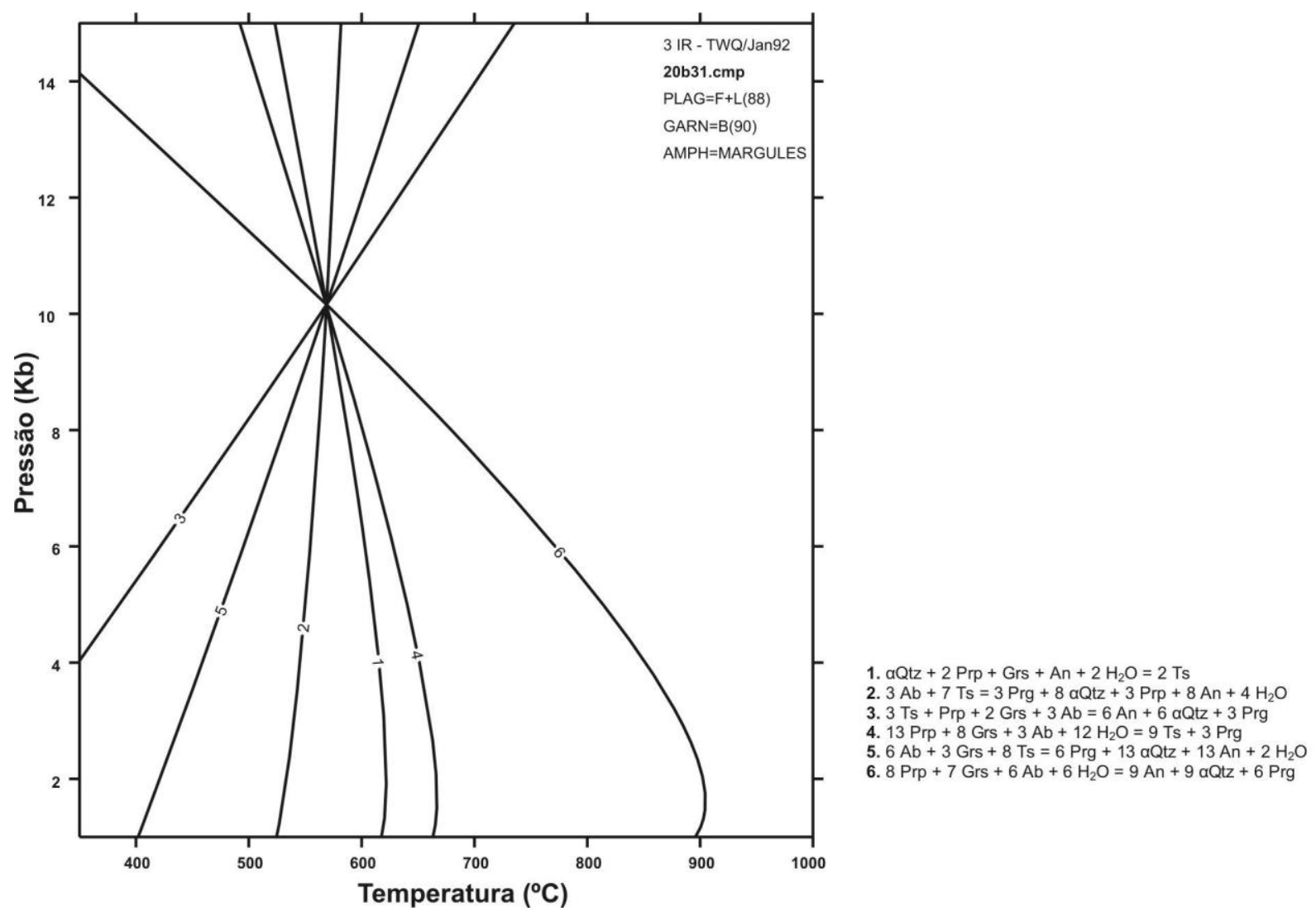

Figura 36. Diagrama P-T obtidos para a amostra $20 \mathrm{~b} c 0 m$ as análises das bordas da granada, anfibólio e plagioclásio, com $\mathrm{XCO}_{2}=0,1$ e $\mathrm{XH}_{2} \mathrm{O}=0,9$.

\subsection{Xistos de Ancón}

Nesta unidade foram analisados granada (com perfis composicionais), biotita, muscovita, clorita e estaurolita na seção 45b e granada, biotita, muscovita, plagioclásio e clorita na seção 46. Na seção 46, foram feitos cálculos mediante o uso do TWQ 2.02 com a associação granada-biotita-plagioclásio-muscovita, além do uso do geotermômetro granada-clorita (Dickenson \& Hewitt, 1986). Na seção 45b, não foi possível o uso do programa TWQ 2.02, devido à ausência de plagioclásio. Assim foram utilizados os geotermômetros granada-clorita (Dickenson \& Hewitt, 1986) e estaurolitagranada (Perchuk, 1991).

\subsubsection{Amostra 45b}

A rocha apresenta uma xistosidade bem definida pela orientação da muscovitasericita e, às vezes, com biotita associada. A granada é porfiroblástica, com cristais com hábito idioblástico ou subidioblástico, e pode ter poucas inclusões de outros minerais. A biotita faz parte da foliação e, às vezes, está em paragênese com a granada. A estaurolita, apresenta-se porfiroblástica e xenoblástica e pode conter 
inclusões de biotita e quartzo. A granada, apresenta fortes zonamentos de FeO e $\mathrm{MnO}$ e zonamentos mais discretos de $\mathrm{MgO}$ e $\mathrm{CaO}$ (Figura 13). A estaurolita apresenta composição química relativamente homogênea.

Os resultados obtidos com o geotermômetro estaurolita-granada (Perchuk, 1991) mostram claramente temperaturas mais altas na borda que no núcleo dos minerais. $O$ mesmo padrão é definido pelo geotermômetro granada-clorita de Dickenson \& Hewitt (1986), mas não puderam ser feitos perfis composicionais nos cristais de clorita que permitissem uma avaliação tão detalhada quanto a feita com o par estaurolita-granada.

As temperaturas obtidas com o par estaurolita-granada variam entre 460.5-561.2 ㄷ Com uma pressão constante de $5 \mathrm{kbar}, 464.5-565.8 \stackrel{\circ}{\mathrm{C}}$ com pressão constante de 7 kbar e 468.6-570.4 ํㅡ a 9 kbar e com um margem de erro de $\pm 50{ }^{\circ} \mathrm{C}$ o qual pertence à calibração apresentada por Perchuk (1991).

As temperaturas mais baixas são obtidas com as análises dos núcleos dos minerais e as temperaturas maiores com as de bordas. Entretanto, um discreto resfriamento retrometamórfico é ainda detectado no limite externo extremo dos minerais (Tabela 2, Figura 37).

Tabela 2. Temperaturas obtidas a partir do termômetro estaurolita-granada na amostra 45b. As colunas em cor cinza correspondem aos dados da estaurolita. ( ${ }^{*}$ pontos centrais do par).

\begin{tabular}{|c|c|c|c|c|c|c|c|c|c|c|}
\hline & St & & & Grt & & & & & & \\
\hline par usado & $\begin{array}{c}\% \mathrm{Fe} \\
\text { medido }\end{array}$ & $\begin{array}{c}\% M g \\
\text { medido }\end{array}$ & Xmg & $\begin{array}{c}\% \mathrm{Fe} \\
\text { medido }\end{array}$ & $\begin{array}{c}\% \mathrm{Mg} \\
\text { medido }\end{array}$ & Xmg & $K_{D}$ & $\begin{array}{c}\text { Too } \\
\text { (5Kb) }\end{array}$ & $\begin{array}{l}\text { Too } \\
\text { (7Kb) }\end{array}$ & $\begin{array}{l}\text { To } \mathrm{C} \\
(9 \mathrm{~Kb})\end{array}$ \\
\hline 248-161 & 1.471 & 0.277 & 0.158 & 4.520 & 0.526 & 0.104 & 1.618 & 553.8 & 558.3 & 562.9 \\
\hline $250-159^{*}$ & 1.514 & 0.292 & 0.162 & 3.298 & 0.259 & 0.073 & 2.456 & 460.5 & 464.5 & 468.6 \\
\hline 251-169 & 1.458 & 0.284 & 0.163 & 3.647 & 0.305 & 0.077 & 2.329 & 471.1 & 475.2 & 479.4 \\
\hline 252-157 & 1.42 & 0.273 & 0.161 & 4.581 & 0.507 & 0.100 & 1.737 & 536.3 & 540.7 & 545.2 \\
\hline $252-168$ & 1.42 & 0.273 & 0.161 & 4.498 & 0.539 & 0.107 & 1.604 & 555.9 & 560.5 & 565.1 \\
\hline 252-161 & 1.42 & 0.273 & 0.161 & 4.520 & 0.526 & 0.104 & 1.652 & 548.6 & 553.1 & 557.7 \\
\hline 248-168 & 1.471 & 0.277 & 0.158 & 4.498 & 0.539 & 0.107 & 1.571 & 561.2 & 565.8 & 570.4 \\
\hline $250-171^{\star}$ & 1.514 & 0.292 & 0.162 & 3.273 & 0.259 & 0.073 & 2.437 & 462.0 & 466.0 & 470.1 \\
\hline $251-166$ & 1.458 & 0.284 & 0.163 & 4.184 & 0.392 & 0.086 & 2.079 & 495.1 & 499.3 & 503.6 \\
\hline 251-165 & 1.458 & 0.284 & 0.163 & 3.694 & 0.292 & 0.073 & 2.464 & 459.8 & 463.8 & 467.9 \\
\hline 251-158 & 1.458 & 0.284 & 0.163 & 3.43 & 0.278 & 0.075 & 2.403 & 464.8 & 468.9 & 472.9 \\
\hline 251-163 & 1.458 & 0.284 & 0.163 & 3.312 & 0.268 & 0.075 & 2.407 & 464.4 & 468.5 & 472.6 \\
\hline $251-160$ & 1.458 & 0.284 & 0.163 & 3.557 & 0.291 & 0.076 & 2.381 & 466.7 & 470.7 & 474.8 \\
\hline 251-162 & 1.458 & 0.284 & 0.163 & 3.917 & 0.341 & 0.080 & 2.237 & 479.4 & 483.6 & 487.7 \\
\hline 251-170 & 1.458 & 0.284 & 0.163 & 3.38 & 0.267 & 0.073 & 2.466 & 459.7 & 463.7 & 467.8 \\
\hline 249-166 & 1.504 & 0.294 & 0.164 & 4.184 & 0.392 & 0.086 & 2.086 & 494.3 & 498.5 & 502.8 \\
\hline 249-165 & 1.504 & 0.294 & 0.164 & 3.694 & 0.292 & 0.073 & 2.473 & 459.1 & 463.1 & 467.2 \\
\hline 249-158 & 1.504 & 0.294 & 0.164 & 3.43 & 0.278 & 0.075 & 2.412 & 464.1 & 468.1 & 472.2 \\
\hline 249-162 & 1.504 & 0.294 & 0.164 & 3.917 & 0.341 & 0.080 & 2.245 & 478.7 & 482.8 & 487.0 \\
\hline 249-160 & 1.504 & 0294 & 0.164 & 3.557 & 0.291 & 0.076 & 2.389 & 465.9 & 470.0 & 474.1 \\
\hline 249-163 & 1.504 & 0.294 & 0.164 & 3.312 & 0.268 & 0.075 & 2.416 & 463.7 & 467.8 & 471.9 \\
\hline $250-167^{\star}$ & 1.514 & 0.292 & 0.162 & 3.408 & 0.271 & 0.074 & 2.425 & 462.9 & 467.0 & 471.1 \\
\hline $250-164^{\star}$ & 1.514 & 0.292 & 0.162 & 3.288 & 0.265 & 0.075 & 2.393 & 465.6 & 469.7 & 473.8 \\
\hline 248-157 & 1.471 & 0.277 & 0.158 & 4.581 & 0.507 & 0.100 & 1.701 & 541.3 & 545.8 & 550.3 \\
\hline 249-170 & 1.504 & 0.294 & 0.164 & 3.38 & 0.267 & 0.073 & 2.475 & 459.0 & 463.0 & 467.1 \\
\hline 249-169 & 1.504 & 0.294 & 0.164 & 3.647 & 0.305 & 0.077 & 2.337 & 470.4 & 474.5 & 478.6 \\
\hline
\end{tabular}




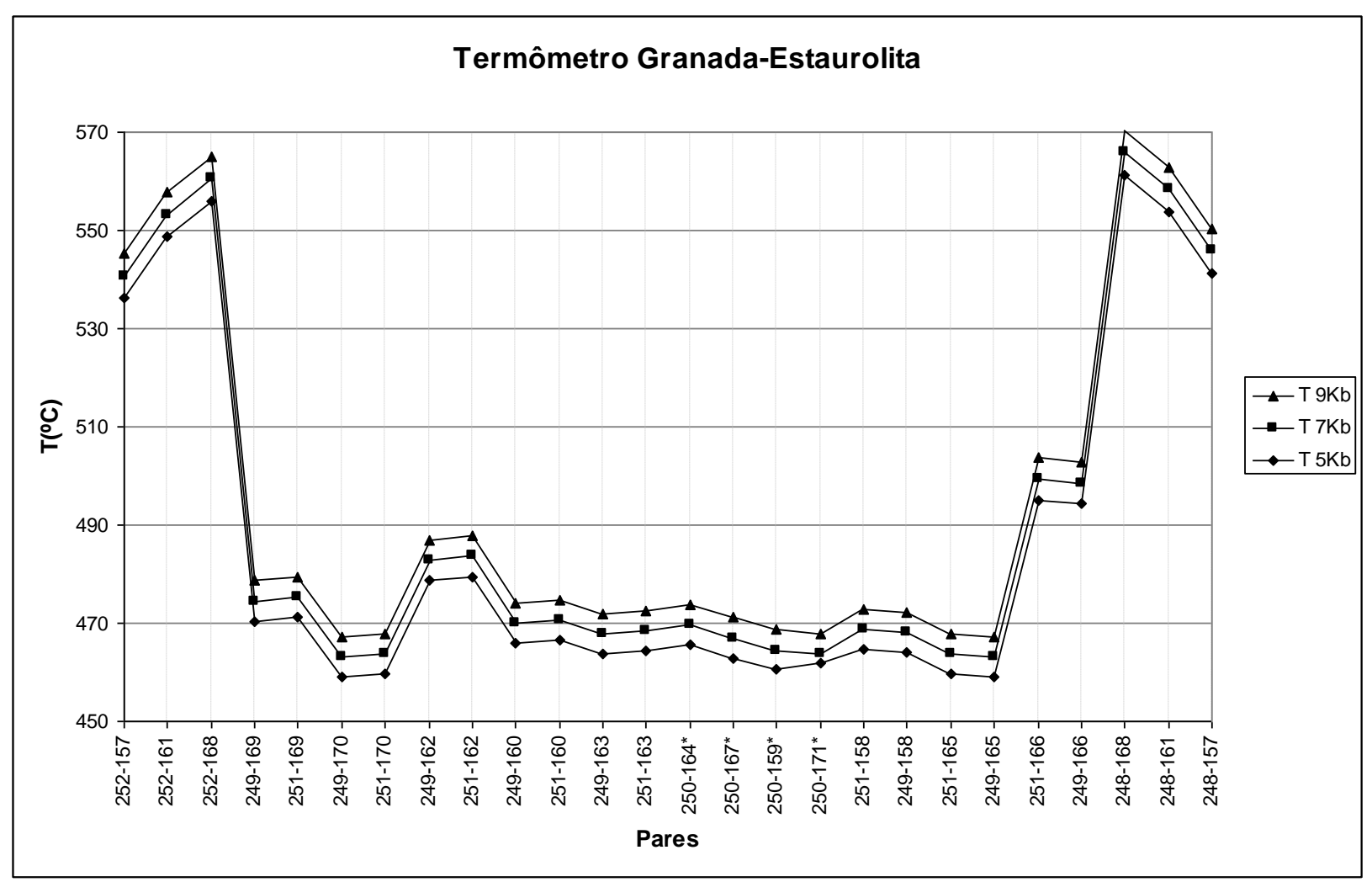

Figura 37. Distribuição das temperaturas de borda a borda dos pares usados obtidas com o termômetro estaurolita-granada.

Com o uso do par granada-clorita, foram confirmados os dados obtidos com o outro termômetro estaurolita-granada, observando-se temperaturas mais baixas nos núcleos e mais altas nas bordas dos minerais. Considerando a pressão de 6 kbar, obtem-se temperaturas que variam entre 397.1-497.8 ${ }^{\circ} \mathrm{C} ; 407.9-510.6{ }^{\circ} \mathrm{C}$ com pressão de 8 kbar e 418.7-522.6 com uma pressão fixa de 10 kbar (tabela 3).

Tabela 3. Temperaturas obtidas a partir do termômetro granada-clorita na amostra 45b. As colunas em cor cinza correspondem aos dados da granada.

\begin{tabular}{|c|c|c|c|c|c|c|c|c|c|c|}
\hline & Grt & & & Chl & & & & & & \\
\hline $\begin{array}{c}\text { par } \\
\text { usado }\end{array}$ & $\% \mathrm{Fe}$ & $\% \mathbf{M g}$ & $\mathrm{Mg} / \mathrm{Fe}$ & $\% \mathrm{Fe}$ & $\% \mathrm{Mg}$ & $\mathrm{Mg} / \mathrm{Fe}$ & $K_{D}$ & $\begin{array}{l}\mathrm{T}=\mathrm{C} \\
(6 \mathrm{~kb})\end{array}$ & $\begin{array}{c}\mathrm{T}\left({ }^{\circ} \mathrm{C}\right) \\
8 \mathrm{~kb}\end{array}$ & $\begin{array}{l}\mathrm{T}\left({ }^{\circ} \mathrm{C}\right) \\
10 \mathrm{~kb}\end{array}$ \\
\hline $194-208$ & 2.261 & 0.259 & 0.115 & 4.455 & 4.252 & 0.954 & 0.120 & 497.8 & 510.2 & 522.6 \\
\hline 194-207 & 2.261 & 0.259 & 0.115 & 4.478 & 4.268 & 0.953 & 0.120 & 498.3 & 510.6 & 523.0 \\
\hline $194-211$ & 2.261 & 0.259 & 0.115 & 4.443 & 4.332 & 0.975 & 0.117 & 490.9 & 503.2 & 515.5 \\
\hline $195-212$ & 2.036 & 0.172 & 0.084 & 4.448 & 4.309 & 0.969 & 0.087 & 406.3 & 417.3 & 428.2 \\
\hline $196-210$ & 1.855 & 0.150 & 0.081 & 4.504 & 4.334 & 0.962 & 0.084 & 397.1 & 407.9 & 418.7 \\
\hline
\end{tabular}

\subsubsection{Amostra 46}

A amostra apresenta uma foliação definida pelo arranjo dos cristais de biotita e muscovita. A granada mostra-se porfiroblástica, intensamente fraturada e parcialmente substituída ao longo das fraturas por biotita e clorita. Os cristais apresentam inclusões 
de biotita, quartzo, e minerais opacos. O plagioclásio é subidioblástico, está em paragênese com biotita e distribui-se no mesmo domínio microestrutural da granada. Os resultados obtidos com a associação granada-biotita-plagioclásio-muscovita, evidenciam equilíbrios ao redor de $\sim 7,2-7,4$ kbar e $\sim 635-639 \stackrel{\circ}{C}$ para as análise das bordas dos minerais (Figura 38).

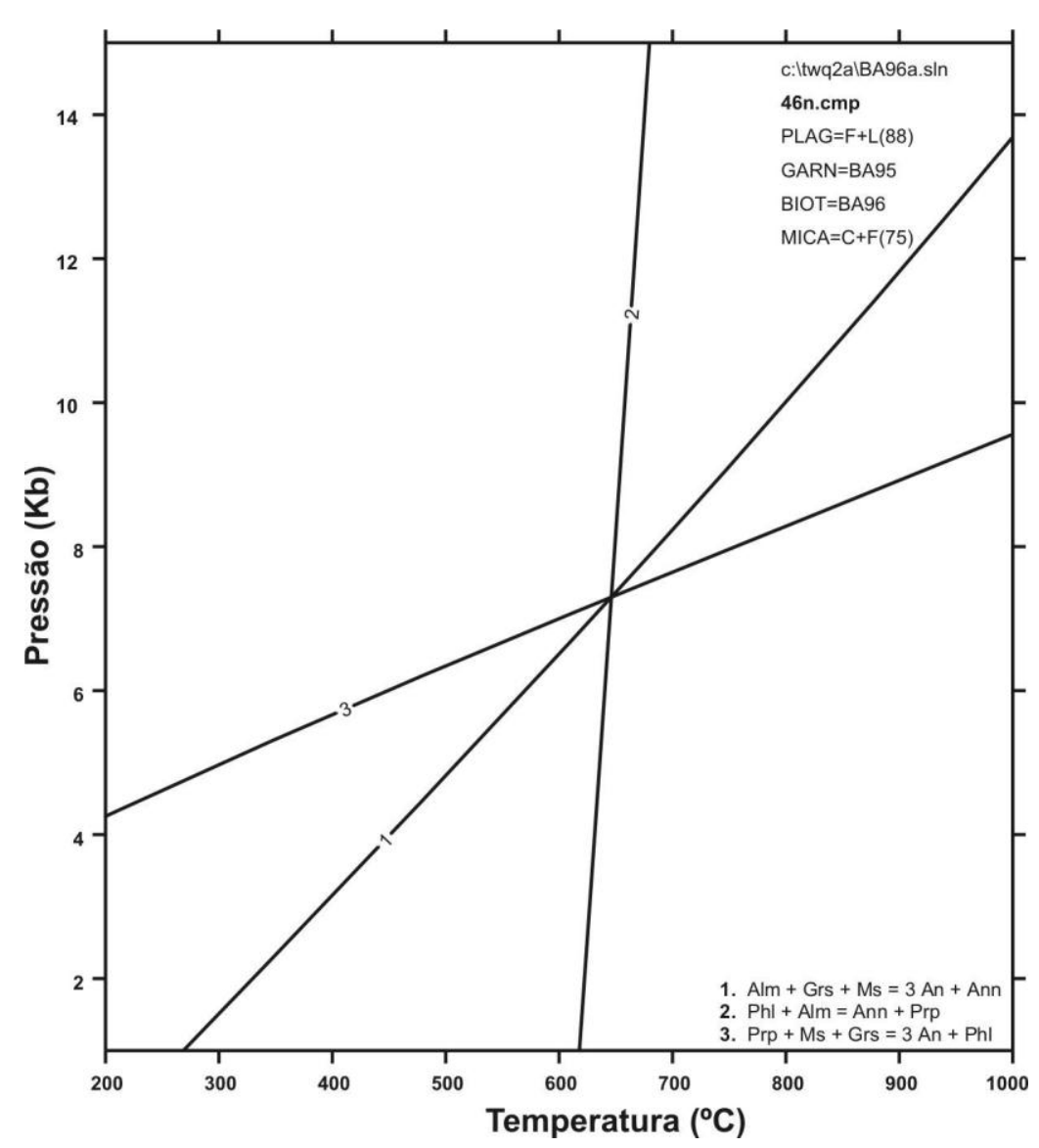

Figura 38. Diagrama P-T obtido para a amostra $46 \mathrm{com}$ as análises das bordas da granada, biotita, muscovita e plagioclásio, com $\mathrm{XCO}_{2}=0$ e $\mathrm{XH}_{2} \mathrm{O}=1,0$.

Quando analisados os núcleos do minerais, os resultados obtidos apresentam pouca variação, observando-se equilíbrios oscilando entre $\sim 7,4-7,6$ kbar e $\sim 643{ }^{\circ} \mathrm{C}$, evidenciando uma homogeneização relativa da fase inicial de cristalização (Figuras 39 $A$ e $B)$. 

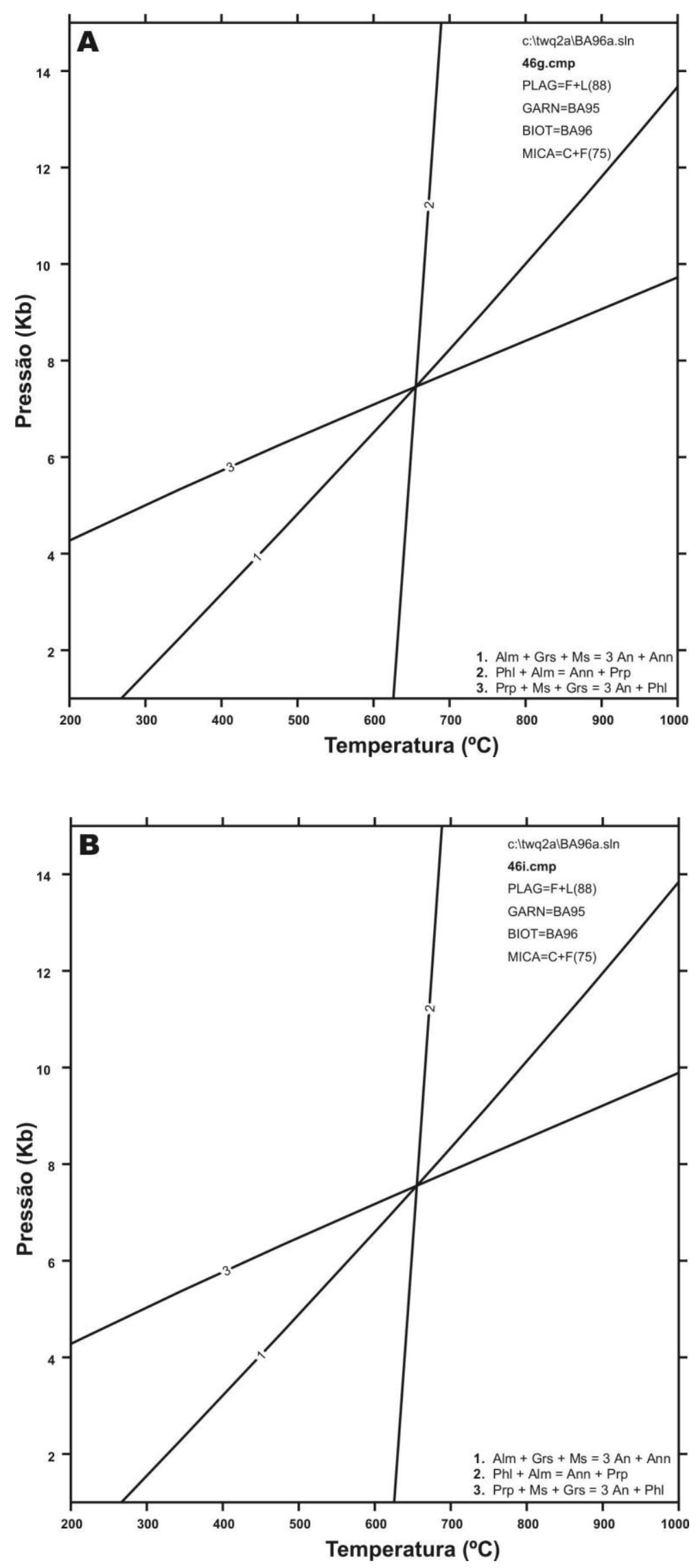

Figuras 39 A e B. Diagrama P-T obtido para a amostra $46 \mathrm{com}$ as análises das bordas da granada, biotita, muscovita e plagioclásio, com XCO2 $=0$ e $\mathrm{XH} 2 \mathrm{O}=1,0$. 
Mediante o uso do geotermômetro granada-clorita obtiveram-se resultados que corroboram as temperaturas um pouco mais altas $\left(\sim 627,1{ }^{\circ} \mathrm{C}\right)$ nos núcleos dos minerais, com condições de cristalização das bordas variando entre $\sim 581$ e $594 \stackrel{\circ}{\circ}$. As temperaturas para esta amostra apresentam variações entre 494-599.1 ํ C com uma pressão constante de 6 kbar. Com 8 kbar de pressão os resultados variam entre 506.3 - 613.1 ํ e com pressão de 10 kbar a variação é de 518.6 - $627.1 \stackrel{\circ}{\circ}$ (tabela 4).

Tabela 4. Temperaturas obtidas a partir do termômetro granada-clorita na amostra 46. As colunas em cor cinza correspondem aos dados da granada.

\begin{tabular}{|c|c|c|c|c|c|c|c|c|c|c|}
\hline & Grt & & & Chl & & & & & & \\
\hline $\begin{array}{c}\text { par } \\
\text { usado }\end{array}$ & $\% \mathrm{Fe}$ & $\% \mathrm{Mg}$ & $\mathrm{Mg} / \mathrm{Fe}$ & $\% \mathrm{Fe}$ & $\% \mathbf{M g}$ & $\mathrm{Mg} / \mathrm{Fe}$ & $K_{D}$ & $\begin{array}{c}\text { ToC } \\
(6 \mathrm{~kb})\end{array}$ & $\begin{array}{c}\text { ToC } \\
(8 \mathrm{~kb})\end{array}$ & $\begin{array}{c}\mathrm{T}^{\circ} \mathrm{C} \\
(10 \mathrm{~kb})\end{array}$ \\
\hline $184-218$ & 2.321 & 0.242 & 0.104 & 5.388 & 3.707 & 0.688 & 0.152 & 581.8 & 595.6 & 609.3 \\
\hline $187-220$ & 2.367 & 0.241 & 0.102 & 5.505 & 3.545 & 0.644 & 0.158 & 599.1 & 613.1 & 627.1 \\
\hline $185-219$ & 2.390 & 0.210 & 0.088 & 5.327 & 3.736 & 0.701 & 0.125 & 512.0 & 524.6 & 537.2 \\
\hline $185-221$ & 2.390 & 0.210 & 0.088 & 5.243 & 3.884 & 0.741 & 0.119 & 494.0 & 506.3 & 518.6 \\
\hline $186-221$ & 2.386 & 0.224 & 0.094 & 5.243 & 3.884 & 0.741 & 0.127 & 515.9 & 528.6 & 541.2 \\
\hline $184-222$ & 2.321 & 0.242 & 0.104 & 5.359 & 3.695 & 0.689 & 0.151 & 581.0 & 594.7 & 608.4 \\
\hline $186-222$ & 2.386 & 0.224 & 0.094 & 5.359 & 3.695 & 0.689 & 0.136 & 541.1 & 554.2 & 567.3 \\
\hline $186-219$ & 2.386 & 0.224 & 0.094 & 5.327 & 3.736 & 0.701 & 0.134 & 535.0 & 548.0 & 560.9 \\
\hline $184-219$ & 2.321 & 0.242 & 0.104 & 5.327 & 3.736 & 0.701 & 0.149 & 574.2 & 587.8 & 601.5 \\
\hline $187-221$ & 2.367 & 0.241 & 0.102 & 5.243 & 3.884 & 0.741 & 0.137 & 544.5 & 557.6 & 570.8 \\
\hline $185-220$ & 2.390 & 0.210 & 0.088 & 5.505 & 3.545 & 0.6 & 0.136 & 541.9 & 554.9 & 568.0 \\
\hline $186-220$ & 2.386 & 0.224 & 0.094 & 5.505 & 3.545 & 0.644 & 0.146 & 566.6 & 580.1 & 593.6 \\
\hline
\end{tabular}

\subsection{Anfibolitos, Migmatitos e Granulitos de El Retiro}

Neste conjunto de rochas só foi possível a obtenção de dados de pressão e temperatura com minerais de duas das seções. Uma delas corresponde ao paleossoma do migmatito e a outra um sericita xisto com cloritóide. Nesta última amostra, foi usado o geotermômetro cloritóide-clorita (Vidal et al., 1999). Para o migmatito (seção 53) foram obtidos resultados mediante o uso do TWQ 2.02 aplicado à associação granada-biotita-muscovita-sillimanita.

Para as amostras ER2 e 854A não foi possível a obtenção de dados geotermobarométricos, pois para as paragêneses ortopiroxênio-plagioclásio-biotita, são poucas as calibrações existentes e o único possível geotermômetro utilizável [ortopiroxênio-biotita (Aranovich et al., 1988; Sengupta et al., 1990)] apresenta erros nas fórmulas publicadas. 


\subsubsection{Amostra 32d}

A amostra apresenta uma foliação definida pela sericita, com alguns cristais de quartzo alongados. O cloritóide constitui porfiroblastos subidioblásticos discordantes da xistosidade, evidenciando seu caráter pós-deformacional. A clorita apresenta-se como produto da substituição retrometamórfica da biotita. O geotermômetro cloritóide-clorita não é aplicável em minerais para composições muito ricas em Fe ou em $\mathrm{Mg}$, sendo útil apenas para cloritóide com $\mathrm{XMg}_{\mathrm{Cld}}<0,2$ e $\mathrm{XMg}_{\mathrm{Cld}}>0,8$ a $700 \stackrel{\circ}{\mathrm{C}}$, e $\mathrm{XMg}_{\mathrm{cld}}<0,1$ e $\mathrm{XMg}_{\mathrm{Cld}}>0,9$ a $300^{\circ} \mathrm{C}$. Para os pares cloritóide-clorita com $0,3<\mathrm{XMg}_{\mathrm{Cld}}>0,7 \mathrm{a}$ exatidão das temperaturas obtidas é de $\pm 60^{\circ} \mathrm{C}$. A variação do $\mathrm{K}_{\mathrm{D}}$ em função da pressão é pequena $\left(0,0008 \mathrm{kbar}\right.$ a $\left.750^{\circ} \mathrm{K}\right)$.

Nesta amostra, os valores de XMgcld variam entre 0,159-0,187, e os cálculos resultam em temperaturas entre 518-603 ํㅡ, sem variações significativas entre 0 núcleo e a borda dos minerais. Apenas são observáveis leves insinuações de temperaturas mais altas nos núcleos, quando comparados com as bordas (Tabela 5).

Tabela 5. Temperaturas obtidas a partir do termômetro cloritóide-clorita na amostra 32d. As colunas em cor cinza correspondem aos dados do cloritóide.

\begin{tabular}{|c|c|c|c|c|c|c|c|c|c|c|}
\hline & Cld & & & & Chl & & & & & \\
\hline par usado & $\% \mathrm{Fe}$ & $\% \mathbf{M g}$ & Xfe & Xmg & $\% \mathrm{Fe}$ & $\% \mathbf{M g}$ & Xfe & Xmg & $K_{D}$ & T으 \\
\hline 223-213 & 3.771 & 0.759 & 0.832 & 0.168 & 4.786 & 3.965 & 0.547 & 0.453 & 4.116 & 555.8 \\
\hline 223-215 & 3.771 & 0.759 & 0.832 & 0.168 & 4.850 & 4.002 & 0.548 & 0.452 & 4.100 & 557.2 \\
\hline 223-217 & 3.771 & 0.759 & 0.832 & 0.168 & 4.727 & 4.117 & 0.534 & 0.466 & 4.327 & 538.7 \\
\hline $224-214^{*}$ & 3.674 & 0.839 & 0.814 & 0.186 & 4.639 & 4.278 & 0.520 & 0.480 & 4.038 & 562.4 \\
\hline 224-216* & 3.674 & 0.839 & 0.814 & 0.186 & 4.812 & 4.013 & 0.545 & 0.455 & 3.652 & 599.5 \\
\hline 224-217* & 3.674 & 0.839 & 0.814 & 0.186 & 4.727 & 4.117 & 0.534 & 0.466 & 3.814 & 583.1 \\
\hline $225-216^{*}$ & 3.732 & 0.859 & 0.813 & 0.187 & 4.812 & 4.013 & 0.545 & 0.455 & 3.623 & 602.6 \\
\hline 226-216* & 3.705 & 0.850 & 0.813 & 0.187 & 4.812 & 4.013 & 0.545 & 0.455 & 3.635 & 601.3 \\
\hline $227-213$ & 3.754 & 0.739 & 0.836 & 0.164 & 4.786 & 3.965 & 0.547 & 0.453 & 4.208 & 548.1 \\
\hline 227-215 & 3.754 & 0.739 & 0.836 & 0.164 & 4.850 & 4.002 & 0.548 & 0.452 & 4.192 & 549.5 \\
\hline 227-217 & 3.754 & 0.739 & 0.836 & 0.164 & 4.727 & 4.117 & 0.534 & 0.466 & 4.424 & 531.4 \\
\hline 228-213 & 3.736 & 0.756 & 0.832 & 0.168 & 4.786 & 3.965 & 0.547 & 0.453 & 4.094 & 557.6 \\
\hline 228-215 & 3.736 & 0.756 & 0.832 & 0.168 & 4.850 & 4.002 & 0.548 & 0.452 & 4.078 & 559.0 \\
\hline 228-217 & 3.736 & 0.756 & 0.832 & 0.168 & 4.727 & 4.117 & 0.534 & 0.466 & 4.304 & 540.5 \\
\hline $229-213$ & 3.798 & 0.718 & 0.841 & 0.159 & 4.786 & 3.965 & 0.547 & 0.453 & 4.382 & 534.5 \\
\hline 229-215 & 3.798 & 0.718 & 0.841 & 0.159 & 4.850 & 4.002 & 0.548 & 0.452 & 4.365 & 535.9 \\
\hline 229-217 & 3.798 & 0.718 & 0.841 & 0.159 & 4.727 & 4.117 & 0.534 & 0.466 & 4.607 & 518.4 \\
\hline $230-213$ & 3.732 & 0.823 & 0.819 & 0.181 & 4.786 & 3.965 & 0.547 & 0.453 & 3.757 & 588.8 \\
\hline $230-215$ & 3.732 & 0.823 & 0.819 & 0.181 & 4.850 & 4.002 & 0.548 & 0.452 & 3.742 & 590.3 \\
\hline $230-217$ & 3.732 & 0.823 & 0.819 & 0.181 & 4.727 & 4.117 & 0.534 & 0.466 & 3.949 & 570.4 \\
\hline $231-213$ & 3.737 & 0.753 & 0.832 & 0.168 & 4.786 & 3.965 & 0.547 & 0.453 & 4.111 & 556.1 \\
\hline $231-214$ & 3.737 & 0.753 & 0.832 & 0.168 & 4.639 & 4.278 & 0.520 & 0.480 & 4.577 & 520.5 \\
\hline $231-215$ & 3.737 & 0.753 & 0.832 & 0.168 & 4.850 & 4.002 & 0.548 & 0.452 & 4.095 & 557.5 \\
\hline $231-217$ & 3.737 & 0.753 & 0.832 & 0.168 & 4.727 & 4.117 & 0.534 & 0.466 & 4.322 & 539.1 \\
\hline
\end{tabular}




\subsubsection{Amostra 53}

Esta rocha também apresenta uma foliação bem definida pelo arranjo da biotita e da muscovita, assim como uma crenulação com nova geração de biotita e algo de muscovita. Para os cálculos feitos nesta rocha, foram usadas biotita e muscovita que pertencem à foliação principal e alguns cristais inclusos na granada. A granada é porfiroblástica, possui inclusões de biotita, muscovita, sillimanita e quartzo, encontra-se estirada e está intensamente fraturada.

Os resultados obtidos a partir do uso de TWQ 2.02, indicam dois grupos diferentes de pressões e um de temperatura. As pressões variam entre $\sim 8,6-7,9 \mathrm{kbar}$ e 5,5-2,7 kbar e a temperatura oscila entre 742-633 ㅇ (Figuras 40, 41 A e B), resultados estes que são compatíveis para ocorrência de fusão parcial de rochas com composição granítica em nível crustal raso.

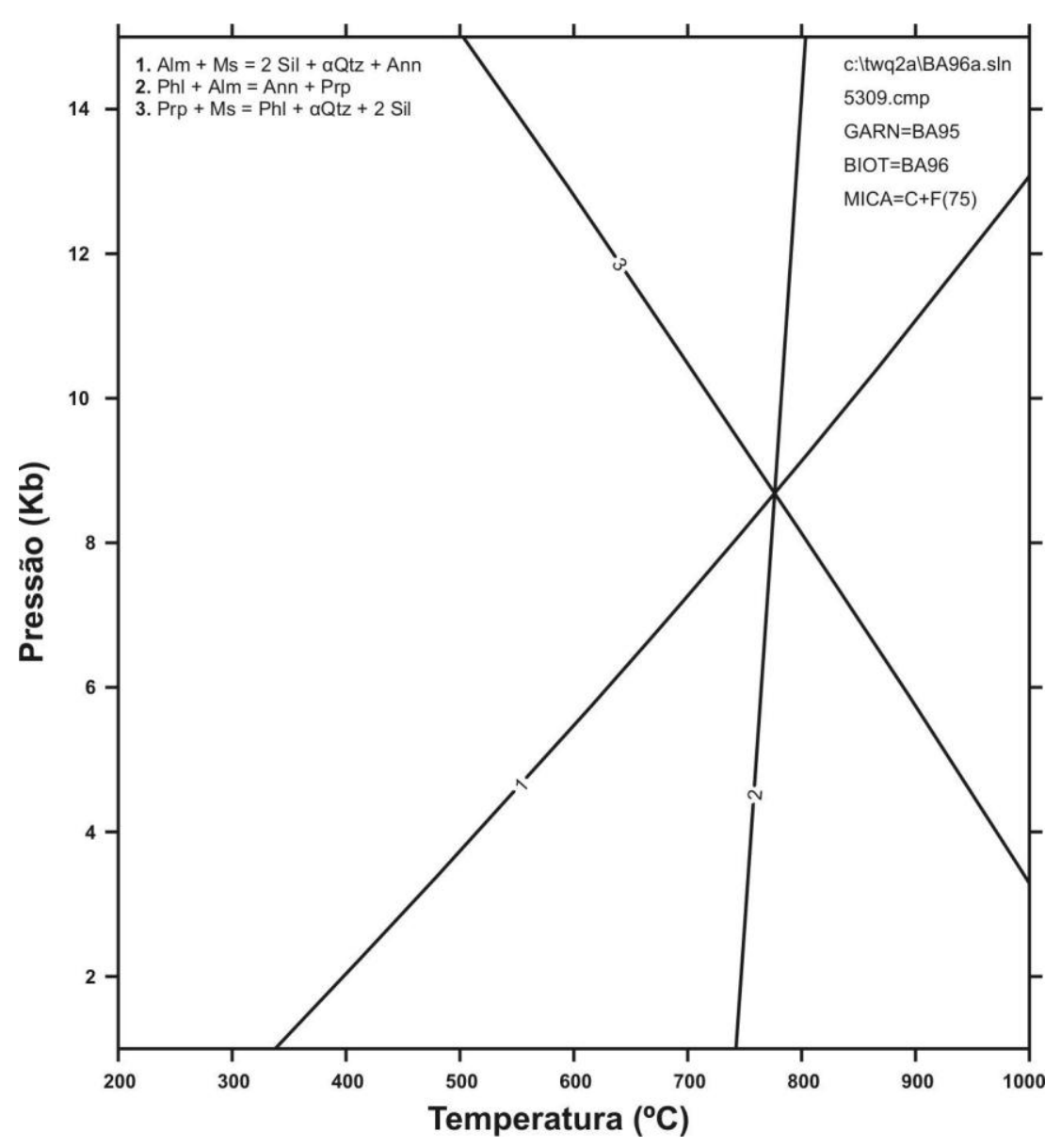

Figura 40. Diagrama P-T obtido para a amostra $53 \mathrm{com}$ as análises da associação granada, biotita e muscovita, com $\mathrm{XCO}_{2}=0$ e $\mathrm{XH}_{2} \mathrm{O}=1,0$. 

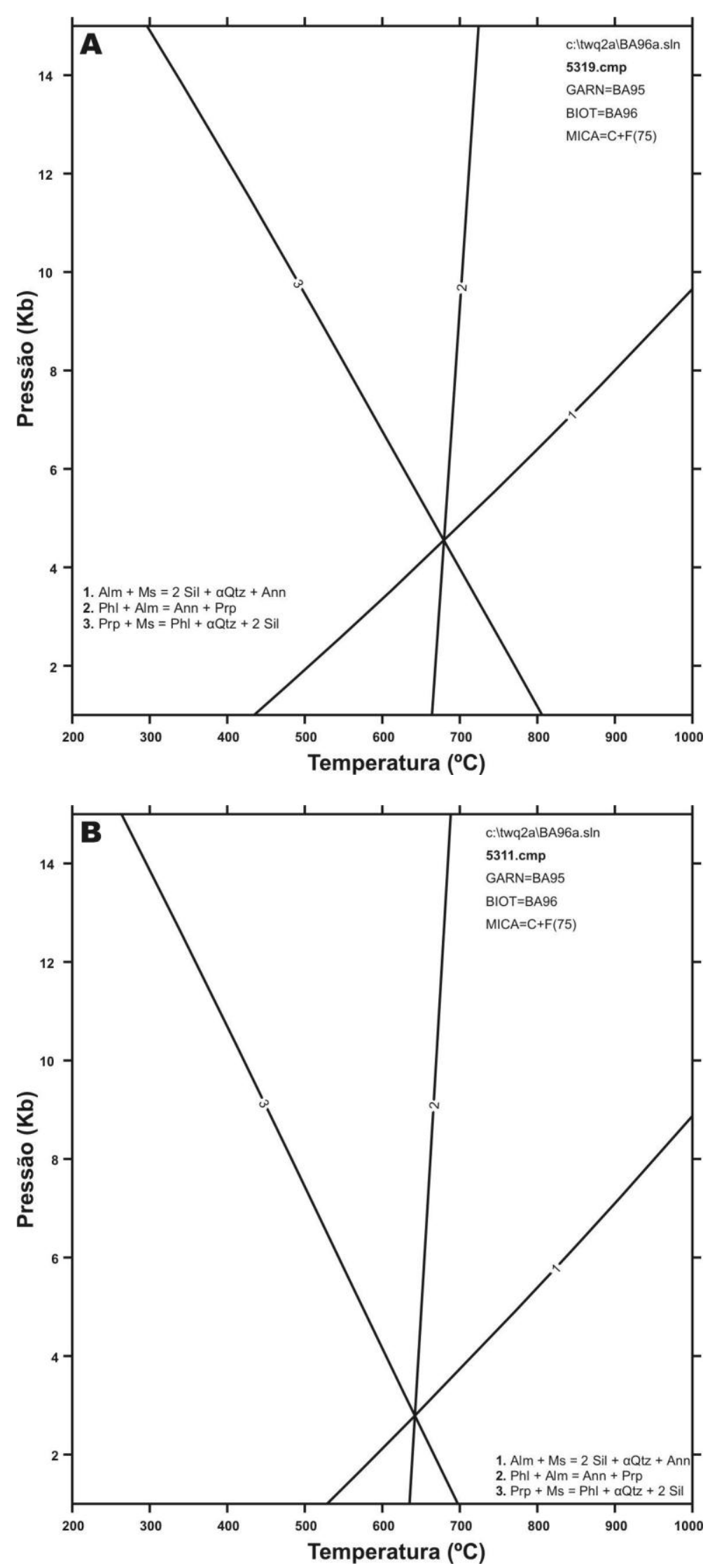

Figuras 41 A e B. Diagramas P-T obtidos para a amostra 53 com as análises da associação granada, biotita e muscovita, com $\mathrm{XCO}_{2}=0$ e $\mathrm{XH}_{2} \mathrm{O}=1,0$. 


\section{DISCUSSÃO}

Atualmente há falta de modelos que expliquem o metamorfismo na Cordilheira Central dos Andes da Colômbia, o que tem obrigado aos pesquisadores a sugerir os possíveis ambientes tectônicos de formação e a interpretar as condições nas quais as diferentes unidades de rochas metamórficas têm sido submetidas. Assim, os resultados aqui apresentados, juntamente com o esquema evolutivo da geologia, são uma primeira aproximação na busca de um modelo que integre a tectônica e o metamorfismo, com o intuito de resolver o problema do metamorfismo na Cordilheira Central dos Andes do Norte na Colômbia.

Pelas características petrográficas e da química mineral, pode-se determinar que os protólitos das diferentes unidades estudadas apresentam variações significativas quanto aos processos metamórficos que os afetaram.

Quanto aos Anfibólio Xistos de Caldas, as rochas originais devem corresponder a uma seqüência vulcanossedimentar constituída predominantemente por derrames de rochas básicas, mas de modo geral seriam seqüências de rochas básicas, que resultaram nos anfibólio xistos, com intercalações de camadas pouco espessas de sedimentos pelíticos, que geraram ao metamorfismo em grau médio biotita xistos com granada e estaurolita.

Os Xistos de Ancón representam o produto do metamorfismo em grau predominantemente médio de sedimentos pelíticos com variações consideráveis no conteúdo de matéria orgânica, resultando em diferentes xistos grafitosos. Incluem ainda leitos mais enriquecidos em alumina, nos quais os polimorfos de $\mathrm{Al}_{2} \mathrm{SiO}_{5}$ são mais freqüentes.

Ambos os conjuntos poderiam ter sido formados em um ambiente oceânico relativamente distal e sob condições predominantemente redutoras, posteriormente incorporados ao continente pelo desenvolvimento de uma zona de subducção.

$\mathrm{Na}$ região de El Retiro os protólitos são semelhantes aos que deram origem às rochas de Caldas, mas com variações significativas, especialmente pela presença de pequenas camadas de arenitos argilosos e sedimentos pelíticos intercalados nos derrames de basalto, que deram origem aos quartzitos intercalados e aos sericita xistos ao metamorfismo, indicando um ambiente mais proximal. A presença de abundantes diques de diabásio, que por vezes predominam em alguns afloramentos, e as idades dos migmatitos sugerem que, pelo menos em parte, eles possam representar o 
embasamento continental da área. Entretanto, parte deles pode corresponder a sedimentos impuros, de margem continental, metamorfisados em alto grau. metamorfismo nesta área foi mais intenso, resultando na formação de granulitos em porções da crosta nas quais a pressão parcial de $\mathrm{H}_{2} \mathrm{O}$ foi relativamente baixa, e de migmatitos, especialmente a partir das rochas de composição quartzo-feldspáticas, e em porções onde a pressão de $\mathrm{H}_{2} \mathrm{O}$ foi maior. Este metamorfismo foi acompanhado por intensa deformação, o que pode ter, nos seus eventos finais, justaposto blocos com granulitos e migmatitos. Com a deformação mais tardia houve intensa interação fluidorocha, assim como pontos restritos de calor causados por intrusões de rochas ígneas, responsáveis por variações na granulação dos minerais e, sobretudo pelo forte reequilíbrio retrometamórfico observado principalmente ao longo dos planos de cisalhamento, responsáveis pela canalização dos fluidos. É possível interpretar ainda que estas rochas foram afetadas por alterações metassomáticas de potássio, com cristalização de biotita, e hidrotermais, com intensa formação de veios e vênulas de quartzo, sericitização e vênulas de clinozoisita-epidoto.

As condições de metamorfismo obtidas nos diferentes litotipos são próximas, pois os Anfibólio Xistos de Caldas e a maioria das rochas de El Retiro encontram-se na fácies anfibolito, com exceção das rochas que alcançaram as fácies granulito.

A geotermobarometria das rochas de Ancón sugerem um aumento do grau metamórfico de sul para norte, pois as rochas que estão mais próximas aos Anfibólio Xistos de Caldas (sul) apresentam granada e estaurolita em paragênese, passando por xistos com granada sem estaurolita até chegar às proximidades do município de Sabaneta (norte), no qual as rochas apresentam sillimanita e biotita em paragênese. Cianita é descrita por Restrepo (1986) nesta região, indicando que as rochas foram metamorfisadas desde a zona da estaurolita até a zona da sillimanita. A presença de andalusita, na maioria das vezes da variedade chiastolita, parece ser indicativa da intrusão de granitos durante a exumação, resultando em um reaquecimento em temperaturas compatíveis com as fácies anfibolito e xisto verde, em regime de pressão mais baixa. Se forem consideradas as rochas presentes mais ao norte (Boquerón) como parte desta unidade, a unidade poderia então gradar para a fácies xisto verde, apesar da falta de minerais diagnósticos para definir a zona. Alternativamente, o conjunto de rochas aflorantes na região de Boquerón, poderiam constituir outra unidade de rochas metamórficas, sem ligação com os Xistos de Ancón. 
Os dados geocronológicos obtidos da área de estudo, além de serem muito dispersos, não esclarecem os eventos metamórficos, e são muito controversos, pois muitos deles são datações radiométricas pelo método Rb-Sr convencional, os quais dependem das razões iniciais de Sr, assumidas para a obtenção da idade, e somente as isócronas Rb-Sr poderiam ser usadas, mesmo assim com cautela. Além disso, vários dados disponíveis pelo método $\mathrm{K}-\mathrm{Ar}$ indicariam somente as idades de resfriamento do último evento térmico ao qual foram submetidas as rochas da área.

A maioria desses dados foi apresentada em Restrepo et al. (1991) e mostrados na Tabela 6, mas os dados importantes são ressaltados na tabela. Mesmo que o dado dos Anfibólio Xistos de Caldas não tenha sido obtido por isócrona Rb-Sr, a estratigrafia em relação aos Xistos de Ancón e sua situação como encaixante do Gnaisse de La Miel, parece ser o mais importante para as interpretações tectônicas feitas a partir dos dados geocronológicos disponíveis, assim como as trajetórias P-T obtidas nas distintas unidades.

Somente nos últimos anos tem sido obtido dados mais representativos pelos métodos Ar-Ar e Sm-Nd (i.e. Vinasco, 2001; Ordóñez, 1997; 2001), mas alguns deles também estão sendo reavaliados, objetivando uma melhor compreensão de seu significado.

A presença de cianita nos biotita xistos intercalados nos Anfibólio Xistos de Caldas (Restrepo, 1986), assim como a ausência de falhas entre os Xistos de Ancón, os Anfibólio Xistos de Caldas e os Anfibolitos, Migmatitos e Granulitos de El Retiro (Montes \& Restrepo, 2003), sugerem que as unidades podem ter uma história comum, cujo registro é observável nas diferentes trajetórias obtidas para cada conjunto. Esta história comum poderia ser considerada como uma etapa posterior à formação das rochas de Caldas-Ancón e El Retiro. As temperaturas mais altas são indicadas pela presença de sillimanita no município de Sabaneta, mas estas também podem ser resultados de focos de calor, possivelmente provenientes de corpos intrusivos, que só se manifestam como diques graníticos nesta zona, ou podem ser devidas ao aumento regional do grau de metamorfismo, com as rochas da zona da sillimanita situadas já nas proximidades da zona de fusão parcial, registrada pela presença dos mobilizados graníticos. Na área de El Retiro, as condições que deram origem às mudanças bastante amplas nas pressões e uma queda relativamente restrita na temperatura podem ter relação com uma descompressão rápida que gerou a fusão parcial dos metapelitos e mantiveram as metabásicas de Caldas aquecidas, registrando novas 
fases de cristalização da granada ao redor da granada pré-existente. Esta situação concorda com o aumento da pressão e o aumento suave na temperatura, resultando em pequena variação observada na trajetória metamórfica definida pelos Anfibólio Xistos de Caldas.

Associado a todos estes processos de aumento de temperatura concomitantemente à deformação, sua relação com os corpos intrusivos, assim como, a fusão parcial registrada nos migmatitos, estão os minerais hidrotermal encontrados nos anfibólio xistos, formados nos eventos finais, durante o cisalhamento.

O evento térmico que provocou a fusão parcial registrada nos migmatitos de $\mathrm{El}$ Retiro é evidenciado nos dados Ar-Ar (Vinasco et al., 2001) e Sm-Nd (Ordóñez, 2001), assim como por uma isócrona Rb-Sr em rocha total obtida nos Xistos de Ancón (Restrepo et al., 1991). Estes eventos relacionam-se com o desenvolvimento do cisalhamento regional, registrado nas amostras dos Anfibólio Xistos de Caldas e em algumas rochas da área de El Retiro, também indicado pelos dados geocronológicos de rochas deformadas associadas à falha Romeral (Vinasco, 2001). Este cisalhamento permitiu que uma grande quantidade de fluidos metamórficos percolassem as rochas, redistribuindo os elementos químicos, resultando na formação de novos minerais.

Segundo a geotermobarometria, os Anfibólio Xistos de Caldas, descrevem uma trajetória de aumento de pressão em um campo relativamente estreito de aumento da temperatura, mas sempre dentro da fácies anfibolito, a qual é compatível com a evolução em uma zona de subducção, onde teria havido o empilhamento tectônico de placas aquecidas, em possíveis zonas de empurrão, seguida pela exumação durante 0 início do resfriamento. A trajetória metamórfica seria, neste contexto, a do bloco cavalgado e, apesar de incompleta, sugere uma evolução P-T-t de sentido anti-horário (Figura 42). 
Tabela 6. Datações radiométricas obtidas nas diferentes unidades da área de estudo. Os nomes das unidades estão abreviados, sendo Anfibólio Xistos de Caldas (Caldas), Xistos de Ancón (Ancón), Gnaisse de La Miel (La Miel) e Anfibolitos, Migmatitos e Granulitos de El Retiro (El Retiro). Isócrona (I). Idade Modelo (I.M.).

\begin{tabular}{|c|c|c|c|c|}
\hline Unidade (abreviada) & Método & Material & Idade (Ma) & Referência \\
\hline Caldas & $\mathrm{K}-\mathrm{Ar}$ & Rocha total & $254 \pm 8$ & Restrepo et al. (1991) \\
\hline Caldas & $\mathrm{K}-\mathrm{Ar}$ & Anfibólio & $264 \pm 27$ & Restrepo et al., (1991) \\
\hline Caldas & $\mathrm{K}-\mathrm{Ar}$ & Rocha total & $306 \pm 15$ & Restrepo et al., (1991) \\
\hline Caldas & $\mathrm{K}-\mathrm{Ar}$ & Anfibólio & $319 \pm 48$ & Restrepo et al., (1991) \\
\hline Caldas & $\mathrm{K}-\mathrm{Ar}$ & Anfibólio & $324 \pm 16$ & Restrepo et al., 1991. \\
\hline Caldas & Rb-Sr & Rocha total & 381 & Restrepo et al. (1991) \\
\hline Caldas & $\mathrm{K}-\mathrm{Ar}$ & Anfibólio & $1670 \pm 500$ & Restrepo \& Toussaint (1978) \\
\hline Ancón & $\mathrm{K}-\mathrm{Ar}$ & Rocha total & $160 \pm 11$ & Restrepo et al. (1991) \\
\hline Ancón & $\mathrm{K}-\mathrm{Ar}$ & Rocha total & $182 \pm 8$ & Restrepo et al. (1991) \\
\hline Ancón & Rb-Sr (I) & Rocha total & $226 \pm 4$ & Restrepo et al. (1991) \\
\hline Ancón & $\mathrm{Rb}-\mathrm{Sr}$ & Rocha total & 261 & Restrepo et al. (1991) \\
\hline Ancón & $\mathrm{Rb}-\mathrm{Sr}$ & Rocha total & 271 & Restrepo et al. (1991) \\
\hline Ancón & $\mathrm{Rb}-\mathrm{Sr}$ & Rocha total & 273 & Restrepo et al. (1991) \\
\hline Ancón & $\mathrm{Rb}-\mathrm{Sr}$ & Rocha total & 294 & Restrepo et al. (1991) \\
\hline Ancón & $\mathrm{Rb}-\mathrm{Sr}$ & Rocha total & 365 & Restrepo et al. (1991) \\
\hline Ancón & $\mathrm{Rb}-\mathrm{Sr}$ & Rocha total & 380 & Restrepo et al. (1991) \\
\hline Ancón & $\mathrm{Rb}-\mathrm{Sr}$ & Rocha total & 412 & Restrepo et al. (1991) \\
\hline Ancón & $\mathrm{Rb}-\mathrm{Sr}$ & Rocha total & 433 & Restrepo et al. (1991) \\
\hline Ancón & $\mathrm{Rb}-\mathrm{Sr}$ & Rocha total & 493 & Restrepo et al. (1991) \\
\hline Ancón & $\mathrm{Rb}-\mathrm{Sr}$ & Rocha total & 555 & Restrepo et al. (1991) \\
\hline Ancón & $\mathrm{Rb}-\mathrm{Sr}$ & Rocha total & 626 & Restrepo et al. (1991) \\
\hline Ancón & $\mathrm{Rb}-\mathrm{Sr}$ & Rocha total & 702 & Restrepo et al. (1991) \\
\hline La Miel & $\mathrm{Rb}-\mathrm{Sr}$ & Rocha total & 329 & Restrepo et al. (1991) \\
\hline La Miel & $\mathrm{K}-\mathrm{Ar}$ & Muscovita & $331 \pm 28$ & Restrepo et al. (1991) \\
\hline La Miel & $\mathrm{Rb}-\mathrm{Sr}$ & Rocha total & 340 & Restrepo et al. (1991) \\
\hline La Miel & $\mathrm{K}-\mathrm{Ar}$ & Muscovita & $343 \pm 12$ & Restrepo \& Toussaint (1978) \\
\hline La Miel & $\mathrm{Rb}-\mathrm{Sr}$ & Rocha total & 353 & Restrepo et al. (1991) \\
\hline La Miel & $\mathrm{Rb}-\mathrm{Sr}$ & Rocha total & 364 & Restrepo et al. (1991) \\
\hline La Miel & Rb-Sr (I) & Rocha total & $388 \pm 12$ & Restrepo et al. (1991) \\
\hline La Miel & $\mathrm{Rb}-\mathrm{Sr}$ & Rocha total & 434 & Restrepo et al. (1991) \\
\hline La Miel & $\mathrm{Rb}-\mathrm{Sr}$ & Rocha total & 438 & Restrepo et al. (1991) \\
\hline La Miel & $\mathrm{Rb}-\mathrm{Sr}$ & Rocha total & 473 & Restrepo et al. (1991) \\
\hline La Miel & $\mathrm{Rb}-\mathrm{Sr}$ & Rocha total & 480 & Restrepo et al. (1991) \\
\hline La Miel & $\mathrm{Rb}-\mathrm{Sr}$ & Rocha total & 491 & Restrepo et al. (1991) \\
\hline La Miel & $\mathrm{Rb}-\mathrm{Sr}$ & Rocha total & 497 & Restrepo et al. (1991) \\
\hline La Miel & $\mathrm{Rb}-\mathrm{Sr}$ & Rocha total & 539 & Restrepo et al. (1991) \\
\hline La Miel & $\mathrm{Rb}-\mathrm{Sr}$ & Rocha total & 550 & Restrepo et al. (1991) \\
\hline La Miel & $\mathrm{Rb}-\mathrm{Sr}$ & Rocha total & $580 \pm 40$ & Toussaint (1978) \\
\hline La Miel & $\mathrm{Rb}-\mathrm{Sr}$ & Rocha total & 588 & Restrepo et al. (1991) \\
\hline La Miel & $\mathrm{Rb}-\mathrm{Sr}$ & Rocha total & 603 & Restrepo et al. (1991) \\
\hline La Miel & $\mathrm{Rb}-\mathrm{Sr}$ & Rocha total & 625 & Restrepo et al. (1991) \\
\hline La Miel & $\mathrm{Rb}-\mathrm{Sr}$ & Rocha total & 661 & Restrepo et al. (1991) \\
\hline La Miel & $\mathrm{Rb}-\mathrm{Sr}$ & Rocha total & 814 & Restrepo et al. (1991) \\
\hline La Miel & $\mathrm{Rb}-\mathrm{Sr}$ & Rocha total & 901 & Restrepo et al. (1991) \\
\hline El Retiro & Sm-Nd & Grt-Rocha total & $226 \pm 10$ & Ordóñez (2001) \\
\hline El Retiro (anfibolito) & $\mathrm{Ar}-\mathrm{Ar}$ & Anfibólio & $231 \pm 1$ & Vinasco et al. (2001) \\
\hline El Retiro (migmatito) & $\mathrm{Rb}-\mathrm{Sr}$ & Rocha total & 238 & Restrepo et al. (1991) \\
\hline EI Retiro (granulito) & $\mathrm{K}-\mathrm{Ar}$ & Rocha total & $251 \pm 21$ & Restrepo et al. (1991) \\
\hline El Retiro (migmatito) & $\mathrm{Rb}-\mathrm{Sr}$ & Rocha total & 294 & Restrepo et al. (1991) \\
\hline El Retiro (migmatito) & $\mathrm{Rb}-\mathrm{Sr}$ & Rocha total & 427 & Restrepo et al. (1991) \\
\hline El Retiro (migmatito) & $\mathrm{Rb}-\mathrm{Sr}$ & Rocha total & 904 & Restrepo et al. (1991) \\
\hline El Retiro (migmatito) & $\mathrm{Rb}-\mathrm{Sr}$ & Rocha total & 1078 & Restrepo et al. (1991) \\
\hline El Retiro (granitóide) & $\mathrm{Sm}-\mathrm{Nd}$ & I.M. TDM & 1410 & Ordóñez (1997) \\
\hline
\end{tabular}




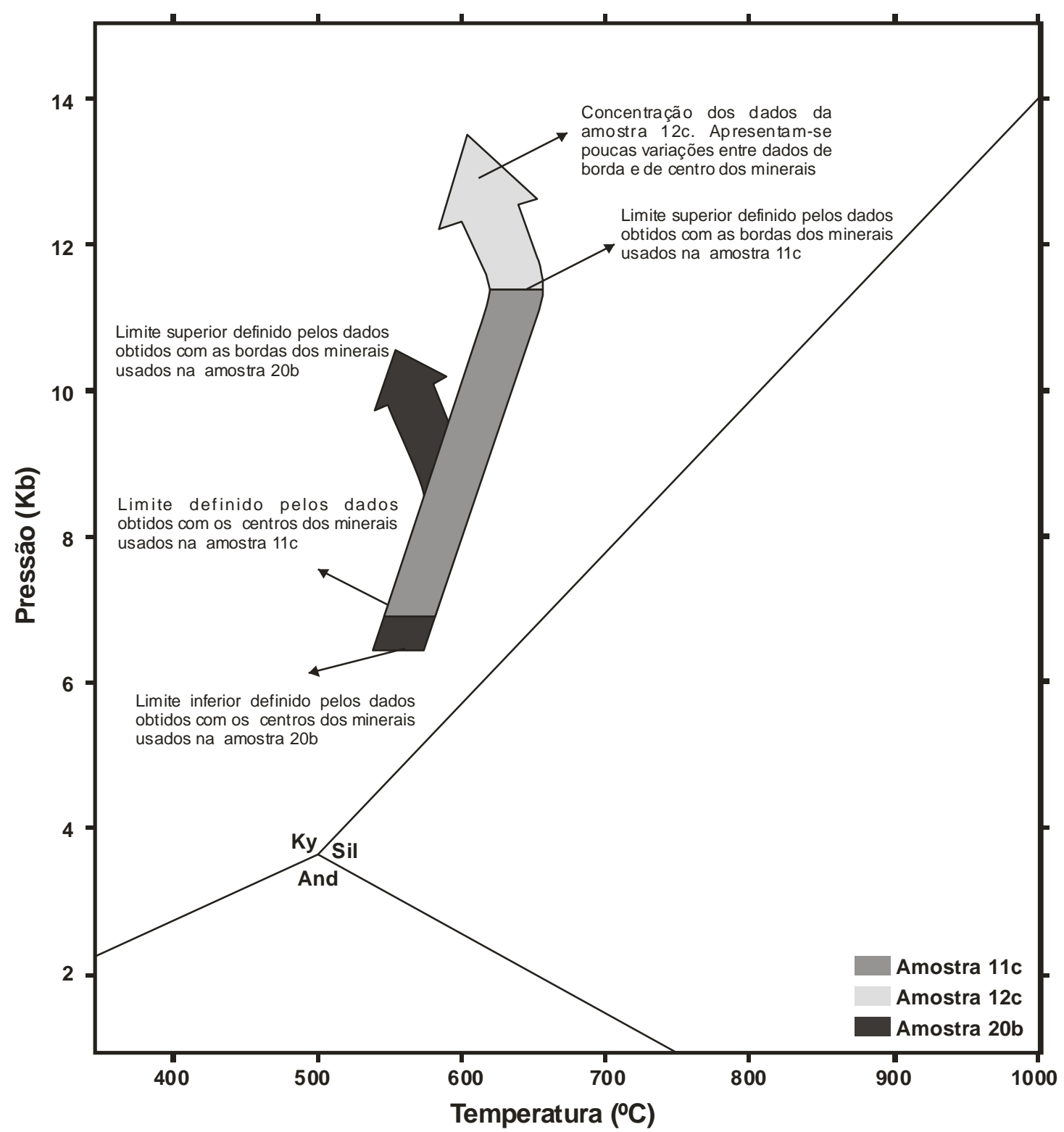

Figura 42. Trajetória em sentido anti-horária definida pelos Anfibólio Xistos de Caldas.

Os Xistos de Ancón exibem uma trajetória P-T-t de caráter anti-horário, com pico térmico na zona da sillimanita e voltando pela zona da cianita, segundo os dados petrográficos, e chegando quase até o ponto de origem (Figura 43). 


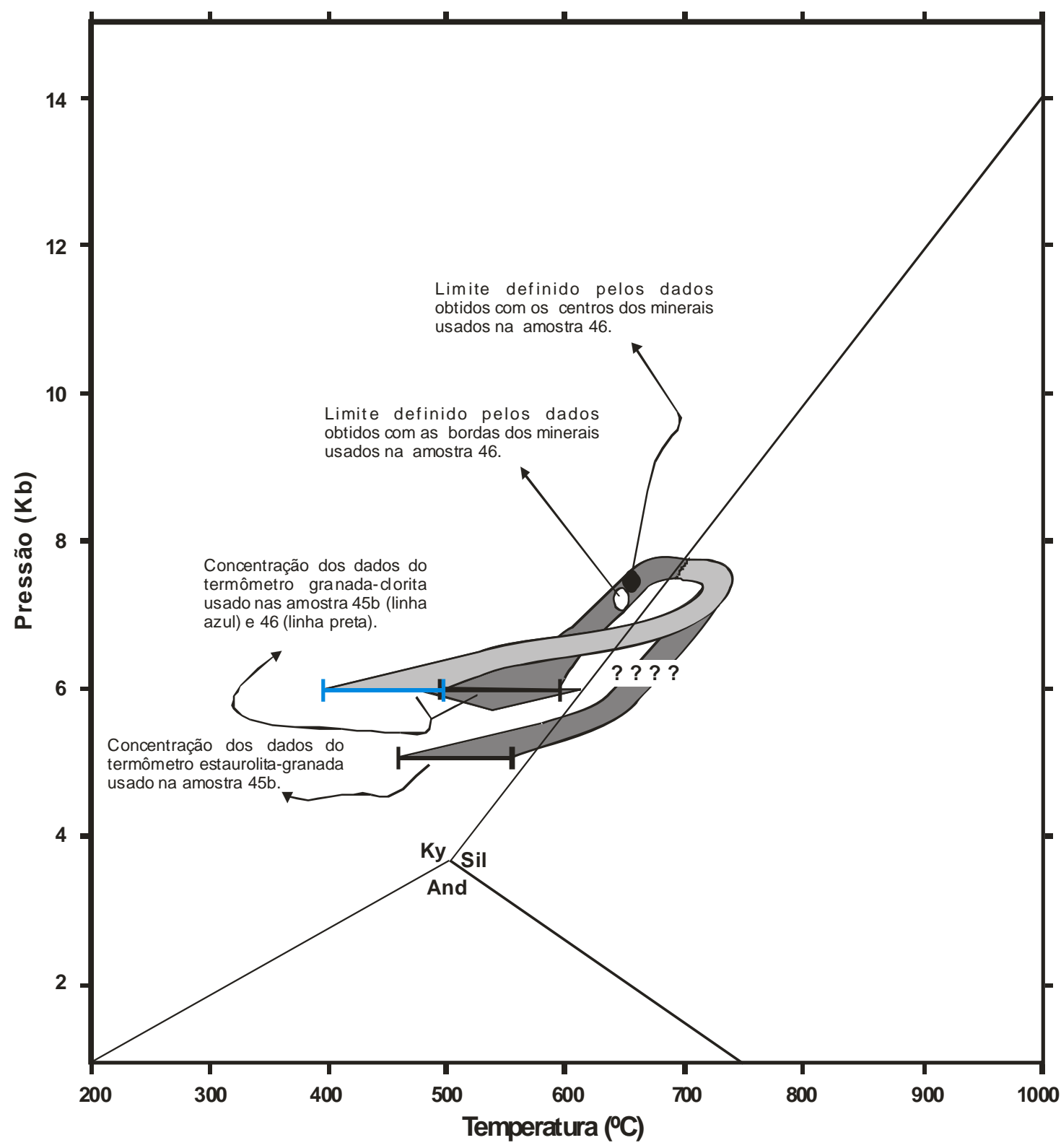

Figura 43. Trajetória em sentido anti-horária definida pelos Xistos de Ancón, onde a linha clara indica o início da trajetória obtida com o termômetro granada-clorita e a linha escura superior o fim desta trajetória. Já a linha escura inferior mostra o início da trajetória considerado o termômetro estaurolita-granada.

Mesmo que as trajetórias metamórficas anti-horárias dos Anfibólio Xistos de Caldas e dos Xistos de Ancón não se superponham no campo P-T, as relações estratigráficas permitem inferir que o evento metamórfico que as afetou foi o mesmo. Assim, as diferenças podem ser explicadas pelo posicionamento em relação à zona de subducção e de sutura, mais próximas para as rochas de Caldas, e mais distais e internas para as rochas de Ancón, com exumação mais lenta, que possibilitou um maior aquecimento durante a recuperação das isotermas, bem como um melhor registro da pressão mais baixa, quando as rochas já estavam mais aquecidas. 
Para o migmatito de El Retiro, com os dados obtidos, observa-se uma forte descompressão com pouca variação na temperatura, situação esta que é compatível com regimes de fusão parcial e possível colocação de um corpo granítico raso (Figura 44). Os dados obtidos com o geotermômetro cloritóide-clorita somente podem ser explicados, segundo o esquema evolutivo proposto, pela incorporação tectônica de lascas de sericita xisto com cloritóide da fácies xisto verde dentro das rochas de alto grau, ou por um completo reequilíbrio de metassedimentos pelíticos e/ou de milonitos fortemente lixiviados hidrotermalmente, durante o desenvolvimento das zonas de cisalhamento.

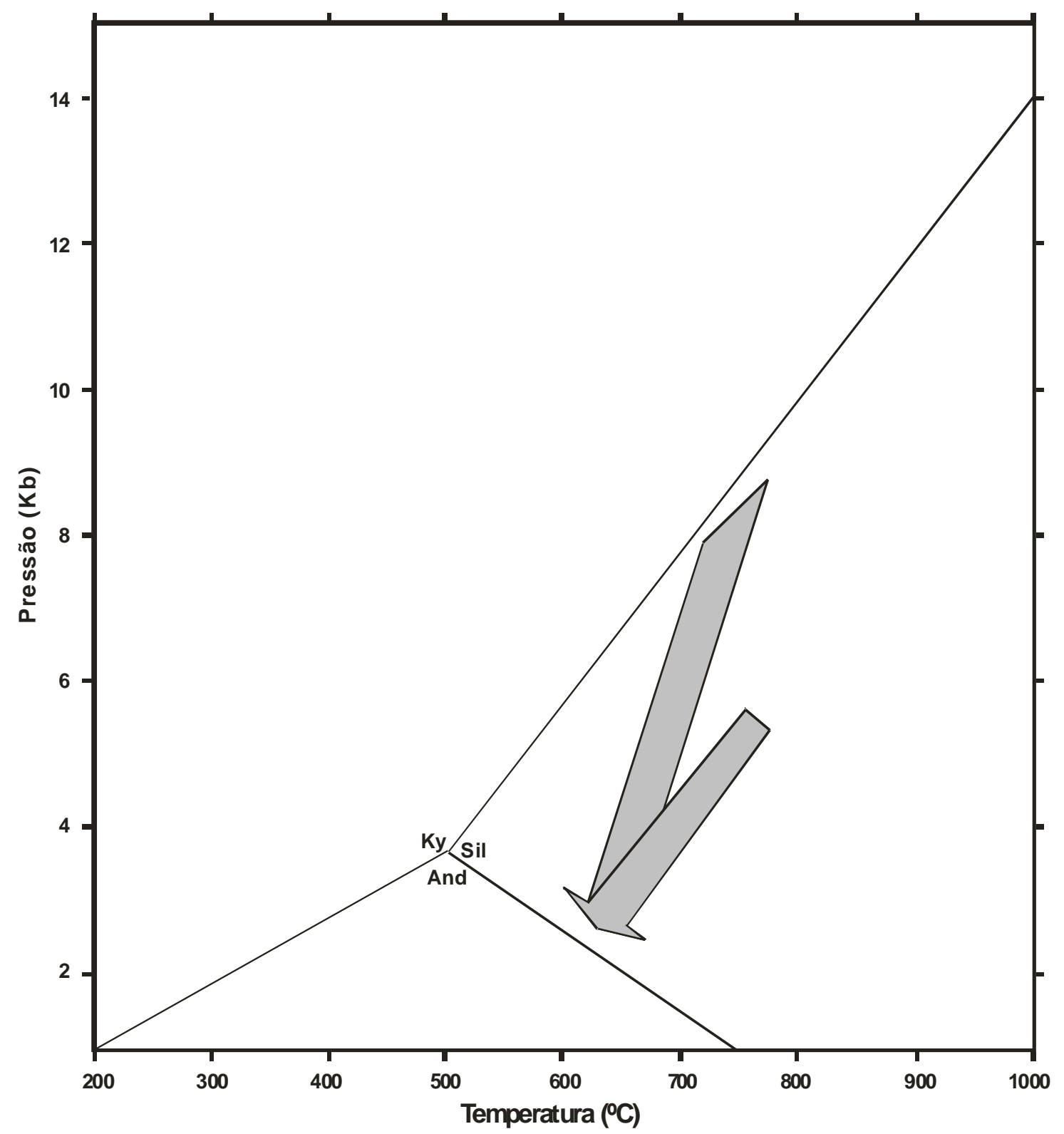

Figura 44. Trajetória metamórfica definida pela amostra de melanossoma do migmatito de El Retiro. 
A comparação de todas as trajetórias P-T-t obtidas para as rochas da área de trabalho, pode ser mais bem visualizada na Figura 45.

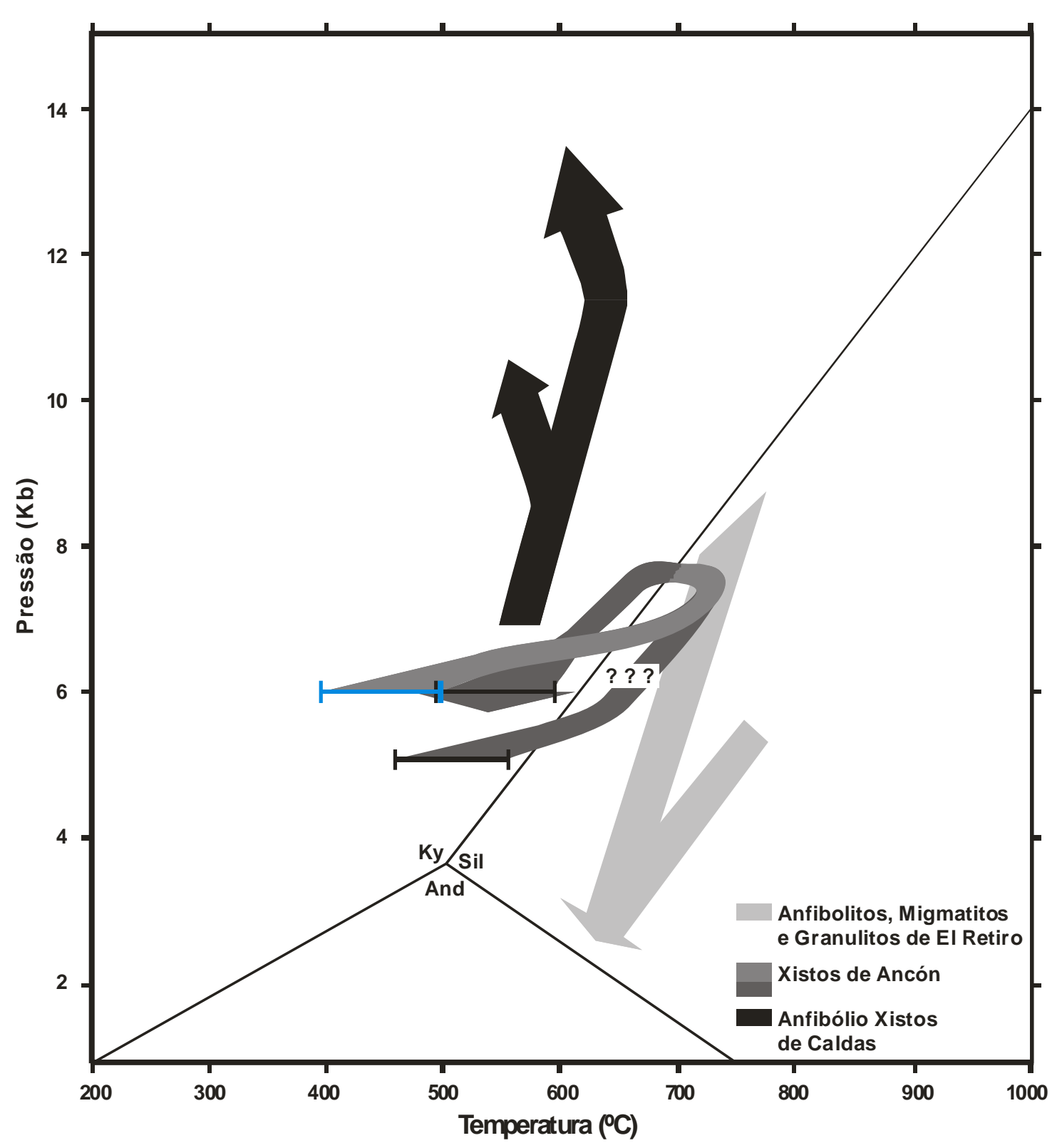

Figura 45. Comparação de todas as trajetórias obtidas para as rochas da área de trabalho.

Este conjunto de processos pode sugerir um rifteamento incipiente, possivelmente em um regime transpressivo-transtensivo, no qual são comuns pontos de calor restritos, assim como, diferentes razões fluido-rocha e deformação associada.

Este modelo sugere que os Anfibólio Xistos de Caldas e os Xistos de Ancón representem uma parte da crosta exumada, logo depois de um processo de subducção 
antigo, o qual poderia ser o resultado de uma convergência de baixo ângulo, fazendo com que zonas de concentração do cisalhamento fossem a resposta deste processo.

Neste contexto, o Gnaisse de La Miel representa um granito sin-colisional, como é indicado pelos dados geoquímicos (Vinasco, 2003 -comunicação oral; Bustamante \& Cardona, 2003), que começa a fazer parte da evolução desta região logo depois que os Anfibólio Xistos de Caldas foram formados, ou até mesmo concomitante com eles, uma vez que o metamorfismo que deu origem aos xistos foi o mesmo que gerou o gnaisse. Este processo de rifteamento é bem registrado nos Xistos de Ancón e nas rochas de El Retiro, possivelmente pela susceptibilidade que têm os metapelitos para registrar este tipo de aquecimentos, diferente da do Gnaisse de La Miel e da dos Anfibólio Xistos de Caldas.

Fica evidente que a geotermobarometria aporta novos rumos para 0 entendimento do problema do metamorfismo na Cordilheira Central dos Andes da Colômbia, mas é um primeiro passo que precisa ser continuado, mas que deverá ser acompanhado por estudos mais detalhados de geologia estrutural, geocronologia e granitogênese, visando inserir esta porção da cordilheira dentro do contexto tectonometamórfico dos Andes do Norte. 


\section{REFERÊNCIAS BIBLIOGRÁFICAS}

ARANOVICH, L. YA., LAVRENT'EVA, I.V., KOSYAKOVA, N.A., 1988. Calibration of the biotite-garnet and biotite-orthopyroxene geothermometers corrected for the variable Al level in biotite. Geochemistry International, 25(12): 50-59.

ARDILA, R. 1986. Petrografía de las rocas metamórficas de El Retiro - Antioquia. Tesis de grado. Universidad Nacional. Medellín. 178 p.

BERMAN, R.G., 1988. Internally consistent thermodynamic data for minerals in the system $\mathrm{Na}_{2} \mathrm{O}-\mathrm{K}_{2} \mathrm{O}-$ $\mathrm{CaO}-\mathrm{MgO}-\mathrm{FeO}-\mathrm{Fe}_{2} \mathrm{O}_{3}-\mathrm{Al}_{2} \mathrm{O}_{3}-\mathrm{SiO}_{2}-\mathrm{TiO}_{2}-\mathrm{H}_{2} \mathrm{O}-\mathrm{CO}_{2}$. Journal of Petrology, 29: 445-522.

BERMAN, R.G., 1991. Thermobarometry using multi-equilibrium calculations: a new technique, with petrological applications. Canadian Mineralogist, 29: 833-855.

BOTERO, G. 1963. Contribución al conocimiento de la geología de la zona central de Antioquia. Anales Facultad de Minas. Universidad Nacional. Medellín, 57:1-101.

BUSTAMANTE, A., CARDONA, A., 2003 (em preparação). Cartografía, petrografía y geoquímica del Neis de La Miel, Antioquia.

DEER, W.A., HOWIE, R.A., ZUSSMAN, J., 1992. An introduction to the rock-forming minerals. Longman Scientific \& Technical. USA. 696 p.

DICKENSON, M.P., HEWITT, D.A., 1986. A garnet-chlorite geothermometer. Geological Society of America Bulletin, Abstracts with Programs. p 586.

DICKINSON, W.R., LAWTON, T.F., 2001. Carboniferous to Cretaceous assembly and fragmentation of Mexico. Geological Society of America Bulletin, 113: 1142-1160.

ECHEVERRÍA, L., 1973. Zonación de las rocas metamórficas del Valle de Aburrá y sus alrededores. Tesis de grado. Universidad Nacional. Medellín, 124 p.

ESCOBAR, A., MAYA, M. 1985. Estudio de las rocas metamórficas entre el Ancón Sur y la quebrada La Miel, Caldas-Antioquia. Tesis de grado. Universidad Nacional, Medellín, 160 p.

ESQUIVEL, J., FLOREZ, D., NUÑEZ, A., 1981. Anfibolitas granatíferas, esquistos anfibólicos y rocas máficas - ultramáficas al Este de Buga - Palmira, Valle, Colombia. Resúmenes, III Congreso Colombiano de Geología, Medellín, 40-41.

FEININGER, T., BARRERO, D., CASTRO, N., 1972. Geología de los departamentos de Antioquia y Caldas (Sub zona IIB): Boletín Geológico INGEOMINAS 20(2), 173 p.

FORERO-SUÁREZ, A., 1991. Distribución de las rocas del Devónico en los Andes Colombianos. En: Suarez, R(ed). Trabajos presentados en la reunión del Proyecto 193, Siluro-Devonian of Latin America. La Paz, Bolivia. Revista Técnica de Yacimientos Petrolíferos Fiscales Bolivianos, 12: 101111.

GONZÁLEZ, H., 1980. Geología de las planchas 167 (Sonsón) y 187 (Salamina). Boletín Geológico INGEOMINAS, 23(1), $174 \mathrm{p}$.

GONZÁLEZ, H., 1999. Geologia del departamento de Antioquia, Escala 1:400.000. INGEOMINAS.

GROTJOHANN, H., McCOURT, W., 1981. Resultados de los trabajos corrientes en la cartografía geológica regional del departamento del Valle (Cordillera Central). Resúmenes, III Congreso Colombiano de Geología, Medellín, 3-4.

HIBBARD, 1995. Petrography to petrogenesis. Prentice Hall. USA. 335p. 
JAILLARD, E., SOLER, P., CARLIER, G., MOURIER, T., 1990. Geodynamic evolution of the Northern and Central Andes during early and middle Mesozoic times: a Tethyan model. Journal of the Geological Society of London, 147: 1009-1022.

KERR, A.C., ASPDEN, J.A., TARNEY, J., PILATASIG, L.F., 2002. The nature and provenance of accreted oceanic terranes in western Ecuador; geochemical and tectonic constraints. Journal of Geological Society of London, 159: 577-594.

KRETZ, R., 1983. Symbols for rock-forming minerals. American Mineralogist, 68: 277-279.

LEAKE, B.E., WOOLLEY, A.R., ARPS, C.E.S., BIRCH, W.D., GILBERT, M.C., GRICE, J.D., HAWTHORNE, F.C., KATO, A., KISCH, H.J., KRIVOVICHEV, V.G., LINTHOUT, K., LAIRD, J., MANDARINO, J.A., MARESCH, W.V., NICKEL, E.H., ROCK, N.M.S., SCHUMACHER, J.C., SMITH, D.C., STEPHENSON, N.C.N., UNGARETTI, L., WHITTAKER, E.J.W., YOUZHI, G., 1997. Nomenclature of amphiboles: report of the subcommittee on amphiboles of the International Mineralogical Association, commission on new minerals and mineral names. Canadian Mineralogist, 35: 219-246.

MAYA, M., 2001. Distribución, facies y edad de las rocas metamórficas en Colombia. Informe 1-2426. INGEOMINAS, $57 \mathrm{p}$.

MAYA M., GONZÁLEZ, H., 1995. Unidades litodémicas en la Cordillera Central de Colombia. Boletín Geológico INGEOMINAS, 35: 43-57.

McCOURT, W.J., 1984. The geology of the central Cordillera in the departments of Valle del Cauca, Quindio and NW Tolima (Sheets 243, 261, 262, 280 Y 300). INGEOMINAS - Misión Británica, Informe interno.

McCOURT, W.J., FEININGER, T., 1984. High pressure metamorphic rocks in the Central Cordillera of Colombia. British Geological Survey Reprint Series, 84(21): 28-35.

MEGARD, F., 1987. Cordilleran Andes and Marginal Andes: A review of andean geology North of the Arica elbow (18 $)$. American Geophysical Union Monography, 18: 71-95.

MIYASHIRO, A., 1961. Evolution of metamorphic belts. Journal of Petrology, 2: 277-311.

MONTES, L.F., RESTREPO, J.J., 2003. Relación entre las metamorfitas de alto y bajo grado en el sur del Valle de Aburrá, Antioquia. Resúmenes, IX Congreso Colombiano de Geología, Medellín, p 60.

MOSQUERA, D., 1978. Geología del Cuadrángulo K-8. Informe interno. INGEOMINAS, 1-78.

MOSQUERA, D., NUÑEZ, A., VESGA, J., 1982. Mapa geológico de la Plancha 244 -lbagué-, Escala 1:100.000. INGEOMINAS.

MURCIA, A, CEPEDA, H., 1991a. Mapa geológico de la Plancha 410 -La Unión-, Escala 1:100.000. INGEOMINAS.

MURCIA, A, CEPEDA, H., 1991b. Mapa geológico de la Plancha 429 -Pasto-, Escala 1:100.000. INGEOMINAS.

NELSON, W., 1957. Contribution to the Geology of the Central and Western Cordillera of Colombia in the Sector Between Ibague and Cali. Leidse Geologische Mededelingen, 22: 1-75.

NESSE, W.D., 1991. Introduction to optical mineralogy. $2^{\text {nd }}$ edition. Oxford University Press. USA. 335 p.

NOBLE, S.R., ASPDEN, J.A., JEMIELITA, R., 1997. Northern Andes Crustal Evolution: New U-Pb geochronological constraints from Ecuador. Geological Society of America Bulletin, 109: 789-798. 
NOREÑA, J.A., PATIÑO, J. de J., 1984. Estudio de las rocas metamórficas en la parte sur del municipio de Caldas, Antioquia. Tesis de grado. Universidad Nacional. Medellín, 154 p.

ORDÓÑEZ, O., 1997. O Pré-Cambriano na parte norte da Cordilheira Central dos Andes Colombianos. Dissertação de mestrado. Universidade de Brasília, Brasília, DF., 99 f.

ORDÓÑEZ, O., 2001. Caraterização isotópica Rb-Sr e Sm-Nd dos principais eventos magmáticos nos Andes colombianos. Tese de doutorado. Universidade de Brasília, Brasília, DF., 197 f.

ORDÓÑEZ, O., PIMENTEL, M.M., CORREA, A.M., MARTENS, U., RESTREPO, J.J. 2000. Edad Sm/Nd del metamorfismo de alto grado de El Retiro (Antioquia). Resúmenes Coloquio sobre el Precámbrico. INGEOMINAS. Bogotá.

ORREGO, A., CEPEDA, H., RODRíGUEZ, G., 1980. Esquistos glaucofánicos en el área de Jambaló Cauca (Colombia). Nota Preliminar. Geología Norandina, 1: 5-10.

ORREGO, A., LEON, L.,PADILLA, L, ACEVEDO, A.P., MARULANDA, N., 1993. Mapa geológico de la Plancha 364 - Timbío; Escala 1:100.000. INGEOMINAS.

ORREGO, A., PARÍS, G., 1991. Mapa geológico del Cuadrángulo N-6 Popayán; Informe interno. Escala 1:100.000, INGEOMINAS.

PASSCHIER, C.W., TROUW, R.A.J., 1996. Microtectonics. Springer. Germany. 289 p.

PERCHUK, L.L., 1991. Derivation of a thermodynamically consistent set of geothermometers and geobarometers for metamorphic and magmatic rocks. In: Perchuk, L.L. (Ed.) Progress in Metamorphic and Magmatic Petrology. Cambridge University Press, Cambridge, p. 93 - 111.

POWELL, R. \& HOLLAND. T.J.B., 1985. An internally consistent thermodynamic dataset with uncertainties and correlations: I Methods and worked example. Journal of Metamorphic Geology, 1: 327-342.

POWELL, R. \& HOLLAND. T.J.B., 1988. An internally consistent thermodynamic dataset with uncertainties and correlations: III Applications to geobarometry, worked examples and a computer program. Journal of Metamorphic Geology, 6: 173-204.

RAMOS, V., 1999. Plate tectonic setting of the Andean Cordillera. Episodes, 22: 183-190.

RAMOS, V., ALEMAN, A., 2000. Tectonic evolution of the Andes. In: Cordani, U.G., Milani, E.J., Filho, A.T., Campos, D.A. (eds) Tectonic evolution of South America. $31^{\text {st }}$ International Geological Congress, Rio de Janeiro, 635-685.

RESTREPO, J.J., 1986. Metamorfismo en el sector norte de la Cordillera Central de Colombia. Trabajo promoción a profesor titular. Universidad Nacional, Medellín, 276 p.

RESTREPO, J.J., TOUSSAINT, J.F., 1975. Edades radiométricas de algunas rocas de Antioquia, Colombia. Publicación Especial de Geología, Universidad Nacional Medellín 6, 1-24.

RESTREPO, J.J., TOUSSAINT, J.F., 1978. Ocurrencia de precámbrico en las cercanías de Medellín, Cordillera Central de Colombia. Publicación Especial de Geología, Universidad Nacional Medellín 12, $1-11$.

RESTREPO, J.J., TOUSSAINT, J.F., 1982. Metamorfismos superpuestos en la Cordillera Central de Colombia: V Congreso Latinoamericano de Geología, Argentina. Actas 3, 505-512.

RESTREPO, J.J., TOUSSAINT, J.F., 1984. Unidades Litológicas de los Alrededores de Medellín: Primera Conferencia de Riesgos Geológicos del Valle de Aburrá, Medellín, 25 p. 
RESTREPO, J.J., TOUSSAINT, J.F., 1988. Terranes and continental accretion in the Colombian Andes, Episodes, 11(3): 189-193.

RESTREPO, J.J., TOUSSAINT, J.F., GONZÁLEZ, H., LINARES, E., 1978. Datación de metasedimentos del Grupo Ayura - Montebello. Publicación Especial Geología, Facultad de Ciencias, Medellín, 10: 15 .

RESTREPO, J.J., TOUSSAINT, J.F., GONZÁLEZ, H., CORDANI, U., KAWASHITA, K., LINARES, E., PARILA, C., 1991. Precisiones geocronológicas sobre el occidente colombiano: Simposio de magmatismo Andino y su Marco Tectónico, Manizales, Memorias, Tomo I, 1 - 22.

SALDARRIAGA, S.M., SEPÚLVEDA, R.D. 1980. Metamorfismo de las Rocas del Oriente del Municipio de Caldas, Antioquia. Tesis de grado. Universidad Nacional. Medellín, 119 p.

SENGUPTA, P.; DASGUPTA, S.; BHATTACHARYA, P.K., MUKHERJEEE, M., 1990. An orthopyroxenebiotite geothermometer and its applications in crustal granulites and mantle-derived rocks. Journal of Metamorphic Geology, 8(2): 191-197.

SPEAR, F.S., 1989. Petrologic determination of metamorphic pressure-temperature-time paths. In: Spear, F.S., Peacock, S.M., 1989. Metamorphic Pressure-temperature-time paths. Short Course in Geology, American Geophysical Union, Washington D.C., 1-55 p.

SPEAR, F.S., (1993): Metamorphic phase-equilibria and pressure-temperature-time paths. Mineralogical Society of America. USA. 799 p.

SPRY, A., 1969. Metamorphic textures. Pergamon Press. Great Britain. 350 p.

TOUSSAINT, J.F., 1978. Grandes rasgos geológicos en la parte septentrional del occidente colombiano. Boletín Ciencias de la Tierra Universidad Nacional, 3: 1-231.

TOUSSAINT, J.F., 1993. Evolución Geológica de Colombia, Precámbrico-Paleozoico. Universidad Nacional de Colombia. Medellín, 229 p.

TOUSSAINT, J.F., 1996. Evolución Geológica de Colombia, Cretácico. Universidad Nacional de Colombia. Medellín, 142 p.

TOUSSAINT, J.F., RESTREPO, J.J., 1978. Edad cretácea de una anfibolita granatífera de Pijao, Quindío. Publicación Especial Geológica, Universidad Nacional Medellín, 17, 1-2.

TRÖGER, W.E., 1979. Optical determination of rock-forming minerals. Part I determinative tables. Scheweizerbart'sche Verlagsbuschhandlung. Deutchland. $188 \mathrm{p}$.

VIDAL, O., GOFFÉ, B., BOUSQUET, R., PARRA, T., 1999. Calibration and testing of and empirical chloritoid-chlorite $\mathrm{Mg}-\mathrm{Fe}$ exchange thermometer and thermodinamic data for daphnite. Journal of Metamorphic Geology, 17: 25-39.

VINASCO, C., 2001. A utilização da metodologia ${ }^{40} \mathrm{Ar}^{39} \mathrm{Ar}$ para o estudo de reativações tectônicas em zonas de cisalhamento. Paradigma - o falhamento de Romeral nos Andes Centrais da Colômbia. Dissertação de mestrado. Universidade de São Paulo, São Paulo, SP. 112 p.

VINASCO, C., CORDANI, U., VASCONCELOS, P., 2001. ${ }^{40} \mathrm{Ar} /{ }^{39} \mathrm{Ar}$ dates in the Central Cordillera of Colombia: Evidence for na important regional tectonomagmatic event in the Upper Triassic. Abstracts III South American Symposium on isotope geology, Chile, Revista Comunicaciones. $171 \mathrm{f}$. 


\section{ANEXOS}

Tabela de minerais presentes nas diferentes amostras de migmatitos.

Tabelas de análises químicas.

Tabelas mostrando as associações e respectivas análises usadas nos cálculos termobarométricos realizados utilizando-se o software TWQ. 


\section{ANEXO I}

\section{Tabela de minerais presentes nas diferentes amostras de migmatitos.}


Tabela. Minerais presentes nas diferentes amostras de migmatitos.

\begin{tabular}{|c|c|c|c|c|c|c|c|c|c|c|c|c|c|c|c|c|c|}
\hline $\begin{array}{c}\text { Mineral } \\
\text { Amostra }\end{array}$ & Qtz & Bt & PI & Ms & Sil & Grt & Kfs & Mc & Src & Chl & $\mathrm{IIm}$ & Tur & Zrn & Mnz & $A p$ & Amp & Ep \\
\hline 10 & $\bullet$ & $\bullet$ & $\bullet$ & $\bullet$ & $\bullet$ & & & & $\bullet$ & & & $\bullet$ & $\bullet$ & & $\bullet$ & & \\
\hline 21 & $\bullet$ & $\bullet$ & $\bullet$ & $\bullet$ & & $\bullet$ & $\bullet$ & & $\bullet$ & & & $\bullet$ & & & & & \\
\hline $21 b$ & • & $\bullet$ & $\bullet$ & • & & & & & • & • & & $\bullet$ & & & & & \\
\hline $21 \mathrm{e}$ & & $\bullet$ & & $\bullet$ & & & & & • & $\bullet$ & $\bullet$ & & & & & & \\
\hline $21 f$ & $\bullet$ & $\bullet$ & $\bullet$ & $\bullet$ & $\bullet$ & $\bullet$ & & & • & • & & & & & & & \\
\hline 22 & $\bullet$ & • & $\bullet$ & • & $\bullet$ & $\bullet$ & & & & & • & & & & & & \\
\hline $22 b$ & $\bullet$ & • & • & • & $\bullet$ & $\bullet$ & & & • & & • & & & & & & \\
\hline $22 c$ & $\bullet$ & $\bullet$ & • & • & $\bullet$ & & & & & • & • & & & & & & \\
\hline $22 d$ & • & • & - & • & • & - & & & • & • & • & & & & & & \\
\hline 23 & $\bullet$ & $\bullet$ & & $\bullet$ & $\bullet$ & $\bullet$ & $\bullet$ & & $\bullet$ & & $\bullet$ & $\bullet$ & & & & & \\
\hline 25 & $\bullet$ & $\bullet$ & & • & & & & & - & - & & & & & & & \\
\hline $25 b$ & $\bullet$ & $\bullet$ & $\bullet$ & $\bullet$ & & & & & & $\bullet$ & $\bullet$ & $\bullet$ & & & & & \\
\hline 26 & $\bullet$ & $\bullet$ & $\bullet$ & $\bullet$ & $\bullet$ & & & & $\bullet$ & $\bullet$ & $\bullet$ & & & & & & \\
\hline $26 b *$ & $\bullet$ & $\bullet$ & $\bullet$ & & & & & & & & $\bullet$ & & & & & $\bullet$ & \\
\hline $26 c$ & $\bullet$ & $\bullet$ & $\bullet$ & & & $\bullet$ & & & & & $\bullet$ & & & & & & \\
\hline 53 & $\bullet$ & $\bullet$ & $\bullet$ & $\bullet$ & $\bullet$ & $\bullet$ & & $\bullet$ & $\bullet$ & $\bullet$ & & & & $\bullet$ & & & \\
\hline 54 & $\bullet$ & $\bullet$ & $\bullet$ & $\bullet$ & & & & & $\bullet$ & $\bullet$ & & & & & & & \\
\hline $54 b$ & • & & $\bullet$ & • & & & & & $\bullet$ & & • & & & & $\bullet$ & & \\
\hline $54 c$ & • & $\bullet$ & $\bullet$ & & & & $\bullet$ & & • & • & & & & & $\bullet$ & & $\bullet$ \\
\hline 54d & • & $\bullet$ & $\bullet$ & & $\bullet$ & & & & • & • & & & & & & & \\
\hline $54 e^{*}$ & • & & $\bullet$ & & & & & & & & • & & & & & • & \\
\hline 55 & • & $\bullet$ & & • & & & & & • & • & - & • & & & & & \\
\hline $55 b$ & $\bullet$ & & $\bullet$ & & & $\bullet$ & & & $\bullet$ & & & $\bullet$ & & & & $\bullet$ & $\bullet$ \\
\hline 63 & $\bullet$ & $\bullet$ & $\bullet$ & $\bullet$ & $\bullet$ & $\bullet$ & & & $\bullet$ & $\bullet$ & $\bullet$ & & $\bullet$ & & & 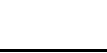 & \\
\hline
\end{tabular}




\section{ANEXO II}

Tabelas de análises químicas 
Tabela 1. Análises de anfibólio usados nos cálculos de geotermobarometria.

\begin{tabular}{|c|c|c|c|c|c|c|c|c|c|c|c|c|c|c|c|c|c|c|}
\hline Análise & 065 & 066 & 067 & 068 & 070 & 074 & 077 & 079 & 082 & 085 & 088 & 089 & 090 & 091 & 094 & 095 & 101 & 102 \\
\hline $\mathrm{SiO}_{2}$ & 42.25 & 41.42 & 44.97 & 41.12 & 41.17 & 44.97 & 41.17 & 47.86 & 40.08 & 46.34 & 40.03 & 48.58 & 39.88 & 45.28 & 49.28 & 48.27 & 40.51 & 39.69 \\
\hline $\mathrm{TiO}_{2}$ & 0.35 & 0.26 & 0.24 & 0.43 & 0.38 & 0.19 & 0.37 & 0.27 & 0.31 & 0.27 & 0.44 & 0.22 & 0.56 & 0.36 & 0.20 & 0.09 & 0.42 & 0.33 \\
\hline $\mathrm{Al}_{2} \mathrm{O}_{3}$ & 16.10 & 15.71 & 12.28 & 16.75 & 16.70 & 11.93 & 16.82 & 8.98 & 16.02 & 10.08 & 19.82 & 8.21 & 19.41 & 12.63 & 10.17 & 10.27 & 18.20 & 18.47 \\
\hline $\mathrm{FeO}$ & 14.59 & 15.19 & 13.77 & 17.28 & 17.82 & 17.04 & 17.74 & 17.61 & 18.41 & 18.40 & 15.71 & 17.16 & 15.40 & 15.14 & 16.39 & 16.06 & 17.13 & 17.08 \\
\hline MnO & 0.29 & 0.33 & 0.27 & 0.17 & 0.14 & 0.14 & 0.14 & 0.17 & 0.13 & 0.18 & 0.25 & 0.27 & 0.19 & 0.23 & 0.43 & 0.48 & 0.12 & 0.17 \\
\hline MgO & 10.80 & 10.48 & 12.57 & 8.65 & 8.47 & 11.02 & 8.66 & 12.03 & 8.83 & 11.86 & 8.71 & 14.55 & 9.15 & 11.99 & 12.71 & 13.28 & 6 & 7.66 \\
\hline $\mathrm{CaO}$ & 11.44 & 11.26 & 11.52 & 10.09 & 10.16 & 9.85 & 10.38 & 9.09 & 9.74 & 8.07 & 11.03 & 7.30 & 11.08 & 10.97 & 8.02 & 7.53 & 11.74 & 11.71 \\
\hline $\mathrm{Na}_{2} \mathrm{O}$ & 1.59 & 1.39 & 1.23 & 2.29 & 2.16 & 1.49 & 2.15 & 0.89 & 1.98 & 1.22 & 1.80 & 0.77 & 1.74 & 1.26 & 0.87 & 0.86 & 1.18 & 1.19 \\
\hline $\mathrm{K}_{2} \mathrm{O}$ & 0.27 & 0.31 & 0.17 & 0.19 & 0.20 & 0.16 & 0.17 & 0.23 & 0.19 & 0.18 & 0.28 & 0.10 & 0.30 & 0.20 & 0.11 & 0.12 & 0.38 & 0.38 \\
\hline$F$ & 0.21 & 0.00 & 0.00 & 0.22 & 0.23 & 0.00 & 0.13 & 0.13 & 0.09 & 0.03 & 0.00 & 0.00 & 0.00 & 0.10 & 08 & 0.00 & 0.10 & 0.02 \\
\hline $\mathrm{Cl}$ & 0.01 & 0.01 & 0.02 & 0.00 & 0.00 & 0.00 & 0.02 & 0.00 & 0.02 & 0.01 & 0.01 & 0.01 & 0.00 & 0.01 & 0.00 & 0.01 & 0.00 & 0.02 \\
\hline Total & 97.89 & 96.35 & 97.04 & 97.19 & 97.43 & 96.80 & 97.72 & 97.26 & 95.80 & 96.64 & 98.06 & 97.15 & 97.72 & 98.17 & 98.26 & 96.97 & 97.53 & 96.73 \\
\hline O_F_C & 0.09 & 0.00 & 0.00 & 0.09 & 0.10 & 0.00 & 0.06 & 0.05 & 0.04 & .02 & 0.00 & 0.00 & 0.00 & 0.05 & 0.03 & .00 & 0.04 & 0.01 \\
\hline Si & & & & & & & & & & & & & & & & & & \\
\hline TAI & 850 & 1.882 & 1.463 & 1.885 & 1.886 & 1.396 & 1.916 & 1.051 & 1.976 & 1.247 & 2.161 & 1.109 & 2.174 & 1.471 & 1.020 & 1.120 & 2.003 & 2.079 \\
\hline CAI & 0.909 & 0.850 & 0.639 & 1.049 & 1.034 & 0.668 & 1.011 & 0.486 & 0.859 & 0.482 & 1.243 & 0.263 & 1.166 & 0.673 & 0.676 & 0.604 & 1.170 & 1.167 \\
\hline $\mathrm{Fe}^{3+}$ & 595 & 0.749 & 0.613 & 0.547 & 0.569 & 0.717 & 0.567 & 0.888 & 0.890 & 1.092 & 0.555 & 1.025 & 0.618 & 0.655 & 0.944 & 0.928 & 0.476 & 0.557 \\
\hline $\mathrm{Ti}$ & 0.039 & 0.029 & 0.026 & 0.048 & 0.042 & 0.021 & 0.041 & 0.029 & 0.035 & 0.029 & 0.048 & 0.023 & 0.062 & 0.039 & 0.021 & 0.010 & 0.046 & 0.037 \\
\hline Mg & 2.342 & 2.307 & 2.723 & 1.918 & 1.874 & 2.413 & 1.907 & 2.604 & 1.979 & 2.577 & 1.893 & 3.075 & 1.993 & 2.577 & 2.685 & 2.822 & 1.712 & 1.703 \\
\hline $\mathrm{Fe}^{2+}$ & 1.181 & 1.127 & 1.061 & 1.602 & 1.644 & 1.376 & 1.625 & 1.251 & 1.424 & 1.151 & 1.361 & 1.010 & 1.264 & 1.171 & 0.998 & 0.986 & 1.645 & 1.574 \\
\hline $\mathrm{Ca}$ & 1.783 & 1.782 & 1.795 & 1.608 & 1.617 & 1.551 & 1.643 & 1.414 & 1.569 & 1.260 & 1.723 & 1.109 & 1.734 & 1.695 & 1.218 & 1.150 & 1.862 & 1.871 \\
\hline Mn & 0.036 & 0.041 & 0.034 & 0.021 & 0.018 & 0.018 & 0.017 & 0.020 & 0.016 & 0.022 & 0.030 & 0.031 & 0.024 & 0.028 & 0.051 & 0.058 & 0.015 & 0.022 \\
\hline $\mathrm{Na}$ & 0.448 & 0.399 & 0.347 & 0.661 & 0.621 & 0.425 & 0.614 & 0.251 & 0.576 & 0.345 & 0.509 & 0.211 & 0.493 & 0.354 & 0.239 & 0.239 & 0.339 & 0.346 \\
\hline $\mathrm{K}$ & 0.051 & 0.059 & 0.031 & 0.037 & 0.038 & 0.030 & 0.033 & 0.042 & 0.036 & 0.034 & 0.052 & 0.018 & 0.056 & 0.036 & 0.021 & 0.022 & 0.071 & 0.072 \\
\hline
\end{tabular}

Íns calculados na base de 15 cátions ( $\mathrm{Na}+\mathrm{K}+\mathrm{Ca}), 23 \mathrm{O}$. 
Tabela 2. Análises de biotita usados nos cálculos de geotermobarometria.

\begin{tabular}{|c|c|c|c|c|c|c|c|c|c|c|c|c|c|c|c|c|c|c|c|c|c|}
\hline Análise & 234 & 236 & 388 & 389 & 390 & 391 & 392 & 393 & 394 & 395 & 396 & 397 & 398 & 399 & 400 & 401 & 402 & 412 & 413 & 414 & 415 \\
\hline $\mathrm{SiO}_{2}$ & 35.55 & 34.98 & 34.69 & 34.37 & 35.67 & 34.99 & 35.05 & 34.86 & 35.20 & 34.83 & 35.18 & 34.64 & 34.10 & 34.83 & 34.56 & 35.04 & 34.68 & 33.67 & 34.71 & 34.74 & 34.70 \\
\hline $\mathrm{TiO}_{2}$ & 1.92 & 1.94 & 4.04 & 3.79 & 3.31 & 3.75 & 3.38 & 3.53 & 3.93 & 3.88 & 3.63 & 3.65 & 2.99 & 2.93 & 2.95 & 35.04 & 3.17 & 2.53 & 3.82 & 4.29 & 4.30 \\
\hline $\mathrm{Al}_{2} \mathrm{O}_{3}$ & 18.18 & 18.05 & 18.88 & 19.11 & 20.82 & 18.62 & 18.74 & 18.85 & 19.02 & 19.07 & 18.88 & 18.61 & 19.00 & 18.99 & 18.75 & 35.04 & 18.54 & 19.37 & 18.49 & 18.05 & 17.81 \\
\hline $\mathrm{FeO}$ & 21.59 & 21.21 & 21.75 & 22.46 & 19.45 & 21.50 & 21.32 & 21.47 & 21.27 & 20.60 & 21.63 & 22.22 & 20.74 & 21.32 & 21.57 & 35.04 & 21.38 & 22.21 & 21.87 & 21.56 & 21.88 \\
\hline Mno & 0.07 & 0.02 & 0.05 & 0.09 & 0.04 & 0.12 & 0.12 & 0.09 & 0.08 & 0.03 & 0.09 & 0.10 & 0.09 & 0.06 & 0.05 & 35.04 & 0.09 & 0.06 & 0.14 & 0.10 & 0.09 \\
\hline MgO & 8.03 & 8.26 & 6.32 & 6.22 & 6.12 & 6.69 & 6.70 & 6.62 & 6.26 & 6.68 & 6.50 & 6.42 & 7.92 & 7.39 & 7.19 & 35.04 & 6.97 & 6.85 & 6.46 & 6.61 & 6.48 \\
\hline $\mathrm{CaO}$ & 0.03 & 0.06 & 0.01 & 0.00 & 0.00 & 0.00 & 0.00 & 0.00 & 0.00 & 0.00 & 0.00 & 0.00 & 0.00 & 0.00 & 0.01 & 35.04 & 0.02 & 0.02 & 0.03 & 0.02 & 0.01 \\
\hline $\mathrm{Na}_{2} \mathrm{O}$ & 0.15 & 0.11 & 0.10 & 0.08 & 0.11 & 0.08 & 0.12 & 0.09 & 0.07 & 0.10 & 0.09 & 0.08 & 0.06 & 0.10 & 0.09 & 35.04 & 0.10 & 0.11 & 0.07 & 0.12 & 0.13 \\
\hline $\mathrm{K}_{2} \mathrm{O}$ & 9.06 & 8.67 & 8.42 & 8.13 & 7.57 & 8.36 & 8.48 & 8.30 & 8.31 & 8.26 & 8.63 & 8.42 & 8.10 & 8.33 & 8.19 & 8.31 & 8.39 & 7.15 & 8.13 & 8.41 & 8.50 \\
\hline $\mathrm{Cl}$ & 0.01 & 0.02 & 0.01 & 0.00 & 0.00 & 0.01 & 0.00 & 0.00 & 0.00 & 0.00 & 0.01 & 0.01 & 0.01 & 0.00 & 0.00 & 0.00 & 0.01 & 0.01 & 0.00 & 0.00 & 0.01 \\
\hline$F$ & 0.16 & 0.17 & 0.19 & 0.02 & 0.32 & 0.30 & 0.13 & 0.13 & 0.17 & 0.28 & 0.17 & 0.26 & 0.31 & 0.24 & 0.13 & 0.15 & 0.23 & 0.16 & 0.26 & 0.27 & 0.35 \\
\hline $\mathrm{BaO}$ & 0.56 & 0.45 & 0.21 & 0.17 & 0.06 & 0.17 & 0.17 & 0.06 & 0.14 & 0.16 & 0.08 & 0.28 & 0.10 & 0.12 & 0.27 & 0.18 & 0.05 & 0.09 & 0.11 & 0.07 & 0.07 \\
\hline Total & 95.30 & 93.95 & 94.67 & 94.43 & 93.47 & 94.59 & 94.23 & 94.00 & 94.46 & 93.90 & 94.89 & 94.69 & 93.41 & 94.30 & 93.77 & 94.20 & 93.62 & 92.21 & 94.10 & 94.24 & 94.32 \\
\hline O_F_Cl & 0.07 & 0.08 & 0.08 & 0.01 & 0.13 & 0.13 & 0.06 & 0.05 & 0.07 & 0.12 & 0.07 & 0.11 & 0.13 & 0.10 & 0.06 & 0.06 & 0.10 & 0.07 & 0.11 & 0.11 & 0.15 \\
\hline $\mathrm{Si}$ & 5.742 & 5.717 & 5.616 & 5.579 & 5.717 & 5.665 & 5.683 & 5.659 & 5.679 & 5.646 & 5.671 & 5.631 & 5.570 & 5.642 & 5.640 & 5.682 & 5.667 & 5.574 & 5.653 & 5.652 & 5.661 \\
\hline $\mathrm{Al}^{\mathrm{IV}}$ & 2.258 & 2.283 & 2.384 & 2.421 & 2.283 & 2.335 & 2.317 & 2.341 & 2.321 & 2.354 & 2.329 & 2.369 & 2.430 & 2.358 & 2.360 & 2.318 & 2.333 & 2.426 & 2.347 & 2.348 & 2.339 \\
\hline $\mathrm{Al}^{\mathrm{VI}}$ & 1.200 & 1.190 & 1.215 & 1.232 & 1.645 & 1.215 & 1.262 & 1.264 & 1.293 & 1.288 & 1.256 & 1.194 & 1.225 & 1.264 & 1.244 & 1.292 & 1.236 & 1.349 & 1.199 & 1.112 & 1.084 \\
\hline $\mathrm{Ti}$ & 0.233 & 0.239 & 0.492 & 0.463 & 0.399 & 0.457 & 0.413 & 0.430 & 0.477 & 0.474 & 0.440 & 0.447 & 0.368 & 0.356 & 0.362 & 0.366 & 0.390 & 0.315 & 0.468 & 0.525 & 0.527 \\
\hline $\mathrm{Fe}^{2+}$ & 2.916 & 2.898 & 2.945 & 3.049 & 2.607 & 2.911 & 2.891 & 2.916 & 2.870 & 2.793 & 2.916 & 3.022 & 2.819 & 2.840 & 2.781 & 2.916 & 2.986 & 3.075 & 2.979 & 2.935 & 2.985 \\
\hline Mn & 0.010 & 0.003 & 0.007 & 0.013 & 0.006 & 0.017 & 0.016 & 0.013 & 0.011 & 0.005 & 0.012 & 0.014 & 0.012 & 0.009 & 0.007 & 0.011 & 0.012 & 0.009 & 0.020 & 0.014 & 0.013 \\
\hline $\mathbf{M g}$ & 1.933 & 2.013 & 1.526 & 1.505 & 1.461 & 1.613 & 1.620 & 1.602 & 1.506 & 1.614 & 1.563 & 1.555 & 1.929 & 1.784 & 1.749 & 1.667 & 1.697 & 1.690 & 1.568 & 1.604 & 1.576 \\
\hline $\mathrm{Ba}$ & 0.035 & 0.029 & 0.013 & 0.011 & 0.004 & 0.011 & 0.011 & 0.004 & 0.009 & 0.010 & 0.005 & 0.018 & 0.006 & 0.007 & 0.017 & 0.012 & 0.003 & 0.006 & 0.007 & 0.005 & 0.004 \\
\hline $\mathrm{Ca}$ & 0.005 & 0.011 & 0.002 & 0.002 & 0.002 & 0.002 & 0.002 & 0.002 & 0.002 & 0.001 & 0.000 & 0.000 & 0.000 & 0.000 & 0.002 & 0.005 & 0.004 & 0.003 & 0.005 & 0.003 & 0.002 \\
\hline $\mathrm{Na}$ & 0.045 & 0.034 & 0.030 & 0.026 & 0.035 & 0.024 & 0.038 & 0.028 & 0.023 & 0.032 & 0.028 & 0.024 & 0.020 & 0.032 & 0.027 & 0.032 & 0.031 & 0.034 & 0.022 & 0.038 & 0.040 \\
\hline $\mathrm{K}$ & 1.867 & 1.808 & 1.739 & 1.683 & 1.547 & 1.727 & 1.755 & 1.720 & 1.709 & 1.708 & 1.774 & 1.747 & 1.687 & 1.721 & 1.705 & 1.719 & 1.749 & 1.510 & 1.689 & 1.745 & 1.769 \\
\hline
\end{tabular}

Îns calculados na base de 16 cátions, $22 \mathrm{O}$. 
Tabela 3. Análises de granada usados nos cálculos de geotermobarometria.

\begin{tabular}{|c|c|c|c|c|c|c|c|c|c|c|c|c|c|c|c|c|c|c|c|c|c|}
\hline Análise & 001 & 003 & 007 & 012 & 014 & 015 & 016 & 017 & 018 & 020 & 021 & 023 & 026 & 027 & 028 & 029 & 030 & 031 & 032 & 034 & 036 \\
\hline $\mathrm{SiO}_{2}$ & 38.16 & 37.93 & 38.50 & 37.66 & 38.10 & 38.52 & 37.81 & 38.16 & 38.12 & 37.83 & 38.34 & 37.98 & 38.34 & 38.25 & 38.13 & 37.99 & 37.77 & 37.92 & 37.15 & 37.51 & 36.96 \\
\hline $\mathrm{Al}_{2} \mathrm{O}_{3}$ & 21.51 & 20.83 & 21.66 & 20.95 & 21.30 & 21.50 & 21.22 & 21.30 & 21.35 & 21.09 & 21.11 & 21.33 & 21.57 & 21.41 & 21.18 & 20.94 & 21.19 & 21.19 & 20.46 & 20.57 & 20.39 \\
\hline $\mathrm{TiO}_{2}$ & 0.17 & 0.49 & 0.09 & 0.15 & 0.05 & 0.13 & 0.28 & 0.14 & 0.09 & 0.15 & 0.15 & 0.09 & 0.12 & 0.17 & 0.15 & 0.17 & 0.13 & 0.11 & 0.19 & 0.13 & 0.13 \\
\hline $\mathrm{FeO}$ & 27.44 & 27.02 & 27.53 & 27.05 & 27.43 & 27.44 & 27.70 & 28.11 & 27.77 & 27.53 & 26.65 & 27.58 & 27.15 & 27.13 & 28.42 & 27.25 & 26.85 & 27.78 & 30.82 & 28.46 & 30.02 \\
\hline MnO & 0.83 & 2.16 & 0.53 & 1.97 & 0.47 & 0.71 & 1.86 & 0.58 & 0.50 & 1.85 & 2.34 & 0.61 & 0.76 & 0.55 & 0.86 & 2.59 & 1.67 & 0.73 & 0.54 & 1.68 & .36 \\
\hline MgO & 2.54 & 1.34 & 3.15 & 1.38 & 2.80 & 2.68 & 1.70 & 2.18 & 2.47 & 1.69 & 1.76 & 2.82 & 2.96 & 2.59 & 2.21 & 1.57 & 1.78 & 2.30 & 1.34 & 1.00 & 1.39 \\
\hline $\mathrm{CaO}$ & 9.54 & 9.90 & 8.64 & 9.93 & 8.98 & 9.38 & 9.27 & 9.69 & 9.67 & 9.36 & 9.69 & 8.90 & 9.26 & 9.95 & 9.28 & 9.43 & 9.89 & 9.30 & 8.74 & 9.72 & 8.70 \\
\hline $\mathrm{Na}_{2} \mathrm{O}$ & 0.01 & 0.02 & 0.02 & 0.01 & 0.02 & 0.03 & 0.02 & 0.00 & 0.02 & 0.00 & 0.01 & 0.01 & 0.02 & 0.00 & 0.00 & 0.03 & 0.02 & 0.03 & 0.02 & 0.01 & 0.01 \\
\hline $\mathrm{Cr}_{2} \mathrm{O}_{3}$ & 0.00 & 0.03 & 0.02 & 0.04 & 0.03 & 0.02 & 0.03 & 0.01 & 0.00 & 0.00 & 0.02 & 0.00 & 0.04 & 0.03 & 0.00 & 0.01 & 0.00 & 0.04 & 0.02 & 0.04 & 0.05 \\
\hline $\mathrm{Y}_{2} \mathrm{O}_{3}$ & 0.00 & 0.00 & 0.00 & 0.00 & 0.01 & 0.01 & 0.00 & 0.01 & 0.00 & 0.01 & 0.00 & 0.01 & 0.02 & 0.00 & 0.04 & 0.00 & 0.00 & 0.00 & 0.01 & 0.00 & 0.00 \\
\hline Total & 100.19 & 99.72 & 100.14 & 99.14 & 99.19 & 100.41 & 99.89 & 100.18 & 99.99 & 99.51 & 100.06 & 99.33 & 100.24 & 100.08 & 100.26 & 99.98 & 99.30 & 99.40 & 99.27 & 99.12 & 98.02 \\
\hline Si & 3.013 & 3.037 & 3.033 & 3.029 & 3.036 & 3.033 & 3.017 & 3.023 & 3.017 & 3.029 & 3.048 & 3.023 & 3.019 & 3.021 & 3.023 & 3.031 & 3.022 & 3.025 & 3.001 & 3.031 & 3.019 \\
\hline $\mathrm{Al}^{\mathrm{VI}}$ & 2.000 & 1.964 & 2.009 & 1.984 & 1.998 & 1.993 & 1.993 & 1.987 & 1.991 & 1.988 & 1.977 & 1.999 & 2.000 & 1.991 & 1.977 & 1.968 & 1.997 & 1.991 & 1.947 & 1.957 & 1.961 \\
\hline $\mathrm{Ti}$ & 0.010 & 0.029 & 0.005 & 0.009 & 0.003 & 0.008 & 0.017 & 0.008 & 0.005 & 0.009 & 0.009 & 0.006 & 0.007 & 0.010 & 0.009 & 0.010 & 0.008 & 0.007 & 0.012 & 0.008 & 0.008 \\
\hline $\mathrm{Cr}$ & 0.000 & 0.002 & 0.001 & 0.002 & 0.002 & 0.001 & 0.002 & 0.000 & 0.000 & 0.000 & 0.001 & 0.000 & 0.002 & 0.002 & 0.000 & 0.000 & 0.000 & 0.002 & 0.001 & 0.003 & 0.003 \\
\hline $\mathrm{Fe}^{2+}$ & 1.813 & 1.809 & 1.814 & 1.819 & 1.828 & 1.807 & 1.848 & 1.862 & 1.838 & 1.843 & 1.772 & 1.836 & 1.788 & 1.792 & 1.884 & 1.818 & 1.796 & 1.853 & 2.082 & 1.923 & 2.050 \\
\hline Mg & 0.299 & 0.160 & 0.370 & 0.165 & 0.333 & 0.314 & 0.202 & 0.258 & 0.292 & 0.202 & 0.209 & 0.334 & 0.348 & 0.305 & 0.261 & 0.186 & 0.213 & 0.274 & 0.161 & 0.120 & 0.169 \\
\hline Mn & 0.056 & 0.146 & 0.035 & 0.134 & 0.032 & 0.047 & 0.125 & 0.039 & 0.033 & 0.126 & 0.157 & 0.041 & 0.051 & 0.037 & 0.058 & 0.175 & 0.113 & 0.049 & 0.037 & 0.115 & 0.025 \\
\hline $\mathrm{Ca}$ & 0.807 & 0.849 & 0.729 & 0.855 & 0.766 & 0.792 & 0.792 & 0.823 & 0.820 & 0.803 & 0.825 & 0.759 & 0.782 & 0.842 & 0.788 & 0.806 & 0.848 & 0.795 & 0.756 & 0.841 & 0.762 \\
\hline $\mathrm{Na}$ & 0.002 & 0.003 & 0.003 & 0.002 & 0.003 & 0.004 & 0.004 & 0.000 & 0.003 & 0.001 & 0.002 & 0.001 & 0.002 & 0.000 & 0.001 & 0.005 & 0.004 & 0.004 & 0.002 & 0.002 & 0.002 \\
\hline Alm & 60.903 & 60.957 & 61.472 & 61.141 & 61.720 & 60.945 & 62.198 & 62.459 & 61.551 & 61.984 & 59.764 & 61.785 & 60.193 & 60.203 & 62.993 & 60.799 & 60.410 & 62.280 & 68.529 & 64.069 & 68.155 \\
\hline Grs & 27.111 & 28.498 & 24.649 & 28.626 & 25.784 & 26.657 & 26.554 & 27.567 & 27.459 & 26.984 & 27.776 & 25.545 & 26.186 & 28.219 & 26.334 & 26.940 & 28.506 & 26.606 & 24.814 & 27.883 & 25.142 \\
\hline Prp & 10.045 & 5.401 & 12.525 & 5.548 & 11.235 & 10.609 & 6.805 & 8.651 & 9.775 & 6.791 & 7.040 & 11.249 & 11.708 & 10.261 & 8.716 & 6.233 & 7.156 & 9.205 & 5.300 & 4.013 & 5.626 \\
\hline Sps & 1.870 & 4.924 & 1.198 & 4.498 & 1.076 & 1.595 & 4.219 & 1.301 & 1.118 & 4.221 & 5.308 & 1.375 & 1.713 & 1.238 & 1.933 & 5.846 & 3.808 & 1.658 & 1.205 & 3.826 & 0.835 \\
\hline
\end{tabular}

Íns calculados na base de 8 cátions, $24 \mathrm{O}$. 
Tabela 4. Análises de granada usados nos cálculos de geotermobarometria (continuação).

\begin{tabular}{|c|c|c|c|c|c|c|c|c|c|c|c|c|c|c|c|c|c|c|c|c|c|}
\hline Análise & 046 & 051 & 054 & 059 & 060 & 157 & 158 & 159 & 160 & 161 & 162 & 163 & 164 & 165 & 166 & 167 & 168 & 169 & 170 & 171 & 184 \\
\hline $\mathrm{SiO}_{2}$ & 37.35 & 37.19 & 37.98 & 37.76 & 37.81 & 37.26 & 36.70 & 35.92 & 36.51 & 37.06 & 36.43 & 36.67 & 36.46 & 37.06 & 35.99 & 36.22 & 37.29 & 36.58 & 36.54 & 36.71 & 37.33 \\
\hline $\mathrm{Al}_{2} \mathrm{O}_{3}$ & 20.74 & 20.62 & 21.40 & 21.21 & 21.22 & 21.45 & 21.06 & 20.78 & 20.80 & 21.00 & 20.80 & 20.72 & 20.64 & 20.87 & 20.63 & 20.71 & 21.14 & 20.92 & 20.77 & 20.88 & 20.86 \\
\hline $\mathrm{TiO}_{2}$ & 0.10 & 0.13 & 0.09 & 0.05 & 0.14 & 0.00 & 0.15 & 0.11 & 0.06 & 0.05 & 0.06 & 0.11 & 0.07 & 0.10 & 0.08 & 0.04 & 0.05 & 0.08 & 0.07 & 0.09 & 0.09 \\
\hline $\mathrm{FeO}$ & 28.62 & 29.64 & 26.00 & 26.96 & 27.60 & 33.96 & 24.98 & 23.62 & 25.63 & 33.30 & 28.52 & 23.98 & 23.74 & 27.11 & 30.17 & 24.58 & 33.21 & 26.46 & 24.36 & 23.66 & 33.93 \\
\hline MnO & 0.94 & 0.50 & 0.61 & 0.20 & 0.26 & 4.29 & 13.48 & 14.62 & 12.25 & 4.43 & 10.19 & 14.41 & 14.74 & 11.75 & 7.74 & 14.06 & 4.52 & 11.79 & 13.82 & 14.51 & 0.22 \\
\hline MgO & 1.15 & 1.43 & 2.53 & 2.46 & 2.37 & 2.11 & 1.13 & 1.04 & 1.18 & 2.17 & 1.39 & 1.09 & 1.07 & 1.20 & 1.59 & 1.10 & 2.23 & 1.24 & 1.08 & 1.05 & 1.99 \\
\hline $\mathrm{CaO}$ & 10.04 & 8.99 & 10.27 & 9.97 & 10.06 & 1.35 & 1.72 & 1.49 & 1.60 & 1.77 & 1.72 & 1.65 & 1.68 & 1.90 & 1.81 & 1.63 & 1.47 & 1.69 & 1.53 & 1.59 & 4.00 \\
\hline $\mathrm{Na}_{2} \mathrm{O}$ & 0.02 & 0.02 & 0.02 & 0.01 & 0.02 & 0.02 & 0.00 & 0.02 & 0.03 & 0.01 & 0.01 & 0.02 & 0.01 & 0.01 & 0.02 & 0.01 & 0.02 & 0.01 & 0.02 & 0.01 & 0.02 \\
\hline $\mathrm{Cr}_{2} \mathrm{O}_{3}$ & 0.03 & 0.02 & 0.01 & 0.02 & 0.05 & 0.02 & 0.00 & 0.03 & 0.02 & 0.00 & 0.03 & 0.02 & 0.01 & 0.00 & 0.02 & 0.00 & 0.02 & 0.03 & 0.01 & 0.03 & 0.00 \\
\hline $\mathrm{Y}_{2} \mathrm{O}_{3}$ & 0.02 & 0.00 & 0.05 & 0.00 & 0.00 & 0.05 & 0.30 & 0.44 & 0.26 & 0.05 & 0.12 & 0.36 & 0.37 & 0.29 & 0.03 & 0.33 & 0.08 & 0.30 & 0.38 & 0.37 & 0.00 \\
\hline Total & 99.02 & 98.53 & 98.96 & 98.65 & 99.53 & 100.51 & 99.53 & 98.07 & 98.33 & 99.84 & 99.27 & 99.02 & 98.80 & 100.29 & 98.08 & 98.68 & 100.03 & 99.08 & 98.58 & 98.89 & 98.43 \\
\hline Si & 3.015 & 3.017 & 3.028 & 3.024 & 3.007 & 3.005 & 3.012 & 2.999 & 3.030 & 3.007 & 2.992 & 3.029 & 3.020 & 3.019 & 2.984 & 3.003 & 3.020 & 3.015 & 3.031 & 3.035 & 3.054 \\
\hline $\mathrm{Al}^{\mathrm{VI}}$ & 1.971 & 1.970 & 2.010 & 2.001 & 1.987 & 2.037 & 2.036 & 2.042 & 2.033 & 2.007 & 2.004 & 2.016 & 2.013 & 2.002 & 1.999 & 2.022 & 2.016 & 2.030 & 2.029 & 2.033 & 2.009 \\
\hline $\mathrm{Ti}$ & 0.006 & 0.008 & 0.006 & 0.003 & 0.008 & 0.000 & 0.009 & 0.007 & 0.004 & 0.003 & 0.004 & 0.007 & 0.004 & 0.006 & 0.005 & 0.002 & 0.003 & 0.005 & 0.004 & 0.005 & 0.005 \\
\hline $\mathrm{Cr}$ & 0.002 & 0.001 & 0.000 & 0.001 & 0.003 & 0.001 & 0.000 & 0.002 & 0.001 & 0.000 & 0.002 & 0.001 & 0.001 & 0.000 & 0.001 & 0.000 & 0.001 & 0.002 & 0.001 & 0.002 & 0.000 \\
\hline $\mathrm{Fe}^{2+}$ & 1.932 & 2.011 & 1.734 & 1.806 & 1.835 & 2.290 & 1.715 & 1.649 & 1.779 & 2.260 & 1.959 & 1.656 & 1.644 & 1.847 & 2.092 & 1.704 & 2.249 & 1.823 & 1.690 & 1.636 & 2.321 \\
\hline Mg & 0.138 & 0.173 & 0.300 & 0.294 & 0.281 & 0.253 & 0.139 & 0.130 & 0.146 & 0.263 & 0.170 & 0.134 & 0.132 & 0.146 & 0.196 & 0.136 & 0.269 & 0.152 & 0.133 & 0.129 & 0.242 \\
\hline Mn & 0.064 & 0.034 & 0.041 & 0.014 & 0.017 & 0.293 & 0.937 & 1.034 & 0.861 & 0.305 & 0.709 & 1.008 & 1.034 & 0.811 & 0.544 & 0.987 & 0.310 & 0.823 & 0.971 & 1.016 & 0.015 \\
\hline $\mathrm{Ca}$ & 0.868 & 0.781 & 0.877 & 0.855 & 0.857 & 0.117 & 0.151 & 0.133 & 0.142 & 0.154 & 0.152 & 0.146 & 0.149 & 0.166 & 0.161 & 0.145 & 0.128 & 0.149 & 0.136 & 0.140 & 0.351 \\
\hline $\mathrm{Na}$ & 0.004 & 0.004 & 0.003 & 0.002 & 0.004 & 0.003 & 0.000 & 0.003 & 0.005 & 0.002 & 0.001 & 0.003 & 0.002 & 0.002 & 0.003 & 0.002 & 0.004 & 0.002 & 0.003 & 0.002 & 0.003 \\
\hline Alm & 64.260 & 66.960 & 58.658 & 60.796 & 61.309 & 77.477 & 58.289 & 55.929 & 60.659 & 75.743 & 65.495 & 56.181 & 55.516 & 62.150 & 69.852 & 57.308 & 75.981 & 61.834 & 57.600 & 55.961 & 79.172 \\
\hline Grs & 28.785 & 25.949 & 29.664 & 28.719 & 28.466 & 3.871 & 5.147 & 4.415 & 4.794 & 5.166 & 4.989 & 4.905 & 4.994 & 5.571 & 5.297 & 4.869 & 4.251 & 4.965 & 4.602 & 4.709 & 11.955 \\
\hline Prp & 4.603 & 5.759 & 10.161 & 9.883 & 9.369 & 8.569 & 4.716 & 4.394 & 4.970 & 8.810 & 5.695 & 4.541 & 4.469 & 4.917 & 6.542 & 4.563 & 9.100 & 5.170 & 4.544 & 4.426 & 8.261 \\
\hline Sps & 2.133 & 1.142 & 1.389 & 0.461 & 0.574 & 9.922 & 31.848 & 35.072 & 29.369 & 10.212 & 23.709 & 34.205 & 34.921 & 27.286 & 18.152 & 33.195 & 10.479 & 27.894 & 33.094 & 34.751 & 0.520 \\
\hline
\end{tabular}

İons calculados na base de 8 cátions, $24 \mathrm{O}$. 
Tabela 5 Análises de granada usados nos cálculos de geotermobarometria (continuação).

\begin{tabular}{|c|c|c|c|c|c|c|c|c|c|c|c|c|c|c|c|c|c|c|c|}
\hline Análise & 187 & 194 & 195 & 196 & 305 & 310 & 313 & 357 & 364 & 371 & 372 & 373 & 374 & 375 & 376 & 378 & 381 & 386 & 387 \\
\hline $\mathrm{SiO}_{2}$ & 37.27 & 36.68 & 37.08 & 36.72 & 36.75 & 36.40 & 37.16 & 37.11 & 37.04 & 37.14 & 36.92 & 37.28 & 37.31 & 37.35 & 37.02 & 37.29 & 37.20 & 36.83 & 37.00 \\
\hline $\mathrm{Al}_{2} \mathrm{O}_{3}$ & 20.79 & 21.06 & 20.79 & 20.69 & 27.00 & 20.43 & 20.81 & 21.02 & 21.08 & 20.97 & 21.02 & 21.08 & 21.08 & 20.86 & 21.04 & 20.86 & 21.00 & 20.75 & 20.70 \\
\hline $\mathrm{TiO}_{2}$ & 0.13 & 0.08 & 0.07 & 0.10 & 0.00 & 0.03 & 0.05 & 0.00 & 0.05 & 0.00 & 0.03 & 0.07 & 0.00 & 0.02 & 0.00 & 0.04 & 0.00 & 0.01 & 0.06 \\
\hline $\mathrm{FeO}$ & 34.84 & 33.03 & 29.96 & 26.96 & 28.68 & 34.87 & 35.14 & 34.82 & 33.91 & 34.84 & 34.95 & 34.62 & 34.88 & 34.92 & 34.83 & 34.86 & 34.01 & 34.53 & 34.26 \\
\hline MnO & 0.08 & 4.58 & 9.00 & 11.58 & 2.67 & 3.19 & 2.86 & 2.52 & 2.95 & 2.94 & 2.98 & 2.91 & 3.12 & 2.89 & 3.02 & 2.43 & 2.73 & 3.05 & 3.03 \\
\hline MgO & 1.99 & 2.12 & 1.42 & 1.22 & 2.56 & 2.18 & 2.26 & 2.83 & 3.06 & 2.28 & 2.29 & 2.20 & 2.16 & 2.26 & 2.51 & 2.68 & 2.57 & 2.31 & 2.36 \\
\hline $\mathrm{CaO}$ & 4.13 & 1.37 & 1.82 & 1.71 & 0.54 & 0.87 & 0.91 & 0.73 & 0.63 & 0.83 & 0.82 & 0.89 & 0.85 & 0.89 & 0.91 & 0.85 & 0.71 & 0.81 & 0.86 \\
\hline $\mathrm{Na}_{2} \mathrm{O}$ & 0.02 & 0.02 & 0.04 & 0.02 & 0.02 & 0.00 & 0.01 & 0.01 & 0.04 & 0.00 & 0.01 & 0.01 & 0.00 & 0.01 & 0.02 & 0.00 & 0.00 & 0.00 & 0.01 \\
\hline $\mathrm{Cr}_{2} \mathrm{O}_{3}$ & 0.00 & 0.02 & 0.03 & 0.04 & 0.03 & 0.00 & 0.03 & 0.01 & 0.03 & 0.01 & 0.03 & 0.00 & 0.00 & 0.01 & 0.00 & 0.00 & 0.00 & 0.00 & 0.04 \\
\hline $\mathrm{Y}_{2} \mathrm{O}_{3}$ & 0.00 & 0.05 & 0.11 & 0.36 & 0.06 & 0.01 & 0.04 & 0.00 & 0.06 & 0.00 & 0.01 & 0.00 & 0.02 & 0.01 & 0.00 & 0.00 & 0.08 & 0.01 & 0.00 \\
\hline Total & 99.24 & 99.01 & 100.30 & 99.40 & 98.33 & 97.98 & 99.26 & 99.05 & 98.84 & 99.01 & 99.06 & 99.07 & 99.42 & 99.21 & 99.34 & 99.00 & 98.31 & 98.30 & 98.31 \\
\hline Si & 3.028 & 3.003 & 3.013 & 3.021 & 2.961 & 3.017 & 3.037 & 3.025 & 3.021 & 3.039 & 3.020 & 3.048 & 3.043 & 3.052 & 3.015 & 3.044 & 3.059 & 3.036 & 3.048 \\
\hline $\mathrm{Al}^{\mathrm{VI}}$ & 1.989 & 2.030 & 1.989 & 2.004 & 2.524 & 1.994 & 2.002 & 2.018 & 2.025 & 2.021 & 2.025 & 2.031 & 2.025 & 2.007 & 2.018 & 2.005 & 2.033 & 2.015 & 2.008 \\
\hline $\mathrm{Ti}$ & 0.008 & 0.005 & 0.004 & 0.006 & 0.000 & 0.002 & 0.003 & 0.000 & 0.003 & 0.000 & 0.002 & 0.004 & 0.000 & 0.001 & 0.000 & 0.003 & 0.000 & 0.000 & 0.004 \\
\hline $\mathrm{Cr}$ & 0.000 & 0.001 & 0.002 & 0.002 & 0.002 & 0.000 & 0.002 & 0.001 & 0.002 & 0.001 & 0.002 & 0.000 & 0.000 & 0.000 & 0.000 & 0.000 & 0.000 & 0.000 & 0.002 \\
\hline $\mathrm{Fe}^{2+}$ & 2.367 & 2.261 & 2.036 & 1.855 & 1.933 & 2.417 & 2.401 & 2.374 & 2.313 & 2.384 & 2.391 & 2.368 & 2.379 & 2.386 & 2.373 & 2.380 & 2.339 & 2.380 & 2.360 \\
\hline Mg & 0.241 & 0.259 & 0.172 & 0.150 & 0.308 & 0.269 & 0.275 & 0.344 & 0.372 & 0.279 & 0.279 & 0.268 & 0.263 & 0.275 & 0.305 & 0.326 & 0.316 & 0.284 & 0.289 \\
\hline Mn & 0.005 & 0.318 & 0.620 & 0.807 & 0.182 & 0.224 & 0.198 & 0.174 & 0.204 & 0.203 & 0.207 & 0.202 & 0.215 & 0.200 & 0.208 & 0.168 & 0.190 & 0.213 & 0.212 \\
\hline $\mathrm{Ca}$ & 0.359 & 0.120 & 0.158 & 0.151 & 0.047 & 0.077 & 0.080 & 0.064 & 0.055 & 0.073 & 0.072 & 0.078 & 0.074 & 0.078 & 0.079 & 0.074 & 0.063 & 0.071 & 0.076 \\
\hline $\mathrm{Na}$ & 0.003 & 0.003 & 0.006 & 0.003 & 0.004 & 0.000 & 0.002 & 0.001 & 0.006 & 0.000 & 0.002 & 0.001 & 0.000 & 0.001 & 0.002 & 0.000 & 0.000 & 0.000 & 0.001 \\
\hline Alm & 79.543 & 76.370 & 68.061 & 62.548 & 78.125 & 80.915 & 81.236 & 80.282 & 0.000 & 81.110 & 81.024 & 81.180 & 81.150 & 81.163 & 79.964 & 80.734 & 80.447 & 80.725 & 80.330 \\
\hline Grs & 12.081 & 3.989 & 5.201 & 4.968 & 1.815 & 2.593 & 2.614 & 2.130 & 0.000 & 2.453 & 2.322 & 2.676 & 2.527 & 2.628 & 2.667 & 2.516 & 2.158 & 2.423 & 2.461 \\
\hline Prp & 8.100 & 8.741 & 5.762 & 5.061 & 12.450 & 9.002 & 9.294 & 11.635 & 0.000 & 9.479 & 9.468 & 9.203 & 8.975 & 9.363 & 10.279 & 11.063 & 10.853 & 9.631 & 9.851 \\
\hline Sps & 0.180 & 10.727 & 20.708 & 27.214 & 7.375 & 7.491 & 6.704 & 5.889 & 0.000 & 6.921 & 7.007 & 6.913 & 7.341 & 6.803 & 7.010 & 5.687 & 6.543 & 7.222 & 7.202 \\
\hline
\end{tabular}

Íns calculados na base de 8 cátions, $24 \mathrm{O}$. 
Tabela 6. Análises de muscovita usados nos cálculos de geotermobarometria.

\begin{tabular}{|c|c|c|c|c|c|c|c|c|c|c|c|c|c|c|c|c|c|c|c|c|}
\hline \multicolumn{13}{|c|}{ Muscovita amostra 53} & \multicolumn{8}{|c|}{ Muscovita amostra 46} \\
\hline Análise & 421 & 422 & 426 & 428 & 430 & 448 & 449 & 450 & 454 & 455 & 456 & 458 & Análise & 463 & 472 & 473 & 475 & 476 & 477 & 480 \\
\hline $\mathrm{SiO}_{2}$ & 45.71 & 45.94 & 45.69 & 46.00 & 45.53 & 46.10 & 45.43 & 45.73 & 46.00 & 45.69 & 46.05 & 45.75 & $\mathrm{SiO}_{2}$ & 45.25 & 45.34 & 45.44 & 45.24 & 45.25 & 45.49 & 45.50 \\
\hline $\mathrm{TiO}_{2}$ & 0.96 & 0.89 & 0.57 & 0.79 & 0.78 & 0.87 & 0.68 & 0.91 & 0.82 & 0.87 & 0.76 & 0.86 & $\mathrm{TiO}_{2}$ & 0.15 & 0.33 & 0.36 & 0.12 & 0.33 & 0.32 & 0.34 \\
\hline $\mathrm{Al}_{2} \mathrm{O} 3$ & 34.99 & 35.09 & 34.49 & 34.65 & 34.74 & 34.66 & 34.94 & 34.51 & 34.41 & 34.97 & 34.44 & 34.39 & $\mathrm{Al}_{2} \mathrm{O} 3$ & 33.80 & 33.72 & 33.37 & 33.84 & 33.85 & 33.72 & 33.37 \\
\hline $\mathrm{FeO}$ & 1.45 & 1.16 & 1.12 & 1.21 & 1.21 & 1.37 & 1.40 & 1.36 & 1.30 & 1.26 & 1.48 & 1.32 & $\mathrm{Cr}_{2} \mathrm{O} 3$ & 0.02 & 0.00 & 0.01 & 0.03 & 0.01 & 0.04 & 0.00 \\
\hline MnO & 0.02 & 0.00 & 0.00 & 0.00 & 0.03 & 0.01 & 0.02 & 0.02 & 0.00 & 0.00 & 0.00 & 0.00 & $\mathrm{FeO}$ & 2.17 & 2.05 & 2.04 & 1.87 & 2.09 & 2.21 & 2.33 \\
\hline MgO & 0.54 & 0.65 & 0.63 & 0.66 & 0.66 & 0.71 & 0.63 & 0.61 & 0.65 & 0.66 & 0.66 & 0.66 & MnO & 0.02 & 0.00 & 0.03 & 0.00 & 0.01 & 0.03 & 0.01 \\
\hline $\mathrm{CaO}$ & 0.00 & 0.00 & 0.00 & 0.00 & 0.00 & 0.00 & 0.00 & 0.00 & 0.00 & 0.02 & 0.00 & 0.00 & MgO & 0.98 & 1.01 & 1.12 & 0.91 & 0.96 & 1.00 & 1.08 \\
\hline $\mathrm{Na}_{2} \mathrm{O}$ & 0.55 & 0.51 & 0.49 & 0.49 & 0.54 & 0.42 & 0.53 & 0.52 & 0.50 & 0.44 & 0.51 & 0.52 & $\mathrm{CaO}$ & 0.00 & 0.06 & 0.04 & 0.00 & 0.03 & 0.02 & 0.01 \\
\hline $\mathrm{K}_{2} \mathrm{O}$ & 9.54 & 9.71 & 9.76 & 9.75 & 9.73 & 9.32 & 9.72 & 9.79 & 9.51 & 9.06 & 9.47 & 9.38 & $\mathrm{BaO}$ & 1.02 & 1.05 & 1.25 & 0.87 & 1.26 & 1.08 & 1.12 \\
\hline $\mathrm{Cl}$ & 0.00 & 0.01 & 0.00 & 0.01 & 0.00 & 0.00 & 0.00 & 0.01 & 0.00 & 0.00 & 0.00 & 0.00 & $\mathrm{Na}_{2} \mathrm{O}$ & 0.55 & 0.59 & 0.51 & 0.55 & 0.55 & 0.56 & 0.53 \\
\hline $\mathbf{F}$ & 0.10 & 0.00 & 0.07 & 0.13 & 0.08 & 0.04 & 0.00 & 0.00 & 0.04 & 0.00 & 0.08 & 0.06 & $\mathrm{~K}_{2} \mathrm{O}$ & 9.30 & 9.32 & 9.62 & 9.67 & 9.45 & 9.57 & 9.54 \\
\hline $\mathrm{BaO}$ & 0.22 & 0.04 & 0.23 & 0.24 & 0.21 & 0.20 & 0.22 & 0.20 & 0.17 & 0.26 & 0.12 & 0.18 & $\mathrm{Cl}$ & 0.00 & 0.00 & 0.00 & 0.00 & 0.01 & 0.00 & 0.00 \\
\hline Total & 94.07 & 94.00 & 93.04 & 93.93 & 93.49 & 93.69 & 93.56 & 93.65 & 93.40 & 93.21 & 93.56 & 93.11 & Total & 93.27 & 93.46 & 93.77 & 93.09 & 93.79 & 94.04 & 93.84 \\
\hline O_F_Cl & 0.04 & 0.00 & 0.03 & 0.06 & 0.03 & 0.02 & 0.00 & 0.00 & 0.02 & 0.00 & 0.03 & 0.02 & O_F_Cl & 0.000 & 0.040 & 0.050 & 0.040 & 0.050 & 0.000 & 0.020 \\
\hline Si & 6.151 & 6.166 & 6.209 & 6.199 & 6.164 & 6.206 & 6.147 & 6.182 & 6.218 & 6.172 & 6.218 & 6.204 & Si & 6.195 & 6.195 & 6.210 & 6.201 & 6.178 & 6.193 & 6.212 \\
\hline $\mathrm{Al}^{\mathrm{IV}}$ & 1.849 & 1.834 & 1.791 & 1.801 & 1.836 & 1.794 & 1.853 & 1.818 & 1.782 & 1.828 & 1.782 & 1.796 & $\mathrm{Al}^{\mathrm{IV}}$ & 1.805 & 1.805 & 1.790 & 1.799 & 1.822 & 1.807 & 1.788 \\
\hline$A I^{V I}$ & 3.697 & 3.713 & 3.729 & 3.699 & 3.704 & 3.700 & 3.714 & 3.676 & 3.696 & 3.734 & 3.694 & 3.695 & $\mathrm{Al}^{\mathrm{VI}}$ & 3.645 & 3.621 & 3.580 & 3.664 & 3.620 & 3.600 & 3.577 \\
\hline $\mathrm{Ti}$ & 0.097 & 0.090 & 0.058 & 0.080 & 0.079 & 0.088 & 0.069 & 0.092 & 0.083 & 0.088 & 0.077 & 0.087 & $\mathrm{Ti}$ & 0.016 & 0.034 & 0.037 & 0.012 & 0.034 & 0.033 & 0.035 \\
\hline $\mathrm{Fe}^{2+}$ & 0.163 & 0.130 & 0.127 & 0.136 & 0.137 & 0.154 & 0.158 & 0.154 & 0.147 & 0.142 & 0.167 & 0.150 & $\mathrm{Fe}^{2+}$ & 0.249 & 0.234 & 0.233 & 0.214 & 0.238 & 0.251 & 0.266 \\
\hline Mn & 0.002 & 0.000 & 0.000 & 0.000 & 0.003 & 0.001 & 0.002 & 0.002 & 0.000 & 0.000 & 0.000 & 0.000 & $\mathrm{Cr}$ & 0.002 & 0.000 & 0.001 & 0.004 & 0.001 & 0.004 & 0.000 \\
\hline Mg & 0.108 & 0.130 & 0.127 & 0.132 & 0.132 & 0.142 & 0.127 & 0.122 & 0.130 & 0.132 & 0.132 & 0.133 & Mn & 0.002 & 0.000 & 0.004 & 0.000 & 0.001 & 0.003 & 0.002 \\
\hline $\mathrm{Ca}$ & 0.000 & 0.000 & 0.000 & 0.000 & 0.000 & 0.000 & 0.000 & 0.000 & 0.000 & 0.003 & 0.000 & 0.000 & Mg & 0.200 & 0.206 & 0.228 & 0.186 & 0.194 & 0.204 & 0.219 \\
\hline $\mathrm{Na}$ & 0.144 & 0.133 & 0.128 & 0.128 & 0.141 & 0.108 & 0.139 & 0.136 & 0.131 & 0.115 & 0.134 & 0.138 & $\mathrm{Ca}$ & 0.000 & 0.008 & 0.005 & 0.000 & 0.005 & 0.002 & 0.001 \\
\hline $\mathrm{K}$ & 1.638 & 1.662 & 1.692 & 1.677 & 1.681 & 1.601 & 1.677 & 1.688 & 1.640 & 1.561 & 1.630 & 1.622 & $\mathrm{Na}$ & 0.147 & 0.157 & 0.134 & 0.146 & 0.146 & 0.147 & 0.141 \\
\hline & & & & & & & & & & & & & $\mathrm{K}$ & 1.625 & 1.625 & 1.676 & 1.691 & 1.646 & 1.663 & 1.662 \\
\hline
\end{tabular}

Íons calculados na base de 14 cátions, $24 \mathrm{O}$. 
Tabela 7. Análises de plagioclásio usados nos cálculos de geotermobarometria.

\begin{tabular}{|c|c|c|c|c|c|c|c|c|c|c|c|c|c|c|}
\hline Análise & 110 & 112 & 113 & 115 & 116 & 122 & 129 & 132 & 137 & 139 & 254 & 255 & 256 & 258 \\
\hline $\mathrm{SiO}_{2}$ & 61.10 & 62.05 & 60.81 & 60.99 & 60.54 & 60.63 & 57.78 & 59.22 & 59.69 & 58.19 & 58.58 & 58.45 & 58.20 & 58.69 \\
\hline $\mathrm{Al}_{2} \mathrm{O}_{3}$ & 23.42 & 22.81 & 23.88 & 23.89 & 24.21 & 24.44 & 25.41 & 25.16 & 24.87 & 25.67 & 25.81 & 25.70 & 26.09 & 25.70 \\
\hline $\mathrm{TiO}_{2}$ & 0.04 & 0.22 & 0.04 & 0.01 & 0.00 & 0.01 & 0.04 & 0.00 & 0.04 & 0.01 & 0.04 & 0.00 & 0.00 & 0.00 \\
\hline $\mathrm{Fe}_{2} \mathrm{O}_{3}$ & 0.23 & 0.34 & 0.34 & 0.20 & 0.62 & 0.12 & 0.92 & 0.07 & 0.21 & 0.32 & 0.05 & 0.17 & 0.27 & 0.12 \\
\hline MnO & 0.03 & 0.01 & 0.01 & 0.00 & 0.04 & 0.01 & 0.02 & 0.01 & 0.00 & 0.00 & 0.00 & 0.01 & 0.01 & 0.00 \\
\hline MgO & 0.01 & 0.01 & 0.01 & 0.00 & 0.03 & 0.01 & 0.34 & 0.00 & 0.00 & 0.00 & 0.01 & 0.00 & 0.00 & 0.00 \\
\hline $\mathrm{CaO}$ & 5.35 & 4.48 & 5.75 & 5.71 & 6.04 & 6.21 & 7.76 & 7.10 & 6.86 & 7.78 & 7.64 & 7.53 & 7.80 & 7.47 \\
\hline $\mathrm{Na}_{2} \mathrm{O}$ & 8.26 & 8.78 & 8.11 & 8.12 & 7.87 & 7.75 & 6.56 & 7.38 & 7.53 & 6.86 & 6.97 & 7.14 & 7.01 & 7.21 \\
\hline $\mathrm{K}_{2} \mathrm{O}$ & 0.07 & 0.09 & 0.06 & 0.07 & 0.06 & 0.06 & 0.29 & 0.17 & 0.07 & 0.08 & 0.05 & 0.06 & 0.05 & 0.06 \\
\hline $\mathrm{BaO}$ & 0.05 & 0.00 & 0.00 & 0.11 & 0.00 & 0.00 & 0.00 & 0.07 & 0.00 & 0.00 & 0.00 & 0.00 & 0.00 & 0.00 \\
\hline Total & 98.55 & 98.77 & 99.00 & 99.08 & 99.40 & 99.23 & 99.11 & 99.17 & 99.26 & 98.90 & 99.26 & 99.16 & 99.58 & 99.33 \\
\hline Si & 10.999 & 11.122 & 10.910 & 10.931 & 10.835 & 10.849 & 10.448 & 10.651 & 10.710 & 10.510 & 10.534 & 10.530 & 10.456 & 10.549 \\
\hline Al & 4.964 & 4.815 & 5.046 & 5.043 & 5.102 & 5.149 & 5.412 & 5.330 & 5.255 & 5.460 & 5.465 & 5.453 & 5.520 & 5.439 \\
\hline $\mathrm{Fe}^{3+}$ & 0.031 & 0.046 & 0.046 & 0.026 & 0.083 & 0.015 & 0.124 & 0.009 & 0.028 & 0.044 & 0.007 & 0.023 & 0.037 & 0.016 \\
\hline $\mathrm{Ti}$ & 0.005 & 0.030 & 0.006 & 0.002 & 0.000 & 0.001 & 0.005 & 0.000 & 0.006 & 0.001 & 0.005 & 0.000 & 0.000 & 0.000 \\
\hline Mn & 0.004 & 0.001 & 0.002 & 0.000 & 0.005 & 0.002 & 0.003 & 0.002 & 0.000 & 0.000 & 0.000 & 0.000 & 0.000 & 0.000 \\
\hline Mg & 0.004 & 0.001 & 0.002 & 0.000 & 0.005 & 0.002 & 0.091 & 0.000 & 0.000 & 0.001 & 0.000 & 0.000 & 0.000 & 0.000 \\
\hline $\mathrm{Ba}$ & 0.003 & 0.000 & 0.000 & 0.007 & 0.000 & 0.000 & 0.000 & 0.005 & 0.000 & 0.000 & 0.000 & 0.000 & 0.000 & 0.000 \\
\hline $\mathrm{Ca}$ & 1.032 & 0.860 & 1.104 & 1.096 & 1.158 & 1.190 & 1.504 & 1.368 & 1.318 & 1.505 & 1.473 & 1.454 & 1.501 & 1.438 \\
\hline $\mathrm{Na}$ & 2.884 & 3.050 & 2.820 & 2.822 & 2.731 & 2.688 & 2.299 & 2.573 & 2.620 & 2.402 & 2.429 & 2.492 & 2.443 & 2.513 \\
\hline $\mathrm{K}$ & 0.015 & 0.021 & 0.014 & 0.015 & 0.013 & 0.014 & 0.066 & 0.039 & 0.016 & 0.018 & 0.011 & 0.013 & 0.011 & 0.013 \\
\hline$A b$ & 73.400 & 77.600 & 71.600 & 71.800 & 70.000 & 69.100 & 59.400 & 64.600 & 66.300 & 61.200 & 62.100 & 62.900 & 61.800 & 63.400 \\
\hline $\mathrm{Na}$ & 26.300 & 21.900 & 28.000 & 27.900 & 29.700 & 30.600 & 38.900 & 34.400 & 33.300 & 38.300 & 37.600 & 36.700 & 38.000 & 36.300 \\
\hline Or & 0.400 & 0.500 & 0.400 & 0.400 & 0.300 & 0.400 & 1.700 & 1.000 & 0.400 & 0.500 & 0.300 & 0.300 & 0.300 & 0.300 \\
\hline
\end{tabular}

Íns calculados na base de 20 cátions, 320 . 
Tabela 8. Análises de clorita e cloritóide usados nos cálculos de geotermobarometria.

\begin{tabular}{|c|c|c|c|c|c|c|c|c|c|c|c|c|c|c|c|c|c|c|c|}
\hline \multicolumn{11}{|c|}{ CLORITA } & \multicolumn{9}{|c|}{ CLORITOIDE } \\
\hline Análise & 213 & 214 & 215 & 216 & 217 & 207 & 208 & 210 & 211 & 212 & 223 & 224 & 225 & 226 & 227 & 228 & 229 & 230 & 231 \\
\hline $\mathrm{SiO}_{2}$ & 23.65 & 23.66 & 23.64 & 23.48 & 23.52 & 23.86 & 24.48 & 24.49 & 24.32 & 23.94 & 24.684 & 24.734 & 24.769 & 24.729 & 24.727 & 24.465 & 24.513 & 24.518 & 25.005 \\
\hline $\mathrm{TiO}_{2}$ & 0.07 & 0.09 & 0.08 & 0.08 & 0.07 & 0.07 & 0.04 & 0.07 & 0.16 & 0.10 & .040 & 0.000 & 0.000 & 0.010 & 0.000 & 0.009 & 0.057 & 0.000 & 0.000 \\
\hline $\mathrm{Al}_{2} \mathrm{O}_{3}$ & 23.40 & 23.01 & 23.11 & 23.45 & 23.05 & 23.32 & 23.32 & 22.83 & 23.14 & 23.20 & 40.764 & 40.937 & 40.620 & 40.787 & 40.737 & 40.609 & 40.361 & 40.343 & 40.849 \\
\hline $\mathrm{FeO}$ & 26.47 & 25.69 & 26.79 & 26.64 & 26.00 & 24.82 & 24.96 & 5.19 & 24.86 & 24.64 & 23.449 & 22.886 & 23.225 & 23.077 & 23.286 & 23.046 & 23.407 & 3.006 & 23.347 \\
\hline MnO & 0.22 & 0.24 & 0.17 & 0.22 & 0.23 & 0.19 & 0.15 & 0.16 & 0.17 & 0.10 & 0.606 & 0.598 & 0.531 & 0.596 & 0.527 & 0.575 & 0.631 & 0.580 & 0.676 \\
\hline MgO & 12.30 & 13.29 & 12.40 & 12.46 & 12.70 & 13.27 & 13.36 & 13.59 & 13.60 & 13.39 & 2.648 & 2.931 & 2.997 & 2.969 & 2.570 & 2.615 & 2.483 & 2.846 & 2.638 \\
\hline $\mathrm{CaO}$ & 0.02 & 0.03 & 0.02 & 0.02 & 0.02 & 0.02 & 0.00 & 0.01 & 0.01 & 0.01 & 0.000 & 0.006 & 0.000 & 0.015 & 0.014 & 0.004 & 0.000 & 0.013 & 0.001 \\
\hline $\mathrm{Na}_{2} \mathrm{O}$ & 0.01 & 0.00 & 0.00 & 0.00 & 0.02 & 0.01 & 0.01 & 0.01 & 0.02 & 0.00 & 0.000 & 0.002 & 0.000 & 0.000 & 0.000 & 0.009 & 0.004 & 0.000 & 0.005 \\
\hline $\mathrm{K}_{2} \mathrm{O}$ & 0.01 & 0.01 & 0.01 & 0.00 & 0.01 & 0.02 & 0.00 & 0.00 & 0.01 & 0.00 & 0.000 & 0.000 & 0.000 & 0.000 & 0.002 & 0.005 & 0.011 & 0.014 & 0.008 \\
\hline $\mathrm{Cl}$ & 0.00 & 0.00 & 0.00 & 0.01 & 0.00 & 0.00 & 0.00 & 0.00 & 0.01 & 0.01 & 0.000 & 0.000 & 0.015 & 0.014 & 0.004 & 0.000 & 0.003 & 0.000 & 0.009 \\
\hline $\mathbf{F}$ & 0.00 & 0.00 & & & & & & & & 0.00 & & & 70 & 0 & 30 & & 16 & 0 & .000 \\
\hline $\mathrm{BaO}$ & 0.00 & 0.00 & 0.00 & 0.03 & 0.00 & 0.02 & 0.00 & 0.00 & 0.00 & 0.00 & 0.030 & 0.011 & 0.008 & 0.000 & 0.000 & 0.073 & 0.042 & 0.000 & 0.000 \\
\hline Total & 86.15 & 86.03 & 86.22 & 86.44 & 85.60 & 85.68 & 80.32 & 86.38 & 86.30 & 85.40 & 92.220 & 92.100 & 92.240 & 92.200 & 91.950 & 91.410 & 91.530 & 91.320 & 92.540 \\
\hline O_F_Cl & 0.00 & 0.00 & 0.00 & 0.02 & 0.00 & 0.03 & 0.00 & 0.01 & 0.00 & 0.00 & 0.000 & 0.000 & 0.030 & 0.000 & 0.030 & 0.000 & 0.010 & 0.000 & 0.000 \\
\hline Si & 5.114 & 5.108 & 5.119 & 5.072 & 5.112 & 5.146 & 5.225 & 5.237 & 5.196 & 5.168 & 4.747 & 4.747 & 4.760 & 4.748 & 4.766 & 4.742 & 4.756 & 4.755 & 4.786 \\
\hline$A I^{\prime v}$ & 2.886 & 2.892 & 2.881 & 2.928 & 2.888 & 2.854 & 2.775 & 2.763 & 2.804 & 2.832 & 3.253 & 3.253 & 3.240 & 3.252 & 3.234 & 3.258 & 3.244 & 3.245 & 3.214 \\
\hline$A I^{v 1}$ & 3.073 & 2.960 & 3.011 & 3.037 & 3.012 & 3.070 & 3.087 & 2.987 & 3.019 & 3.065 & 5.979 & 6.000 & 5.952 & 5.970 & 6.014 & 6.012 & 5.978 & 5.969 & 5.994 \\
\hline $\mathrm{Ti}$ & 0.011 & 0.014 & 0.013 & 0.013 & 0.012 & 0.011 & 0.007 & 0.011 & 0.026 & 0.016 & 0.006 & 0.000 & 0.000 & 0.001 & 0.000 & 0.001 & 0.008 & 0.000 & 0.000 \\
\hline $\mathrm{Fe}^{2+}$ & 4.786 & 4.639 & 4.850 & 4.812 & 4.727 & 4.478 & 4.455 & 4.504 & 4.443 & 4.448 & 3.771 & 3.674 & 3.732 & 3.705 & 3.754 & 3.736 & 3.798 & 3.732 & 3.737 \\
\hline Mn & 0.040 & 0.043 & 0.031 & 0.040 & 0.042 & 0.035 & 0.026 & 0.029 & 0.031 & 0.019 & 0.099 & 0.097 & 0.086 & 0.097 & 0.086 & 0.094 & 0.104 & 0.095 & 0.110 \\
\hline Mg & 3.965 & 4.278 & 4.002 & 4.013 & 4.117 & 4.268 & 4.252 & 4.334 & 4.332 & 4.309 & 0.759 & 0.839 & 0.859 & 0.850 & 0.739 & 0.756 & 0.718 & 0.823 & 0.753 \\
\hline $\mathrm{Ca}$ & 0.006 & 0.007 & 0.005 & 0.004 & 0.004 & 0.005 & 0.001 & 0.002 & 0.002 & 0.002 & 0.000 & 0.001 & 0.000 & 0.003 & 0.003 & 0.001 & 0.000 & 0.003 & 0.000 \\
\hline $\mathrm{Na}$ & 0.003 & 0.000 & 0.000 & 0.002 & 0.006 & 0.005 & 0.002 & 0.002 & 0.010 & 0.000 & 0.000 & 0.001 & 0.000 & 0.000 & 0.000 & 0.003 & 0.002 & 0.000 & 0.002 \\
\hline$K$ & 0.002 & 0.003 & 0.003 & 0.000 & 0.002 & 0.005 & 0.000 & 0.000 & 0.003 & 0.000 & 0.000 & 0.000 & 0.000 & 0.000 & 0.000 & 0.001 & 0.003 & 0.003 & 0.002 \\
\hline
\end{tabular}

Íons calculados na base de 16 cátions, 220. 
Tabela 9. Análises de estaurolita usados nos cálculos de geotermobarometria.

\begin{tabular}{|c|c|c|c|c|c|}
\hline Análise & 248 & 249 & 250 & 251 & 252 \\
\hline $\mathrm{SiO}_{2}$ & 27.79 & 27.46 & 27.37 & 27.54 & 27.80 \\
\hline $\mathrm{TiO}_{2}$ & 0.53 & 0.40 & 0.62 & 0.49 & 0.45 \\
\hline $\mathrm{Al}_{2} \mathrm{O}_{3}$ & 54.30 & 54.17 & 54.06 & 54.80 & 53.93 \\
\hline $\mathrm{FeO}$ & 12.64 & 12.87 & 12.94 & 12.56 & 12.12 \\
\hline MnO & 0.27 & 0.26 & 0.24 & 0.23 & 0.21 \\
\hline MgO & 1.33 & 1.41 & 1.40 & 1.37 & 1.31 \\
\hline $\mathrm{CaO}$ & 0.00 & 0.00 & 0.00 & 0.00 & 0.01 \\
\hline $\mathrm{Na}_{2} \mathrm{O}$ & 0.00 & 0.02 & 0.00 & 0.01 & 0.01 \\
\hline $\mathrm{K}_{2} \mathrm{O}$ & 0.01 & 0.01 & 0.00 & 0.01 & 0.01 \\
\hline$F$ & 0.04 & 0.01 & 0.00 & 0.08 & 0.09 \\
\hline Zno & 0.19 & 0.16 & 0.17 & 0.22 & 0.26 \\
\hline Total & 97.11 & 96.78 & 96.79 & 97.30 & 96.18 \\
\hline Si & 3.866 & 3.839 & 3.827 & 3.824 & 3.896 \\
\hline Al & 8.896 & 8.917 & 8.901 & 8.961 & 8.902 \\
\hline $\mathrm{Ti}$ & 0.055 & 0.042 & 0.065 & 0.051 & 0.047 \\
\hline $\mathrm{Fe}^{2+}$ & 1.471 & 1.504 & 1.514 & 1.458 & 1.420 \\
\hline Mn & 0.032 & 0.031 & 0.028 & 0.027 & 0.025 \\
\hline Mg & 0.277 & 0.294 & 0.292 & 0.284 & 0.273 \\
\hline $\mathrm{Ca}$ & 0.000 & 0.000 & 0.000 & 0.000 & 0.001 \\
\hline $\mathrm{Na}$ & 0.000 & 0.005 & 0.000 & 0.003 & 0.002 \\
\hline K & 0.002 & 0.002 & 0.000 & 0.002 & 0.002 \\
\hline
\end{tabular}

Ions calculados na base de 16 cátions, $24 \mathrm{O}$. 


\section{ANEXO III}

Tabelas mostrando as associações e respectivas análises usadas nos cálculos termobarométricos realizados utilizando-se o software TWQ. 
Nas tabelas (Grt) granada, (Amp) anfibólio, (PI) plagioclásio, (Ms) muscovita e (Bt) biotita.

\begin{tabular}{|c|c|c|c|c|c|c|c|c|}
\hline \multicolumn{3}{|c|}{ Amostra 11c } & \multicolumn{3}{|c|}{ Amostra 12c } & \multicolumn{3}{|l|}{ Amostra 46} \\
\hline Análises & Associações & Localização & Análises & Associações & Localização & Análises & Associações & Localização \\
\hline $17 / 89$ & Grt - Amp & Bordas & $54 / 101$ & Grt - Amp & Bordas & $254 / 187 / 234 / 480$ & $\mathrm{Pl}-\mathrm{Grt}-\mathrm{Bt}-\mathrm{Ms}$ & Núcleos \\
\hline $21 / 89$ & Grt - Amp & Bordas & $54 / 102$ & Grt - Amp & Bordas & $254 / 187 / 234 / 463$ & $\mathrm{Pl}-\mathrm{Grt}-\mathrm{Bt}-\mathrm{Ms}$ & Núcleos \\
\hline $12 / 66$ & Grt - Amp & Núcleos & $60 / 101$ & Grt - Amp & Bordas & $258 / 187 / 234 / 480$ & $\mathrm{PI}-\mathrm{Grt}-\mathrm{Bt}-\mathrm{Ms}$ & Núcleos \\
\hline $7 / 67$ & Grt - Amp & Bordas & $60 / 102$ & Grt - Amp & Bordas & $254 / 187 / 234 / 463$ & $\mathrm{PI}-\mathrm{Grt}-\mathrm{Bt}-\mathrm{Ms}$ & Núcleos \\
\hline $1 / 65$ & Grt - Amp & Bordas & $132 / 59 / 101$ & PI - Grt - Amp & Núcleos & $258 / 187 / 234 / 476$ & $\mathrm{PI}-\mathrm{Grt}-\mathrm{Bt}-\mathrm{Ms}$ & Núcleos \\
\hline $16 / 89$ & Grt - Amp & Núcleos & $129 / 54 / 101$ & PI - Grt - Amp & Bordas & $255 / 184 / 236 / 472$ & $\mathrm{PI}-\mathrm{Grt}-\mathrm{Bt}-\mathrm{Ms}$ & Bordas \\
\hline $20 / 91$ & Grt - Amp & Núcleos & $139 / 54 / 101$ & PI - Grt - Amp & Bordas & $255 / 184 / 236 / 475$ & $\mathrm{PI}-\mathrm{Grt}-\mathrm{Bt}-\mathrm{Ms}$ & Bordas \\
\hline $15 / 88$ & Grt - Amp & Bordas & $137 / 54 / 101$ & PI - Grt - Amp & Bordas & $255 / 184 / 236 / 477$ & $\mathrm{PI}-\mathrm{Grt}-\mathrm{Bt}-\mathrm{Ms}$ & Bordas \\
\hline $15 / 90$ & Grt - Amp & Bordas & $129 / 54 / 102$ & PI - Grt - Amp & Bordas & $256 / 184 / 236 / 472$ & $\mathrm{PI}-\mathrm{Grt}-\mathrm{Bt}-\mathrm{Ms}$ & Bordas \\
\hline $15 / 89$ & Grt - Amp & Bordas & $139 / 54 / 102$ & PI - Grt - Amp & Bordas & $256 / 184 / 236 / 475$ & $\mathrm{PI}-\mathrm{Grt}-\mathrm{Bt}-\mathrm{Ms}$ & Bordas \\
\hline $18 / 91$ & Grt - Amp & Bordas & $137 / 54 / 102$ & PI - Grt - Amp & Bordas & $256 / 184 / 236 / 477$ & $\mathrm{PI}-\mathrm{Grt}-\mathrm{Bt}-\mathrm{Ms}$ & Bordas \\
\hline $18 / 89$ & Grt - Amp & Bordas & $129 / 60 / 102$ & PI - Grt - Amp & Bordas & & & \\
\hline $16 / 90$ & Grt - Amp & Núcleos & $139 / 60 / 102$ & PI - Grt - Amp & Bordas & & & \\
\hline $7 / 65$ & Grt - Amp & Bordas & $137 / 60 / 102$ & PI - Grt - Amp & Bordas & & & \\
\hline $14 / 65$ & Grt - Amp & Bordas & $129 / 60 / 101$ & PI - Grt - Amp & Bordas & & & \\
\hline $14 / 67$ & Grt - Amp & Bordas & $139 / 60 / 101$ & PI - Grt - Amp & Bordas & & & \\
\hline $1 / 67$ & Grt - Amp & Bordas & $137 / 60 / 101$ & PI - Grt - Amp & Bordas & & & \\
\hline $3 / 66$ & Grt - Amp & Núcleos & & & & & & \\
\hline $26 / 94$ & Grt - Amp & Bordas & & & & & & \\
\hline $23 / 94$ & Grt - Amp & Bordas & & & & & & \\
\hline 29/95 & Grt - Amp & Núcleos & & & & & & \\
\hline $122 / 59 / 104$ & PI - Grt - Amp & Inclusiones en Grt & & & & & & \\
\hline $27 / 89$ & Grt - Amp & Intermedios & & & & & & \\
\hline $28 / 89$ & Grt - Amp & Intermedios & & & & & & \\
\hline $30 / 89$ & Grt - Amp & Intermedios & & & & & & \\
\hline $31 / 89$ & Grt - Amp & Intermedios & & & & & & \\
\hline
\end{tabular}




\begin{tabular}{|c|c|c|c|c|c|c|c|c|}
\hline \multicolumn{3}{|c|}{ Amostra 20b } & \multicolumn{3}{|l|}{ Amostra 20b } & & & \\
\hline Análises & Associações & Localização & Análises & Associações & Localização & & & \\
\hline $116 / 36 / 68$ & PI - Grt - Amp & Bordas & $112 / 36 / 82$ & PI - Grt - Amp & Bordas & & & \\
\hline $116 / 32 / 68$ & PI - Grt - Amp & Bordas & $112 / 51 / 82$ & PI - Grt - Amp & Bordas & & & \\
\hline $116 / 51 / 68$ & PI - Grt - Amp & Bordas & $112 / 46 / 82$ & Pl - Grt - Amp & Bordas & & & \\
\hline $116 / 46 / 68$ & PI - Grt - Amp & Bordas & $113 / 32 / 82$ & PI - Grt - Amp & Bordas & & & \\
\hline $116 / 36 / 70$ & PI - Grt - Amp & Bordas & $113 / 36 / 82$ & PI - Grt - Amp & Bordas & & & \\
\hline $116 / 32 / 70$ & PI - Grt - Amp & Bordas & $113 / 51 / 82$ & PI - Grt - Amp & Bordas & & & \\
\hline $116 / 51 / 70$ & PI - Grt - Amp & Bordas & $113 / 46 / 82$ & PI - Grt - Amp & Bordas & & & \\
\hline $116 / 46 / 70$ & PI - Grt - Amp & Bordas & $115 / 34 / 74$ & PI - Grt - Amp & Núcleos & & & \\
\hline $112 / 36 / 68$ & PI - Grt - Amp & Bordas & $115 / 34 / 79$ & PI - Grt - Amp & Núcleos & & & \\
\hline $112 / 32 / 68$ & PI - Grt - Amp & Bordas & $110 / 34 / 74$ & PI - Grt - Amp & Núcleos & & & \\
\hline $112 / 51 / 68$ & PI - Grt - Amp & Bordas & $110 / 34 / 79$ & PI - Grt - Amp & Núcleos & & & \\
\hline $112 / 46 / 68$ & PI - Grt - Amp & Bordas & $110 / 34 / 85$ & Pl - Grt - Amp & Núcleos & & & \\
\hline $112 / 36 / 70$ & PI - Grt - Amp & Bordas & $34 / 85$ & Grt - Amp & Núcleos & & & \\
\hline $112 / 32 / 70$ & PI - Grt - Amp & Bordas & $34 / 74$ & Grt - Amp & Núcleos & & & \\
\hline $112 / 51 / 70$ & Pl - Grt - Amp & Bordas & $34 / 79$ & Grt - Amp & Núcleos & & & \\
\hline $112 / 46 / 70$ & PI - Grt - Amp & Bordas & & & & & & \\
\hline $113 / 36 / 88$ & PI - Grt - Amp & Bordas & Amostra 53 & & & Amostra 53 & & \\
\hline $113 / 32 / 68$ & PI - Grt - Amp & Bordas & Análises & Associações & Localização & Análises & Associações & Localização \\
\hline $113 / 51 / 68$ & PI - Grt - Amp & Bordas & $305 / 411 / 422$ & Grt - Bt - Ms & Núcleos & $373 / 393 / 421$ & Grt - Bt - Ms & Bordas \\
\hline $113 / 46 / 68$ & Pl - Grt - Amp & Bordas & $305 / 394 / 422$ & Grt - Bt - Ms & Núcleos & $374 / 401 / 421$ & Grt - Bt - Ms & Bordas \\
\hline $113 / 36 / 70$ & Pl - Grt - Amp & Bordas & $305 / 390 / 422$ & Grt - Bt - Ms & Núcleos & $375 / 403 / 421$ & Grt - Bt - Ms & Bordas \\
\hline $113 / 32 / 70$ & PI - Grt - Amp & Bordas & $381 / 411 / 422$ & Grt - Bt - Ms & Núcleos & $371 / 389 / 421$ & Grt - Bt - Ms & Bordas \\
\hline $113 / 51 / 70$ & PI - Grt - Amp & Bordas & $381 / 394 / 422$ & Grt - Bt - Ms & Núcleos & $381 / 406 / 430$ & Grt - Bt - Ms & Núcleos* \\
\hline $113 / 46 / 70$ & PI - Grt - Amp & Bordas & 381/390/422 & Grt - Bt - Ms & Núcleos & $364 / 397 / 426$ & Grt - Bt - Ms & Núcleos* \\
\hline $116 / 36 / 77$ & Pl - Grt - Amp & Bordas & $364 / 411 / 422$ & Grt - Bt - Ms & Núcleos & $364 / 396 / 428$ & Grt - Bt - Ms & Bordas* \\
\hline $116 / 32 / 77$ & PI - Grt - Amp & Bordas & $364 / 394 / 422$ & Grt - Bt - Ms & Núcleos & $381 / 408 / 449$ & Grt - Bt - Ms & Bordas* \\
\hline $116 / 51 / 77$ & PI - Grt - Amp & Bordas & $364 / 390 / 422$ & Grt - Bt - Ms & Núcleos & $378 / 407 / 448$ & $\mathrm{Grt}-\mathrm{Bt}-\mathrm{Ms}$ & Bordas* \\
\hline $116 / 46 / 77$ & PI - Grt - Amp & Bordas & $310 / 413 / 456$ & Grt - Bt - Ms & Bordas & ${ }^{*}$ Biotita e Mu & ita inclusas na & nada. \\
\hline $112 / 36 / 77$ & PI - Grt - Amp & Bordas & $310 / 414 / 458$ & Grt - Bt - Ms & Bordas & & & \\
\hline $112 / 32 / 77$ & PI - Grt - Amp & Bordas & 310/415/455 & Grt - Bt - Ms & Bordas & & & \\
\hline $112 / 51 / 77$ & PI - Grt - Amp & Bordas & $313 / 413 / 456$ & Grt - Bt - Ms & Bordas & & & \\
\hline $112 / 46 / 77$ & PI - Grt - Amp & Bordas & $313 / 414 / 458$ & Grt - Bt - Ms & Bordas & & & \\
\hline $113 / 36 / 77$ & Pl - Grt - Amp & Bordas & $313 / 415 / 455$ & Grt - Bt - Ms & Bordas & & & \\
\hline $113 / 32 / 77$ & PI - Grt - Amp & Bordas & $376 / 412 / 450$ & Grt - Bt - Ms & Bordas & & & \\
\hline $113 / 51 / 77$ & PI - Grt - Amp & Bordas & $386 / 412 / 450$ & Grt - Bt - Ms & Bordas & & & \\
\hline $113 / 46 / 77$ & PI - Grt - Amp & Bordas & $387 / 412 / 450$ & Grt - Bt - Ms & Bordas & & & \\
\hline $116 / 32 / 82$ & PI - Grt - Amp & Bordas & $376 / 410 / 454$ & Grt - Bt - Ms & Bordas & & & \\
\hline $116 / 36 / 82$ & PI - Grt - Amp & Bordas & $386 / 410 / 454$ & Grt - Bt - Ms & Bordas & & & \\
\hline $116 / 51 / 82$ & PI - Grt - Amp & Bordas & 387/410/454 & Grt - Bt - Ms & Bordas & & & \\
\hline $116 / 46 / 82$ & Pl - Grt - Amp & Bordas & $357 / 388 / 421$ & Grt - Bt - Ms & Bordas & & & \\
\hline $112 / 32 / 82$ & Pl - Grt - Amp & Bordas & $372 / 392 / 421$ & Grt - Bt - Ms & Bordas & & & \\
\hline
\end{tabular}

